Page 1 of (.............. Proj.

\begin{tabular}{|c|c|c|c|c|}
\hline \multirow{3}{*}{$\begin{array}{l}\text { 2. ECN Category } \\
\text { (mark one) } \\
\text { Supplemental } \\
\text { Direct Revision } \\
\text { Change ECN } \\
\text { Temporary } \\
\text { Standby } \\
\text { Supersedure } \\
\text { Cancel/Void }\end{array}$} & \multirow{3}{*}{$\begin{array}{c}{[]} \\
{[x]} \\
{[]} \\
{[]} \\
{[]} \\
{[]} \\
{[]}\end{array}$} & $\begin{array}{l}\text { 3. Originator's Name, Organization, MSIN, } \\
\text { and Telephone No. } \\
\text { S. F. Kessler, Nuclear Safety, R3-26 } \\
\text { 376-2768 }\end{array}$ & $\begin{array}{l}\text { 4. USQ Required? } \\
\text { [ ] Yes [x] No }\end{array}$ & $10 / 11 / 99$ \\
\hline & & $\begin{array}{l}\text { 6. Project Title/No./Work Order No. } \\
\text { Spent Nuclear Fuel Project }\end{array}$ & $\begin{array}{l}\text { 7. Bidg./Sys./Fac. No. } \\
\text { SNF }\end{array}$ & $\begin{array}{l}\text { 8. Approval Designator } \\
\qquad \mathrm{S}^{\mathrm{N}}\end{array}$ \\
\hline & & $\begin{array}{l}\text { 9. Document Numbers Changed by this ECN } \\
\text { (includes sheet no. and rev.) } \\
\text { HNF-SD-SNF-CSER-005, Rev. }\end{array}$ & $\begin{array}{l}\text { 10. Related ECN No(s). } \\
647502\end{array}$ & $\begin{array}{l}\text { 11. Related PO No. } \\
\text { N/A }\end{array}$ \\
\hline
\end{tabular}

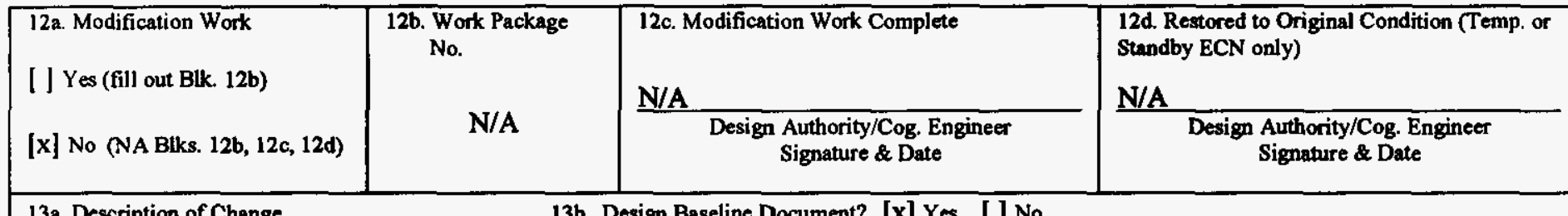

13a. Description of Change 13b. Design Baseline Document? [x] Yes [] No

This report was revised to incorporate analyses performed in response to review comments for the CVD and CSB FSARs.

No USQ required because this ECN doesn't change the facility or its procedures.

\begin{tabular}{llllllll}
\hline 14a. Justification (mark one) & & & & & \\
Criteria Change & [ ] & Design Improvement & [x] & Environmental & [ ] & Facility Deactivation \\
As-Found & [ ] & Facilitate Const & [] & Const. Error/Omission & [] & Design Error/Omission & [ ] \\
\hline
\end{tabular}

14b. Justification Details

Both the MCO and the fuel and scrap basket designs were changed and new criticality analyses were required to demonstrate acceptability.

I5. Distribution (include name, MSIN, and no. of copies)

See attached distribution coversheet. 


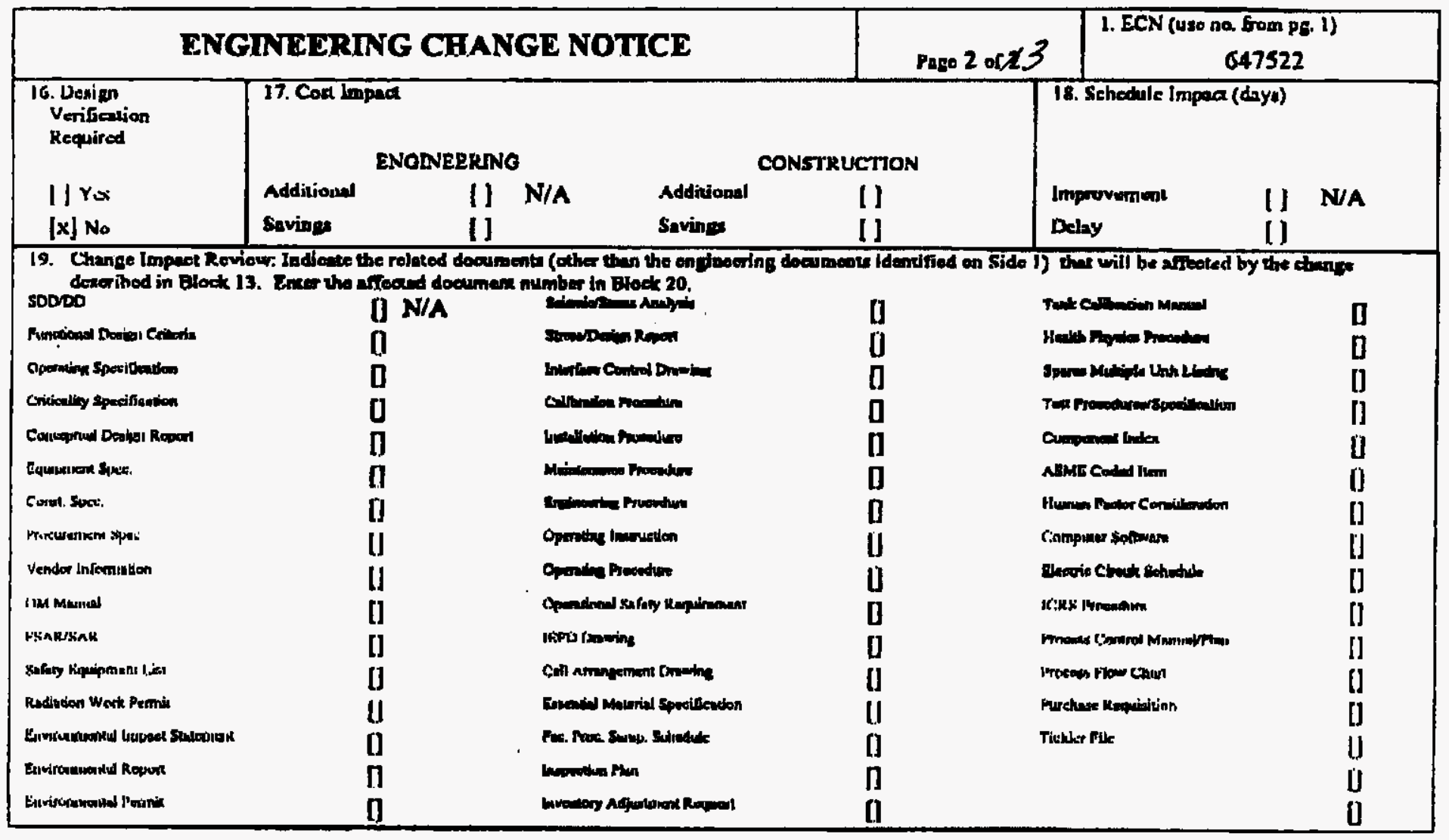

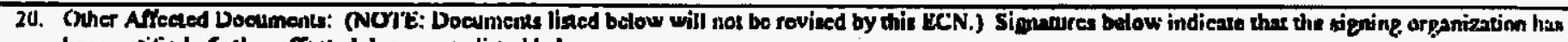
boun notilited of uhat affected docaments lixed below. Doeumene Number/Rovision

Documens Numbor/Revlaion

N/A
Document Numbur Rovixion

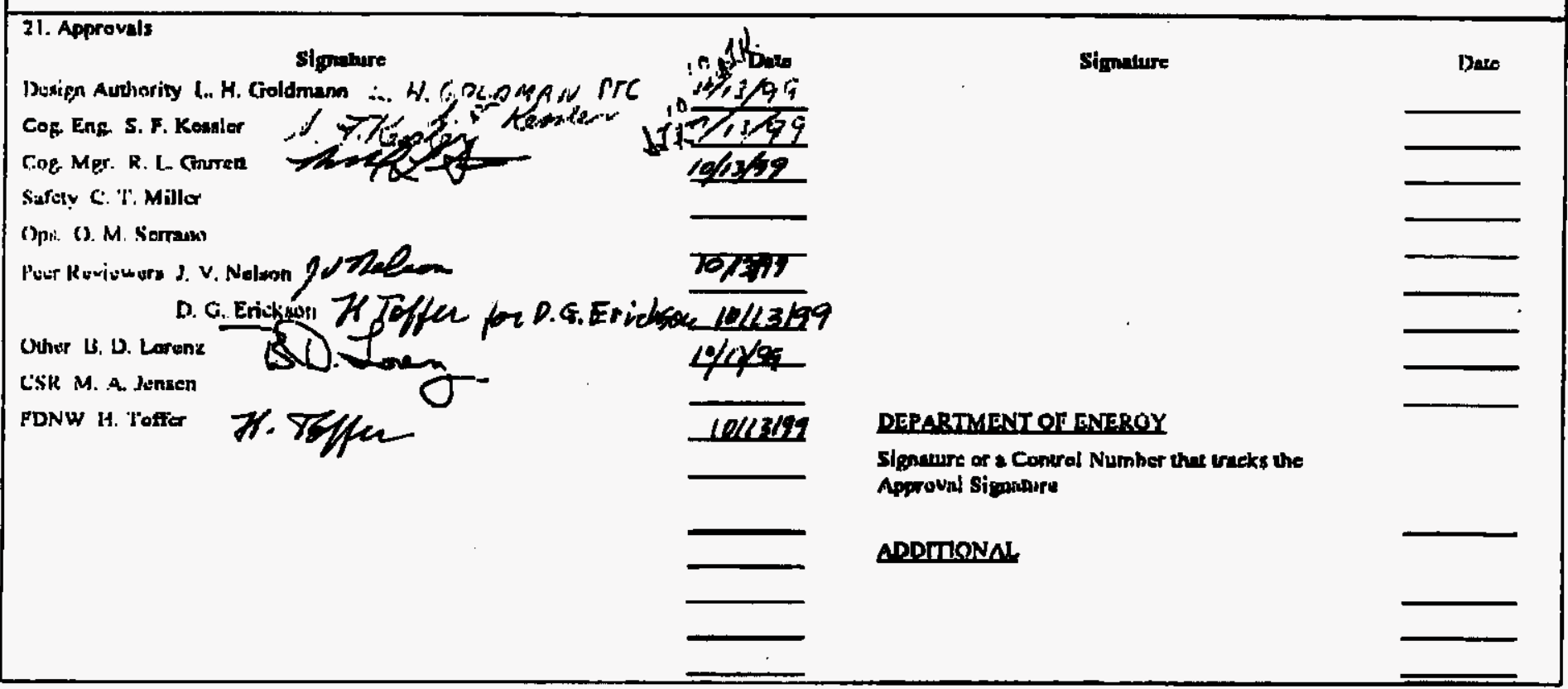




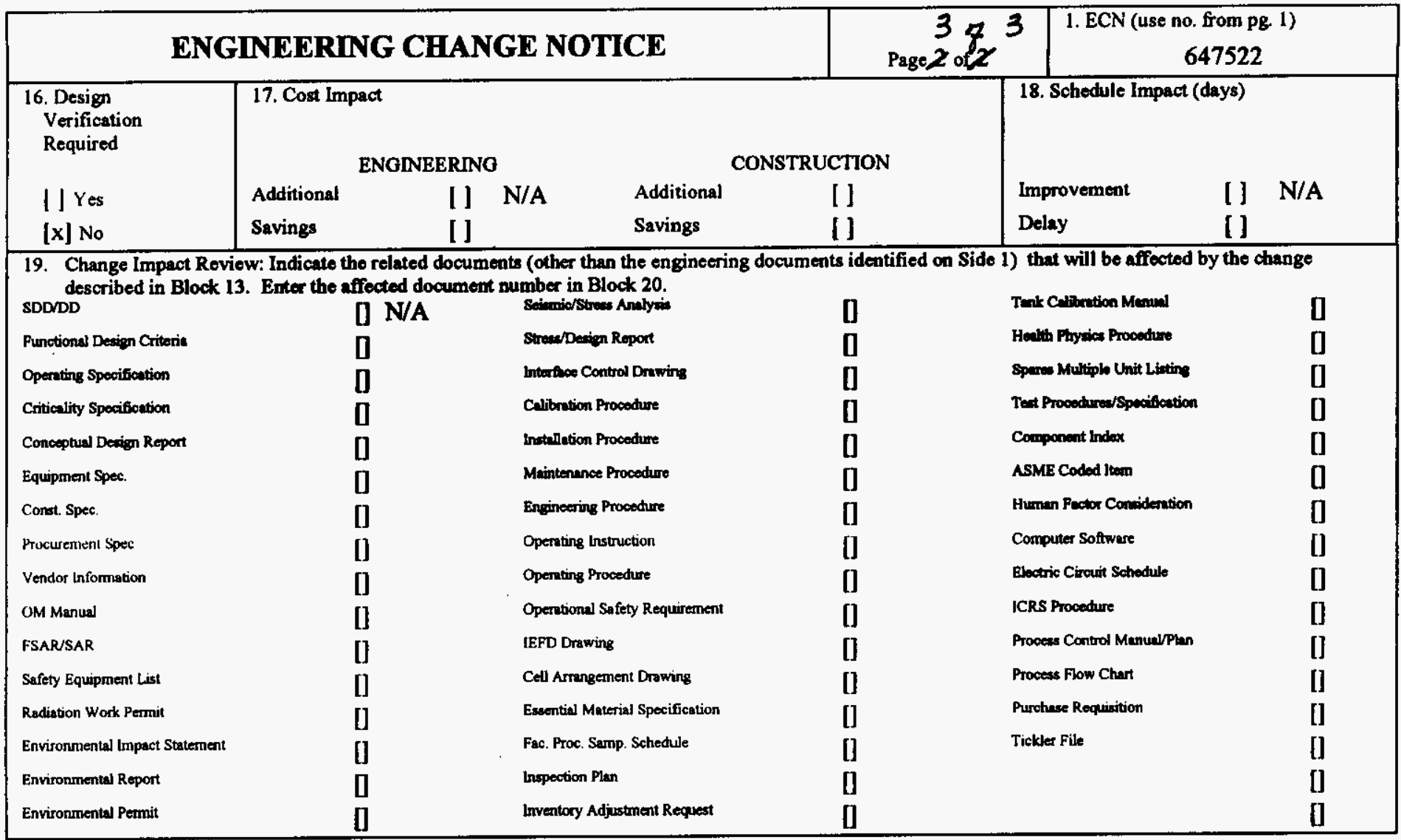

20. Other Affected Documents: (NOTE: Documents listed below will not be revised by this ECN.) Signatures below indicate that the signing organization has been notified of other affected documents listed below. Document Number/Revision

$$
\text { Signature }
$$

Design Authority 4 PTC 10 Date

Cog. Eng. S. F. Kessler

Cog. Mgr. R. L. Garrett

Safety C. T. Miller CT MILLER PTC A.T. hesslen

Ops. O.M. Serrano O.M. SERR AND PTC J.J-Tessla

Peer Reviewers J. V. Nelson OJThen

$$
\text { D. G. Erickson }
$$

Other B. D. Lorenz

CSR M. A. Jensen

FDNW H. Toffer

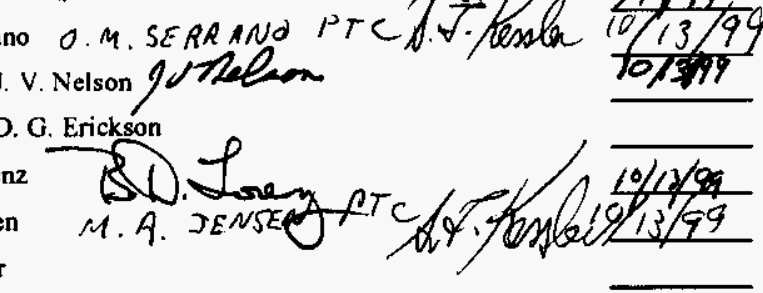

Signature

Date

\section{DEPARTMENT OF ENERGY}

Signature or a Control Number that tracks the Approval Signature

ADDITIONAL 


\section{DISTRIBUTION SHEET}

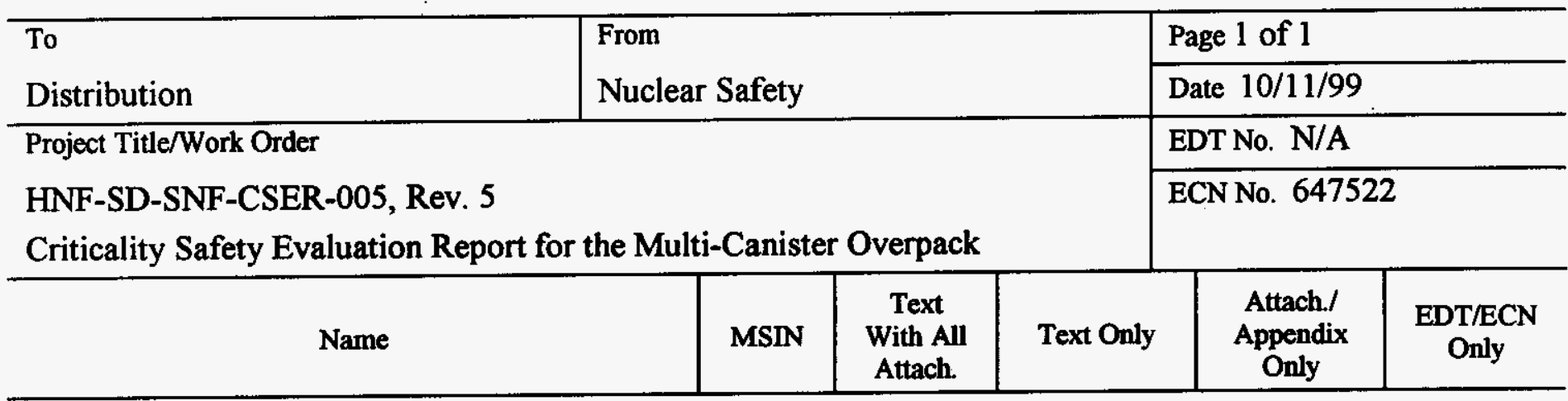

S. T. Almodovar

S. J. Altschuler

S. A. Brisbin

D. M. Chenault

R. D. Crowe

D. G. Erickson

R. L. Garrett

L. J. Garvin

L. H. Goldmann

D. R. Henry

M. A. Jensen

S. F. Kessler

B. D. Lorenz

C. T. Miller

J. V. Nelson

A. B. Rau

C. J. Ross

O. M. Serrano

K. E. Smith

SNF Project Files
A3-02 X

R3-79 X

R3-86 X

R3-86 X

R3-26 X

B4-44 $X$

R3-26 X

R3-26 X

R3-86 $X$

X3-57 X

X3-79 X

R3-26 X

R3-26 X

X3-79 X

R3-26 $X$

B4-46 X

R3-26 X

R3-86 X

L6-58 $X$

R3-11 X 


\title{
Criticality Safety Evaluation Report for the Multi-Canister Overpack
}

\author{
S. F. Kessler \\ Fluor Daniel Northwest, Inc., Richland, WA 99352 \\ U.S. Department of Energy Contract DE-AC06-96RL13200
}

ECN: 647522

Org Code: 403

UC: 940

B\&R Code: EW31354040

Charge Code: 105531/CB80

Total Pages: 182

Key Words: Low enriched spent nuclear fuel shipping container, criticality, Monte Carlo, Deterministic transport

Abstract: This criticality evaluation is for Spent $\mathrm{N}$ Reactor fuel unloaded from the existing canisters in both $\mathrm{KE}$ and KW Basins, and loaded into multiple canister overpack (MCO) containers with specially built baskets containing a maximum of either 54 Mark IV or 48 Mark IA fuel assemblies. The criticality evaluations include loading baskets into the cask-MCO, operation at the Cold Vacuum Drying Facility, and storage in the Canister Storage Building. Many conservatisms have been built into this analysis, the primary one being the selection of the $\mathrm{K}_{\text {off }}=0.95$ criticality safety limit. This revision incorporates the analyses for the sampling/weld station in the Canister Storage Building and additional analysis of the MCO during the draining at CVDF. Additional discussion of the scrap basket model was added to show why the addition of copper divider plates was not included in the models.

TRADEMARK DISCLAIMER. Reference herein to any specific commercial product, process, or service by trade name, trademark, manufacturer, or otherwise, does not necessarily constitute or imply its endorsement, recommendation, or favoring by the United States Government or any agency thereof or its contractors or subcontractors.

Printed in the United States of America. To obtain copies of this document, contact: Document Control Services, P.O. Box 950, Mailstop H6-08, Richland WA 99352, Phone (509) 372-2420; Fax (509) 376-4989.
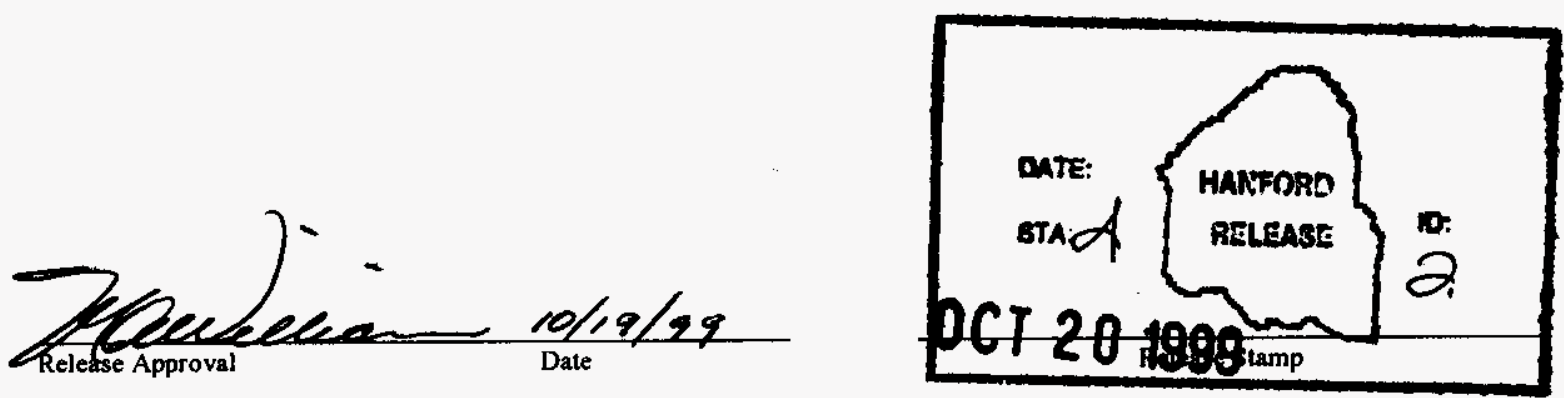


\section{RECORD OF REVISION}

(2) Title

Criticality Safety Evaluation Report for the Multi-Canister Overpack

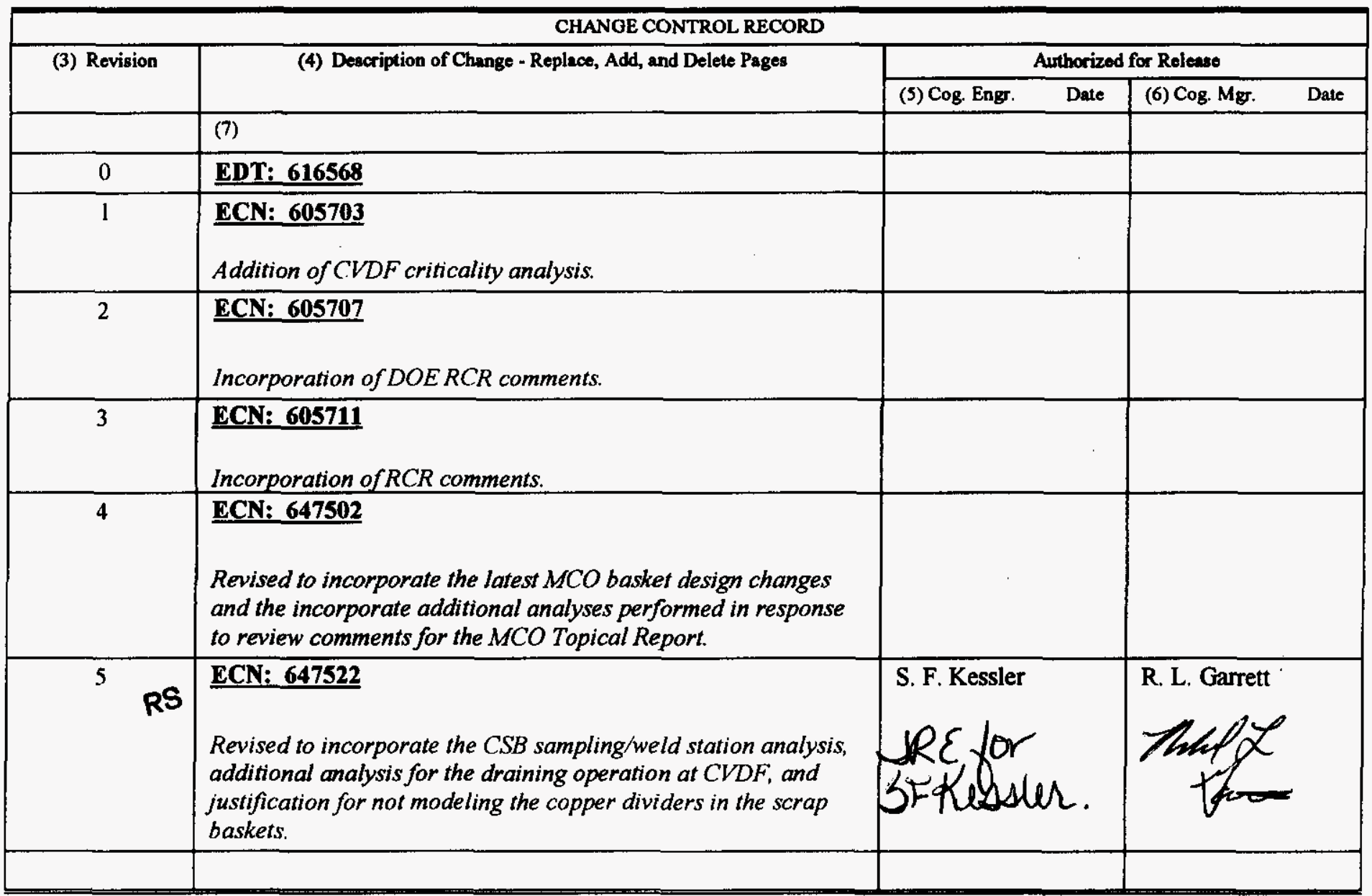

HNF-SD-SNF-CSER-005,

Rev. 5
(1) Document Number 


\section{CRITICALITY SAFETY EVALUATION REPORT FOR THE MULTI-CANISTER OVERPACK}

October 1999

Prepared for the U.S. Department of Energy

Office of Environmental Restoration and Waste Management

DE\&S Hanford, Incorporated

Fluor Daniel Northwest

Richland, Washington 99352 
HNF-SD-SNF-CSER-005 REV 5

This page intentionally left blank. 


\section{CONTENTS}

1.0 INTRODUCTION AND SUMMARY OF LIMIT AND CONTROLS $\ldots \ldots \ldots \ldots \ldots$ 1-1

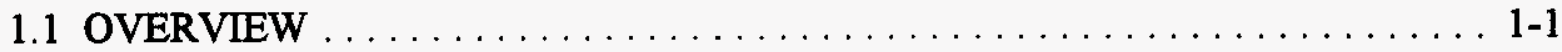

1.2 LIMITS, CONTROLS, AND ENGINEERED FEATURES $\ldots \ldots \ldots \ldots \ldots \ldots 1-2$

1.3 DIMENSIONS REQUIRING QUALITY CONTROL VERIFICATION . . . . . . 1-3

2.0 DESCRIPTION OF FACILITY AND OPERATIONS $\ldots \ldots \ldots \ldots \ldots \ldots \ldots \ldots .2-1$

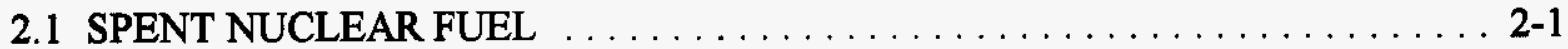

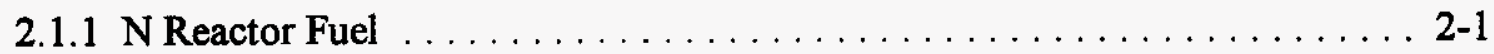

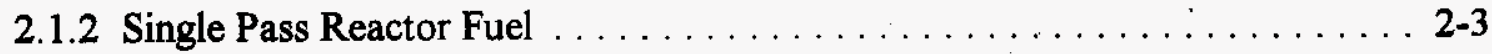

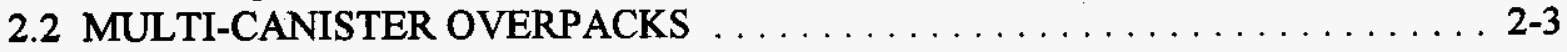

3.0 REQUIREMENTS AND EXEMPTIONS $\ldots \ldots \ldots \ldots \ldots \ldots \ldots \ldots \ldots \ldots$ 3-1

3.1 CRITICALITY SAFETY CRITERION FOR CALCULATION OF

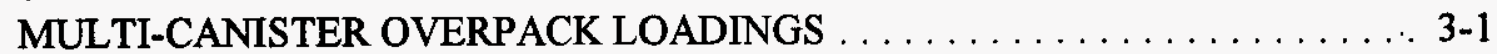

3.2 CRITERIA FOR ACCEPTABLE CRITICALITY DETERMINATIONS $\ldots \ldots \ldots$ 3-1

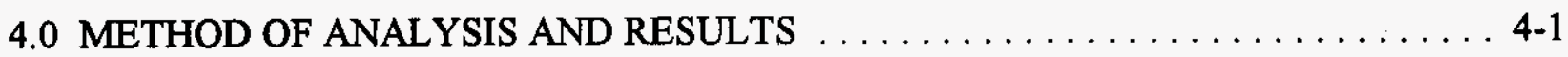

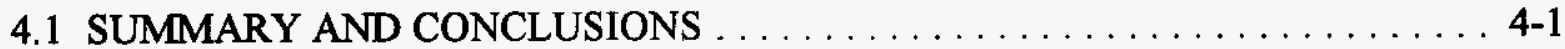

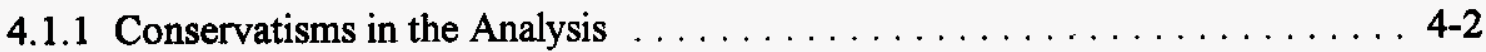

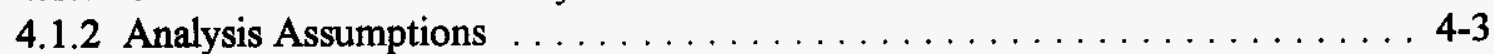

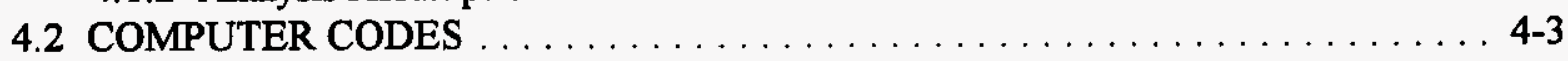

4.3 SPENT NUCLEAR FUEL FISSILE CHARACTERISTICS $\ldots \ldots \ldots \ldots \ldots$ 4-4

4.3.1 Spent Nuclear Fuel Description $\ldots \ldots \ldots \ldots \ldots \ldots \ldots \ldots \ldots \ldots \ldots .4 .4$

4.3.2 Spent Nuclear Fuel Reactivity Properties . . . . . . . . . . . . 4-4

4.4 MODELING OF THE MULTI-CANISTER OVERPACK,

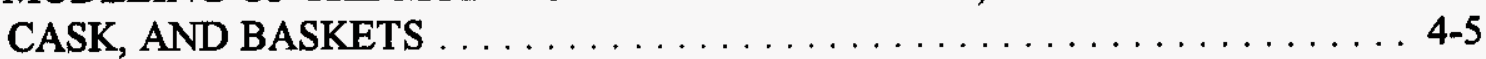

4.5 RESULTS OF CALCULATIONS FOR NORMAL CONDITIONS $\ldots \ldots \ldots \ldots$ 4-6

4.5.1 Determination of the Most Reactive Loading Configuration

for the Multi-Canister Overpacks $\ldots \ldots \ldots \ldots \ldots \ldots \ldots \ldots$ 4-6

4.5.2 Multi-Canister Overpacks Containing Single Pass Reactor Fuel . . . . . . . 4-8

4.5.3 Criticality Calculations for the Cold Vacuum Drying Facility . . . . . . . 4 4-17

4.5.4 Criticality Calculations for the Canister Storage Building ......... 4-18

4.5.5 Loading of the Long-Length Mark IA Assemblies in Mark IV

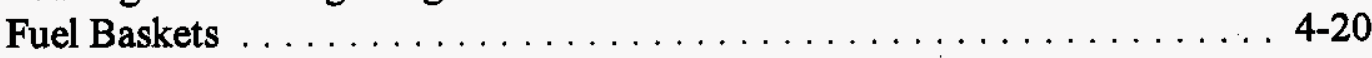

4.5.6 The Effects of Loading Mark IA Outer Elements in Mark IA Fuel

Baskets, With No Inner Elements $\ldots \ldots \ldots \ldots \ldots \ldots \ldots \ldots \ldots .4 .22$

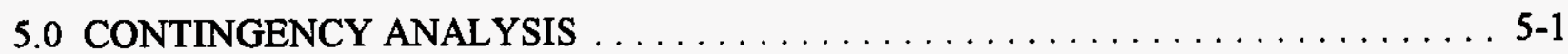

5.1 POTENTIAL ERROR AND FAILURE SITUATIONS $\ldots \ldots \ldots \ldots \ldots \ldots \ldots$ 5-1

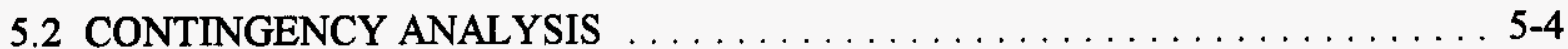

5.2.1 Receipt of a Multi-Canister Overpack in a Cask with a Drained Annulus . . . 5-4

5.2.2 Design Basis Drop Accidents . . . . . . . . . . . . . . . . . . . . 5-6 
5.2.3 Loading a Misloaded Basket $\ldots \ldots \ldots \ldots \ldots \ldots \ldots \ldots \ldots \ldots \ldots .8$

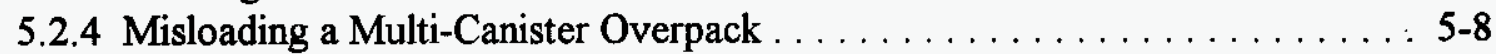

5.2.5 Flooding a Multi-Canister Overpack at the Canister Storage Building ... . 5-13

5.2.6 Flooding a Canister Storage Building Storage Tube ........... 5-15

5.2.7 Flooding at the Canister Storage Building Storage Array ........ 5-15

5.2.8 Handling a Flooded Multi-Canister Overpack with the Multi-Canister

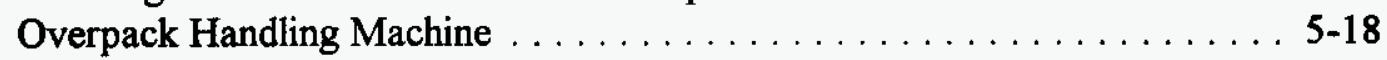

5.2.9 Loading a Multi-Canister Overpack in a Tube with no Intermediate

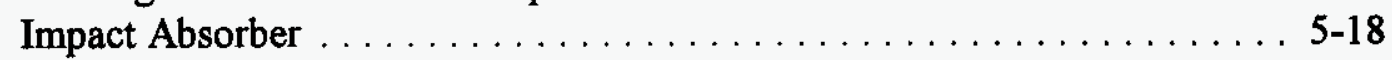

5.2.10 Flooding the Sampling/Weld Station with Glycol $\ldots \ldots \ldots \ldots \ldots \ldots$ 5-20

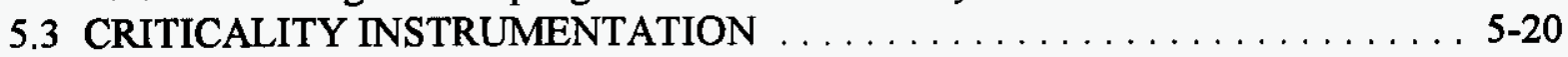

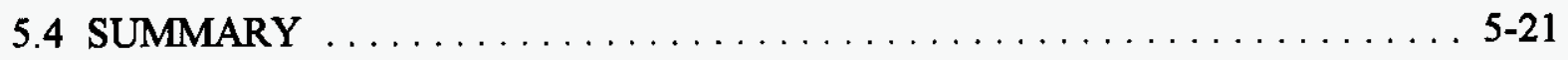

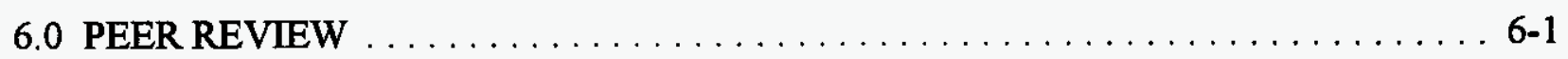

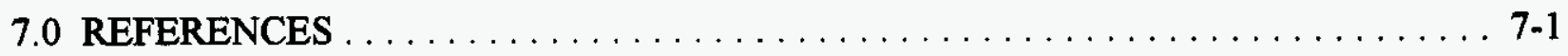

\section{APPENDIXES}

A VALIDATION OF CALCULATIONAL METHODS $\ldots \ldots \ldots \ldots \ldots \ldots \ldots$ A-1

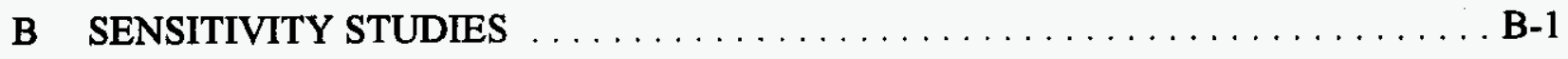

C ROD VERSUS SPHERICAL GEOMETRY FOR SCRAP OR RUBBLE MODEL . . . . C-1

D BURNUP EFFECTS ON N REACTOR MARK IV AND MARK IA FUEL . . . . . . D-1

E RADIAL ISOTOPIC PROFILE EVOLUTION DURING BURNUP $\ldots \ldots \ldots \ldots$ E-1

F REPRESENTATIVE MCNP INPUT FILES $\ldots \ldots \ldots \ldots \ldots \ldots \ldots \ldots \ldots \ldots \ldots$ F-1 


\section{LIST OF FIGURES}

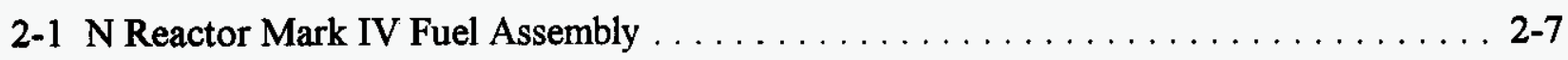

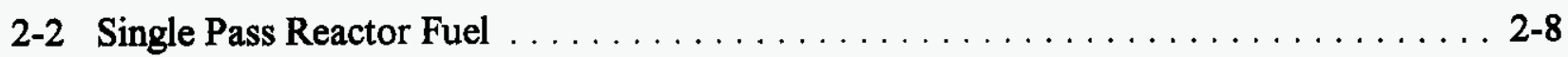

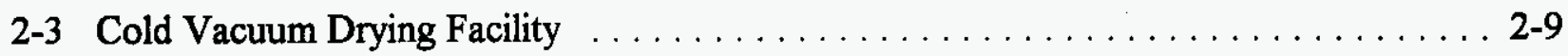

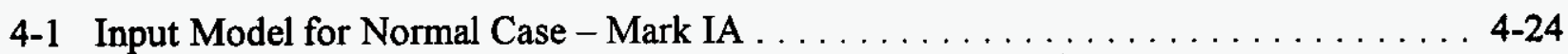

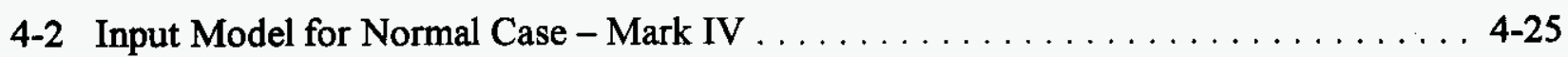

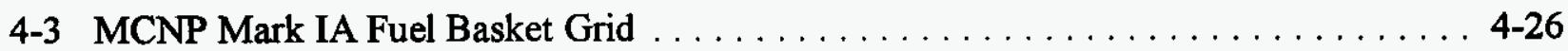

4-4 Maximum Reactivity Loading Arrangement for Mark IA Fuel in Multi-Canister

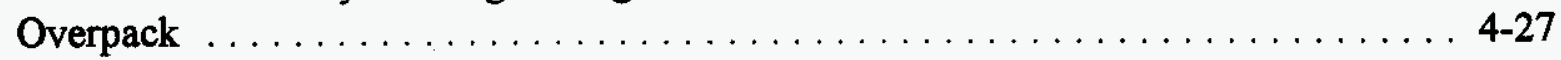

4-5 Maximum Reactivity Loading Arrangement for Mark IV Fuel in Multi-Canister

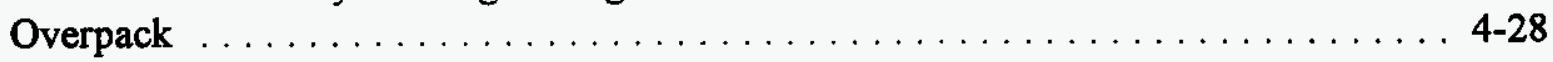

4-6 K-Effective During Draining of the Multi-Canister Overpack . . . . . . . . . . 4-29

4-7 Canister Storage Building Array and Storage Tube Layout $\ldots \ldots \ldots \ldots \ldots \ldots$ 4-30

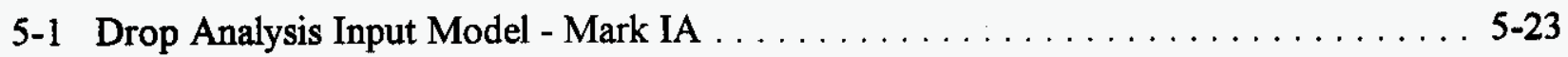

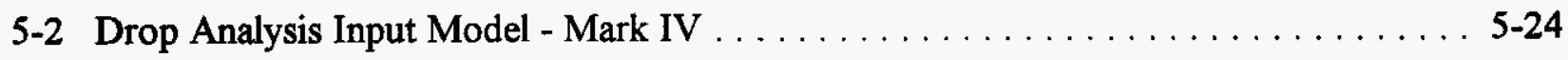

5-3 Interspersed Moderation for Flooded Mark IV Multi-Canister Overpacks in the

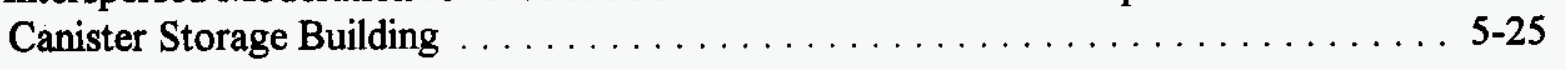

5-4 Interspersed Moderation for Dry Mark IV Multi-Canister Overpacks in the

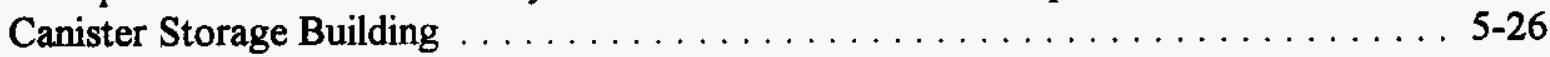

5-5 Water-Flooded Multi-Canister Overpack Loaded with Mark IV Fuel Being Lowered into a Canister Storage Building Storage Tube .............. 5-27 


\section{LIST OF TABLES}

2-1 Nominal Dimensions and Weights for N Reactor Fuel Assemblies

2-2 Maximum and Minimum Dimensions and Weights of Single Pass Reactor Fuel Assemblies in the K Basins . . . . . . . . . . . . . . . . . . . . .

4-1 Calculation Results for Normal Loading of Mark IA Multi-Canister Overpacks . . . . 4-7

4-2 Calculation Results for Normal Loading of Mark IV Multi-Canister Overpacks . . . . 4-7

4-3 Calculation Results for Partial Loadings of Empty Locations in the Mark IA Multi-Canister Overpack

4-4 Calculation Results for Partial Loadings of Locations Containing Single Outer Elements in a Mark IA Multi-Canister Overpack

4-5 Calculation Results for Partial Loadings of Locations Containing Single Inner Elements in a Mark IA Multi-Canister Overpack

4-6 Calculation Results for Partial Loadings of Empty Locations in a Mark IV Multi-Canister Overpack

4-7 Calculation Results for Partial Loadings of Locations Containing Single Outer Elements in a Mark IV Multi-Canister Overpack

4-8 Calculation Results for Partial Loadings of Locations Containing Single Inner Elements in a Mark IV Multi-Canister Overpack

4-9 Calculation Results for Partial Loadings of Locations Containing Combinations of Single Inner Elements, Single Outer Elements, and Empty Locations in a Mark IA Multi-Canister Overpack

4-10 Calculation Results for Partial Loadings of Locations Containing Combinations of Single Inner Elements, Single Outer Elements, and Empty Locations in a Mark IV Multi-Canister Overpack

4-11 Single Pass Reactor Fuel in Mark IA Scrap Baskets $\ldots \ldots \ldots \ldots \ldots \ldots \ldots$ 4-17

4-12 Mark IA Multi-Canister Overpack Reactivities During Draining . . . . . . . 4 4-17

4-13 Mark IV Multi-Canister Overpack Reactivities During Draining $\ldots \ldots \ldots \ldots \ldots$ 4-18

4-14 Multi-Canister Overpack Reactivities in the Canister Storage Building . . . . . . . 4-19 


\section{LIST OF TABLES (Continued)}

4-15 Calculation Results for Multi-Canister Overpacks Containing Long-Length Mark IA Fuel Assemblies in the Center of Mark IV Baskets

4-16 Calculation Results for Multi-Canister Overpacks Containing Long-Length Mark IA Fuel Assemblies in the Middle Row of Mark IV Baskets

4-17 Calculation Results for Multi-Canister Overpacks Containing Long-Length Mark IA Fuel Assemblies in the Outer Row of Mark IV Baskets

4-18 Calculation Results for Multi-Canister Overpacks Containing Mark IA

Fuel Baskets Loaded with only Mark IA Outer Elements

5-1 Calculation Results for Multi-Canister Overpacks Containing Long-Length Mark IA Fuel Assemblies in Mark IV Baskets with a Drained Annulus . . . . . . . . 5-5

5-2 Multi-Canister Overpack Drop Analysis for Fuel and Scrap Baskets $\ldots \ldots \ldots \ldots$ 5-7

5-3 Basket Misload Analysis for Mark IV Multi-Canister Overpacks $\ldots \ldots \ldots \ldots \ldots$ 5-9

5-4 Misload Analysis for Multi-Canister Overpacks $\ldots \ldots \ldots \ldots \ldots \ldots \ldots \ldots$ 5-10

5-5 Calculated Results for Misloaded Multi-Canister Overpack Stored in the Canister Storage Building.

5-6 Calculated Results for Multi-Canister Overpack Internal Flooding at Canister Storage Building $\ldots \ldots \ldots \ldots \ldots \ldots \ldots \ldots \ldots \ldots \ldots \ldots \ldots \ldots \ldots \ldots \ldots \ldots, 14$

5-7 Calculation Results for Canister Storage Building Storage Tube Flooding … . . 5-16

5-8 Calculation Results for Canister Storage Building Vault Flooding $\ldots \ldots \ldots \ldots \ldots$ 5-17

5-9 Flooded Multi-Canister Overpacks in the Multi-Canister Overpack Handling Machine and Lowered through the Canister Storage Building Floor ......... . 5-19

5-10 Canister Storage Building Array with Single Storage Tube Containing Two Multi-Canister Overpacks and No Intermediate Impact Absorber

5-11 Canister Storage Building Sampling/Weld Station Flooded with Propylene Glycol and Containing a Multi-Canister Overpack 


\section{ACRONYMS AND ABBREVIATIONS}

CSB Canister Storage Building

CSER criticality safety evaluation report

CVDF Cold Vacuum Drying Facility

MCNP Monte Carlo N-Particle Transport Code

MCO multi-canister overpack

MHM multi-canister overpack handling machine

SNF

spent nuclear fuel

SPR single pass reactor 


\section{CRITICALITY SAFETY EVALUATION REPORT FOR THE MULTI-CANISTER OVERPACK}

\subsection{INTRODUCTION AND SUMMARY OF LIMIT AND CONTROLS}

This criticality safety evaluation report (CSER) addresses the criticality analysis for spent nuclear fuel (SNF) inside a multi-canister overpack (MCO). The results reported in this revision of the CSER have been upgraded to incorporate the basket designs from HNF-S-0426, Performance Specification for Spent Nuclear Fuel Multi-Canister Overpack (Goldmann 1998).

\subsection{OVERVIEW}

SNF will be removed from existing canisters in both the $\mathrm{K}$ East and $\mathrm{K}$ West Basins, washed, sorted, loaded into baskets, and the baskets loaded into MCOs. Since the majority of the-SNF consists of spent N Reactor fuel, the basket designs are based on the Mark IV and Mark IA fuel assemblies.

A fraction of the fuel inventory is damaged or corroded and does not closely resemble fuel elements. This fissionable material is referred to as scrap. Scrap materials, and any additional scrap that may be generated during the fuel retrieval process, will be loaded into scrap baskets. Normally, Mark IV fuel scrap will be placed in Mark IV scrap baskets and Mark IA fuel scrap in Mark IA scrap baskets. Some single pass reactor (SPR) fuel also is stored in canisters in the K Basins. This fuel will be loaded into modified Mark IA baskets and loaded into an MCO that contains no other fuel type.

Baskets containing fuel or scrap are loaded into the MCO by the MCO loading system in the K Basins. An MCO can contain either six Mark IA baskets or five Mark IV baskets. Mark IA and Mark IV baskets are not mixed in the same MCO. Each MCO may be loaded with all fuel baskets, one scrap basket with the rest of the baskets being fuel baskets, or two scrap baskets with the rest being fuel baskets. By design, a Mark IA fuel basket may contain a maximum of 48 fuel assemblies, and a Mark IV basket may contain a maximum of 54 fuel assemblies.

Once the MCO has been loaded with baskets of fuel and scrap, it is sealed and the cask-MCO removed from the $\mathrm{K}$ Basin pool, the lid installed on the shipping cask, and the cask-MCO secured to a transporter. The cask-MCO is then taken to the Cold Vacuum Drying Facility (CVDF) where the water inside the MCO is removed. The dry cask-MCO is taken to the Canister Storage Building (CSB), and the MCO is removed from the cask. A cover cap is welded into place on top of the MCO, and the sealed MCO is then inserted into a tube in the CSB vault for interim storage. Some MCOs are monitored and will not have a welded cover cap installed until the monitoring campaign has been completed. 
The fissile materials in the $\mathrm{K}$ Basins that are to be put into the $\mathrm{MCO}$ baskets exist in different forms. These forms include whole fuel assemblies, parts of fuel assemblies (scrap), and oxides of corroded fuel. The terms used in this report to describe each modeling category are defined below.

- Fuel is any of the various forms of fuel located in the $\mathrm{K}$ Basins.

- Scrap is any fissile material and inseparable debris loaded into MCO scrap baskets. The enrichment of the scrap is defined as the maximum enrichment of any of the material contained in the scrap. This material is treated as optimally sized and spaced uranium rods.

- An assembly is $\mathrm{N}$ Reactor fuel consisting of both an inner and an outer element.

- Elements are individual inner or outer fuel elements.

- Rubble is compressed and fractured fuel assemblies that may result from an accident, such as a cask drop. Its enrichment is the average of the intact fuel that was rubblized.

- Unirradiated fuel is fuel with nominal ${ }^{235} \mathrm{U}$ enrichment.

Of the forms defined above, it should be noted that for equal volumes, the scrap is the most reactive form. Scrap models used in this report are optimally configured and therefore bound all forms of N Reactor and SPR uranium scrap.

\subsection{LIMITS, CONTROLS, AND ENGINEERED FEATURES}

This CSER shows that for all normal and accident conditions, the MCO loaded with fissile material will meet the acceptance criteria when the following limits and operational guidelines are met. Basket loading limits are specified in HNF-SD-SNF-CSER-010, Criticality Safety Evaluation Report for the K Basin Fuel Retrieval Subproject (Kessler and Peck 1999).

Limit 1 A maximum of two baskets of scrap, one in the top and one in the bottom, may be loaded into an MCO.

Basis: $\quad$ Scrap has been modeled as optimally sized rods at optimal water moderation. Placing scrap at both ends of the stack of baskets in the MCO limits the $k_{\text {eff }}$ to less than 0.95 for all credible accidents. The limit of two scrap baskets and their locations is based on heat removal from the MCO and is specified in HNF-SD-SNF-OCD-001, Spent Nuclear Fuel Project Product Specification (Pajunen 1998). 
The features of the MCO and Mark IA baskets engineered to be safety class as a geometry control to ensure safety (Goldmann 1998) include:

- The MCO shell

- The filter guard plate

- The shield plug

- The Mark IA fuel and scrap basket base plate

- The Mark IA fuel and scrap basket center post

- The Mark IA fuel and scrap basket outer trapezoidal bars.

In addition, the maximum allowable radial deflection of the center post during a design basis accident is 2 in. The maximum inner diameter of the MCO shell during a design basis accident is $23.25 \mathrm{in}$.

\subsection{DIMENSIONS REQUIRING QUALITY CONTROL VERIFICATION}

The following dimensions require quality control verification during fabrication:

- The inner diameter of the MCO can be $23.025 \pm 0.01$ in.

- The Mark IA base plate nominal thickness is 1.23 in. to 1.25 in. 


\section{HNF-SD-SNF-CSER-005 REV 5}

This page intentionally left blank. 


\subsection{DESCRIPTION OF FACILITY AND OPERATIONS}

SNF is to be removed from existing canisters in both the K East and $\mathrm{K}$ West Basins. The intact fuel assemblies, fuel pieces, or scrap will be loaded into fuel and scrap baskets, and the baskets loaded into MCOs. The loaded MCOs will be transported to the CVDF for draining and drying and then to the CSB for long-term interim storage. This chapter briefly describes the SNF, the MCOs into which it will be loaded, the CVDF, and the CSB.

\subsection{SPENT NUCLEAR FUEL}

WHC-SD-NR-CSER-009, Criticality Safety Evaluation K Basin Storage Rack Seismic Qualification (Wittekind 1993), and UNI-3894, Procedures, Methods and Models for Neutronic Analysis of N Reactor (Burnside et al. 1987), provide the essential specifications for the intact fuel assemblies to be loaded into the MCO. Unless otherwise stated, this CSER uses the longest fuel assembly length for the Mark IV fuel assemblies because they contain the most fissile material and tend to be the most reactive. The Mark IA intact fuel is modeled as 20.9 in. long, the most common length. Twelve Mark IA assemblies are 26.1 in. long and, because of their length, cannot be loaded into a Mark IA basket. They have been analyzed to allow them to be loaded into a Mark IV fuel basket. A small amount of Mark IA fuel is stored in the K East Basin. This material will be loaded in Mark IV baskets in accordance with the limits in HNF-SD-SNF-CSER-010 (Kessler and Peck 1999).

\subsubsection{N Reactor Fuel}

The vast majority of the 2,100 metric tons of irradiated fuel in the $\mathrm{K}$ Basins is from the $\mathrm{N}$ Reactor. There are two basic fuel assembly types, designated Mark IV and Mark IA. Figure 2-1 illustrates a typical Mark IV N Reactor fuel assembly (Mark IA assemblies are similar). The N Reactor fuel has a tube-within-a-tube design.

Mark IV fuel assemblies have a pre-irradiation enrichment of $0.95 \mathrm{wt} \%{ }^{235} \mathrm{U}$ in both elements and a maximum weight of $51.6 \mathrm{lb}$. They have an outside diameter of $2.42 \mathrm{in}$. and lengths of $17.4 \mathrm{in.}$ to $26.1 \mathrm{in.}$ Other types of N Reactor fuel stored at the K Basins are Mark IB, IC, IVB, and IVC. Mark IB and IVB have preirradiation enrichments of $0.71 \mathrm{wt} \%{ }^{235} \mathrm{U}$ and Mark IC has a preirradiation enrichment of $0.95 \mathrm{wt} \%{ }^{235} \mathrm{U}$. These fuel types are handled as Mark IV fuel. The Mark IVC fuel has a preirradiation enrichment of $1.15 \mathrm{wt} \%{ }^{235} \mathrm{U}$ in the outer element and $0.95 \mathrm{wt} \%{ }^{235} \mathrm{U}$ in the inner element. No Mark IVC fuel is currently stored in the K Basins.

Mark IA assemblies have a pre-irradiation enrichment of $1.25 \mathrm{wt} \%{ }^{235} \mathrm{U}$ in the outer element, 0.95 $\mathrm{wt} \%{ }^{235} \mathrm{U}$ in the inner element, and a maximum weight of $36.6 \mathrm{lb}$. They have an outside diameter of $2.40 \mathrm{in}$. and lengths of $14.9 \mathrm{in}$. to $26.1 \mathrm{in.}$ Only 12 Mark IA assemblies are $26.1 \mathrm{in.} \mathrm{long.}$ Table 2-1 provides a detailed listing of the $\mathrm{N}$ Reactor fuel dimensions and weights. The majority of the Mark IA material is stored in the $\mathrm{K}$ West Basin. Only a very small amount of Mark IA material is stored in the $\mathrm{K}$ East Basin. 
Table 2-1. Nominal Dimensions and Weights for N Reactor Fuel Assemblies.

\begin{tabular}{|c|c|c|c|c|}
\hline & \multicolumn{2}{|c|}{ Mark IV fuel assembly } & \multicolumn{2}{|c|}{ Mark IA fuel assembly } \\
\hline Outer tube diameters: & $(\mathrm{cm})$ & (in.) & (cm) & (in.) \\
\hline Zirconium cladding, outer diameter & 6.160 & 2.425 & 6.106 & 2.404 \\
\hline Uranium, outer diameter & 6.032 & 2.375 & 5.979 & 2.354 \\
\hline Uranium, inner diameter & 4.422 & 1.741 & 4.592 & 1.808 \\
\hline Zirconium cladding, inner diameter & 4.321 & 1.701 & 4.481 & 1.764 \\
\hline Outer tube enrichment: & \multicolumn{2}{|c|}{$(w t \%)$} & \multicolumn{2}{|c|}{$(w t \%)$} \\
\hline${ }^{235} \mathrm{U}$ & \multicolumn{2}{|c|}{$0.94700^{\mathrm{a}}$} & \multicolumn{2}{|c|}{1.2500} \\
\hline${ }^{236} \mathrm{U}$ & \multicolumn{2}{|c|}{0.03920} & \multicolumn{2}{|c|}{0.0392} \\
\hline${ }^{238} \mathrm{U}$ & \multicolumn{2}{|c|}{99.0138} & \multicolumn{2}{|c|}{98.7108} \\
\hline Inner tube diameters: & $(\mathrm{cm})$ & (in.) & (cm) & (in.) \\
\hline Zirconium cladding, outer diameter & 3.249 & 1.279 & 3.165 & 1.246 \\
\hline Uranium, outer diameter & 3.096 & 1.219 & 2.962 & 1.166 \\
\hline Uranium, inner diameter & 1.321 & 0.520 & 1.245 & 0.490 \\
\hline Zirconium cladding, inner diameter & 1.219 & 0.480 & 1.118 & 0.440 \\
\hline Inner tube enrichment: & \multicolumn{2}{|c|}{$(w t \%)$} & \multicolumn{2}{|c|}{$(w t \%)$} \\
\hline${ }^{235} \mathrm{U}$ & \multicolumn{2}{|c|}{$0.94700^{\mathrm{a}}$} & \multicolumn{2}{|c|}{0.94700} \\
\hline${ }^{236} \mathrm{U}$ & \multicolumn{2}{|c|}{0.03920} & \multicolumn{2}{|c|}{0.03920} \\
\hline${ }^{238} \mathrm{U}$ & \multicolumn{2}{|c|}{99.0138} & \multicolumn{2}{|c|}{99.0138} \\
\hline Fuel assembly dimensions: & $(\mathrm{cm})$ & (in.) & $(\mathrm{cm})$ & (in.) \\
\hline Maximum length & 66.294 & 26.10 & $53.035^{b}$ & $20.88^{b}$ \\
\hline End cap thickness & 0.483 & 0.19 & 0.483 & 0.19 \\
\hline Fuel assembly weight: & $(\mathrm{kg})$ & (lb) & $(\mathrm{kg})$ & (lb) \\
\hline Maximum weight & 23.4 & 51.6 & 16.6 & 36.6 \\
\hline
\end{tabular}

"Mark IVB fuel consists of natural uranium $\left(0.71 \mathrm{wt} \%{ }^{235} \mathrm{U}\right)$ in both the outer and inner tubes, which correspond to Mark IV tube diameters and assembly lengths of 19.9, 23.2, and $26.1 \mathrm{in.}$

'There are twelve Mark IA assemblies that are 26.1-in. long. 
A significant portion of the $\mathrm{N}$ Reactor fuel stored in the $\mathrm{K}$ East Basin has undergone corrosion as a result of cladding damage during fuel handling. The fuel in many cases has swollen from the uranium corrosion, causing further damage to the cladding, and leading to further corrosion. The fuel stored in the $\mathrm{K}$ West Basin was encapsulated in water-filled canisters with an added corrosion inhibitor. Analyses performed on samples of fuel from these canisters have shown that this fuel is significantly less corroded than the fuel in the K East Basin (Makenas 1998). For this CSER, the corrosion rates of the fuel in both basins were assumed to be the same. In addition, some of the $\mathrm{K}$ West Basin canisters show evidence of leakage.

\subsubsection{Single Pass Reactor Fuel}

The K Basins also contain an estimated 3.9 metric tons $(0.16 \%$ of the total inventory) of irradiated fuel from Hanford Site SPRs. The inventory lists $183 \mathrm{~kg}$ of $0.95 \mathrm{wt} \%{ }^{235} \mathrm{U}$ fuel and $98 \mathrm{~kg}$ of fuel of unknown enrichment. The rest of the SPR fuel is either natural or depleted uranium metal with a ${ }^{235} \mathrm{U}$ weight fraction of up to $0.72 \%$.

SPR fuel has a machined uranium core with aluminum alloy cladding. Initial enrichment levels for unirradiated SPR fuel range from $0.114 \mathrm{wt} \%$ to $2.1 \mathrm{wt} \%{ }^{235} \mathrm{U}$. While the enrichment of the unidentified fuel is not expected to exceed $1.25 \mathrm{wt} \%{ }^{235} \mathrm{U}$, the analyses for this CSER assumed it was $2.1 \mathrm{wt} \%{ }^{235} \mathrm{U}$ enriched. A sketch of typical SPR fuel elements appears in Figure 2-2. The SPR fuel diameter varies from 1.35 in. to 1.88 in., while fuel length varies from 5.55 in. to 8.98 in. Weight varies from $2.08 \mathrm{~kg}$ to $6.75 \mathrm{~kg}(4.58$ to $14.9 \mathrm{lb})$ per fuel element.

The majority of the SPR fuel was depleted to $0.06 \mathrm{wt} \%{ }^{235} \mathrm{U}$ with a high fraction of the plutonium in the fuel, $27 \mathrm{wt} \%$, being ${ }^{240} \mathrm{Pu}$. This highly depleted fuel has an individual assembly weight of $3.57 \mathrm{~kg}(7.87 \mathrm{lb})$, an outer diameter of $1.51 \mathrm{in}$., and a length of $8.65 \mathrm{in}$. Table 2-2 provides a detailed listing of the dimensions and weights of SPR fuel stored in the K Basins.

The majority of the SPR fuel is assumed to be in good condition with minimal cladding damage. However, some SPR fuel has been damaged by handling or by galvanic reactions between its cladding and incompatible metals.

\subsection{MULTI-CANISTER OVERPACKS}

The MCO is a single-use container that consists of a cylindrical shell, five to six baskets, a shield plug, and features necessary for maintaining the structural integrity of the MCO while providing criticality control and fuel drying capability. The safety basis of the MCO requires it to maintain the SNF in a critically safe configuration (Goldmann 1998). 
Table 2-2. Maximum and Minimum Dimensions and Weights of Single Pass Reactor Fuel Assemblies in the K Basins.

\begin{tabular}{|l|c|c|c|c|}
\hline & \multicolumn{2}{|c|}{ Maximum } & \multicolumn{2}{c|}{ Minimum } \\
\hline Diameters: & (cm) & (in.) & (cm) & (in.) \\
\hline Aluminum cladding, outer diameter & 5.04 & 1.98 & 3.67 & 1.44 \\
\hline Uranium, outer diameter & 4.78 & 1.88 & 3.44 & 1.35 \\
\hline Uranium, inner diameter & 1.38 & 0.543 & 1.08 & 0.424 \\
\hline Aluminum cladding, inner diameter & 1.10 & 0.433 & 0.787 & 0.310 \\
\hline Enrichments: & \multicolumn{2}{|c|}{$(\mathrm{wt} \%)$} & \multicolumn{2}{|c|}{$(\mathrm{wt} \%)$} \\
\hline${ }^{235} \mathrm{U}$ & \multicolumn{2}{|c|}{2.1} & \multicolumn{2}{c|}{0.114} \\
\hline Fuel assembly dimensions: & $(\mathrm{cm})$ & $(\mathrm{in})$. & $(\mathrm{cm})$ & (in.) \\
\hline Length & 22.8 & 8.98 & 14.1 & 5.55 \\
\hline End cap thickness & 0.635 & .250 & 0.635 & .250 \\
\hline Fuel assembly weight: & $(\mathrm{kg})$ & $(\mathrm{lb})$ & $(\mathrm{kg})$ & (lb) \\
\hline Uranium core & 6.75 & 14.9 & 2.08 & 4.58 \\
\hline
\end{tabular}

The MCO shell is a stainless steel cylindrical vessel that is closed with a stainless steel shield plug. The shell is fabricated from 24 -in. diameter, schedule $80 \mathrm{~S}$ pipe with a nominal wall thickness of $0.5 \mathrm{in}$.; it has an overall length of $166 \mathrm{in}$. with the cover cap installed. The maximum diameter of the MCO's internal cavity is 23.25 in. (Goldmann 1998), and it is approximately $145 \mathrm{in}$. long. The $\mathrm{MCO}$ has a bottom end plate that has a constant thickness of $2.0 \mathrm{in}$. except in the center region, where it is 1.13 in. thick. A stainless steel closure shield plug assembly is used to seal the MCO after loading. This assembly contains internal high-efficiency particulate air (HEPA) filters to prevent contamination of the process ports. Ports for MCO processing are provided in the top part of the shield plug assembly. The filter guard plate on the bottom of the assembly protects the HEPA filters. The vessel holds baskets, which contain fuel or scrap, and incidental equipment. Incidental equipment includes a support tube nesting feature on the filter guard plate and bottom plate, two process tubes connected to shield plug process ports, and sealing features.

All MCO baskets are stainless steel, annular, open-top containers with a maximum outer dimension of 22.6 in. Each fuel basket has six rods that support the fuel basket above. At the minimum, approximately 0.3 in. of clearance exists between the top of the fuel assemblies and the lower surface of the basket above. All baskets incorporate a center support tube for axial support during lifting. 
The fuel baskets are designed to support fuel assemblies vertically in individual sockets bored into the 2.5-in.-thick fuel rack that is installed above the basket baseplate. An outer skirt provides additional lateral support and confinement for smaller sections of fuel assemblies. Only those portions of a combined fuel assembly (i.e., an outer and an inner element) that will fit in the basket's fuel rack are loaded into a fuel basket. Solo outer or inner elements may be combined to make up a complete fuel assembly or placed in the basket as single elements. Those portions of the fuel assemblies that are greater than $0.25 \mathrm{in}$. in diameter but less than approximately 3 in. in length, or are too broken up to stand upright in the fuel basket, or will not fit in the fuel rack because of swelling caused by damage or corrosion also are placed in a scrap basket.

Each scrap basket has a fines compartment around the center pipe (center post for the Mark IA baskets) into which the smaller particles of scrap are placed. The size of the fines compartment is intentionally set to limit the amount of fine particles allowed within any one scrap basket. A fine particle is defined as any piece of fuel scrap larger than $0.25 \mathrm{in}$. in diameter but smaller than approximately $1 \mathrm{in}$. in diameter. Particles smaller than $0.25 \mathrm{in}$. in diameter are handled by the water treatment system installed in the $\mathrm{K}$ Basins.

Because of their higher initial enrichment, Mark IA fuel assemblies and scrap are normally segregated from Mark IV assemblies and scrap. The Mark IA fuel is limited to 48 fuel assemblies per basket. A 6.6-in.-outer-diameter center post with a 1.75-in-diameter bore is inserted in the center of both the fuel and scrap baskets to physically exclude fuel and scrap from the center region of the baskets. The insert is designed to allow less than a 2-in. offset from center in the MCO in the event of a worst-case drop accident (Goldmann 1998). Six Mark IA baskets will fit inside an $\mathrm{MCO}$.

Mark IV fuel assemblies have a lower initial enrichment than Mark IA fuel assemblies, allowing 54 Mark IV fuel assemblies to be loaded per fuel basket. Both the Mark IV fuel and scrap baskets contain a small center pipe to allow the insertion of the long process tube for draining but do not need a center post for criticality control. Because Mark IV fuel assemblies are longer than the Mark IA assemblies, five Mark IV baskets will fill an MCO.

The fuel is unloaded from the canisters and loaded into the baskets remotely underwater in the basin pools. The baskets are queued and then loaded into the $\mathrm{MCO}$, which is also underwater in the load-out pit. The analyses performed in this CSER allow the loading of a maximum of two scrap baskets in an MCO, one on the bottom and one on the top. Loading an MCO with a single scrap basket or only fuel baskets also is allowed.

The MCO is housed in a shipping cask and surrounded by an immersion pail that provides a clean water housing during loading. Once the MCO is loaded, the shield plug is installed, the cask and MCO are lifted out of the pool, and the shield plug is secured with the locking ring. The lid is placed on the cask, the cask-MCO is loaded on a transporter, and the unit is moved to the CVDF.

The CVDF has four processing bays that can each house a loaded transporter and a fifth spare bay that could be modified for use if required. A typical processing bay layout is shown in Figure 2-3. After the transporter has been placed in a bay, the cask lid is removed, a process 
hood installed, and process lines connected to the shield plug assembly. The water inside the MCO is pumped to a receiver tank in the process water conditioning system, and the interior of the $\mathrm{MCO}$ is dried. Temperatures inside the MCO are controlled by circulating water in the annulus between the MCO and the shipping cask. When the MCO has been determined to be sufficiently dry, the cask annulus water is drained and the MCO and cask are prepared for shipping to the CSB.

The CSB has three storage vaults. Vault 1, which will contain the MCOs, has 220 storage tubes arranged in a 10 by 22 array. The vaults are surrounded by vertical concrete walls that neutronically isolate the fissionable material in each vault from adjacent vaults. When the transporter arrives at the CSB, the MCO is removed from the shipping cask, placed in a storage tube, or sealed with a welded cover cap and then placed in a storage tube. Two MCOs are placed in each storage tube in a vertical column. Impact absorbers are placed at the bottom of each tube and between the MCOs to limit the impact forces on an MCO should the MCO drop into the storage tube. 
Figure 2-1. N Reactor Mark IV Fuel Assembly.

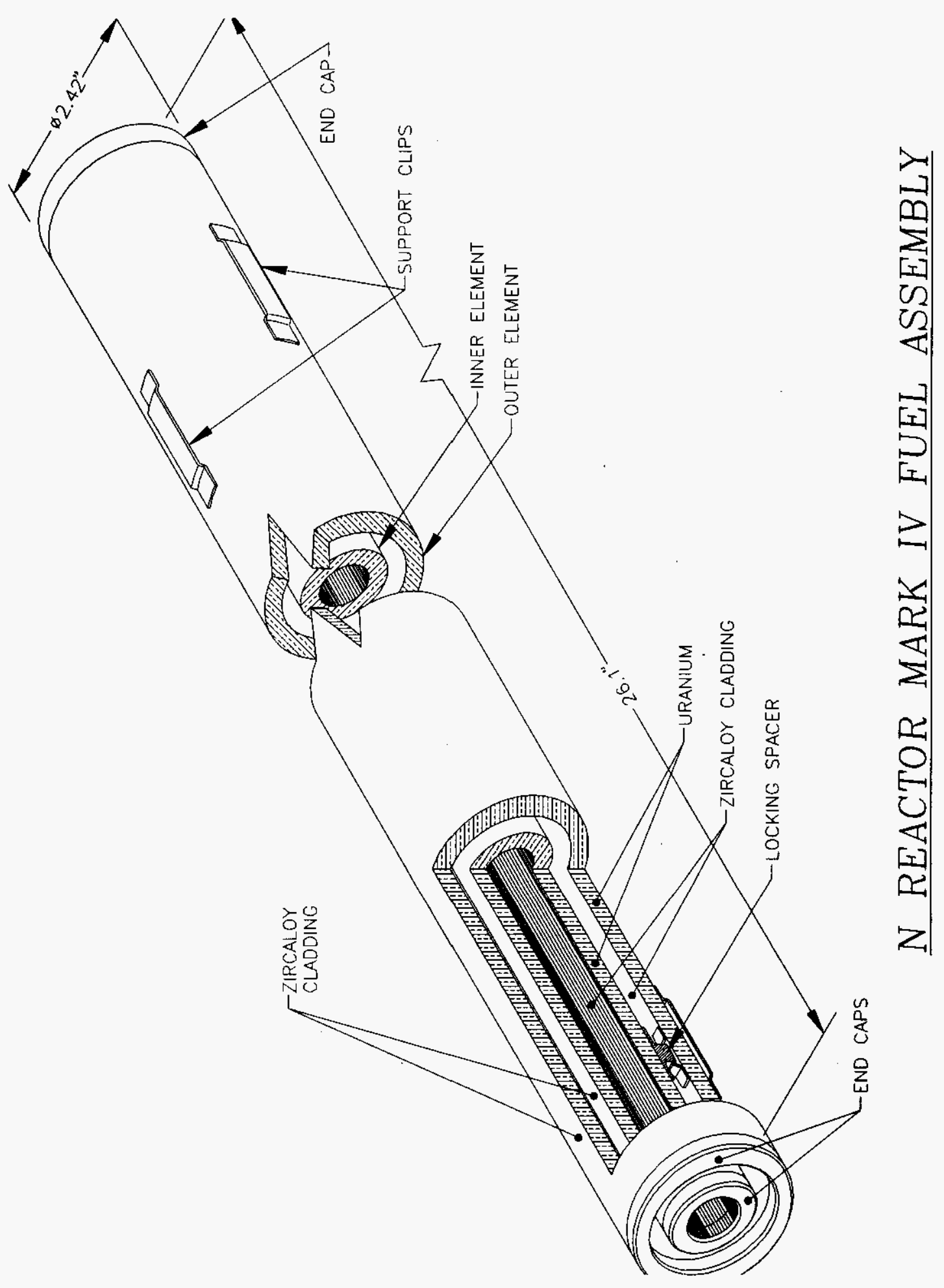




\section{HNF-SD-SNF-CSER-005 REV 5}

Figure 2-2. Single Pass Reactor Fuel.

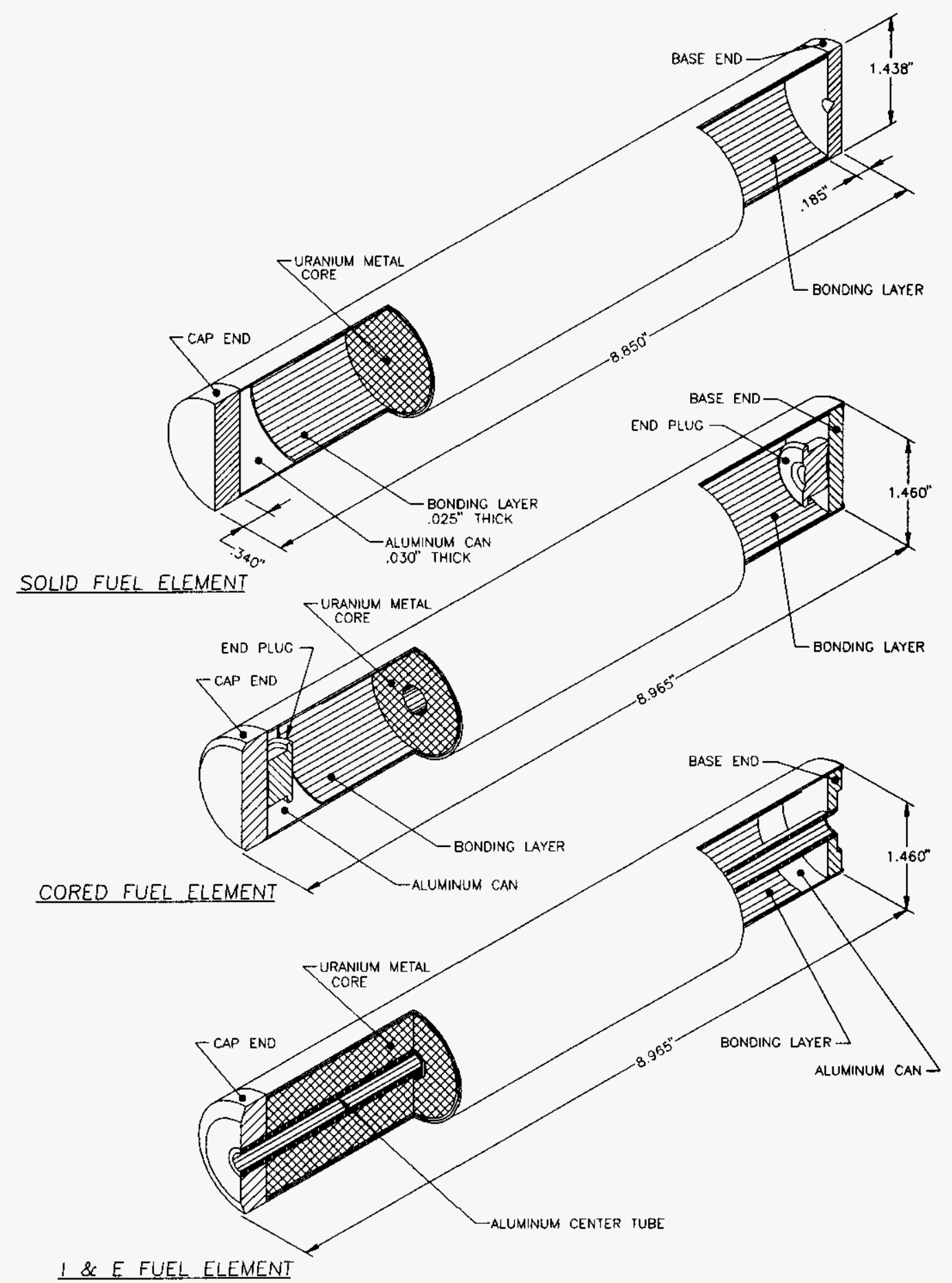


HNF-SD-SNF-CSER-005 REV 5

Figure 2-3. Cold Vacuum Drying Facility.

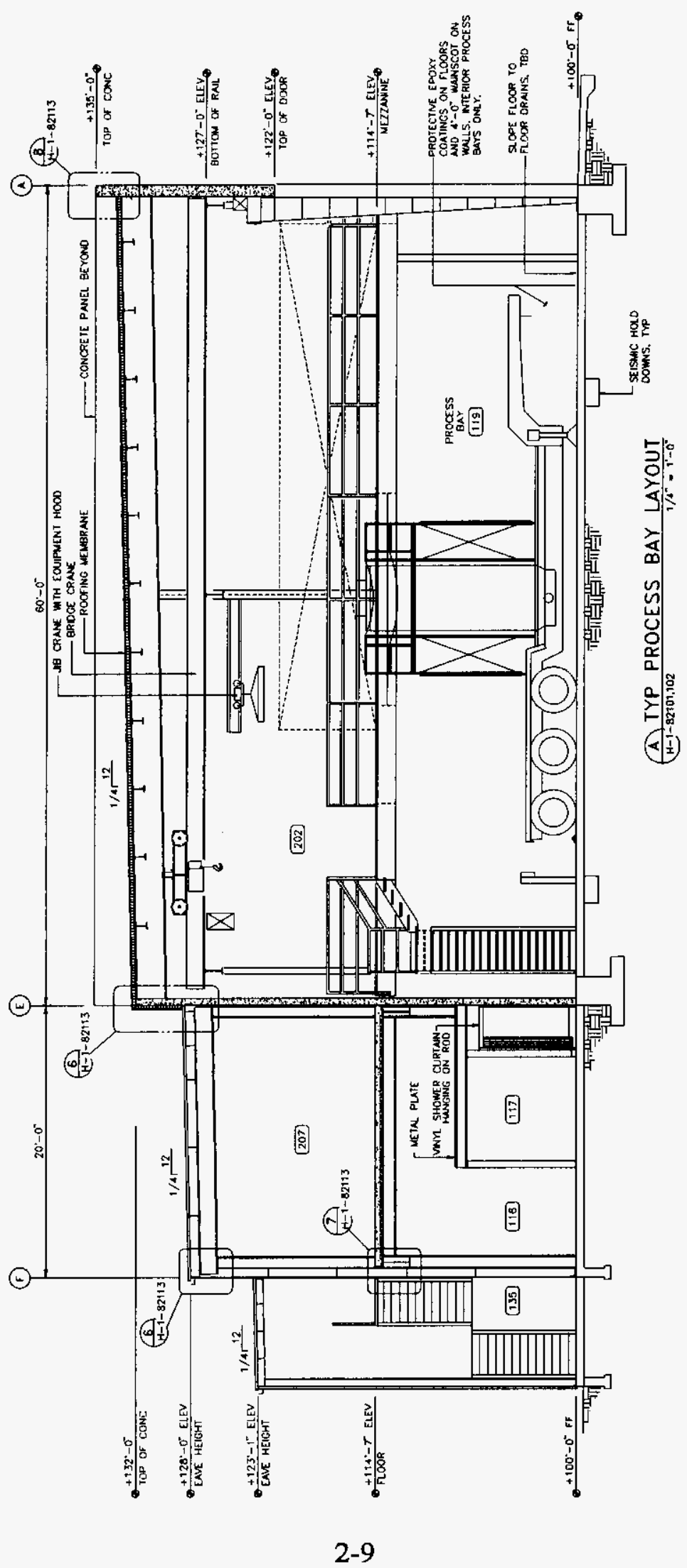


HNF-SD-SNF-CSER-005 REV 5

This page intentionally left blank. 


\subsection{REQUIREMENTS AND EXEMPTIONS}

This analysis must meet the requirements of HNF-PRO-539, Criticality Safety Evaluations. No exemptions from these requirements apply to this evaluation.

\subsection{CRITICALITY SAFETY CRITERION FOR CALCULATION OF MULTI-CANISTER OVERPACK LOADINGS}

The criticality safety criterion for MCO loading, transport from the K Basins to the CVDF, operations in the CVDF, transport from the CVDF to the CSB, and operations in the CSB requires that $\mathrm{k}_{\text {eff }}$ be less than 0.95 (Garvin 1997), which meets the requirements of HNF-PRO-537, Criticality Safety Control of Fissionable Material, including the double contingency principle. The double contingency principle requires that process designs incorporate sufficient factors of safety that at least two unlikely, independent, and concurrent changes in process conditions occur before a criticality accident is possible. The analysis in this CSER must demonstrate compliance with the double contingency principle by showing that allowed fuel and scrap configurations will not exceed a $\mathrm{k}_{\mathrm{eff}}$ of 0.95 for violation of any single contingency. Contingencies include MCO drops, misloadings, and flooding while in storage.

\subsection{CRITERIA FOR ACCEPTABLE CRITICALITY DETERMINATIONS}

The criticality safety criterion, used to judge the acceptability of a calculated neutron multiplication factor $\left(\mathrm{k}_{\mathrm{eff}}\right)$ for fissile configuration, must account for the bias inherent in the code and cross sections used, any uncertainties in the physical problem being analyzed, and the uncertainties in both the bias determination (the experimental basis) and the calculational methods. This may be stated as follows:

$$
\mathrm{k}_{\mathrm{eff}}=\mathrm{k}_{\mathrm{calc}}-\Delta \mathrm{k}_{\mathrm{biss}}+\left({\sigma_{\mathrm{b}}}^{2}+\sigma_{\mathrm{c}}{ }^{2}+\sigma_{\mathrm{d}}{ }^{2}+\sigma_{\mathrm{e}}{ }^{2}+\sigma_{\mathrm{T}}{ }^{2}\right)^{1 / 2}<\mathrm{k}_{\text {limit }}
$$

where

$$
\begin{aligned}
& \mathrm{k}_{\text {timit }}=\text { criticality prevention criterion }(0.95) \\
& \mathrm{k}_{\text {calc }}=\text { calculated result } \\
& \Delta \mathrm{k}_{\text {bias }}=\text { methods bias } \\
& \sigma_{\mathrm{b}}=\text { bias uncertainty } \\
& \sigma_{\mathrm{c}}=\text { calculational uncertainty } \\
& \sigma_{\mathrm{d}}=\text { uncertainty in dimensional tolerances } \\
& \sigma_{\mathrm{c}}=\text { uncertainty in enrichment tolerances } \\
& \sigma_{\mathrm{T}}=\text { uncertainty in temperature change. }
\end{aligned}
$$


The calculated $k_{\text {eff }}$ must be at the $95 \%$ confidence level. ' Thus, inserting the values into the formula and applying the one-tailed test to the standard deviation gives

$$
\mathrm{k}_{\mathrm{eff}}=\mathrm{k}_{\mathrm{calc}}-\Delta \mathrm{k}_{\mathrm{bias}}+\left[\left(2 \sigma_{\mathrm{b}}\right)^{2}+1.645^{2}\left({\sigma_{\mathrm{c}}}^{2}+{\sigma_{\mathrm{d}}}^{2}+\sigma_{\mathrm{e}}{ }^{2}+\sigma_{\mathrm{T}}{ }^{2}\right)\right]^{1 / 2}<0.95
$$

where

$\Delta \mathrm{k}_{\text {biat }}=-0.0004$ (Schmittroth 1996)

$\sigma_{b}=0.005$ (Schmittroth 1996)

$\sigma_{\mathrm{c}}=$ calculational standard deviation (varies with each calculation)

$\sigma_{\mathrm{d}}=0.000546$ (Appendix B)

$\sigma_{\mathrm{o}}=0.001840$ (Appendix B)

$\sigma_{\mathrm{T}}=0.000810$ (Appendix B).

The equation above then simplifies to

$$
\mathrm{k}_{\text {eff }}=\mathrm{k}_{\text {calc }}+0.0004+\left[0.01^{2}+1.645^{2}\left(\sigma_{\mathrm{c}}^{2}+0.002083^{2}\right)\right]^{1 / 2}<0.95 .
$$

No uncertainty is calculated for variations in the position of the scrap basket in the MCO. This is because the scrap basket is modeled such that the scrap is as close as possible to the bottom of the fuel basket, and the scrap basket sides are expanded as widely as possible to conserve mass. The dimensions used exceed the manufacturing tolerances for the basket. The effect on $\mathrm{k}_{\text {eff }}$ of the height of the scrap in the basket is shown by cases mk $4 \mathrm{r} .0$ and mk $4 \mathrm{r} 0.1$ in Table 4-2. In the case mk4r.0, the scrap is modeled up to the bottom of the fuel basket above it, while in case $\mathrm{mk} 4 \mathrm{r} 0.1$, the basket sides are removed, and the scrap is modeled to the inner side of the MCO with a small gap above the top of the scrap. The highest $k_{\text {eff }}$ is calculated for the first case and no specific uncertainty for the scrap basket is required. 


\subsection{METHOD OF ANALYSIS AND RESULTS}

\subsection{SUMMARY AND CONCLUSIONS}

This section of the analysis describes the normal conditions of the MCO in the K Basins, the CVDF, and the CSB. Analysis has shown that the $\mathrm{k}_{\mathrm{eff}}$ of the contents of the loaded shipping cask under normal conditions will be below 0.95 by a substantial degree. Loaded shipping casks containing MCOs flooded with water and loaded with intact $\mathrm{N}$ Reactor fuel assemblies will have values for $k_{\text {eff }}$ less than 0.93 . Loaded shipping casks containing dry MCOs loaded with intact $\mathrm{N}$ Reactor fuel assemblies will have values for $k_{\text {eff }}$ less than 0.33 . MCOs in arrays of 10 by 22 by 2 in the CSB tubes, when dry, have values for $k_{\text {eff }}$ of less than 0.36 for any density water between the tubes.

An MCO containing dry fuel or scrap material cannot be made critical under any conditions. Criticality is a concern in situations in which there is water moderation internal to the MCO. MCOs containing Mark IV or Mark IA fuel have values of $k_{\text {eff }}<0.85$ for flooded intact fuel loadings under normal conditions. Loading scrap into the top and bottom baskets with intact fuel in the other baskets results in a $k_{\text {eff }}$ less than 0.91 for a flooded Mark IA MCO and less than 0.93 for a flooded Mark IV MCO.

Placing Mark IV fuel assemblies, components, or scrap together in baskets designed for Mark IA fuel (which contain the center post for geometry control) is allowed because of the lower unit reactivity of Mark IV fuel. However, with the exceptions described in HNF-SD-SNF-CSER-010 (Kessler and Peck 1999), no assemblies, components, or scrap with uranium enrichment greater than $0.95 \mathrm{wt} \%{ }^{235} \mathrm{U}$ may be loaded into fuel baskets that do not contain the center post without additional analysis. Separate criticality analyses have been performed to allow the loading of the 12 long Mark IA assemblies from the $\mathrm{K}$ West Basin into a Mark IV basket containing Mark IV fuel. A small amount of Mark IA fuel and scrap also is stored in the K East Basin. The fuel assemblies are stored in single fuel element containers and the scrap is stored in remnant return canisters, which are limited to one per barrel of a canister. Each single fuel element container or remnant return canister may contain no more than $52.5 \mathrm{~kg}$ of material (Kessler and Peck 1999) for a total of $105 \mathrm{~kg}$ per canister. This fuel and scrap also may be loaded into a Mark IV basket in accordance with the limits in HNF-SD-SNF-CSER-010 (Kessler and Peck 1999) and into an MCO.

The inside diameter of the MCO limits the maximum diameter of the fuel to 23.25 in. None of the components of the Mark IV baskets are required to control the geometry of the Mark IV fuel for criticality safety. Both the base plate and center post of the Mark IA basket are required to maintain the favorable geometry of the Mark IA fuel by preventing fuel from accumulating in the center of the basket.

An MCO may be loaded in one of three ways: all fuel baskets, one scrap basket and the rest fuel baskets, or two scrap baskets and the rest fuel baskets. There are no minimum loading requirements for either the fuel or scrap baskets. Analysis has shown that the most reactive state 
for the Mark IA MCOs is with two scrap baskets and partially loaded fuel baskets containing 47 fuel assemblies with one empty location in a middle row location. The most reactive configuration for the Mark IV MCO is with two scrap baskets and fuel baskets that each contain 53 assemblies with one inner element only loaded in an outer row location. Section 4.5.1 describes this analysis in detail and these are the configurations designated as the base cases unless otherwise stated in the analysis.

The model for the MCO at the CVDF is flooded, loaded with partially loaded fuel baskets as described above, and two scrap baskets - one at the top and one at the bottom - and in a cask with a flooded annulus. Since the MCO is always in a cask at the CVDF and each cask is in a separate processing bay, each $\mathrm{MCO}$ is isolated neutronically from other MCOs and is analyzed alone.

The normal condition in the CSB is for the vault to have a 10 by 22 by 2 array of normally loaded MCOs containing less than $0.0051 \mathrm{~g} / \mathrm{cm}^{3}$ of water $(3 \mathrm{~kg})$. With a conservative water density between the tubes of $0.0012 \mathrm{~g} / \mathrm{cm}^{3}$, the upper limit of the neutron multiplication factor is approximately 0.36 , although with optimal interspersed water moderation between storage tubes, this value may increase to 0.42 , as shown in Chapter 5.0. This is less than half the allowable limit of 0.95 .

The effects of fuel length, cask-MCO gap, and the migration of uranium corrosion products from the upper fuel elements to the lower baskets have been addressed in a sensitivity analysis (see Appendix B). The results show only insignificant changes in reactivity.

\subsubsection{Conservatisms in the Analysis}

Many conservatisms have been built into this analysis.

- The safety limit is 0.95 . The margin of safety provided by using the 0.95 limit for the low-enriched uranium metal fuel in the K Basins is far greater than the margin of safety provided by using the same limit for the greater enrichment of commercial fuels on which the limit is based.

- It is assumed that the baskets completely fail in an accident.

- The reduction of reactivity resulting from fuel burnup, fission products in the spent fuel, and other nonfissionable material introduced as contaminants in the K Basin sludge and fuel debris, is not included in the analyses (although burnup effects are discussed in Appendix D).

- The scrap is completely optimized (i.e., optimum particle size and optimum water-tofuel ratio). 
- The fuel rubbilizes to optimized scrap in a drop accident.

- The most reactive loading configuration of the MCO fuel baskets is used.

\subsubsection{Analysis Assumptions}

The analyses performed to evaluate the acceptability of the normal and accident conditions for the MCO were based on the assumptions defined below.

Assumption 1 The MCO is either always in a cask, loaded into the MHM, in the CSB storage tubes, or in the CSB sampling/weld station when flooded with water. Note that flooded MCOs in the MHM, CSB storage tubes, or CSB sampling/weld station were analyzed as a contingency.

Assumption 2 Mark IA fuel or scrap is normally loaded into Mark IA fuel or scrap baskets, which have the center post that serves as a criticality feature to exclude fissile material from the center of the basket. The only exceptions to this are for the 26.1-in.-long Mark IA fuel assemblies and the Mark IA material stored in the K East Basin, which will be loaded into Mark IV baskets.

Assumption 3 The credible misloading scenario for Mark IA fuel being inadvertently loaded into a Mark IV basket is 14 Mark IA fuel assemblies. For scrap this is equivalent to $155 \mathrm{~kg}$, the mass of 14 Mark IA outer elements, with an enrichment of $1.25 \mathrm{wt} \%{ }^{235} \mathrm{U}$.

Assumption 4 Following the drop of a Mark IV MCO, the basket base plates remain intact. These plates are not safety class; however their mass is conserved in the models.

Assumption 5 The misload model for Mark IV scrap baskets includes the center pipe.

\subsection{COMPUTER CODES}

The analysis tools used in the preparation of this document are the WIMS- $E^{1}$ code (Gubbins et al. 1982) and the GOLF code (Schwinkendorf 1994), which have been used for parametric studies and the calculation of ideal geometry critical dimensions, and the MCNP code (Breismeister 1993, Carter 1996), which has been used for modeling of three-dimensional geometries in detail. The WIMS-E lattice transport code was used to generate infinite neutron

${ }^{1}$ WIMS is the trademark of Answers, the marketing organization of the United Kingdom Atomic Energy Authority, Winfrith, England. 
multiplication factors, $\mathrm{k}_{\infty}$, for lattices and two-group cross sections for use by GOLF, which was used to calculate finite radial dimensions for both cylinders and hemispheres. The MCNP code has been used for all criticality calculations to verify compliance with the 0.95 limit for $k_{\text {eff }}$. Appendix A presents the validation of the criticality computer codes used to demonstrate the acceptability of the MCO $\mathrm{k}_{\text {eff }}$. The most recent calculations for this CSER were performed using version $4 \mathrm{~B}$ to the MCNP code. This version has been verified and validated for use on all computing platforms on the Hanford Site (Hillesland and Schwinkendorf 1998, Schwinkendorf 1998, Erickson 1998).

\subsection{SPENT NUCLEAR FUEL FISSILE CHARACTERISTICS}

\subsubsection{Spent Nuclear Fuel Description}

For this CSER, the nominal baseline configuration for the MCO is five baskets of Mark IV fuel assemblies, 270 total assemblies, or six baskets of Mark IA fuel assemblies, 288 total assemblies. The fuel baskets are not required to be fully loaded, and the most reactive configurations are for partially loaded baskets, as described in Section 4.5.1. Two scrap baskets may be loaded into the $\mathrm{MCO}$, one at the top and one at the bottom, replacing baskets loaded with intact fuel.

Scrap baskets may be loaded with fuel scrap or segments of fuel assembly components, with or without cladding. Such scrap material comprises a small fraction of the material stored in the $\mathrm{K}$ Basins, and additional scrap may be generated as part of the fuel retrieval process. The weight limits for scrap in the baskets are $980 \mathrm{~kg}(2,156 \mathrm{lb})$ of Mark IV scrap and $575 \mathrm{~kg}(1,265 \mathrm{lb})$ of Mark IA scrap (Kessler and Peck 1999). These scrap limits are based on spills of the baskets in the $\mathrm{K}$ Basins where there is sludge containing fissile material on the floor. For Mark IV scrap at optimum spacing, a full basket would contain less than $980 \mathrm{~kg}$ because of the center pipe in the basket used to house the long axial process tube and the basket sides. A basket containing $575 \mathrm{~kg}$ of Mark IA scrap at optimum spacing will not be full.

SPR fuel elements will be loaded into modified Mark IA baskets and into MCOs containing no N Reactor fuel (Kessler and Peck 1999).

\subsubsection{Spent Nuclear Fuel Reactivity Properties}

The spent $\mathrm{N}$ Reactor fuel has a burnup range based on ${ }^{240} \mathrm{Pu}$ content - the higher the burnup, the higher the total plutonium content, the higher the percentage of ${ }^{240} \mathrm{Pu}$ in total plutonium, and the higher the fission product concentration. The presence of plutonium isotopes, specifically ${ }^{239} \mathrm{Pu}$ and ${ }^{241} \mathrm{Pu}$, in the spent fuel tends to compensate for the reactivity loss due to ${ }^{235} \mathrm{U}$ depletion but not enough to increase reactivity beyond that of unirradiated fuel. All values for $\mathrm{k}_{\text {eff }}$ are conservatively calculated using unirradiated fuel and scrap containing no fission products. 
The 8 in. of stainless steel in the cask surrounding the payload provides appreciable neutron reflection, which increases $\mathrm{k}_{\text {eff }}$ more than would a pure water reflector. When the contents are dry, there is no neutron moderation. Low-enriched uranium metal cannot be made critical without moderation; therefore, the fully loaded MCO cannot go critical when dry, no matter what reflector is present.

Intact Mark IV and Mark IA fuel assemblies do not provide optimal geometry for maximum reactivity in a water-moderated lattice (Schwinkendorf 1995). Scrap pieces of the assembly's component metal could be reconfigured into more reactive clusters, depending on the assumed piece size and average spacing (or packing fraction). The WIMS-E computer code (Gubbins et al. 1982) was used to evaluate $\mathrm{k}_{\infty}$ for various scrap fuel configurations representative of loading scrap in baskets in an MCO to determine the optimal configuration of scrap material - that which produces the highest reactivity per unit mass. These calculations have not been used to establish whether the MCO satisfies the $\mathrm{k}_{\text {eff }}<0.95$ criticality safety limit under either normal or accident conditions, but rather to determine the optimal scrap configuration and to guide the modeling of the MCNP calculations. The scrap was represented in the WIMS-E model as unirradiated uranium rods at various diameters and at various lattice pitches (for varying the water-to-fuel volume ratios). Optimization parameters for the scrap material were calculated in HNF-SD-SNF-CSER-010 (Kessler and Peck 1999). These parameters were used in the analysis for this document. The optimization parameters for scrap also were used to model the rubblized fuel.

\subsection{MODELING OF THE MULTI-CANISTER OVERPACK, CASK, AND BASKETS}

The Monte Carlo code MCNP (Breismeister 1993) was used to evaluate the three-dimensional criticality model of the shipping casks to verify that $k_{\text {eff }}$ was less than 0.95 . MCOs were modeled as 0.5 -in.-thick stainless steel cylinders with an internal diameter of 23.25 in. and a 2 -in.-thick base. The shield plug was modeled as a 9-in.-thick plate approximately 10 in. above the top basket. Approximately 1.5 in. above the top basket is a 1.5 -in.-thick plate used to protect the internal filters that are contained in the shield plug assembly. The filters were modeled as water for this analysis. Surrounding the MCO is the shipping cask. Figure 4-1 illustrates the loading arrangement for Mark IV baskets in the MCO. The Mark IV fuel assemblies were produced in different lengths, the longest being $26.1 \mathrm{in}$. For the calculational model, the length of the fuel assemblies was $26.1 \mathrm{in}$. Whole assemblies were modeled with the inner and outer metal annuli intact and with all the zirconium cladding in place.

Mark IA fuel assemblies were also produced in different lengths, the longest being 26.1 in. Only 12 of the $26.1 \mathrm{in}$.-long assemblies are stored in the K Basins, so the length of the majority of the assemblies, 20.9 in., was used for the calculational model. Because of their shorter length, MCOs holding Mark IA fuel are loaded with six baskets. These baskets are fitted with a center post to prevent loading more than 48 fuel assemblies per basket. 
Both Mark IA and Mark IV scrap were modeled as optimally moderated and sized rods with cladding. Appendix $\mathrm{C}$ justifies the used of rods of scrap instead of spheres.

For baskets loaded with Mark IA material, the center post excludes material from the central region during normal and other credible abnormal conditions. Figure 4-2 shows the arrangement for loading Mark IA baskets. Because of their higher enrichment, Mark IA assemblies are not normally loaded into Mark IV baskets. However, loading Mark IV assemblies that are short enough to fit into Mark IA baskets would be acceptable because they would decrease $\mathrm{k}_{\text {eff }}$. The 26.1-in.-long Mark IA assemblies in the K West Basin and the Mark IA material stored in the K East Basin may be loaded into Mark IV baskets according to the limits specified in HNF-SD-SNF-CSER-010 (Kessler and Peck 1999).

To improve the heat removal capabilities of the scrap baskets, the sides are made from copper, not stainless steel, and copper plates have been added to the interior of the basket. These plates section the basket into a small region ( $10 \%$ of the basket volume) around the center post and six large sections. No copper was used in the scrap basket models used in the analysis. Adding copper plates to the basket interior both breaks up the optimal geometry of the scrap model and replaces water with copper, which has a higher absorption cross section ( 3.8 barns versus 0.7 barns [Lamarsh 1992]). Both of these effects will lower the $k_{\text {eff }}$. For conservatism, the original scrap basket model with stainless steel sides and no divider plates was retained.

\subsection{RESULTS OF CALCULATIONS FOR NORMAL CONDITIONS}

\subsubsection{Determination of the Most Reactive Loading Configuration for the Multi-Canister Overpacks}

An MCO may be loaded in several different configurations. The maximum loading of the fuel baskets is fixed by design and the loading of the scrap baskets is limited by HNF-SD-SNF-CSER-010 (Kessler and Peck 1999). There are no minimum loading requirements for any baskets. If scrap baskets are to be loaded into an $\mathrm{MCO}$, they are limited to the top and bottom tiers (Pajunen 1998). Thus, an MCO may contain all fuel baskets, one scrap basket in either the top or bottom tier with the fuel baskets in the remaining tiers, or two scrap baskets, one in the top and one in the bottom, and fuel baskets in the remaining tiers. For the Mark IV scrap baskets, two configurations were analyzed: one with no basket sides, which leaves no gap between the scrap and the inside diameter of the $\mathrm{MCO}$ and a small gap between the top of the scrap and the bottom of the fuel basket above it; and one with the diameter of the basket adjusted to leave no water gap between the top of the scrap and the bottom of the basket above. The analysis demonstrated that no uncertainty based on basket diameter is required. Tables 4-1 and 4-2 show the results for these loadings for Mark IA MCOs and Mark IV MCOs. 
Table 4-1. Calculation Results for Normal Loading of Mark IA Multi-Canister Overpacks.

\begin{tabular}{|c|c|c|c|c|}
\hline Case & MCO configuration & $\mathrm{k}_{\text {calc }}$ & $\sigma_{\mathrm{c}}$ & $\mathrm{k}_{\text {eff }}{ }^{*}$ \\
\hline $\mathrm{mk} 1 \mathrm{r} .0$ & $\begin{array}{c}\text { Two scrap baskets and four fuel } \\
\text { baskets }\end{array}$ & 0.88648 & 0.00096 & 0.89757 \\
\hline $\mathrm{mk1 \textrm {rf } . 0}$ & Six fuel baskets & 0.82607 & 0.00105 & 0.83718 \\
\hline $\mathrm{mk} 1 \mathrm{rf} .1$ & $\begin{array}{c}\text { Five fuel baskets and a scrap basket in } \\
\text { the top tier }\end{array}$ & 0.88558 & 0.00094 & 0.89666 \\
\hline $\mathrm{mk} 1 \mathrm{rf} .2$ & $\begin{array}{c}\text { Five fuel baskets and a scrap basket in } \\
\text { the bottom tier }\end{array}$ & 0.88488 & 0.00108 & 0.89600 \\
\hline
\end{tabular}
less than 0.95 .

${ }^{*} \mathrm{k}_{\mathrm{dff}}=\mathrm{k}_{\mathrm{calc}}+0.0004+\left((0.01)^{2}+(1.645)^{2}\left(\sigma_{\mathrm{c}}^{2}+0.002083^{2}\right)\right)^{1 / 2}$ as defined in Section 3.2. This value should be $\mathrm{MCO}=$ multi-canister overpack

Table 4-2. Calculation Results for Normal Loading of Mark IV Multi-Canister Overpacks.

\begin{tabular}{|c|c|c|c|c|}
\hline Case & MCO configuration & $\mathrm{k}_{\text {calc }}$ & $\sigma_{\mathrm{c}}$ & $\mathrm{k}_{\text {eff }}{ }^{*}$ \\
\hline $\mathrm{mk} 4 \mathrm{r} .0$ & $\begin{array}{c}\text { Two scrap baskets and three fuel } \\
\text { baskets }\end{array}$ & 0.91303 & 0.00071 & 0.92407 \\
\hline $\mathrm{mk} 4 \mathrm{rf} .0$ & Five fuel baskets & 0.83681 & 0.00087 & 0.84788 \\
\hline $\mathrm{mk} 4 \mathrm{rf} .1$ & $\begin{array}{c}\text { Four fuel baskets and a scrap basket in } \\
\text { the top tier }\end{array}$ & 0.91146 & 0.00087 & 0.92253 \\
\hline $\mathrm{mk} 4 \mathrm{rf} .2$ & $\begin{array}{c}\text { Four fuel baskets and a scrap basket in } \\
\text { the bottom tier }\end{array}$ & 0.91163 & 0.00092 & 0.92271 \\
\hline $\mathrm{mk} 4 \mathrm{r} 0.1$ & No basket sides for the scrap baskets & 0.88926 & 0.00073 & 0.90030 \\
\hline
\end{tabular}
less than 0.95 .

${ }^{*} \mathrm{k}_{\text {off }}=\mathrm{k}_{\mathrm{celo}}+0.0004+\left((0.01)^{2}+(1.645)^{2}\left(\sigma_{\mathrm{c}}{ }^{2}+0.002083^{2}\right)\right)^{1 / 2}$ as defined in Section 3.2. This value should be $\mathrm{MCO}=$ multi-canister overpack 
These results show that an MCO containing two scrap baskets with the fuel baskets has the highest $\mathrm{k}_{\text {eff }}$. Therefore, the base loading used to determine the most reactive possible loading for an MCO will include two scrap baskets, and the fuel baskets will be modeled as being partially loaded.

Figure 4-3 shows the MCNP grid used to model the Mark IA fuel baskets in the MCO. This grid is used to determine the location of vacancies and single elements using the row and column numbers. The numbers in the grid represent the fuel assemblies and the water in the basket. Figure 4-3 may also be used for Mark IV fuel baskets by replacing six of the inner water locations with fuel assemblies leaving only the center location as water. To determine the most reactive configuration for the $\mathrm{MCO}$, a single assembly location in each fuel basket was left empty or loaded with either an inner or outer element. After the most reactive configuration for each variation was determined, multiple vacancies, single elements, and mixed vacancies combined with single element cases were analyzed to determine their effect on reactivity. Tables 4-3 through 4-10 show these results.

The results in Tables 4-3 through 4-10 show that the most reactive loading for a Mark IA MCO contains two scrap baskets with four partially loaded fuel baskets, each containing 47 fuel assemblies. Each fuel basket has an empty location in the middle row (location 4,5 in Figure 4-3). Similarly, the most reactive loading for a Mark IV MCO contains two scrap baskets with three partially loaded fuel baskets, each containing 53 fuel assemblies and a single inner fuel element in location 3,6 . These loadings were used for all calculations in this document unless noted otherwise. Figures 4-4 and 4-5 show views of the most reactive fuel baskets.

\subsubsection{Multi-Canister Overpacks Containing Single Pass Reactor Fuel}

SPR fuel will be loaded into scrap baskets and into an MCO that is dedicated solely to SPR fuel. Because SPR fuel is stored in both basins, more than one MCO may be used. The geometry of the SPR fuel was modeled as aluminum-clad uranium cylinders based on representative fuel dimensions at optimum spacing and moderation. The depleted and $0.95 \mathrm{wt} \%{ }^{235} \mathrm{U}$ enriched fuels were represented by $0.95 \mathrm{wt} \%{ }^{235} \mathrm{U}$ enriched uranium. The 47 unidentified fuel elements are not expected to exceed an enrichment of $1.25 \mathrm{wt} \%{ }^{235} \mathrm{U}$. However, these fuel elements were modeled with uranium corresponding to $2.1 \mathrm{wt} \%{ }^{235} \mathrm{U}$, the highest enrichment used for special SPR fuel irradiations, for all criticality calculations. The mass of the unidentified fuel was modeled as a cylinder in the center of the tier 4 basket, the MCO loading that corresponds to the region of highest neutron importance.

The $k_{\text {eff }}$ for spr. 1 , shown in Table 4-11, is less than 0.85 . Comparison of the $k_{\text {eff }}$ with that of the most reactive Mark IA MCO loading illustrates that the Mark IA MCO is more limiting than the SPR MCO. Hence, the SPR MCO is bounded by the analyses of the Mark IA MCO. 
Table 4-3. Calculation Results for Partial Loadings of Empty Locations in the Mark IA Multi-Canister Overpack.

\begin{tabular}{|c|c|c|c|c|}
\hline Case & Empty locations & $k_{\text {calc }}$ & $\sigma_{\mathrm{c}}$ & $\mathrm{k}_{\text {eff }}{ }^{*}$ \\
\hline $\mathrm{mk1r.0}$ & None & 0.88648 & 0.00096 & 0.89757 \\
\hline $\mathrm{mk1r.1}$ & Row 5, column 5 & 0.88483 & 0.00096 & 0.89592 \\
\hline $\mathrm{mk} 1 \mathrm{r} .2$ & Row 4, column 5 & 0.89017 & 0.00096 & 0.90126 \\
\hline $\mathrm{mk} 1 \mathrm{r} .3$ & Row 3, column 5 & 0.88464 & 0.00098 & 0.89573 \\
\hline $\mathrm{mk1r.4}$ & Row 3, column 6 & 0.88851 & 0.00099 & 0.89961 \\
\hline $\mathrm{mk1r.5}$ & Row 4, column 6 & 0.88768 & 0.00111 & 0.89881 \\
\hline $\mathrm{mk1r.6}$ & Row 4, column 4 & 0.88643 & 0.00102 & 0.89753 \\
\hline $\mathrm{mk} 1 \mathrm{r} .10$ & Row 4, column 5; row 5, column 9; & 0.88808 & 0.00102 & 0.89918 \\
\hline $\mathrm{mk} 1 \mathrm{r} .11$ & Row 7, column 3 column 5; row 7, column 3 & 0.88635 & 0.00098 & 0.89744 \\
\hline $\mathrm{mk} 1 \mathrm{r} .12$ & Row 4, column 5; row 5, column 9 & 0.88557 & 0.00099 & 0.89667 \\
\hline $\mathrm{mk} 1 \mathrm{r} .13$ & $\begin{array}{c}\text { Row 4, column 5; row 5, column 9; } \\
\text { row 7, column 3; row 8, column 7 }\end{array}$ & 0.88690 & 0.00102 & 0.89800 \\
\hline
\end{tabular}
less than 0.95 .

$* k_{\text {off }}=k_{\text {calc }}+0.0004+\left((0.01)^{2}+(1.645)^{2}\left(\sigma_{c}^{2}+0.002083^{2}\right)\right)^{3 / 2}$ as defined in Section 3.2. This value should be MCNP calculation grid: $\mathrm{mklr}$

\begin{tabular}{|c|c|c|c|c|c|c|c|c|c|c|c|}
\hline & 1 & 2 & 3 & 4 & 5 & 6 & 7 & 8 & 9 & 10 & 11 \\
\hline 1 & & & & 8 & & ?a. & & & & & \\
\hline 2 & & & & 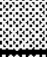 & V. & ব) & & & & & \\
\hline 3 & & & & . & 3 & 4 & & & & & \\
\hline 4 & & & & 6 & $\begin{array}{c}2,10,11, \\
12,13\end{array}$ & 5 & & & & & \\
\hline 5 & & & & & 1 & & & & $\begin{array}{c}10,12, \\
13\end{array}$ & & \\
\hline 6 & & & & & & sis & & & & & \\
\hline 7 & & & $\begin{array}{c}10,11, \\
13\end{array}$ & & & ; & & & & & \\
\hline 8 & & & & & & & 13 & & & & \\
\hline 9 & & & & & & & & & & & \\
\hline 10 & & & & & & & & & & & \\
\hline 11 & & & ; & & & & & & & & \\
\hline
\end{tabular}

Shaded cells represent water in the basket (universe 2 in the MCNP code), and the unshaded cells represent fuel assemblies (universe 3 in the MCNP code). 
Table 4-4. Calculation Results for Partial Loadings of Locations Containing Single Outer Elements in a Mark IA Multi-Canister Overpack.

\begin{tabular}{|c|c|c|c|c|}
\hline Case & $\begin{array}{c}\text { Locations containing single } \\
\text { outer elements }\end{array}$ & $\mathrm{k}_{\text {calc }}$ & $\sigma_{\mathrm{c}}$ & $\mathrm{k}_{\text {eff }}$ \\
\hline mk1r.0 & None & 0.88648 & 0.00096 & 0.89757 \\
\hline mk1ro.1 & Row 5, column 5 & 0.88618 & 0.00104 & 0.89729 \\
\hline mk1ro.2 & Row 4, column 5 & 0.88717 & 0.00103 & 0.89828 \\
\hline mk1ro.3 & Row 3, column 5 & 0.88805 & 0.00109 & 0.89917 \\
\hline mk1ro.4 & Row 3, column 6 & 0.88443 & 0.00148 & 0.89568 \\
\hline mk1ro.5 & Row 4, column 6 & 0.88786 & 0.00098 & 0.89895 \\
\hline mk1ro.6 & Row 4, column 4 & 0.88666 & 0.00106 & 0.89777 \\
\hline mk1ro.10 & Row 3, column 5; row 5, column 3; & 0.88564 & 0.00099 & 0.89674 \\
& row 9, column 7 & & \\
\hline mk1ro.11 & Row 3, column 5; row 9, column 7 & 0.88802 & 0.00096 & 0.89911 \\
\hline mk1ro.12 & Row 3, column 5; row 5, column 3 & 0.88552 & 0.00106 & 0.89663 \\
\hline
\end{tabular}

${ }^{*} \mathrm{k}_{\text {off }}=\mathrm{k}_{\text {calc }}+0.0004+\left((0.01)^{2}+(1.645)^{2}\left(\sigma_{0}{ }^{2}+0.002083^{2}\right)\right)^{3 / 2}$ as defined in Section 3.2. This value should be less than 0.95 .

MCNP calculation grid: mk1ro

\begin{tabular}{|c|c|c|c|c|c|c|c|c|c|c|c|}
\hline & 1 & 2 & 3 & 4 & 5 & 6 & 7 & 8 & 9 & 10 & 11 \\
\hline 1 & & & & & & & & & & & \\
\hline 2 & & & & & & & & & & & \\
\hline 3 & & & & & $\begin{array}{l}3,10 \\
11,12\end{array}$ & 4 & & & & & \\
\hline 4 & & & & 6 & 2 & $\overline{5}$ & & & & & \\
\hline 5 & & & 10,12 & & 1 & & & & & & \\
\hline 6 & & & & & & & & & & & \\
\hline 7 & & & & & & & & & & & \\
\hline 8 & & & & & & & & & & & \\
\hline 9 & 8 & & & & & & 10,11 & & & & \\
\hline 10 & & & & & & & & & & & \\
\hline 11 & & & & & & & & & & & \\
\hline
\end{tabular}

Shaded cells represent water in the basket (universe 2 in the MCNP code), and the unshaded cells represent fuel assemblies (universe 3 in the MCNP code). 
Table 4-5. Calculation Results for Partial Loadings of Locations Containing Single Inner Elements in a Mark IA Multi-Canister Overpack.

\begin{tabular}{|c|c|c|c|c|}
\hline Case & $\begin{array}{c}\text { Locations containing single } \\
\text { inner elements }\end{array}$ & $\mathrm{k}_{\text {calc }}$ & $\sigma_{\mathrm{c}}$ & $\mathrm{k}_{\text {eff }}$ \\
\hline mk1r.0 & None & 0.88648 & 0.00096 & 0.89757 \\
\hline mk1ri.1 & Row 5, column 5 & 0.88598 & 0.00100 & 0.89708 \\
\hline mk1ri.2 & Row 4, column 5 & 0.88538 & 0.00109 & 0.89650 \\
\hline mk1ri.3 & Row 3, column 5 & 0.88821 & 0.00095 & 0.89930 \\
\hline mk1ri.4 & Row 3, column 6 & 0.88815 & 0.00104 & 0.89926 \\
\hline mk1ri.5 & Row 4, column 6 & 0.88618 & 0.00092 & 0.89726 \\
\hline mk1ri.6 & Row 4, column 4 & 0.88707 & 0.00093 & 0.89815 \\
\hline mk1ri.10 & Row 3, column 6; row 6, column 3; & 0.88547 & 0.00106 & 0.89658 \\
\hline mk1ri.11 & Row 3, column 6; row 9, column 6 & 0.88793 & 0.00107 & 0.89905 \\
\hline mk1ri.12 & Row 3, column 6; row 6, column 3 & 0.88605 & 0.00106 & 0.89716 \\
\hline
\end{tabular}

${ }^{*} \mathrm{k}_{\text {off }}=\mathrm{k}_{\text {calc }}+0.0004+\left((0.01)^{2}+(1.645)^{2}\left(\sigma_{c}^{2}+0.002083^{2}\right)\right)^{1 / 2}$ as defined in Section 3.2. This value should be less than 0.95 .

\begin{tabular}{|c|c|c|c|c|c|c|c|c|c|c|c|}
\hline \multicolumn{12}{|c|}{ MCNP calculation grid: mklri } \\
\hline & 1 & 2 & 3 & 4 & 5 & 6 & 7 & 8 & 9 & 10 & 11 \\
\hline 1 & & & & & & & & : & & & \\
\hline 2 & & & & & & & & & & & \\
\hline 3 & & & & & 3 & $\begin{array}{l}4,10 \\
11,12\end{array}$ & & & & & \\
\hline 4 & & & 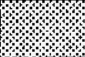 & 6 & 2 & 5 & & & & & \\
\hline 5 & & & & & 1 & & & & & & \\
\hline 6 & & : & 10,12 & & & & & & & & \\
\hline 7 & & & & & & & & & & & \\
\hline 8 & & & & & & & & & & & \\
\hline 9 & & & & & & 10,11 & & & & & \\
\hline 10 & & 8 & & & & & & & & & \\
\hline 11 & & & & & & & & & & & \\
\hline
\end{tabular}

Shaded cells represent water in the basket (universe 2 in the MCNP code), and the unshaded cells represent fuel assemblies (universe 3 in the MCNP code). 


\section{HNF-SD-SNF-CSER-005 REV 5}

Table 4-6. Calculation Results for Partial Loadings of Empty Locations in a Mark IV Multi-Canister Overpack.

\begin{tabular}{|c|c|c|c|c|}
\hline Case & Empty locations & $\mathrm{k}_{\text {calc }}$ & $\sigma_{c}$ & $\mathbf{k}_{\text {eff }}^{*}$ \\
\hline $\mathrm{mk} 4 \mathrm{r} .0$ & None & 0.91303 & 0.00071 & 0.92407 \\
\hline mk4r. 1 & Row 5 , column 5 & 0.91323 & 0.00094 & 0.92431 \\
\hline $\mathrm{mk} 4 \mathrm{r} .2$ & Row 4 , column 5 & 0.91270 & 0.00094 & 0.92378 \\
\hline $\mathrm{mk} 4 \mathrm{r} .3$ & Row 3 , column 5 & 0.91438 & 0.00094 & 0.92546 \\
\hline $\mathrm{mk} 4 \mathrm{r} .4$ & Row 3, column 6 & 0.91102 & 0.00090 & 0.92209 \\
\hline mk4r.5 & Row 4 , column 6 & 0.91182 & 0.00090 & 0.92289 \\
\hline $\mathrm{mk} 4 \mathrm{r} .6$ & Row 4 , column 4 & 0.91376 & 0.00098 & 0.92485 \\
\hline $\mathrm{mk} 4 \mathrm{r} .7$ & Row 5 , column 6 & 0.91061 & 0.00098 & 0.92170 \\
\hline $\mathrm{mk} 4 \mathrm{r} .8$ & Row 3 , column 5 ; row 5 , column 3 & 0.91254 & 0.00088 & 0.92361 \\
\hline $\mathrm{mk} 4 \mathrm{r} .9$ & Row 3 , column 5 ; row 9 , column 7 & 0.91461 & 0.00088 & 0.92568 \\
\hline $\mathrm{mk} 4 \mathrm{r} .10$ & $\begin{array}{l}\text { Row } 3 \text {, column } 5 \text {; row } 5 \text {, column } 3 \text {; } \\
\text { row } 9 \text {, column } 7\end{array}$ & 0.91408 & 0.00085 & 0.92514 \\
\hline mk4r.11 & $\begin{array}{l}\text { Row } 3 \text {, column } 5 \text {; row } 5 \text {, column } 3 \text {; } \\
\text { row } \text {, column } 9 \text {, row } 9 \text {, column } 7\end{array}$ & 0.91377 & 0.00085 & 0.92483 \\
\hline
\end{tabular}

${ }^{*} \mathrm{k}_{\text {eff }}=\mathrm{k}_{\text {ealc }}+0.0004+\left((0.01)^{2}+(1.645)^{2}\left(\mathrm{o}_{\mathrm{c}}{ }^{2}+0.002083^{2}\right)\right)^{1 / 1}$ as defined in Section 3.2. This value should be less than 0.95 .

MCNP calculation grid: $\mathrm{mk} 4 \mathrm{r}$

\begin{tabular}{|c|c|c|c|c|c|c|c|c|c|c|c|}
\hline & 1 & 2 & 3 & 4 & 5 & 6 & 7 & 8 & 9 & 10 & 11 \\
\hline 1 & & & & & & & & & & & \\
\hline 2 & & & & & & & & & & & \\
\hline 3 & & & & & $\begin{array}{l}3,8,9 \\
10,11\end{array}$ & 4 & & & & & \\
\hline 4 & & & & 6 & 2 & 5 & & & & & \\
\hline 5 & & & $\begin{array}{c}8,10 \\
11\end{array}$ & & 1 & 7 & & & & & \\
\hline 6 & & & & & & ? & & & & & \\
\hline 7 & & & & & & & & & 11 & & \\
\hline 8 & & & & & & & & & & & \\
\hline 9 & & & & & & & $\begin{array}{c}9,10 \\
11\end{array}$ & & & & \\
\hline 10 & & : & & & & প & & & 核 & & \\
\hline 11 & & & & & & & & & ( & & \\
\hline
\end{tabular}

Shaded cells represent water in the basket (universe 2 in the MCNP code), and the unshaded cells represent fuel assemblies (universe 3 in the MCNP code). 
Table 4-7. Calculation Results for Partial Loadings of Locations Containing Single Outer Elements in a Mark IV Multi-Canister Overpack.

\begin{tabular}{|c|c|c|c|c|}
\hline Case & Empty locations & $\mathbf{k}_{\text {calc }}$ & $\sigma_{c}$ & $\mathbf{k}_{\text {eff }}$ \\
\hline mk4r.0 & None & 0.91303 & 0.00071 & 0.92407 \\
\hline mk4ro.1 & Row 5, column 5 & 0.91234 & 0.00098 & 0.92343 \\
\hline mk4ro.2 & Row 4, column 5 & 0.91444 & 0.00089 & 0.92551 \\
\hline mk4ro.3 & Row 3, column 5 & 0.91359 & 0.00092 & 0.92467 \\
\hline mk4ro.4 & Row 3, column 6 & 0.91335 & 0.00091 & 0.92443 \\
\hline mk4ro.5 & Row 4, column 6 & 0.91133 & 0.00087 & 0.92240 \\
\hline mk4ro.6 & Row 4, column 4 & 0.91289 & 0.00097 & 0.92398 \\
\hline mk4ro.7 & Row 5, column 6 & 0.91226 & 0.00089 & 0.92333 \\
\hline mk4ro.10 & Row 4, column 5; row 5, column 9; & 0.91403 & 0.00085 & 0.92509 \\
& row 7, column 3 & & & \\
\hline mk4ro.11 & Row 4, column 5; row 7, column 3 & 0.91382 & 0.00087 & 0.92489 \\
\hline mk4ro.12 & Row 4, column 5; row 5, column 9 & 0.91162 & 0.00076 & 0.92266 \\
\hline mk4ro.13 & Row 4, column 5; row 5, column 9; & 0.91249 & 0.00080 & 0.92354 \\
& row 7, column 3; row 8, column 7 & & & \\
\hline
\end{tabular}

${ }^{*} \mathrm{k}_{\text {off }}=\mathrm{k}_{\text {calc }}+0.0004+\left((0.01)^{2}+(1.645)^{2}\left(\sigma_{\mathrm{o}}{ }^{2}+0.002083^{2}\right)\right)^{1 / 2}$ as defined in Section 3.2. This value should be less than 0.95 .

\begin{tabular}{|c|c|c|c|c|c|c|c|c|c|c|c|}
\hline \multicolumn{12}{|c|}{ MCNP calculation grid: mk4ro } \\
\hline & 1 & 2 & 3 & 4 & 5 & 6 & 7 & 8 & 9 & 10 & 11 \\
\hline 1 & & & & & צ. & & & ;: & & & . \\
\hline 2 & & & & & & . & & & & & צx. \\
\hline 3 & & & & & 3 & 4 & & & & & \\
\hline 4 & & & & 6 & $\begin{array}{c}2,10 \\
11,12 \\
13\end{array}$ & 5 & & & & & \\
\hline 5 & & & & & 1 & 7 & & & $\begin{array}{c}10,12 \\
13\end{array}$ & & \\
\hline 6 & & & & & & & & & & & \\
\hline 7 & & & $\begin{array}{c}10,11, \\
13\end{array}$ & & & & & & & & \\
\hline 8 & & & & & & & 13 & & & ; & 存: \\
\hline 9 & & & & & & & & & & & \\
\hline 10 & & & & & & & & & & & \\
\hline 11 & & & & & & & & & & & \\
\hline
\end{tabular}

Shaded cells represent water in the basket (universe 2 in the MCNP code), and the unshaded cells represent fuel assemblies (universe 3 in the MCNP code). 
Table 4-8. Calculation Results for Partial Loadings of Locations Containing Single Inner Elements in a Mark IV Multi-Canister Overpack.

\begin{tabular}{|c|c|c|c|c|}
\hline Case & Empty locations & $\mathrm{k}_{\text {calc }}$ & $\sigma_{\mathrm{c}}$ & $\mathrm{k}_{\text {eff }}{ }^{*}$ \\
\hline mk4r.0 & None & 0.91303 & 0.00071 & 0.92407 \\
\hline mk4ri.1 & Row 5, column 5 & 0.91100 & 0.00086 & 0.92207 \\
\hline mk4ri.2 & Row 4, column 5 & 0.91409 & 0.00082 & 0.92515 \\
\hline mk4ri.3 & Row 3, column 5 & 0.91244 & 0.00089 & 0.92351 \\
\hline mk4ri.4 & Row 3, column 6 & 0.91540 & 0.00084 & 0.92646 \\
\hline mk4ri.5 & Row 4, column 6 & 0.91312 & 0.00090 & 0.92419 \\
\hline mk4ri.6 & Row 4, column 4 & 0.91332 & 0.00086 & 0.92439 \\
\hline mk4ri.7 & Row 5, column 6 & 0.91184 & 0.00090 & 0.92291 \\
\hline mk4ri.10 & Row 3, column 6; row 6, column 3; & 0.91333 & 0.00086 & 0.92440 \\
\hline mk4ri.11 & Row 9, column 6 3, column 6; row 9, column 6 & 0.91421 & 0.00090 & 0.92528 \\
\hline mk4ri.12 & Row 3, column 6; row 6, column 3 & 0.91243 & 0.00081 & 0.92348 \\
\hline
\end{tabular}
less than 0.95 .

${ }^{*} \mathrm{k}_{\mathrm{eff}}=\mathrm{k}_{\mathrm{calc}}+0.0004+\left((0.01)^{2}+(1.645)^{2}\left(\sigma_{c}^{2}+0.002083^{2}\right)\right)^{1 / 2}$ as defined in Section 3.2. This value should be MCNP calculation grid: $\mathrm{mk} 4 \mathrm{ri}$

\begin{tabular}{|l|l|l|l|l|l|l|l|l|l|l|l|}
\hline & 1 & 2 & 3 & 4 & 5 & 6 & 7 & 8 & 9 & 10 & 11 \\
\hline 1 & & & & \\
\hline 2 & & & &
\end{tabular}

Shaded cells represent water in the basket (universe 2 in the MCNP code), and the unshaded cells represent fuel assemblies (universe 3 in the MCNP code). 
Table 4-9. Calculation Results for Partial Loadings of Locations Containing Combinations of Single Inner Elements, Single Outer Elements, and Empty Locations in a Mark IA Multi-Canister Overpack.

\begin{tabular}{|c|c|c|c|c|}
\hline Case & Configuration analyzed & $\overline{\mathrm{k}_{\text {calc }}}$ & $\sigma_{\mathrm{c}}$ & $k_{\text {eff }}^{*}$ \\
\hline mk1r.0 & None & 0.88648 & 0.00096 & 0.89757 \\
\hline mklrm. 1 & $\begin{array}{l}\text { Row } 3 \text {, column } 5 \text { inner element; } \\
\text { row } 4 \text {, column } 5 \text { empty }\end{array}$ & 0.88725 & 0.00097 & 0.89834 \\
\hline $\mathrm{mk} 1 \mathrm{rm} .2$ & $\begin{array}{l}\text { Row } 3 \text {, column } 5 \text { inner element; } \\
\text { row } 7 \text {, column } 8 \text { empty }\end{array}$ & 0.88502 & 0.00097 & 0.89611 \\
\hline $\mathrm{mk} 1 \mathrm{rm} .3$ & $\begin{array}{l}\text { Row } 3 \text {, column } 5 \text { outer element; } \\
\text { row } 4 \text {, column } 5 \text { empty }\end{array}$ & 0.88723 & 0.00095 & 0.89832 \\
\hline mk1rm.4 & $\begin{array}{l}\text { Row } 3 \text {, column } 5 \text { outer element; } \\
\text { row } 7 \text {, column } 8 \text { empty }\end{array}$ & 0.88592 & 0.00084 & 0.89698 \\
\hline $\mathrm{mk} 1 \mathrm{rm} .5$ & $\begin{array}{l}\text { Row } 3 \text {, column } 5 \text { outer element; } \\
\text { row } 7 \text {, column } 8 \text { empty; } \\
\text { row } 10, \text { column } 3 \text { inner element }\end{array}$ & 0.88598 & 0.00096 & 0.89707 \\
\hline
\end{tabular}

${ }^{*} \mathrm{k}_{\mathrm{off}}=\mathrm{k}_{\mathrm{calo}}+0.0004+\left((0.01)^{2}+(1.645)^{2}\left(\sigma_{\mathrm{c}}{ }^{2}+0.002083^{2}\right)\right)^{1 / 2}$ as defined in Section 3.2 . This value should be less than 0.95 .

MCNP calculation grid: $\mathrm{mklm}$

\begin{tabular}{|c|c|c|c|c|c|c|c|c|c|c|c|}
\hline & 1 & 2 & 3 & 4 & 5 & 6 & 7 & 8 & 9 & 10 & 11 \\
\hline 1 & & & & & & & & & & & \\
\hline 2 & & & & & & & & & & & \\
\hline 3 & & & & & $\begin{array}{c}1,2,3 \\
4,5\end{array}$ & & & & & & \\
\hline 4 & & & & & 1,3 & & & & & & \\
\hline 5 & & & & & & & & & & & \\
\hline 6 & & & & & & & & & & & \\
\hline 7 & & & & & & & & $2,4,5$ & & & \\
\hline 8 & & & & & & & & & & & \\
\hline 9 & & & & & & & & & & & \\
\hline 10 & & & 5 & & & & & & & & \\
\hline 11 & & & & & & & & & & & \\
\hline
\end{tabular}

Shaded cells represent water in the basket (universe 2 in the MCNP code), and the unshaded cells represent fuel assemblies (universe 3 in the MCNP code). 


\section{HNF-SD-SNF-CSER-005 REV 5}

Table 4-10. Calculation Results for Partial Loadings of Locations Containing Combinations of Single Inner Elements, Single Outer Elements, and Empty Locations in a Mark IV Multi-Canister Overpack.

\begin{tabular}{|c|c|c|c|c|}
\hline Case & Configuration analyzed & $\mathrm{k}_{\text {calc }}$ & $\sigma_{\mathrm{c}}$ & $\mathrm{k}_{\text {eff }}{ }^{*}$ \\
\hline $\mathrm{mk} 4 \mathrm{r} .0$ & None & 0.91303 & 0.00071 & 0.92407 \\
\hline $\mathrm{mk} 4 \mathrm{rm} .1$ & $\begin{array}{c}\text { Row 4, column 5 outer element; } \\
\text { row 3, column 5 empty }\end{array}$ & 0.91286 & 0.00089 & 0.92393 \\
\hline $\mathrm{mk} 4 \mathrm{rm} .2$ & $\begin{array}{c}\text { Row 4, column 5 outer element; } \\
\text { row 9, column 7 empty }\end{array}$ & 0.91120 & 0.00091 & 0.92228 \\
\hline $\mathrm{mk4rm} .3$ & $\begin{array}{c}\text { Row 3, column 6 inner element; } \\
\text { row 3, column 5 empty }\end{array}$ & 0.91414 & 0.00096 & 0.92523 \\
\hline $\mathrm{mk4rm} .4$ & $\begin{array}{c}\text { Row 3, column 6 inner element; } \\
\text { row 9, column 7 empty }\end{array}$ & 0.91196 & 0.00089 & 0.92303 \\
\hline $\mathrm{mk} 4 \mathrm{rm} .5$ & $\begin{array}{c}\text { Row 4, column 5 outer element; } \\
\text { row 9, column 7 empty; } \\
\text { row 3, column 6 inner element }\end{array}$ & 0.91255 & 0.00098 & 0.92364 \\
\hline $\begin{array}{c}\text { Row 4, column 5 outer element; } \\
\text { row 9, column 7 empty; } \\
\text { row 9, column 3 inner element }\end{array}$ & 0.91364 & 0.00095 & 0.92473 \\
\hline mk4rm.7 & $\begin{array}{c}\text { Row 9, column 7 outer element; and } \\
\text { row 6 column 9 outer element; } \\
\text { row 3, column 5 empty; } \\
\text { row 9, column 3 inner element }\end{array}$ & 0.91325 & 0.00095 & 0.92434 \\
\hline
\end{tabular}

$* \mathrm{k}_{\text {off }}=\mathrm{k}_{\text {ealc }}+0.0004+\left((0.01)^{2}+(1.645)^{2}\left(\sigma_{\mathrm{c}}^{2}+0.002083^{2}\right)\right)^{1 / 2}$ as defined in Section 3.2. This value should be less than 0.95 .

MCNP calculation grid: $\mathrm{mk} 4 \mathrm{~mm}$

\begin{tabular}{|l|l|l|l|l|l|l|l|l|l|l|l|}
\hline & 1 & 2 & 3 & 4 & 5 & 6 & 7 & 8 & 9 & 10 & 11 \\
\hline 1 & & & 3
\end{tabular}

Shaded cells represent water in the basket (universe 2 in the MCNP code), and the unshaded cells represent fuel assemblies (universe 3 in the MCNP code). 
Table 4-11. Single Pass Reactor Fuel in Mark IA Scrap Baskets.

\begin{tabular}{|c|c|c|c|c|}
\hline Case & Configuration analyzed & $\mathrm{k}_{\text {calc }}$ & $\sigma_{\mathrm{c}}$ & $\mathbf{k}_{\text {eff }}{ }^{*}$ \\
\hline spr.1 & $\begin{array}{c}\text { All baskets filled with } 0.95 \mathrm{wt} \%{ }^{235} \mathrm{U} \\
\text { scrap with a cylinder of } 2.1^{235} \mathrm{U} \mathrm{scrap} \\
\text { in the tier 4 basket }\end{array}$ & 0.83514 & 0.00296 & 0.84718 \\
\hline mk1r.2 & Most reactive Mark IA configuration & 0.89017 & 0.00096 & 0.90126 \\
\hline
\end{tabular}

${ }^{*} \mathrm{k}_{\text {off }}=\mathrm{k}_{\text {calo }}+0.0004+\left((0.01)^{2}+(1.645)^{2}\left(\sigma_{\mathrm{c}}{ }^{2}+0.002083^{2}\right)\right)^{1 / 2}$ as defined in Section 3.2. This value should be less than 0.95 .

\subsubsection{Criticality Calculations for the Cold Vacuum Drying Facility}

The results of MCNP computer calculations in Tables 4-12 and 4-13 show the reactivities of loaded MCOs containing either Mark IA or Mark IV fuel and scrap under the operating conditions found in the CVDF. Each MCO is in a separate bay at the CVDF and is isolated from the other MCOs. The MCO and the cask annulus are assumed to be flooded, which is the normal condition for the cask-MCO when it is received at the CVDF.

Table 4-12. Mark IA Multi-Canister Overpack Reactivities During Draining.

\begin{tabular}{|c|c|c|c|c|}
\hline Case & Configuration analyzed & $\mathrm{k}_{\text {calc }}$ & $\sigma_{\mathrm{c}}$ & $\mathbf{k}_{\text {eff }}^{*}$ \\
\hline mklr.2 & Highest $\mathrm{k}_{\text {eff }}$ base case & 0.89017 & 0.00096 & 0.90126 \\
\hline cvd 1.0 & Top scrap basket drained & 0.88691 & 0.00099 & 0.89801 \\
\hline cvd1.1 & $\begin{array}{c}\text { Top scrap basket and tier } 5 \text { fuel basket } \\
\text { drained }\end{array}$ & 0.88788 & 0.00103 & 0.89899 \\
\hline cvd 1.2 & $\begin{array}{c}\text { Top scrap basket and tier } 4 \text { and } 5 \text { fuel } \\
\text { baskets drained }\end{array}$ & 0.88832 & 0.00095 & 0.89941 \\
\hline cvd 1.3 & $\begin{array}{c}\text { Top scrap basket and tier } 3,4 \text { and } 5 \text { fuel } \\
\text { baskets drained }\end{array}$ & 0.88618 & 0.00101 & 0.89728 \\
\hline cvd 1.4 & $\begin{array}{l}\text { Top scrap basket and all fuel baskets } \\
\text { drained }\end{array}$ & 0.88774 & 0.00107 & 0.89886 \\
\hline 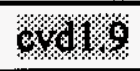 & 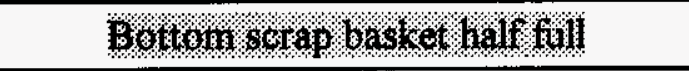 & $0808 \%$ & $0.00 \%$ & $0 \%$ \\
\hline cvd 1.6 & Drained MCO with a flooded annulus & 0.34606 & 0.00061 & 0.35708 \\
\hline cvd 1.8 & Drained MCO with a drained annulus & 0.27991 & 0.00047 & 0.29091 \\
\hline
\end{tabular}

${ }^{*} \mathrm{k}_{\text {eff }}=\mathrm{k}_{\text {calc }}+0.0004+\left((0.01)^{2}+(1.645)^{2}\left(\sigma_{c}{ }^{2}+0.002083^{2}\right)\right)^{1 / 2}$ as defined in Section 3.2. This value should be less than 0.95 .

$$
\mathrm{MCO}=\text { multi-canister overpack }
$$


Table 4-13. Mark IV Multi-Canister Overpack Reactivities During Draining.

\begin{tabular}{|c|c|c|c|c|}
\hline Case & Configuration analyzed & $\mathbf{k}_{\text {calc }}$ & $\sigma_{c}$ & $k_{\text {eff }}^{*}$ \\
\hline mk4ri.4 & Highest $\mathrm{k}_{\text {eff }}$ base case & 0.91540 & 0.00084 & 0.92646 \\
\hline $\operatorname{cvd} 4.0$ & Top scrap basket drained & 0.91231 & 0.00090 & 0.92338 \\
\hline cvd4.1 & $\begin{array}{c}\text { Top scrap basket and tier } 4 \text { fuel basket } \\
\text { drained }\end{array}$ & 0.91372 & 0.00087 & 0.92479 \\
\hline $\operatorname{cvd} 4.2$ & $\begin{array}{c}\text { Top scrap basket and tier } 3 \text { and } 4 \text { fuel } \\
\text { baskets drained }\end{array}$ & 0.91351 & 0.00091 & 0.92459 \\
\hline cvd4.3 & $\begin{array}{c}\text { Top scrap basket and all fuel baskets } \\
\text { drained }\end{array}$ & 0.91204 & 0.00083 & 0.92310 \\
\hline e.ro 49 & Bottom scrap basket half full & 085086 & 000086 & 6.8.103 \\
\hline $\operatorname{cvd} 4.6$ & Drained MCO with a flooded annulus & 0.36980 & 0.00062 & 0.38082 \\
\hline $\operatorname{cvd} 4.8$ & Drained MCO with a drained annulus & 0.31643 & 0.00051 & 0.32743 \\
\hline
\end{tabular}
less than 0.95 .

${ }^{*} \mathrm{k}_{\text {off }}=\mathrm{k}_{\text {ealc }}+0.0004+\left((0.01)^{2}+(1.645)^{2}\left(\sigma_{\mathrm{c}}{ }^{2}+0.002083^{2}\right)\right)^{1 / 2}$ as defined in Section 3.2. This value should be

$$
\mathrm{MCO}=\text { multi-canister overpack }
$$

The highest reactivity for the Mark IA MCO occurs when it is flooded. Reactivity initially decreases, then increases slightly because of the reflection of neutrons by the drained fuel into the flooded fuel regions of the MCO. The maximum reactivity of approximately 0.9 is still well below the 0.95 limit (see Figure 4-6).

The results for the Mark IV MCO are similar to those for the Mark IA MCO with a maximum $\mathrm{k}_{\mathrm{eff}}$ of 0.93 .

\subsubsection{Criticality Calculations for the Canister Storage Building}

The CSB is divided into three vaults surrounded by 1 -ft-thick vertical concrete walls that neutronically isolate the fissionable material in each vault from surrounding vaults. Reactivity of the CSB may be assessed by analyzing a single vault. Two MCOs are placed in each storage tube in a vertical column in a $10 \times 22$ storage array. Steel impact absorbers are installed in the bottom of each storage tube and between each MCO. The operations floor at the top of the tubes is modeled as 5-ft-thick concrete. Each tube is a penetration in the operating floor that extends down to the vault floor. The CSB storage tubes are modeled as a hexagonal grid of 54 in. by 56 in. lattice spacing, 54 in. center-to-center spacing in the 10-tube direction (north-south) and 56 in. center-to-center spacing in the 22-tube direction (east-west). The vault walls are closest along the 22-tube side, but over $10 \mathrm{ft}$ distant on the 10-tube side. MCOs are removed from the 
casks and moved to the CSB storage tubes using the MCO handling machine (MHM), which was modeled as a 10-in.-thick stainless steel tube. Figure 4-7 depicts the CSB layout plan modeled.

The MCNP results in Table 4-14 present the normal array reactivities and MHM reactivities for Mark IA and Mark IV MCOs at the CSB. These results are for normal dry cases of air in and between the storage tubes with water vapor at $0.0012 \mathrm{~g} / \mathrm{cm}^{3}$, and a conservative estimate of twice the expected residual water in the MCO after drying, $0.0051 \mathrm{~g} / \mathrm{cm}^{3}$ of water $(3 \mathrm{~kg}$ of water per MCO). At that density, the intertube moderating effect of water vapor has fallen below the maximum, as discussed in Section 5.2.7.

Table 4-14. Multi-Canister Overpack Reactivities in the Canister Storage Building.

\begin{tabular}{|c|c|c|c|c|}
\hline Case & Configuration analyzed & $\mathbf{k}_{\text {calc }}$ & $\sigma_{c}$ & $\mathbf{k}_{\text {eff }}{ }^{*}$ \\
\hline $\mathrm{csb1.0}$ & Mark IA MCOs in the CSB vault & 0.32167 & 0.00029 & 0.33265 \\
\hline $\mathrm{csb4.0}$ & Mark IV MCOs in the CSB vault & 0.34860 & 0.00034 & 0.35959 \\
\hline $\mathrm{mhm1.0}$ & Mark IA MCO in the MHM & 0.28439 & 0.00047 & 0.29539 \\
\hline $\mathrm{mhm1.2}$ & $\begin{array}{c}\text { Mark IA MCO lowered 2.5 } \mathrm{ft} \text { through the } \\
\text { floor }\end{array}$ & 0.28706 & 0.00048 & 0.29806 \\
\hline $\mathrm{mhm1.4}$ & $\begin{array}{c}\text { Mark IA MCO lowered 5 } \mathrm{ft} \text { through the } \\
\text { floor }\end{array}$ & 0.31336 & 0.00057 & 0.32437 \\
\hline $\mathrm{mhm4.0}$ & Mark IV MCO in the MHM & 0.31950 & 0.00052 & 0.33051 \\
\hline $\mathrm{mhm4.2}$ & $\begin{array}{c}\text { Mark IV MCO lowered 2.5 } \mathrm{ft} \text { through the } \\
\text { floor }\end{array}$ & 0.32153 & 0.00056 & 0.33254 \\
\hline $\mathrm{mhm4.4}$ & $\begin{array}{c}\text { Mark IV MCO lowered 5 } \mathrm{ft} \text { through the } \\
\text { floor }\end{array}$ & 0.34161 & 0.00061 & 0.35263 \\
\hline
\end{tabular}
less than 0.95 .

$* \mathrm{k}_{\text {eff }}=\mathrm{k}_{\text {ealc }}+0.0004+\left((0.01)^{2}+(1.645)^{2}\left(\sigma_{c}{ }^{2}+0.002083^{2}\right)\right)^{1 / 2}$ as defined in Section 3.2. This value should be

$\mathrm{MCO}=$ multi-canister overpack.

MHM = multi-canister overpack handling machine.

While it is being removed from or inserted into a storage tube, the MCO is closely surrounded along part of its length by the floor slab. A single MCO has been modeled in the MHM with stainless steel directly around and above it and with the 5-ft-thick concrete floor below it. The most reactive condition occurs when the MCO has been lowered $5 \mathrm{ft}$ and the lower scrap basket is level with the bottom of the floor. In all cases, the values for $\mathrm{k}_{\text {eff }}$ are less than 0.36 . These results show that, under normal conditions, there is a significant reactivity margin for criticality safety when the MCO is being moved. 


\subsubsection{Loading of the Long-Length Mark IA Assemblies in Mark IV Fuel Baskets}

The $\mathrm{K}$ West Basin contains 12 Mark IA assemblies and 2 inner elements that are 26.1 in. long that will be handled as Mark IV inner elements. The 12 intact assemblies and 2 inner elements will be loaded into Mark IV fuel baskets. This is not the same situation as misloading Mark IA fuel in a Mark IV fuel basket because misloaded fuel would be a maximum of 20.9 in. long (see Section 5.2.3). For this analysis, 18 26.1-in.-long Mark IA fuel assemblies were loaded either in the center middle or outer row of a Mark IV fuel basket. The results are contained in Tables 4-15, 4-16, and 4-17. These results show that the 12 long-length Mark IA assemblies may be loaded in any fuel basket, in any row.

Table 4-15. Calculation Results for Multi-Canister Overpacks Containing

Long-Length Mark IA Fuel Assemblies in the Center of Mark IV Baskets.

\begin{tabular}{|c|c|c|c|c|}
\hline Case & Location & $\mathrm{k}_{\text {calc }}$ & $\sigma_{\mathrm{c}}$ & $\mathrm{k}_{\text {eff }}{ }^{\mathrm{a}}$ \\
\hline $18 \mathrm{rc} .0^{\mathrm{b}, \mathrm{d}}$ & Cask-MCO in the K Basins & 0.91355 & 0.00089 & 0.92462 \\
\hline $18 \mathrm{rc} .1^{\mathrm{b}, \mathrm{d}}$ & Cask-MCO at the CVDF & 0.91312 & 0.00087 & 0.92419 \\
\hline $18 \mathrm{rc} .3^{\mathrm{c}, \mathrm{d}}$ & Cask-MCO in the K Basins & 0.91600 & 0.00089 & 0.92707 \\
\hline $18 \mathrm{rc} .4^{\mathrm{c}, \mathrm{d}}$ & Cask-MCO at the CVDF & 0.91519 & 0.00082 & 0.92625 \\
\hline $18 \mathrm{rc} .6^{\mathrm{c}, \mathrm{e}}$ & Cask-MCO in the K Basins & 0.91412 & 0.00092 & 0.92520 \\
\hline $18 \mathrm{rc} .7^{\mathrm{c}, \mathrm{e}}$ & Cask-MCO at the CVDF & 0.91526 & 0.00092 & 0.92634 \\
\hline $18 \mathrm{rc} .9^{\mathrm{b}, \mathrm{e}}$ & Cask-MCO in the K Basins & 0.91331 & 0.00083 & 0.92437 \\
\hline $18 \mathrm{rc} .16^{\mathrm{b}, \mathrm{e}}$ & Cask-MCO at the CVDF & 0.91313 & 0.00083 & 0.92419 \\
\hline $18 \mathrm{rc} .10^{\mathrm{b}, \mathrm{f}}$ & Cask-MCO in the K Basins & 0.91341 & 0.00099 & 0.92451 \\
\hline $18 \mathrm{rc} .14^{\mathrm{b}, \mathrm{f}}$ & Cask-MCO at the CVDF & 0.91429 & 0.00091 & 0.92537 \\
\hline $18 \mathrm{rc} .11^{\mathrm{c}, \mathrm{f}}$ & Cask-MCO in the K Basins & 0.91536 & 0.00095 & 0.92645 \\
\hline $18 \mathrm{rc} .12^{\mathrm{c}, \mathrm{f}}$ & Cask-MCO at the CVDF & 0.91498 & 0.00094 & 0.92606 \\
\hline
\end{tabular}

${ }^{*} \mathrm{k}_{\text {sff }}=\mathrm{k}_{\text {calo }}+0.0004+\left((0.01)^{2}+(1.645)^{2}\left(\sigma_{\mathrm{o}}{ }^{2}+0.002083^{2}\right)\right)^{1 / 2}$ as defined in Section 3.2. This value should be less than 0.95 .

'Fuel baskets contain an inner element location in position 4,5.

-Fuel baskets contain an inner element location in position 3,6 .

Mark IA assemblies in the middle fuel basket.

Mark IA assemblies in the lower fuel basket next to the scrap basket.

Mark IA assemblies in the upper fuel basket next to the scrap basket. 
Table 4-16. Calculation Results for Multi-Canister Overpacks Containing Long-Length Mark IA Fuel Assemblies in the Middle Row of Mark IV Baskets.

\begin{tabular}{|c|c|c|c|c|}
\hline Case & Location & $\mathrm{k}_{\text {calc }}$ & $\sigma_{\mathrm{c}}$ & $k_{\text {eff }}{ }^{*}$ \\
\hline $18 \mathrm{rm} \cdot 0^{\mathrm{b}, \mathrm{d}}$ & Cask-MCO in the $\mathrm{K}$ Basins & 0.91407 & 0.00086 & 0.92514 \\
\hline $18 \mathrm{rm} \cdot 1^{\mathrm{b}, \mathrm{d}}$ & Cask-MCO at the CVDF & 0.91464 & 0.00093 & 0.92572 \\
\hline $18 \mathrm{rm} \cdot 3^{\mathrm{c}, \mathrm{d}}$ & Cask-MCO in the K Basins & 0.91271 & 0.00088 & 0.92378 \\
\hline $18 \mathrm{rm} \cdot 4^{\mathrm{c}, \mathrm{d}}$ & Cask-MCO at the CVDF & 0.91189 & 0.00084 & 0.92295 \\
\hline $18 \mathrm{rm} \cdot 6^{\mathrm{c}, \mathrm{o}}$ & Cask-MCO in the K Basins & 0.91513 & 0.00091 & 0.92621 \\
\hline $18 \mathrm{rm} .7^{\mathrm{c}, \mathrm{e}}$ & Cask-MCO at the CVDF & 0.91408 & 0.00090 & 0.92515 \\
\hline $18 \mathrm{rm} \cdot 9^{\mathrm{b}, \mathrm{e}}$ & Cask-MCO in the K Basins & 0.91271 & 0.00086 & 0.92378 \\
\hline $18 \mathrm{rm} .16^{\mathrm{b}, \mathrm{e}}$ & Cask-MCO at the CVDF & 0.91394 & 0.00103 & 0.92505 \\
\hline $18 \mathrm{rm} \cdot 10^{b, f}$ & Cask-MCO in the $\mathrm{K}$ Basins & 0.91323 & 0.00084 & 0.92429 \\
\hline $18 \mathrm{rm} .14^{\mathrm{b}, \mathrm{f}}$ & Cask-MCO at the CVDF & 0.91208 & 0.00099 & 0.92318 \\
\hline $18 \mathrm{rm} .11^{\text {a,f }}$ & Cask-MCO in the K Basins & 0.91239 & 0.00079 & 0.92344 \\
\hline $18 \mathrm{rm} .12^{\mathrm{c}, \mathrm{f}}$ & Cask-MCO at the CVDF & 0.91224 & 0.00092 & 0.92332 \\
\hline
\end{tabular}

${ }^{*} \mathrm{k}_{\mathrm{aff}}=\mathrm{k}_{\text {oalc }}+0.0004+\left((0.01)^{2}+(1.645)^{2}\left(\sigma_{\mathrm{c}}{ }^{2}+0.002083^{2}\right)\right)^{1 / 2}$ as defined in Section 3.2. This value should be less than 0.95 .

${ }^{b}$ Fuel baskets contain an inner element location in position 4,5.

Fuel baskets contain an inner element location in position 3,6.

Mark IA assemblies in the middle fuel basket.

"Mark IA assemblies in the lower fuel basket next to the scrap basket.

"Mark IA assemblies in the upper fuel basket next to the scrap basket. 
Table 4-17 Calculation Results for Multi-Canister Overpacks Containing Long-Length Mark IA Fuel Assemblies in the Outer Row of Mark IV Baskets.

\begin{tabular}{|c|c|c|c|c|}
\hline Case & Location & $\mathbf{k}_{\text {calc }}$ & $\sigma_{c}$ & $\mathbf{k}_{\text {eff }}{ }^{*}$ \\
\hline $18 \mathrm{rp} .0^{\mathrm{b}, \mathrm{d}}$ & Cask-MCO in the K Basins & 0.91335 & 0.00089 & 0.92442 \\
\hline $18 \mathrm{rp} .1^{\mathrm{b}, \mathrm{d}}$ & Cask-MCO at the CVDF & 0.91545 & 0.00083 & 0.92651 \\
\hline $18 \mathrm{rp} .3^{\mathrm{c}, \mathrm{d}}$ & Cask-MCO in the K Basins & 0.91462 & 0.00092 & 0.92570 \\
\hline $18 \mathrm{rp} .4^{\mathrm{c}, \mathrm{d}}$ & Cask-MCO at the CVDF & 0.91516 & 0.00087 & 0.92623 \\
\hline $18 \mathrm{rp} .6^{\mathrm{c}, \mathrm{e}}$ & Cask-MCO in the K Basins & 0.91409 & 0.00086 & 0.92516 \\
\hline $18 \mathrm{rp} .7^{\mathrm{c}, \mathrm{e}}$ & Cask-MCO at the CVDF & 0.91410 & 0.00088 & 0.92517 \\
\hline $18 \mathrm{rp} .9^{\mathrm{b}, \mathrm{e}}$ & Cask-MCO in the K Basins & 0.91464 & 0.00088 & 0.92571 \\
\hline $18 \mathrm{rp} .16^{\mathrm{b}, \mathrm{e}}$ & Cask-MCO at the CVDF & 0.91122 & 0.00083 & 0.92228 \\
\hline $18 \mathrm{rp} .10^{\mathrm{b}, \mathrm{f}}$ & Cask-MCO in the K Basins & 0.91409 & 0.00087 & 0.92516 \\
\hline $18 \mathrm{rp} .14^{\mathrm{b}, \mathrm{f}}$ & Cask-MCO at the CVDF & 0.91401 & 0.00087 & 0.92508 \\
\hline $18 \mathrm{rp} .11^{\mathrm{c}, \mathrm{f}}$ & Cask-MCO in the K Basins & 0.91396 & 0.00093 & 0.92504 \\
\hline $18 \mathrm{rp} .12^{\mathrm{c}, \mathrm{f}}$ & Cask-MCO at the CVDF & 0.91464 & 0.00090 & 0.92571 \\
\hline
\end{tabular}

$* \mathrm{k}_{\text {off }}=\mathrm{k}_{\text {calo }}+0.0004+\left((0.01)^{2}+(1.645)^{2}\left(\sigma_{\mathrm{c}}{ }^{2}+0.002083^{2}\right)\right)^{1 / 2}$ as defined in Section 3.2. This value should be less than 0.95 .

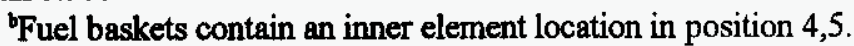

Fuel baskets contain an inner element location in position 3,6.

Mark IA assemblies in the middle fuel basket.

Mark IA assemblies in the lower fuel basket next to the scrap basket.

Mark IA assemblies in the upper fuel basket next to the scrap basket.

\subsubsection{The Effects of Loading Mark IA Outer Elements in Mark IA Fuel Baskets, With No Inner Elements}

Loading a Mark IA fuel basket with only Mark IA outer elements may affect the $\mathrm{k}_{\text {eff }}$ of the MCO. This is because the spacing of the elements in the basket is closer to the optimal spacing for outer elements (Schwinkendorf 1995) and the inner element is replaced by moderator. A series of calculations were performed to show that effect is to lower the $k_{\text {eff }}$ because the reduction in ${ }^{235} \mathrm{U}$ mass in the basket containing no inner elements compensates for the increased moderation and the more optimal spacing. Therefore, it is acceptable to load Mark IA fuel baskets with only Mark IA outer elements, and to load these baskets into an MCO either with other fuel baskets containing intact assemblies or with other fuel baskets containing only outer elements. In all cases, the model included two Mark IA scrap baskets and, when fuel baskets containing intact fuel were included, they were partially loaded in accordance with the highest $\mathbf{k}_{\text {eff }}$ base case. 
Table 4-18 Calculation Results for Multi-Canister Overpacks Containing Mark IA Fuel Baskets Loaded with only Mark IA Outer Elements.

\begin{tabular}{|c|c|c|c|c|}
\hline Case & Configuration analyzed & $\mathbf{k}_{\text {calc }}$ & $\sigma_{c}$ & $\mathbf{k}_{\text {eff }}$ \\
\hline mklro.01 & $\begin{array}{l}\text { The basket containing outer elements } \\
\text { loaded in tier } 2 \text { next to the scrap basket }\end{array}$ & 0.88727 & 0.00096 & 0.89836 \\
\hline mklro. 02 & $\begin{array}{l}\text { The basket containing outer elements } \\
\text { loaded in tier } 3\end{array}$ & 0.88668 & 0.00099 & 0.89778 \\
\hline mk1ro.03 & $\begin{array}{l}\text { The basket containing outer elements } \\
\text { loaded in tier } 4\end{array}$ & 0.88679 & 0.00105 & 0.89790 \\
\hline mklro.04 & $\begin{array}{l}\text { The basket containing outer elements } \\
\text { loaded in tier } 5 \text { next to the top } \\
\text { scrap basket }\end{array}$ & 0.88721 & 0.00091 & 0.89829 \\
\hline mkl ro. 05 & $\begin{array}{c}\text { Two baskets containing outer elements } \\
\text { loaded adjacent to each other in } \\
\text { tiers } 2 \text { and } 3\end{array}$ & 0.88737 & 0.00106 & 0.89848 \\
\hline mklro.06 & $\begin{array}{c}\text { Two baskets containing outer elements } \\
\text { loaded adjacent to each other in } \\
\text { tiers } 3 \text { and } 4\end{array}$ & 0.88356 & 0.00101 & 0.89466 \\
\hline mklro.07 & $\begin{array}{c}\text { Two baskets containing outer elements } \\
\text { loaded adjacent to each other in } \\
\text { locations } 4 \text { and } 5\end{array}$ & 0.88741 & 0.00101 & 0.89851 \\
\hline mklro.08 & $\begin{array}{l}\text { Two baskets containing outer elements } \\
\text { loaded in tiers } 2 \text { and } 5\end{array}$ & 0.88650 & 0.00103 & 0.89761 \\
\hline mklro.09 & $\begin{array}{l}\text { Three baskets containing outer elements } \\
\text { loaded in tiers } 2,3 \text {, and } 4\end{array}$ & 0.88323 & 0.00111 & 0.89436 \\
\hline mklro.0 & $\begin{array}{l}\text { Four fuel baskets containing outer } \\
\text { elements }\end{array}$ & 0.88750 & 0.00097 & 0.89859 \\
\hline
\end{tabular}


Figure 4-1. Input Model for Normal Case - Mark IA.

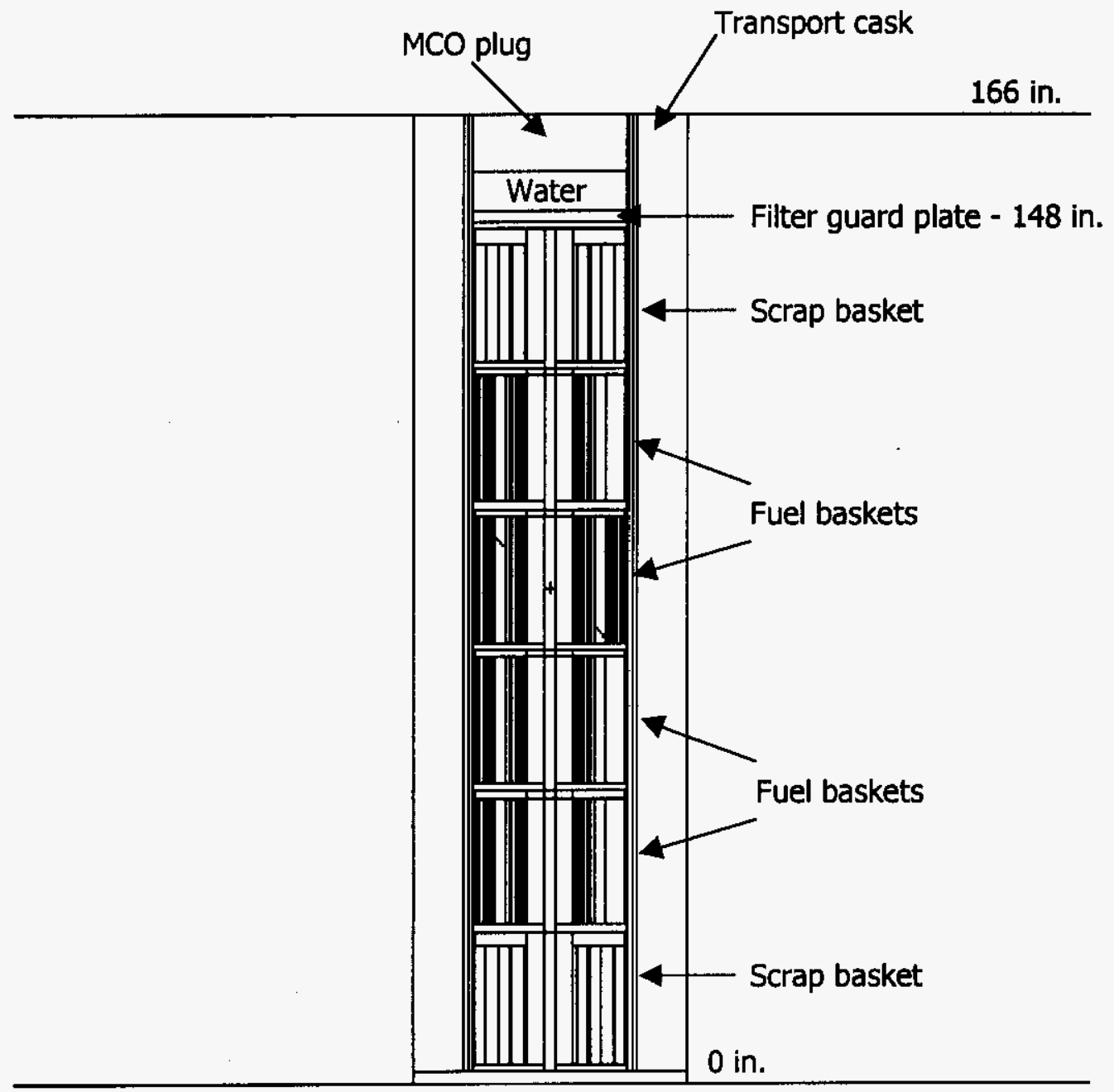

Mark IA Normal Configuration 
Figure 4-2. Input Model for Normal Case - Mark IV.

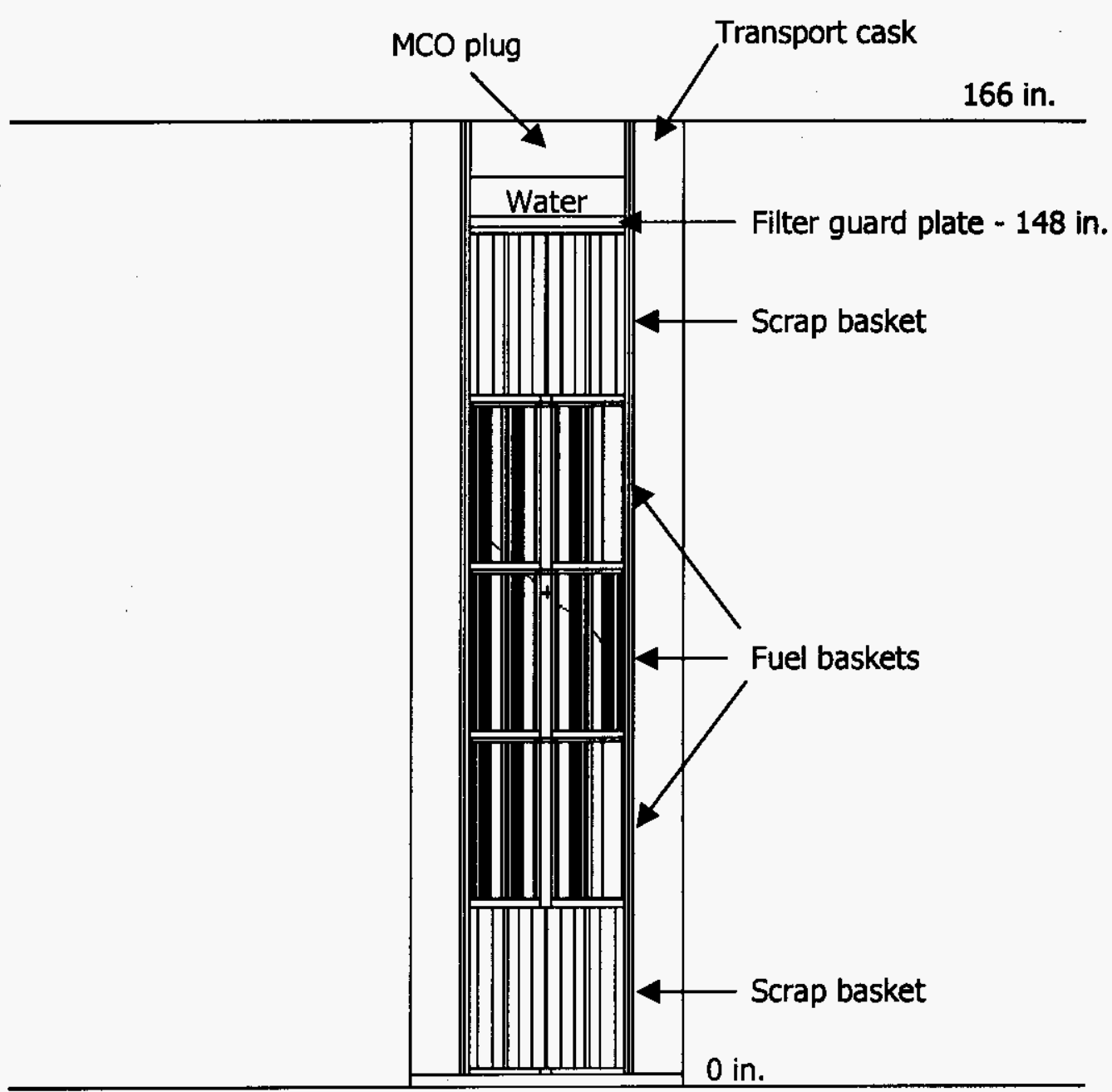

Mark IV Normal Configuration 


\section{HNF-SD-SNF-CSER-005 REV 5}

Figure 4-3. MCNP Mark IA Fuel Basket Grid.

\begin{tabular}{|c|c|c|c|c|c|c|c|c|c|c|c|}
\hline & 1 & 2 & 3 & 4 & 5 & 6 & 7 & 8 & 9 & 10 & 11 \\
\hline 1 & & & & & & & & & & & \\
\hline 2 & & & & & & & & & & & \\
\hline 3 & & & & & & & & & & & \\
\hline 4 & & & & & & & & & & & \\
\hline 5 & & & & & & & & & & & \\
\hline 6 & & & & & & & & & & & \\
\hline 7 & & & & & & & & & & & \\
\hline 8 & & & & & & & & & & & \\
\hline 9 & & & & & & & & & & & \\
\hline 10 & & & & & & & & & & & \\
\hline 11 & & & & & & & & & & & \\
\hline
\end{tabular}

Shaded cells represent water in the basket (universe 2 in the MCNP code), and the unshaded cells represent fuel assemblies (universe 3 in the MCNP code). 
Figure 4-4. Maximum Reactivity Loading Arrangement for Mark IA Fuel in Multi-Canister Overpack.

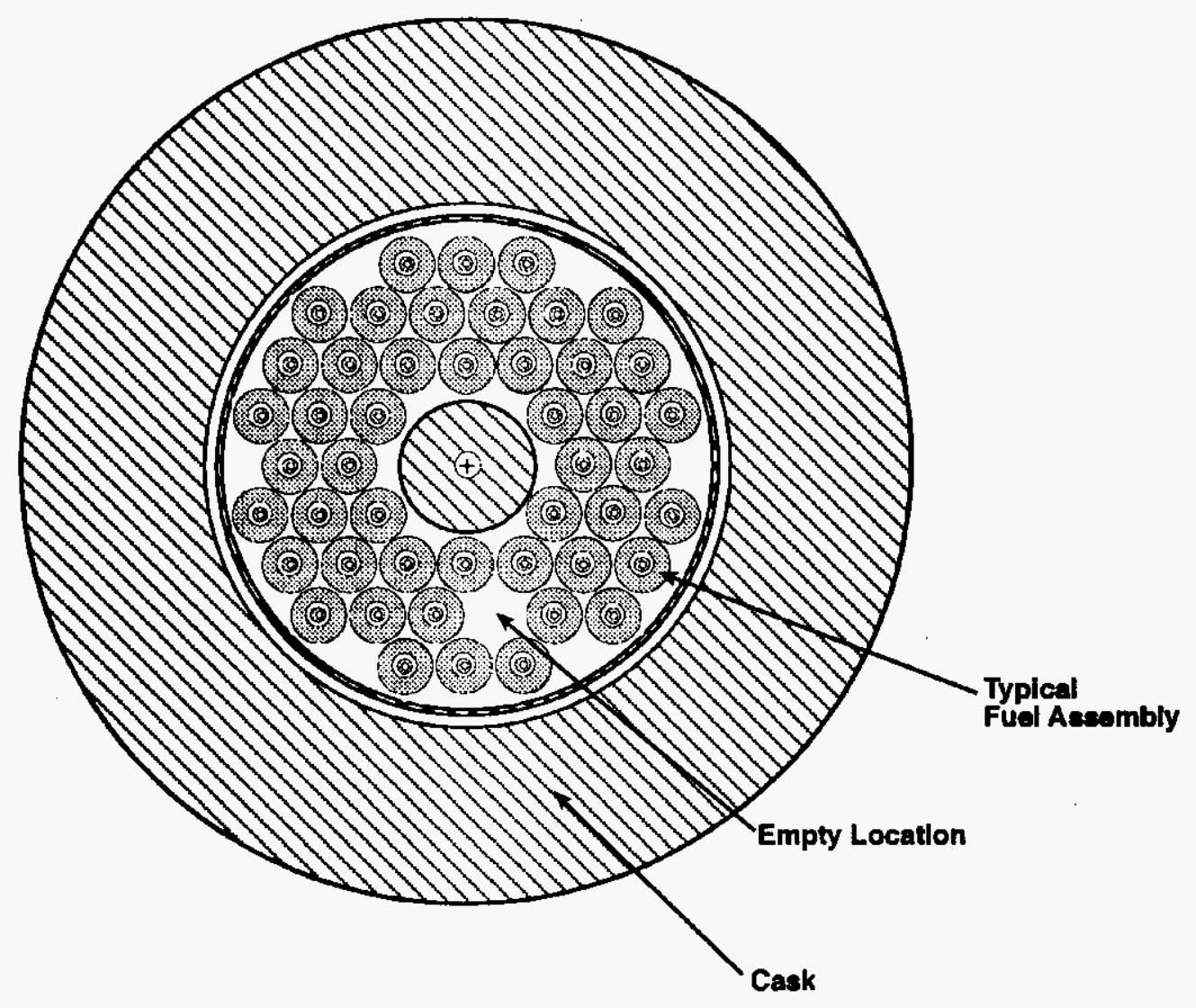

Mark IA Basket

steel

Fuel

H99090073.3R4

SNFP 
Figure 4-5. Maximum Reactivity Loading Arrangement for Mark IV Fuel in Multi-Canister Overpack.

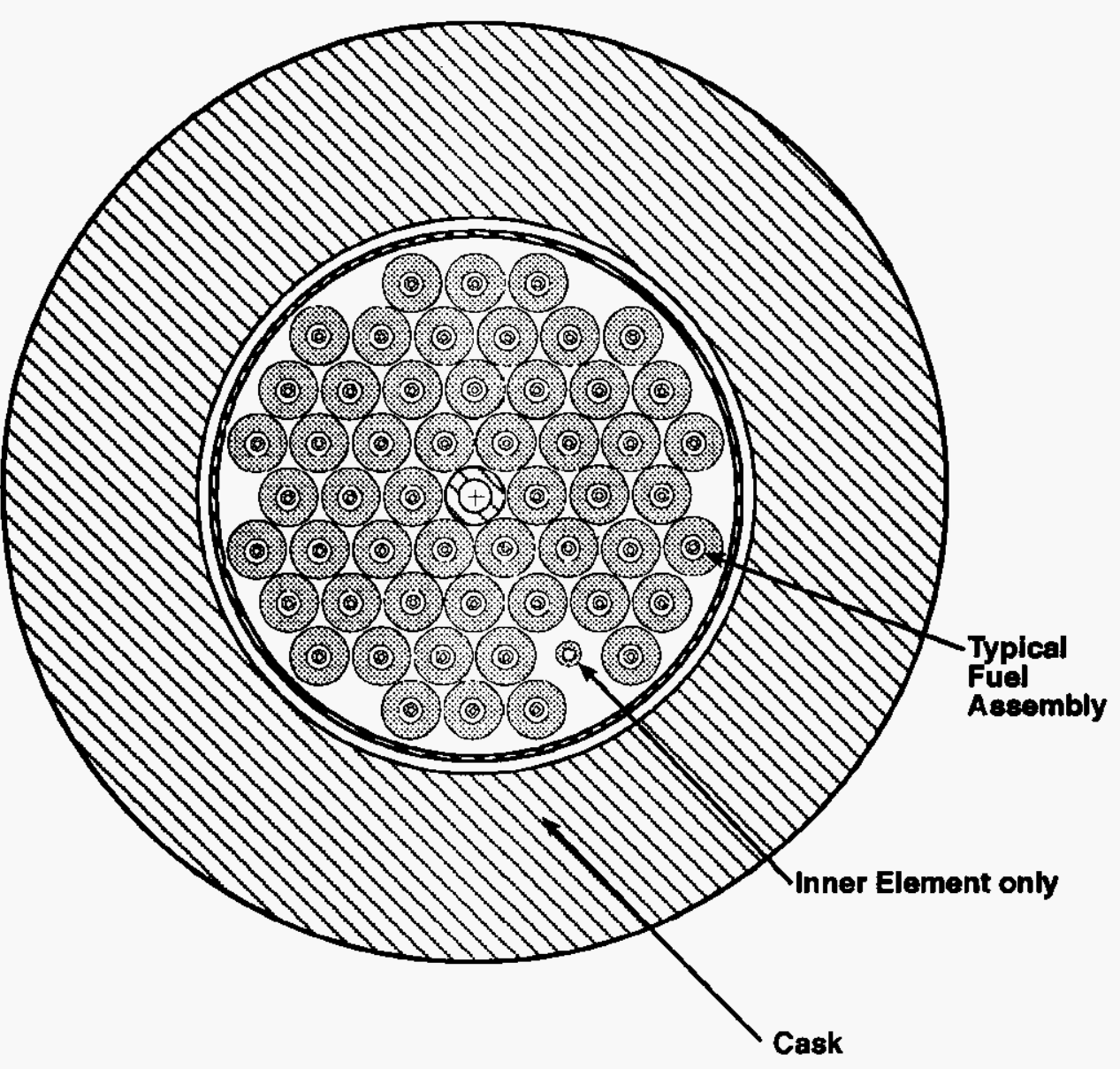

Mark IV Basket

Stoel

Fuel

H99000073.1R7
SNFP 


\section{HNF-SD-SNF-CSER-005 REV 5}

Figure 4-6. K-Effective During Draining of the Multi-Canister Overpack.

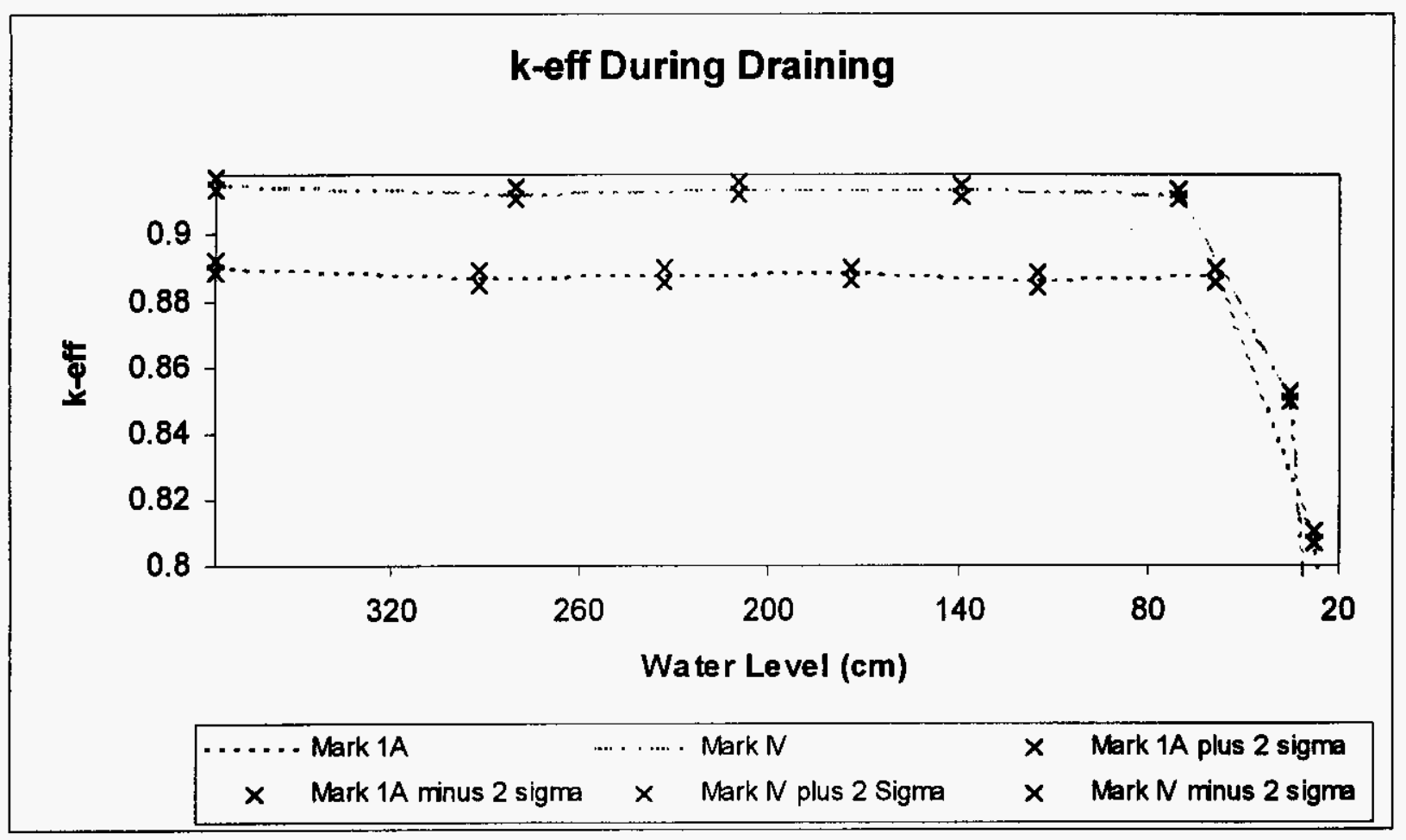




\section{HNF-SD-SNF-CSER-005 REV 5}

Figure 4-7. Canister Storage Building Array and Storage Tube Layout.

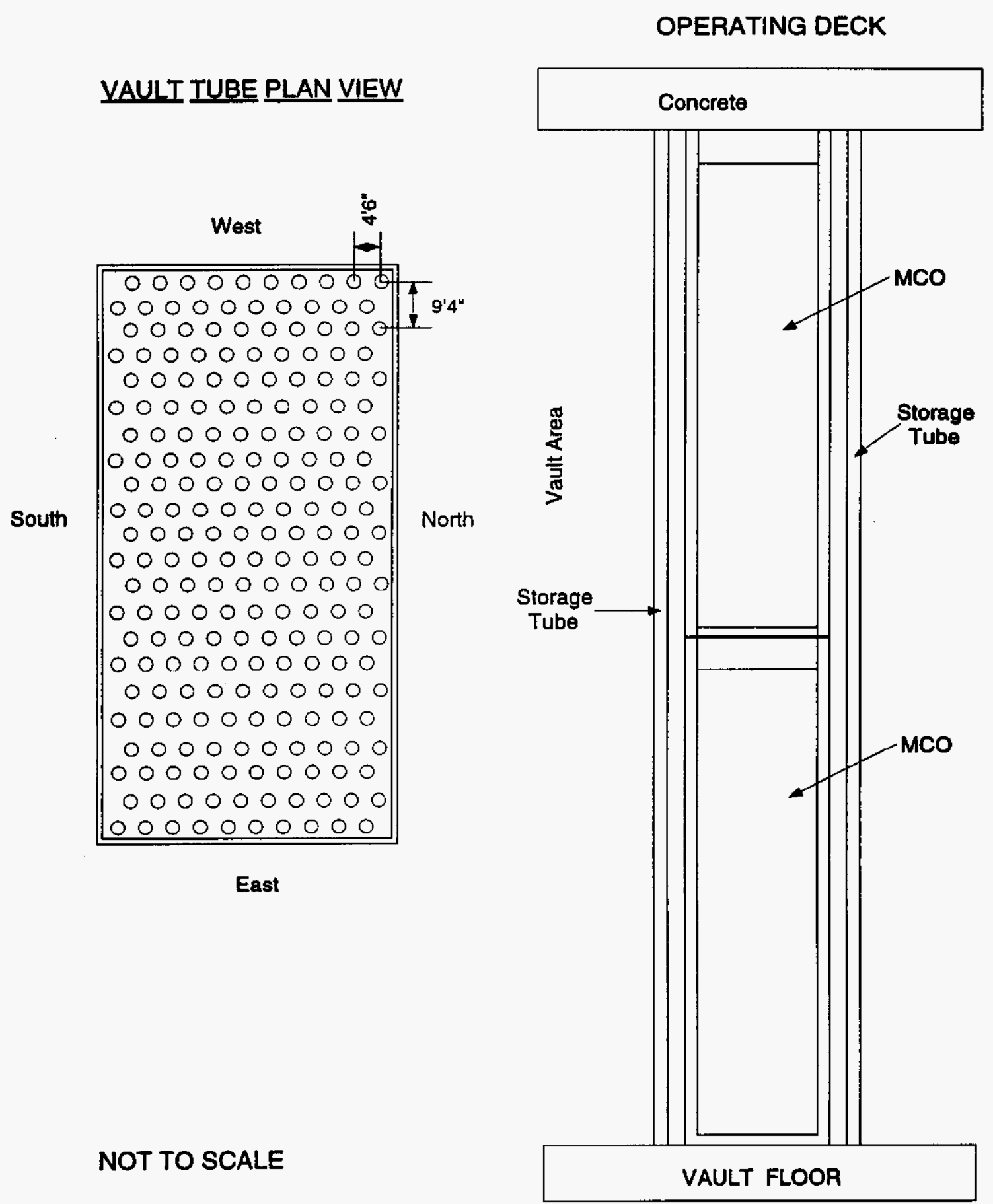

Note: The impact absorber in the bottom of the tube is 36 in. tall, and the intermediate impact absorber is 18 in. tall. The impact absorbers are not shown on this figure. 


\subsection{CONTINGENCY ANALYSIS}

In preparation for performing the analysis for this CSER, significant thought went into trying to determine what normal MCO loadings could be expected; what normal loading range would provide operating flexibility and margin and, consequently, the minimal number of limitations; and what accident conditions were possible.

\subsection{POTENTIAL ERROR AND FAILURE SITUATIONS}

HNF-PRO-539, Appendix A, "Potential Error/Failure Situations" identifies areas where criticality problems may develop. An evaluation of each of the items on the list is discussed below as it applies to the MCO.

Item 1. Equipment's dimension variation due to

- Fabrication tolerances

- Mechanical disarrangement (e. g., earthquake, drop)

- Chemical attack (corrosion)

- Thermal effect (fire)

- Accidental pressurization effects.

Comment: Appendix B discusses the effects of fabrication tolerances of fuel assemblies on reactivity. The appendix also discusses the effects of fuel corrosion and its products accumulating in the bottom basket of the MCO. Safety-class design features ensure the fuel is maintained in a safe configuration. As the MCO is drained, its internal temperature is controlled, removing heat to the water circulating through the cask annulus. A degradation or loss of cooling could cause a thermal runaway inside the MCO. HNF-SD-SNF-CN-023, Thermal Analysis of Cold Vacuum Drying of Spent Nuclear Fuel (Piepho and Crowe 1998), discuses the consequences of a thermal runaway reaction and concludes that the fuel could exceed temperature limits but that safety-class systems and components prevent thermal runaway reactions and thus the reactivity of the MCO is not impacted by this accident scenario. External fires are analyzed in HNF-SD-TP-SARP-017, Safety Analysis Report for Packaging (Onsite) Multicanister Overpack Cask, Appendix B, Section 8.5 (Edwards 1997). The analysis shows that the MCO can withstand a fire and not have a thermal runaway of the fuel. At the CVDF, the fuel is always contained in the MCO except for the small amount of particulate released to the process water conditioning system. The amount of fissionable material released is too small to present a criticality hazard (Nelson 1999). At the $\mathrm{CSB}$, there are no combustible materials in the storage,vaults and fires are unlikely. Both the CVDF and the CSB are designated as firefighting category B facilities. The only time the MCO is pressurized is during draining at the CVDF. A rupture disk on the MCO prevents overpressurization from the time the MCO is sealed at the K Basins until the drying process has been completed. Since the models assume optimal moderation and flooded conditions, changes in internal MCO pressure will have no affect on criticality. 
Item 2. Excesses in mass or volume from errors in

- Segregating materials of different enrichments

- Overbatching

- Analysis error

- Maintaining uniformity of materials

- Loss of control of the number or size of containers.

Comment: HNF-SD-SNF-CSER-010 (Kessler and Peck 1999) and operating procedures (when available) define requirements for correctly loading materials into baskets and loading baskets into the MCO. Loading and handling of the SPR fuel is defined in HNF-SD-SNF-CSER-010 (Kessler and Peck 1999). Over-batching has been analyzed. Limits have been established to control the amount of scrap that can be loaded into an MCO basket. Misloading of the baskets has been analyzed (see Section 5.2.4). Loading the 12 26.1-in.-long Mark IA assemblies in a Mark IV basket has also been analyzed and loading of the Mark IA material in the K East Basin has been evaluated. Since there is no chemical processing, analysis errors are unlikely.

Item 3. Excess of mass in a non-safe geometry vessel resulting from

- Cross connections

- Unauthorized piping changes

- Valve leakage.

Comment: The MCO has been evaluated (see Section 5.2.3) to ensure that excess mass will not lead to inadvertent criticality. In all cases, limits and the need for multiple contingencies to occur provide adequate safety margin. There is no chemical processing and no systems associated with the MCO in which cross connections, leaking valves, and unauthorized piping changes could be a problem.

Item 4. Changes in geometry resulting from

- Spilling or leakage

- Mechanical compacting

- Rubblizing.

Comment: The MCO has been evaluated (see Section 5.2.2) for design basis drop accidents in which spills of fuel or mechanical compacting or settling could occur. The design of the MCO, MCO cover, and Mark IA basket ensure criticality safety is maintained.

Item 5. Changes in reflection from

- Flooding

- Added shielding (dose reduction campaign). 
Comment: All MCO loading activities occur under water and have been analyzed assuming optimal moderation and maximum reflection. No additional shielding is planned. Draining the cask-MCO annulus with a flooded MCO is a contingency for CVDF and has been analyzed (see Section 5.2.1). Calculations for the CSB include the contingencies of flooding the storage vaults, the storage tubes, and the MCOs internally. The results of these calculations are presented in Sections 5.2.5 through 5.2.7.

Item 6. Changes in concentration from

- Precipitation

- Accumulation

- Evaporation

- Other process upsets.

Comment: All analyses have been performed assuming the only change in physical form of the fuel is due to corrosion after cleaning and drying. These corrosion products are assumed to fall from the upper baskets and accumulate in the lower baskets. Results of these analyses are discussed in Appendix B. Precipitation and evaporation are not problems because the material is not in solution.

Item 7. Increased interaction from

- Collapse of shelving or spacers

- Material in transit

- Excessive additions to array

- Changes in relative position of units by flooding and floating units

- Spacing error.

Comment: Transport limits are specified in the HNF-SD-TP-SARP-017 (Edwards 1997). Spacing errors and additions to the storage arrays are eliminated by the design of the shipping cask and the design of the CSB storage tubes and the storage arrays. Section 5.2.9 discusses the results of loading two MCOs in a storage tube without an intermediate impact absorber.

Item 8. Changes in moderation from

- Inleakage

- Absorption by hygroscopic material

- Condensation

- Inadequate drying

- Fire fighting activity

- Evaporation

- Precipitation. 
Comment: All MCO normal and abnormal conditions have been analyzed assuming fully moderated and optimized conditions. Removing water from the MCO will reduce moderation and $\mathrm{k}_{\text {eff }}$. Section 5.2.10 discusses flooding of the CSB sampling/weld station with glycol.

\subsection{CONTINGENCY ANALYSIS}

Contingencies considered for the MCO include the following:

- Receipt at the CVDF of an MCO in a cask with a drained annulus

- Design basis drops during MCO loading in the K Basins and during CSB operations

- Loading a misloaded basket into an MCO

- Misloading an MCO with an additional scrap basket

- Misloading scrap baskets within the MCO (i.e., loading scrap baskets in the wrong tiers)

- Flooding an $\mathrm{MCO}$ at the CSB

- Flooding a CSB storage tube

- Flooding the CSB storage array

- Handling a flooded MCO with the MHM

- Loading an $\mathrm{MCO}$ in a storage tube without an intermediate impact absorber

- Flooding the weld or sample station with glycol.

\subsubsection{Receipt of a Multi-Canister Overpack in a Cask with a Drained Annulus}

The shipping cask is filled with clean water, and the $\mathrm{MCO}$ is filled with deionized basin water at the $\mathrm{K}$ Basins prior to loading. The cask-MCO is contained in an immersion pail that has seals to maintain the cask and annulus water. The clean water stays in the cask annulus where it is used for temperature control until the MCO is drained at the CVDF. Should the annulus be drained before the cask-MCO is received at the CVDF, the $\mathrm{k}_{\text {eff }}$ will remain below 0.95 . This is shown by cases cvd1.7 and cvd4.7 in Table 5-1. Also included in the table are the results for an MCO containing the long-length Mark IA fuel assemblies in the Mark IV fuel basket. 
Table 5-1. Calculation Results for Multi-Canister Overpacks Containing Long-Length Mark IA Fuel Assemblies in Mark IV Baskets with a Drained Annulus. (2 sheets)

\begin{tabular}{|c|c|c|c|c|}
\hline Case & MCO configuration & $\mathrm{k}_{\text {calc }}$ & $\sigma_{\mathrm{c}}$ & $k_{\text {effi }}^{a}$ \\
\hline $\operatorname{cvd} 1.7$ & $\begin{array}{l}2 \text { scrap baskets and } 4 \text { partially loaded fuel } \\
\text { baskets in a Mark IA MCO }\end{array}$ & 0.90154 & 0.00096 & 0.91263 \\
\hline cvd4.7 & $\begin{array}{l}2 \text { scrap baskets and } 3 \text { partially loaded fuel } \\
\text { baskets in a Mark IV MCO }\end{array}$ & 0.92152 & 0.00088 & 0.93259 \\
\hline $18 \mathrm{rc} .2^{\mathrm{b}}$ & $\begin{array}{l}\text { Mark IA assemblies in the center of the } \\
\text { central basket }\end{array}$ & 0.92155 & 0.00090 & 0.93262 \\
\hline $18 \mathrm{rc} .5^{\circ}$ & $\begin{array}{l}\text { Mark IA assemblies in the center of the } \\
\text { central basket }\end{array}$ & 0.92091 & 0.00089 & 0.93198 \\
\hline $18 \mathrm{rc} .8^{\mathrm{c}}$ & $\begin{array}{l}\text { Mark IA assemblies in the center of the } \\
\text { lower basket }\end{array}$ & 0.92303 & 0.00079 & 0.93408 \\
\hline $18 \mathrm{rc} .17^{\mathrm{b}}$ & $\begin{array}{l}\text { Mark IA assemblies in the center of the } \\
\text { upper basket }\end{array}$ & 0.92388 & 0.00097 & 0.93497 \\
\hline $18 \mathrm{rc} .15^{\mathrm{b}}$ & $\begin{array}{l}\text { Mark IA assemblies in the center of the } \\
\text { lower basket }\end{array}$ & 0.92453 & 0.00087 & 0.93560 \\
\hline $18 \mathrm{rc} .13^{\mathrm{c}}$ & $\begin{array}{c}\text { Mark IA assemblies in the center of the } \\
\text { upper basket }\end{array}$ & 0.92356 & 0.00091 & 0.93464 \\
\hline $18 \mathrm{rm} \cdot 2^{\mathrm{b}}$ & $\begin{array}{l}\text { Mark IA assemblies in the middle row of } \\
\text { the central basket }\end{array}$ & 0.92123 & 0.00084 & 0.93229 \\
\hline $18 \mathrm{rm} \cdot 5^{\mathrm{c}}$ & $\begin{array}{l}\text { Mark IA assemblies in the middle row of } \\
\text { the central basket }\end{array}$ & 0.92221 & 0.00085 & 0.93327 \\
\hline $18 \mathrm{rm} .8^{\mathrm{c}}$ & $\begin{array}{l}\text { Mark IA assemblies in the middle row of } \\
\text { the lower basket }\end{array}$ & 0.92129 & 0.00090 & 0.93236 \\
\hline $18 \mathrm{rm} .15^{\mathrm{b}}$ & $\begin{array}{l}\text { Mark IA assemblies in the middle row of } \\
\text { the lower basket }\end{array}$ & 0.92208 & 0.00093 & 0.93316 \\
\hline $18 \mathrm{rm} .17^{\mathrm{b}}$ & $\begin{array}{l}\text { Mark IA assemblies in the middle row of } \\
\text { the upper basket }\end{array}$ & 0.92250 & 0.00085 & 0.93356 \\
\hline $18 \mathrm{rm} \cdot 13^{\mathrm{c}}$ & $\begin{array}{l}\text { Mark IA assemblies in the middle row of } \\
\text { the upper basket }\end{array}$ & 0.92202 & 0.00085 & 0.93308 \\
\hline $18 \mathrm{rp} .2^{b}$ & $\begin{array}{l}\text { Mark IA assemblies in the outer row of the } \\
\text { central basket }\end{array}$ & 0.92331 & 0.00091 & 0.93439 \\
\hline $18 \mathrm{rp} .5^{\mathrm{c}}$ & $\begin{array}{l}\text { Mark IA assemblies in the outer row of the } \\
\text { central basket }\end{array}$ & 0.92257 & 0.00084 & 0.93363 \\
\hline $18 \mathrm{rp} .8^{\mathrm{c}}$ & $\begin{array}{l}\text { Mark IA assemblies in the outer row of the } \\
\text { lower basket }\end{array}$ & 0.92000 & 0.00086 & 0.93107 \\
\hline
\end{tabular}


Table 5-1. Calculation Results for Multi-Canister Overpacks Containing Long-Length Mark IA Fuel Assemblies in Mark IV Baskets with a Drained Annulus. (2 sheets)

\begin{tabular}{|c|c|c|c|c|}
\hline Case & MCO configuration & $\mathrm{k}_{\text {calc }}$ & $\sigma_{\mathrm{c}}$ & $\mathrm{k}_{\text {eff }}{ }^{\mathrm{a}}$ \\
\hline $18 \mathrm{rp} .15^{\mathrm{b}}$ & $\begin{array}{c}\text { Mark IA assemblies in the outer row of the } \\
\text { lower basket }\end{array}$ & 0.92059 & 0.00098 & 0.93168 \\
\hline $18 \mathrm{rp} .17^{\mathrm{b}}$ & $\begin{array}{c}\text { Mark IA assemblies in the outer row of the } \\
\text { upper basket }\end{array}$ & 0.92208 & 0.00086 & 0.93315 \\
\hline $18 \mathrm{rp} .13^{\mathrm{c}}$ & $\begin{array}{c}\text { Mark IA assemblies in the outer row of the } \\
\text { upper basket }\end{array}$ & 0.92094 & 0.00079 & 0.93199 \\
\hline
\end{tabular}

${ }^{2} \mathrm{k}_{\text {off }}=\mathrm{k}_{\text {calc }}+0.0004+\left((0.01)^{2}+(1.645)^{2}\left(\sigma_{\mathrm{c}}{ }^{2}+0.002083^{2}\right)\right)^{1 / 2}$ as defined in Section 3.2. This value should be less than 0.95 .

${ }^{b}$ Fuel baskets contain an inner element location in position 4,5.

'Fuel baskets contain an inner element location in position 3,6.

$\mathrm{MCO}=$ multi-canister overpack.

\subsubsection{Design Basis Drop Accidents}

Drop accidents can occur when the MCO is being moved to the transporter in the $\mathrm{K}$ Basins, during transport from the $\mathrm{K}$ Basins to the CVDF or from the CVDF to the CSB, or during handling at the CSB. An MCO drop accident cannot occur at the CVDF because the MCO is not lifted off the transporter, and constraints on the shipping cask prevent tipping (Chenault 1998). Drop accidents during transportation are discussed in HNF-SD-TP-SARP-017 (Edwards 1997). After draining and drying, the MCOs are transported from the CVDF to the CSB for interim storage. The only facility where a flooded MCO could be dropped is the K Basins. Once the MCOs have been dried, criticality cannot occur. The CSB is the only facility containing concrete hard enough to displace the center post in the Mark IA baskets. Receipt of a flooded MCO at CSB and dropping an MCO are two independent events thus making the drop of a flooded MCO with displacement of the center post a beyond design basis event. The result is included for information only.

The most severe hypothetical accident considered is the design basis accident drop of a flooded MCO in which all of the intact fuel within the MCO is broken into rubble. During the transient portion of this accident (during the impact and rebound), the fuel debris may space itself optimally in water.

All the material in the MCOs was modeled as optimal scrap with the scrap in the Mark IA fuel baskets at an enrichment of $1.15 \mathrm{wt} \%{ }^{235} \mathrm{U}$, the weight averaged enrichment of a Mark IA fuel assembly. Both the Mark IA and Mark IV fuel baskets are too small to allow a full load of intact assemblies to become optimally spaced as scrap. Therefore, each fuel basket was modeled containing the mass equal to a partial load of assemblies, 45 Mark IA assemblies or 44 Mark IV assemblies. For the Mark IA MCO, four loading variations were analyzed: the normal two scrap basket case, the case with five fuel baskets and a scrap basket in the bottom tier, the case of five 
fuel baskets and a scrap basket in the top tier, and the case of six fuel baskets. All scrap baskets contained $575 \mathrm{~kg}$ of optimized scrap. Only one loading was analyzed for the Mark IV MCO because there is a single enrichment and, at optimal conditions, the total mass in the MCO is the same regardless of the loading. The safety-class base plates and center post maintain the spacing of the material in the Mark IA MCO. Rearrangement of the material in the MCOs is restricted by the safety-class MCO shell, base, and the filter guard plate on the bottom of the MCO closure plug. The Mark IV basket base plates serve no safety-class function but are essentially identical to the base plates for the Mark IA baskets and are included in the drop models. The results are shown in Table 5-2. Since the MCOs are modeled completely filled with optimum scrap and fuel rubble, no separate analysis was performed for a drop to a horizontal position. Although a drop of a flooded MCO with a displacement of the center post is a beyond design basis event, it was analyzed and the result included in the table. Figures 5-1 and 5-2 show the models used for this analysis.

Table 5-2. Multi-Canister Overpack Drop Analysis for Fuel and Scrap Baskets.

\begin{tabular}{|c|c|c|c|c|}
\hline Case & MCO initial configuration & $k_{\text {calc }}$ & $\sigma_{\mathrm{c}}$ & $k_{\text {effi }}$ \\
\hline mk1ad.1 & $\begin{array}{c}2 \text { scrap baskets and } 4 \text { partially loaded fuel } \\
\text { baskets in a Mark IA MCO }\end{array}$ & 0.89640 & 0.00115 & 0.90754 \\
\hline $\operatorname{mklad} .2$ & $\begin{array}{c}\text { Scrap basket in the bottom tier and } 5 \\
\text { partially loaded fuel baskets in a Mark IA } \\
\text { MCO }\end{array}$ & 0.89783 & 0.00091 & 0.90891 \\
\hline $\operatorname{mklad} .3$ & $\begin{array}{l}\text { Scrap basket in the top tier and } 5 \text { partially } \\
\text { loaded fuel baskets in a Mark IA MCO }\end{array}$ & 0.90480 & 0.00093 & 0.91588 \\
\hline mk1ad.4 & $\begin{array}{l}6 \text { partially loaded fuel baskets in a } \\
\text { Mark IA MCO }\end{array}$ & 0.90572 & 0.00097 & 0.91681 \\
\hline WI & $\begin{array}{l}2 \text { fill scrap baskets and } 4 \text { nibblized fiel } \\
\text { biskets }\end{array}$ & $0.91 \% 86$ & $00007 \%$ & 0.82868 \\
\hline $\mathrm{mk} 1 \mathrm{ad} .8^{\mathrm{b}}$ & $\begin{array}{l}6 \text { partially loaded fuel baskets with the } \\
\text { center post offset by } 2 \text { in. }\end{array}$ & 0.91337 & 0.00086 & 0.92444 \\
\hline $\mathrm{mk} 4 \mathrm{~d} .5$ & $\begin{array}{l}2 \text { scrap baskets and } 3 \text { partially loaded fuel } \\
\text { baskets in a Mark IA MCO }\end{array}$ & 0.92889 & 0.00059 & 0.93991 \\
\hline spr.2 & SPR fuel & 0.87516 & 0.00300 & 0.88723 \\
\hline
\end{tabular}

${ }^{\mathrm{n}} \mathrm{k}_{\mathrm{off}}=\mathrm{k}_{\mathrm{calc}}+0.0004+\left((0.01)^{2}+(1.645)^{2}\left(\mathrm{o}_{\mathrm{c}}^{2}+0.002083^{2}\right)\right)^{1 / 2}$ as defined in Section 3.2. This value should be less than 0.95 .

${ }^{b}$ This case is a beyond design basis accident. $\mathrm{k}_{\text {eff }}$ does not have to be less than 0.95 for this type of event.

$\mathrm{MCO}=$ multi-canister overpack

$\mathrm{SPR}=$ single pass reactor. 
The aluminum-clad SPR fuel has not been observed to have its mechanical integrity degraded by cladding failure and corrosion as is the case with $\mathrm{N}$ Reactor fuel. Therefore, the fuel has been modeled as representative aluminum-clad uranium cylinders with lattice spacing corresponding to optimum moderation. The inside diameters of the scrap baskets containing the SPR fuel have been expanded to the maximum limit of $23.25 \mathrm{in}$. The center post has been offset to its limit of 2 in.

Identified SPR fuel in the K Basins contains either depleted, natural, or $0.95 \mathrm{wt} \%{ }^{235} \mathrm{U}$ enriched uranium. All identified SPR fuel has been modeled with the limiting $0.95 \mathrm{wt} \%{ }^{235} \mathrm{U}$ enrichment. The mass of unidentified SPR fuel has been modeled as a cylinder of $2.1 \mathrm{wt} \%{ }^{235} \mathrm{U}$ enriched uranium around the center post of the tier four basket. This location is the highest importance for this fuel. The result of this calculation, shown as spr. 2 in Table 5-2, is below 0.95 .

The final case is a Mark IA MCO containing completely filled scrap baskets with rubblized fuel baskets. This case bounds all possibilities of the scrap in a partially loaded scrap basket forming an unfavorable geometry in the $\mathrm{MCO}$.

\subsubsection{Loading a Misloaded Basket}

Loading a Mark IV fuel basket with 14 Mark IA fuel assemblies or a Mark IV scrap basket with the mass equivalent to 14 Mark IA fuel assemblies is a contingency because Mark IV and Mark IA fuel are not normally handled concurrently. The only exceptions to this is the longlength Mark IA assemblies in the $\mathrm{K}$ West Basin and the Mark IA material in the K East Basin as discussed in Section 4.5.5 of this report. This section discusses the misloading of a Mark IV basket and loading it into an MCO. Loading Mark IV material into a Mark IA basket is acceptable because of the lower enrichment of the Mark IV fuel.

Several different configurations were analyzed for loading 14 Mark IA fuel assemblies either in the center or in the outer row of a Mark IV fuel basket. For the scrap misload, two configurations were analyzed with the Mark IA fuel around the center pipe of the scrap basket. The mass of the material was $155 \mathrm{~kg}$, equivalent to the mass of $141.25 \mathrm{wt} \%{ }^{235} \mathrm{U}$ outer elements with the rest of the basket filled with $0.95 \mathrm{wt} \%{ }^{235} \mathrm{U}$ scrap. Modeling the scrap this way rather than as a $233 \mathrm{~kg}$ cylinder of $1.15 \mathrm{wt} \%$ scrap gives the highest $\mathrm{k}_{\mathrm{eff}}$. All the scrap was optimized. Table 5-3 lists the results, which show that reactivity stays below 0.95 for every case.

\subsubsection{Misloading a Multi-Canister Overpack}

Contingency cases in which fuel is misloaded in the flooded $\mathrm{MCO}$ and transfer cask are shown in Table 5-4 for both Mark IA and Mark IV MCOs. The cases in Table 5-4 represent situations in which either a scrap basket is loaded adjacent to another scrap basket or the allowed 
limit of two scrap baskets per MCO is exceeded by loading a third scrap basket. For both Mark IA and Mark IV fuel, the reactivity is greatest when the misloaded scrap basket is adjacent to an end scrap basket and a fuel basket is loaded in the top tier. These reactivities are below 0.95 .

Cases for misloaded MCOs in the CSB were not performed using the new basket designs because the results are more conservative using the original analyses. Results listed in Table 5-5 show that the CSB is significantly subcritical even for loading Mark IA fuel and scrap in the Mark IV fuel and scrap baskets in MCOs stored in the CSB, as long as the MCOs are not flooded. The model used for these cases has a 23.0-in. fuel region diameter.

Table 5-3. Basket Misload Analysis for Mark IV Multi-Canister Overpacks.

\begin{tabular}{|c|c|c|c|c|}
\hline Case & MCO configuration & $\mathrm{k}_{\text {calc }}$ & $\sigma_{\mathrm{c}}$ & $\mathrm{k}_{\text {eff }}$ \\
\hline $\mathrm{mk} 4 \mathrm{rl} .1$ & $\begin{array}{c}\text { 14 Mark IA fuel assemblies in the } \\
\text { center of the tier 2 fuel basket }\end{array}$ & 0.91313 & 0.00086 & 0.92420 \\
\hline $\mathrm{mk} 4 \mathrm{rl} .2$ & $\begin{array}{c}\text { 14 Mark IA fuel assemblies in the } \\
\text { center of the tier 3 fuel basket }\end{array}$ & 0.91291 & 0.00087 & 0.92398 \\
\hline $\mathrm{mk} 4 \mathrm{rl} .3$ & $\begin{array}{c}\text { 14 Mark IA fuel assemblies in the } \\
\text { center of the tier 4 fuel basket }\end{array}$ & 0.91120 & 0.00076 & 0.92224 \\
\hline $\mathrm{mk} 4 \mathrm{rl} .4$ & $\begin{array}{c}\text { 14 Mark IA fuel assemblies in the } \\
\text { outer row of the tier 2 fuel basket }\end{array}$ & 0.91357 & 0.00092 & 0.92465 \\
\hline $\mathrm{mk} 4 \mathrm{rl} .5$ & $\begin{array}{c}\text { 14 Mark IA fuel assemblies in the } \\
\text { outer row of the tier 3 fuel basket }\end{array}$ & 0.91227 & 0.00078 & 0.92332 \\
\hline $\mathrm{mk} 4 \mathrm{rl} .6$ & $\begin{array}{c}14 \text { Mark IA fuel assemblies in the } \\
\text { outer row of the tier 4 fuel basket }\end{array}$ & 0.91274 & 0.00098 & 0.92383 \\
\hline $\mathrm{mk} 4 \mathrm{rc} .13$ & $\begin{array}{c}\text { Mass of 14 Mark IA outer elements in } \\
\text { the center of the lower scrap basket }\end{array}$ & 0.91330 & 0.00094 & 0.92438 \\
\hline $\mathrm{mk4rc.14}$ & $\begin{array}{c}\text { Mass of 14 Mark IA outer elements in } \\
\text { the center of the upper scrap basket }\end{array}$ & 0.91485 & 0.00097 & 0.92594 \\
\hline
\end{tabular}

${ }^{*} \mathrm{k}_{\text {eff }}=\mathrm{k}_{\text {ealo }}+0.0004+\left((0.01)^{2}+(1.645)^{2}\left(\sigma_{\mathrm{c}}{ }^{2}+0.002083^{2}\right)\right)^{1 / 2}$ as defined in Section 3.2. This value should be less than 0.95 .

$$
\mathrm{MCO}=\text { multi-canister overpack }
$$


Table 5-4. Misload Analysis for Multi-Canister Overpacks.

\begin{tabular}{|c|c|c|c|c|}
\hline Case & MCO configuration & $\mathrm{k}_{\text {calc }}$ & $\sigma_{\mathrm{c}}$ & $\mathbf{k}_{\text {eff }}^{*}$ \\
\hline mk1rs.1 & $\begin{array}{c}\text { Two scrap baskets in the bottom two } \\
\text { tiers with a fuel basket in the top }\end{array}$ & 0.89278 & 0.00097 & 0.90387 \\
\hline mk1rs.2 & $\begin{array}{c}\text { Two scrap baskets in the bottom two } \\
\text { tiers with a scrap basket in the top }\end{array}$ & 0.89063 & 0.00098 & 0.90172 \\
\hline mk1rs.3 & Scrap baskets in tiers 1, 3, and 6 & 0.88738 & 0.00106 & 0.89849 \\
\hline mk1rs.4 & Scrap baskets in tiers 1, 4, and 6 & 0.88774 & 0.00102 & 0.89884 \\
\hline mk4rs.1 & $\begin{array}{c}\text { Two scrap baskets in the bottom two } \\
\text { tiers with a fuel basket in the top }\end{array}$ & 0.92256 & 0.00082 & 0.93362 \\
\hline mk4rs.2 & $\begin{array}{c}\text { Two scrap baskets in the bottom two } \\
\text { tiers with a scrap basket in the top }\end{array}$ & 0.92040 & 0.00096 & 0.93149 \\
\hline mk4rs.3 & Scrap baskets in tiers 1, 3, and 5 & 0.91265 & 0.00090 & 0.92372 \\
\hline
\end{tabular}

${ }^{*} \mathrm{k}_{\text {off }}=\mathrm{k}_{\text {calc }}+0.0004+\left((0.01)^{2}+(1.645)^{2}\left(\sigma_{\mathrm{c}}{ }^{2}+0.002083^{2}\right)\right)^{1 / 2}$ as defined in Section 3.2. This value should be less than 0.95 .

$\mathrm{MCO}=$ multi-canister overpack 
Table 5-5. Calculated Results for Misloaded Multi-Canister Overpack Stored in the Canister Storage Building. (2 sheets)

\begin{tabular}{|c|c|c|c|c|c|c|c|c|}
\hline & & & ad cluster & & density $\left(\mathrm{g} / \mathrm{cm}^{3}\right)$ & & culation res & \\
\hline Case & MCO type & $\begin{array}{l}\text { Number of } \\
\text { baskets }\end{array}$ & $\begin{array}{l}\text { Assemblies per } \\
\text { basket }\end{array}$ & $\begin{array}{c}\mathrm{MCO} \\
\text { interior }\end{array}$ & $\begin{array}{l}\text { Between storage tubes } \\
\text { and outside MCOs }\end{array}$ & $\mathbf{k}_{\text {calc }}$ & $\begin{array}{l}\text { Standard } \\
\text { deviation }\end{array}$ & $k_{\text {eff }}$ \\
\hline $\mathrm{oc} 3.1 \mathrm{~b}$ & Mark IV & $\begin{array}{l}\text { Top MCO } \\
1 \text { top } \\
3 \text { middle } \\
1 \text { bottom } \\
\text { Bottom MCO } \\
2 \text { top } \\
2 \text { middle } \\
1 \text { bottom }\end{array}$ & $\begin{array}{l}\text { Top MCO } \\
0.95 \text { wt\% Scrap } \\
54 \text { Mark IV } \\
0.95 \text { wt\% Scrap } \\
\\
\text { Bottom MCO } \\
0.95 \text { wt\% Scrap } \\
54 \text { Mark IV } \\
0.95 \text { wt\% Scrap }\end{array}$ & 0.0051 & 0.008 & 0.4134 & 0.0018 & 0.4248 \\
\hline oc3.1 & Mark IV ${ }^{\mathrm{a}}$ & $\begin{array}{l}\text { Top MCO } \\
1 \text { top } \\
3 \text { middle } \\
1 \text { bottom } \\
\text { Bottom MCO } \\
2 \text { top } \\
2 \text { middle } \\
1 \text { bottom }\end{array}$ & $\begin{array}{l}\text { Top MCO } \\
0.95 \text { wt } \% \text { Scrap } \\
54 \text { Mark IV } \\
0.95 \text { wt } \% \text { Scrap } \\
\\
\text { Bottom MCO } \\
0.95 \text { wt } \% \text { Scrap } \\
54 \mathrm{Mark} \text { IV } \\
0.95 \text { wt } \% \text { Scrap }\end{array}$ & 0.0051 & 0.0012 & 0.3939 & 0.0015 & 0.4052 \\
\hline oc3.3b & Mark Iv ${ }^{\Omega}$ & $\begin{array}{l}\text { Top MCO } \\
1 \text { top } \\
3 \text { middle } \\
1 \text { bottom } \\
\text { Bottom MCO } \\
1 \text { top } \\
\\
3 \text { middle } \\
1 \text { bottom }\end{array}$ & $\begin{array}{l}\text { Top MCO } \\
0.95 \text { wt\% scrap } \\
54 \text { Mark IV } \\
0.95 \text { wt } \% \text { scrap } \\
\\
\text { Bottom MCO } \\
0.95 \text { wt\% scrap } \\
\text { mixed with 1 canister } \\
\text { of } 1.25 \text { wt\% scrap } \\
54 \text { Mark IV } \\
0.95 \text { wt\% scrap }\end{array}$ & 0.0051 & 0.008 & 0.4131 & 0.0017 & 0.4244 \\
\hline
\end{tabular}


HNF-SD-SNF-CSER-005 REV 5

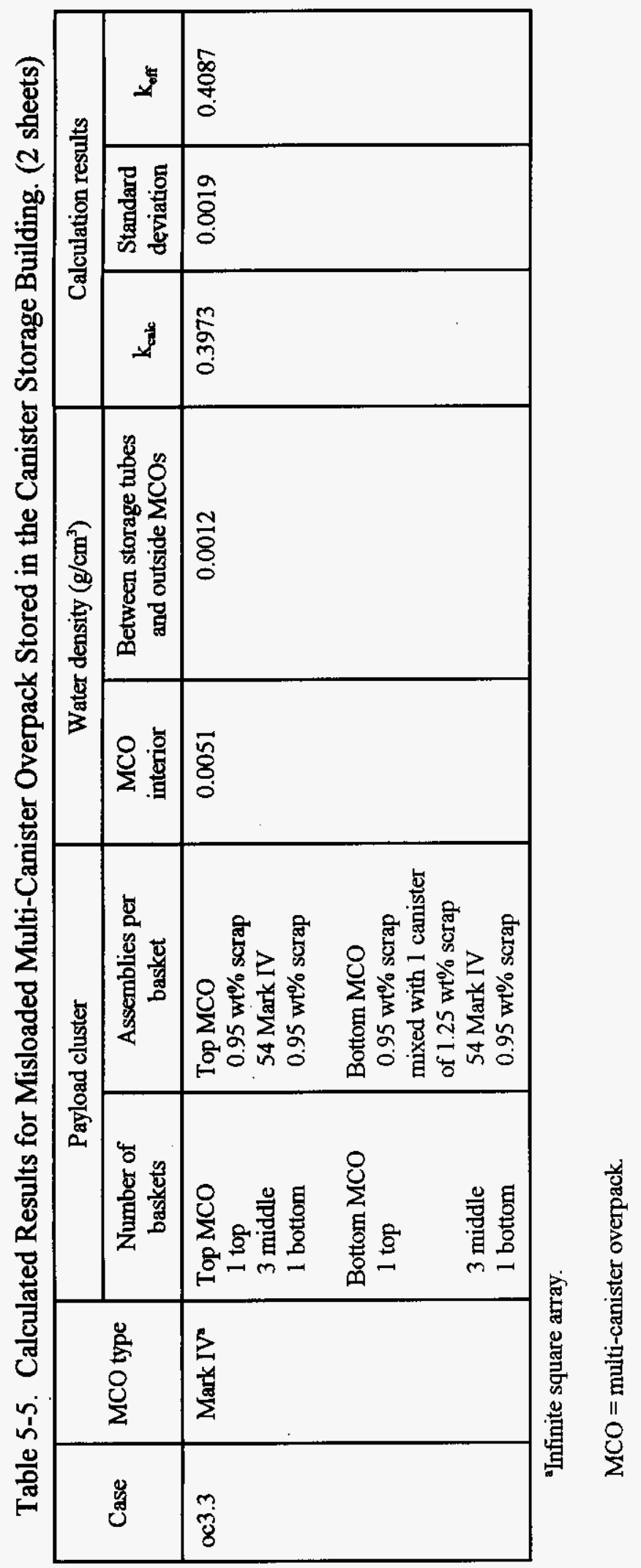


The single contingency case of loading an MCO with one too many scrap baskets of the correctly enriched material has been analyzed. A third scrap basket is modeled next to the top scrap basket in the bottom MCO in a storage tube. This puts three scrap baskets as close to one another as possible in a storage tube for a single contingency. The value of $k_{\text {eff }}$ is 0.4248 for case oc3.1b, which has an intertube optimal water density of $0.008 \mathrm{~g} / \mathrm{cm}^{3}$ (see Table 5-5). The value of $\mathrm{k}_{\mathrm{eff}}$ is lower, 0.4052 for case oc3.1, which has an intertube water density of $0.0012 \mathrm{~g} / \mathrm{cm}^{3}$.

Another contingency is a canister of Mark IA fuel or scrap that has been misplaced and mislabeled as Mark IV in the $\mathrm{K}$ Basins. This one canister is loaded into a Mark IV basket, so a basket intended for $0.95 \mathrm{wt} \%{ }^{235} \mathrm{U}$ enriched scrap is loaded with $233 \mathrm{~kg}$ of $1.25 \mathrm{wt} \%{ }^{235} \mathrm{U}$ enriched scrap, and the rest of the basket is loaded with $0.95 \mathrm{wt} \%{ }^{235} \mathrm{U}$ Mark IV scrap. Scrap baskets are more reactive than intact fuel baskets, so this case bounds cases of a canister of Mark IA fuel in Mark IV fuel baskets. The value for $k_{\text {eff }}$ is 0.4244 , as shown in case oc3.3b, which has an intertube optimal water density of $0.008 \mathrm{~g} / \mathrm{cm}^{3}$ (see Table $5-5$ ). The value of $\mathrm{k}_{\text {eff }}$ is lower, 0.4087 for case $0 c 3.3$, which has an intertube water density of $0.0012 \mathrm{~g} / \mathrm{cm}^{3}$.

These results show that reactivity is well below 0.95 for any single contingency. The conservatisms in the analyses are that all tubes in the array have an extra scrap basket and the array is modeled as an infinite array.

\subsubsection{Flooding a Multi-Canister Overpack at the Canister Storage Building}

The cases presented in Table 4-14 showed that the storage of dry MCOs in the CSB is significantly subcritical. One occurrence that could significantly raise the reactivity to a level of concern is to flood the MCOs. Putting an optimally dense water mist between the tubes could further optimize the system. The CSB design has excluded a sprinkler system and has no other piped-in water. Flooding the MCOs is not considered credible while in storage, but a flooded MCO may be delivered to the CSB. The effect of flooding on reactivity is calculated to show that even this event is within allowable limits. These calculations were not redone using the revised basket designs.

A flooded MCO delivered to the CSB is considered a contingency. Analyses investigating this contingency, summarized in Table 5-6, show that an infinite array of MCOs could be flooded and still be within acceptable limits. The first two cases, oc 2.12 and oc $2.12 \mathrm{~b}$, have water everywhere outside the MCOs at densities of $0.0012 \mathrm{~g} / \mathrm{cm}^{3}$ and $0.008 \mathrm{~g} / \mathrm{cm}^{3}$, respectively. The results for these two cases are values for $\mathrm{k}_{\mathrm{eff}}$ of 0.9236 and 0.9135 . When full density water is put in the storage tubes, as shown in cases oc2.13 and 2.13b in Table 5-6, the values for $\mathrm{k}_{\text {eff }}$ are lower, 0.8902 and 0.8967 . These results show that for MCOs normally loaded with Mark IV intact fuel and scrap, any degree of flooding of the MCOs or storage tubes can be tolerated without exceeding the criticality limit of 0.95 . 
Table 5-6. Calculated Results for Multi-Canister Overpack Internal Flooding at Canister Storage Building.

\begin{tabular}{|c|c|c|c|c|c|c|c|c|}
\hline \multirow[b]{2}{*}{ Case } & \multirow[b]{2}{*}{ MCO type } & \multicolumn{2}{|c|}{ Payload cluster } & \multicolumn{2}{|r|}{ Water density $\left(\mathrm{g} / \mathrm{cm}^{3}\right)$} & \multicolumn{3}{|c|}{ Calculation results } \\
\hline & & $\begin{array}{l}\text { Number of } \\
\text { baskets }\end{array}$ & Assemblies per basket & $\begin{array}{l}\text { MCO } \\
\text { interior }\end{array}$ & $\begin{array}{c}\text { Between storage tubes and } \\
\text { outside MCOs }\end{array}$ & $\mathrm{k}_{\mathrm{calc}}$ & $\begin{array}{l}\text { Standard } \\
\text { deviation }\end{array}$ & $\mathbf{k}_{\text {eff }}$ \\
\hline $\mathrm{oc} 2.12$ & Mark IV" & $\begin{array}{l}1 \text { top } \\
3 \text { middle } \\
1 \text { bottom }\end{array}$ & $\begin{array}{l}0.95 \text { wt\% scrap } \\
54 \text { Mark IV } \\
0.95 \text { wt } \% \text { scrap }\end{array}$ & 1.0 & $\begin{array}{l}0.0012 \text { between storage tubes, } \\
0.0012 \text { outside MCOs }\end{array}$ & 0.9119 & 0.0025 & 0.9236 \\
\hline $\mathrm{oc} 2.12 \mathrm{~b}$ & Mark IV & $\begin{array}{l}1 \text { top } \\
3 \text { middle } \\
1 \text { bottom }\end{array}$ & $\begin{array}{l}0.95 \text { wt\% scrap } \\
54 \text { Mark IV } \\
0.95 \text { wt\% scrap }\end{array}$ & 1.0 & $\begin{array}{l}0.008 \text { between storage tubes, } \\
0.008 \text { outside MCOs }\end{array}$ & 0.9016 & 0.0027 & 0.9135 \\
\hline $\mathrm{oc} 2.12 \mathrm{c}$ & Mark IV & $\begin{array}{l}1 \text { top } \\
3 \text { middle } \\
1 \text { bottom }\end{array}$ & $\begin{array}{l}0.95 \text { wt\% scrap } \\
54 \text { Mark IV } \\
0.95 \text { wt\% scrap }\end{array}$ & 1.0 & $\begin{array}{l}0.008 \text { between storage tubes, } \\
0.008 \text { outside MCOs }\end{array}$ & 0.9027 & 0.0022 & 0.9143 \\
\hline$\circ 2.13$ & Mark IV & $\begin{array}{l}1 \text { top } \\
3 \text { middle } \\
1 \text { bottom }\end{array}$ & $\begin{array}{l}0.95 \text { wt } \% \text { scrap } \\
54 \text { Mark IV } \\
0.95 \text { wt } \% \text { scrap }\end{array}$ & 1.0 & $\begin{array}{l}0.0012 \text { between storage tubes, } \\
1.0 \text { outside MCOs }\end{array}$ & 0.8782 & 0.0029 & 0.8902 \\
\hline oc2.13b & Mark IV & $\begin{array}{l}1 \text { top } \\
3 \text { middle } \\
1 \text { bottom }\end{array}$ & $\begin{array}{l}0.95 \text { wt\% scrap } \\
54 \text { Mark IV } \\
0.95 \text { wt\% scrap }\end{array}$ & 1.0 & $\begin{array}{l}0.008 \text { between storage tubes, } \\
1.0 \text { outside MCOs }\end{array}$ & 0.8849 & 0.0026 & 0.8967 \\
\hline oc2.13c & Mark IV & $\begin{array}{l}1 \text { top } \\
3 \text { middle } \\
1 \text { bottom }\end{array}$ & $\begin{array}{l}0.95 \text { wt } \% \text { scrap } \\
54 \text { Mark IV } \\
0.95 \text { wt } \% \text { scrap }\end{array}$ & 1.0 & $\begin{array}{l}0.008 \text { between storage tubes, } \\
1.0 \text { outside MCOs }\end{array}$ & 0.8859 & 0.0024 & 0.8976 \\
\hline $\operatorname{oc} 1.15 \mathrm{c}$ & Mark $\mathrm{IA}^{\mathrm{c}}$ & $\begin{array}{l}1 \text { top } \\
4 \text { middle } \\
1 \text { bottom }\end{array}$ & $\begin{array}{l}1.25 \text { wt\% scrap } \\
48 \text { Mark IA } \\
1.25 \text { wt } \% \text { scrap }\end{array}$ & 1.0 & $\begin{array}{l}0.008 \text { between storage tubes } \\
\text { and outside MCOs }\end{array}$ & 0.8940 & 0.0009 & 0.9051 \\
\hline ocl.16c & Mark IV & $\begin{array}{l}1 \text { top } \\
3 \text { middle } \\
1 \text { bottom }\end{array}$ & $\begin{array}{l}0.95 \text { wt\% scrap } \\
54 \text { Mark IV } \\
0.95 \text { wt\% scrap }\end{array}$ & 1.0 & $\begin{array}{l}0.008 \text { between storage tubes } \\
\text { and outside MCOs }\end{array}$ & 0.8875 & 0.0014 & 0.8987 \\
\hline
\end{tabular}

Infinite square array.

'Infinite hexagonal array.

Model of actual 10 by 22 by 2 hexagonal array of MCOs in CSB storage tubes with concrete walls, floor, and operating deck.

$\mathrm{MCO}=$ multi-canister overpack 


\section{HNF-SD-SNF-CSER-005 REV 5}

\subsubsection{Flooding a Canister Storage Building Storage Tube}

Flooding a storage tube is considered a contingency. The floor plugs are vented, but water lines are excluded from the vault operating floor and area. Only a very unusual occurrence would bring water onto the operating floor and into the storage tubes. Flooding the 1.5-in. radial gap between the $\mathrm{MCO}$ and the storage tube has no significant effect on the reactivity of dry MCOs in the CSB storage tubes. Comparing cases oc1.3 and oc $1.3 \mathrm{~b}$ in Table 5-7 with oc2.11 and oc2.11b (for full density water in the gap) in Table 5-7, shows all values for $k_{\text {eff }}$ are between 0.40 and 0.43 . Each pair of cases uses $0.0012 \mathrm{~g} / \mathrm{cm}^{3}$ and $0.008 \mathrm{~g} / \mathrm{cm}^{3}$ of water in the intertube space. Case oc $2.14 \mathrm{~b}$ in Table $5-7$ for $0.008 \mathrm{~g} / \mathrm{cm}^{3}$ intertube water density with the gap filled with half density water was also in the 0.40 to 0.43 range for $\mathrm{k}_{\text {eff }}$. These cases evaluated an MCO loaded with Mark IV fuel. An MCO loaded with Mark IA fuel is evaluated in cases oc2.10a and oc2.10ba in Table 5-7 with full density water in the gap, and the values for $\mathrm{k}_{\text {eff }}$ are less, 0.4138 and 0.4125 , respectively. These results indicate that for dry MCOs, flooding storage tubes is not a criticality concern. These cases were not reperformed using the revised basket designs.

\subsubsection{Flooding at the Canister Storage Building Storage Array}

The lack of water lines in the CSB and the fact that the only access to the vault space between the storage tubes is through the two stacks that allow natural convection circulation for cooling precludes flooding of the vault space between the tubes. However, to show the conservative nature of the CSB, the contingency of flooding the vault has been analyzed using the infinite array model. Progressively filling the vault to a quarter full (the bottom MCO is half submerged), and to half full (the bottom MCO is completely submerged), lowers the value of $\mathrm{k}_{\text {eff }}$ to 0.3877 and 0.3823 , as shown for cases oc2.1 and oc2.2, respectively, in Table 5-8. Case oc2.8 in Table 5-8 has an even lower value of 0.3463 for the vault fully flooded (both MCOs submerged). The greater the flooding of the vault, the greater the neutronic isolation of each storage tube. The progressive flooding of a vault decreases the overall reactivity of the array.

The effect of water moderation between the storage tubes also was investigated. An infinite horizontal array model of CSB storage tubes containing two normally loaded MCOs was analyzed with water densities from 0.0005 to $1.0 \mathrm{~g} / \mathrm{cm}^{3}$ between the tubes. Figure 5-3 shows a plot of the data for flooded MCOs, and Figure 5-4 shows a plot of the data for dry MCOs. The peak in reactivity occurs at $0.008 \mathrm{~g} / \mathrm{cm}^{3}$ water density between the storage tubes for dry MCOs.

Case ocsb05 in Table 5-8 gives the results of the 10 by 22 by 2 hexagonal array model of normally loaded Mark IV fuel in the MCOs with $0.008 \mathrm{~g} / \mathrm{cm}^{3}$ intertube moisture. The value of $\mathrm{k}_{\text {eff }}$ was 0.3985 . Thus, the actual reactivity for the dry MCO in the CSB storage tube is highly subcritical. 
Table 5-7. Calculation Results for Canister Storage Building Storage Tube Flooding.

\begin{tabular}{|c|c|c|c|c|c|c|c|c|}
\hline \multirow[b]{2}{*}{ Case } & \multirow[b]{2}{*}{ MCO type } & \multicolumn{2}{|c|}{ Payload cluster } & \multicolumn{2}{|c|}{ Water density $\left(\mathrm{g} / \mathrm{cm}^{3}\right)$} & \multicolumn{3}{|c|}{ Calculation results } \\
\hline & & No. of baskets & Assemblies per basket & $\begin{array}{l}\text { MCO } \\
\text { interior }\end{array}$ & $\begin{array}{l}\text { Between storage tubes } \\
\text { and outside MCOs }\end{array}$ & $\mathbf{k}_{\text {ealc }}$ & $\begin{array}{l}\text { Standard } \\
\text { deviation }\end{array}$ & $\mathbf{k}_{\text {eff }}$ \\
\hline oc1.3b & Mark IV & $\begin{array}{l}1 \text { top } \\
3 \text { middle } \\
1 \text { bottom }\end{array}$ & $\begin{array}{l}0.95 \text { wt\% scrap } \\
54 \text { Mark IV } \\
0.95 \text { wt\% scrap }\end{array}$ & 0.0051 & 0.008 (vapor) & 0.4114 & 0.0020 & 0.4229 \\
\hline $0 \mathrm{c} 1.3 \mathrm{c}$ & Mark IV' & $\begin{array}{l}1 \text { top } \\
3 \text { middle } \\
1 \text { bottom }\end{array}$ & $\begin{array}{l}0.95 \text { wt } \% \text { scrap } \\
54 \text { Mark IV } \\
0.95 \text { wt } \% \text { scrap }\end{array}$ & 0.0051 & 0.008 (vapor) & 0.4105 & 0.0020 & 0.4220 \\
\hline$\propto 2.11$ & Mark IV & $\begin{array}{l}1 \text { top } \\
3 \text { middle } \\
1 \text { bottom }\end{array}$ & $\begin{array}{l}0.95 \text { wt } \% \text { scrap } \\
54 \text { Mark IV } \\
0.95 \text { wt } \% \text { scrap }\end{array}$ & 0.0051 & $\begin{array}{l}0.0012 \text { (vapor) between } \\
\text { storage tubes } \\
1.0 \text { outside MCOs }\end{array}$ & 0.4069 & 0.0018 & 0.4183 \\
\hline $\mathrm{oc} 2.11 \mathrm{~b}$ & Mark $I V^{2}$ & $\begin{array}{l}1 \text { top } \\
3 \text { middle } \\
1 \text { bottom }\end{array}$ & $\begin{array}{l}0.95 \text { wt } \% \text { scrap } \\
54 \text { Mark V } \\
0.95 \text { wt } \% \text { scrap }\end{array}$ & 0.0051 & $\begin{array}{l}0.008 \text { (vapor) between } \\
\text { storage tubes } \\
1.0 \text { outside MCOs }\end{array}$ & 0.4042 & 0.0026 & 0.4160 \\
\hline oc2.11c & Mark IV & $\begin{array}{l}1 \text { top } \\
3 \text { middle } \\
1 \text { bottom }\end{array}$ & $\begin{array}{l}0.95 \text { wt\% scrap } \\
54 \text { Mark IV } \\
0.95 \text { wt\% scrap }\end{array}$ & 0.0051 & $\begin{array}{l}0.008 \text { (vapor) between } \\
\text { storage tubes } \\
1.0 \text { outside } \mathrm{MCOs}\end{array}$ & 0.4024 & 0.0023 & 0.4140 \\
\hline oc2.14b & Mark IV & $\begin{array}{l}1 \text { top } \\
3 \text { middle } \\
1 \text { bottom }\end{array}$ & $\begin{array}{l}0.95 \text { wt } \% \text { scrap } \\
54 \text { Mark IV } \\
0.95 \text { wt } \% \text { scrap }\end{array}$ & 0.0051 & $\begin{array}{l}0.008 \text { (vapor) between } \\
\text { storage tubes } \\
0.5 \text { outside MCOs }\end{array}$ & 0.4109 & 0.0020 & 0.4224 \\
\hline $\mathrm{oc} 2.10 \mathrm{a}$ & Mark $\mathrm{IA}^{2}$ & $\begin{array}{l}1 \text { top } \\
4 \text { middle } \\
1 \text { bottom }\end{array}$ & $\begin{array}{l}1.25 \mathrm{wt} \% \text { scrap } \\
48 \mathrm{Mark} \text { IV } \\
1.25 \mathrm{wt} \% \text { scrap }\end{array}$ & 0.0051 & $\begin{array}{l}0.0012 \text { (vapor) between } \\
\text { storage tubes } \\
0.5 \text { outside MCOs }\end{array}$ & 0,4021 & 0.0024 & 0.4138 \\
\hline $\mathrm{oc} 2.10 \mathrm{ba}$ & Mark IA & $\begin{array}{l}1 \text { top } \\
4 \text { middle } \\
1 \text { bottom }\end{array}$ & $\begin{array}{l}1.25 \text { wt } \% \text { scrap } \\
48 \text { Mark IV } \\
1.25 \text { wt } \% \text { scrap }\end{array}$ & 0.0051 & $\begin{array}{l}0.008 \text { (vapor) between } \\
\text { storage tubes } \\
0.5 \text { outside } \mathrm{MCOs}\end{array}$ & 0.4008 & 0.0024 & 0.4125 \\
\hline
\end{tabular}

Infinite square array.

Infinite hexagonal array.

$\mathrm{MCO}=$ multi-canister overpack. 
Table 5-8. Calculation Results for Canister Storage Building Vault Flooding.

\begin{tabular}{|c|c|c|c|c|c|c|c|c|}
\hline \multirow[b]{2}{*}{ Case } & \multirow[b]{2}{*}{ MCO type } & \multicolumn{2}{|c|}{ Payload cluster } & \multicolumn{2}{|c|}{ Water density $\left(\mathrm{g} / \mathrm{cm}^{3}\right)$} & \multicolumn{3}{|c|}{ Calculation results } \\
\hline & & $\begin{array}{l}\text { Number of } \\
\text { baskets }\end{array}$ & Assemblies per basket & $\begin{array}{l}\text { MCO } \\
\text { interior }\end{array}$ & $\begin{array}{l}\text { Between storage tubes } \\
\text { and outside MCOs }\end{array}$ & $\mathbf{k}_{\text {calc }}$ & $\begin{array}{l}\text { Standard } \\
\text { deviation }\end{array}$ & $\mathbf{k}_{\text {eff }}$ \\
\hline oc2.1 & Mark IV & $\begin{array}{l}1 \text { top } \\
3 \text { middle } \\
1 \text { bottom }\end{array}$ & $\begin{array}{l}0.95 \text { wt\% scrap } \\
54 \text { Mark IV } \\
0.95 \text { wt\% scrap }\end{array}$ & 0.0051 & $\begin{array}{l}1.00 \text { (vault flooded to } \\
\text { one-quarter height) }\end{array}$ & 0.3764 & 0.0016 & 0.3877 \\
\hline $\mathrm{oc} 2.1 \mathrm{c}$ & Mark IV & $\begin{array}{l}1 \text { top } \\
3 \text { middle } \\
1 \text { bottom }\end{array}$ & $\begin{array}{l}0.95 w t \% \text { scrap } \\
54 \text { Mark IV } \\
0.95 w t \% \text { scrap }\end{array}$ & 0.0051 & $\begin{array}{l}1.00 \text { (vault flooded to } \\
\text { one-quarter height, } \\
0.008 \text { outside MCOs) }\end{array}$ & 0.3923 & 0.0020 & 0.4038 \\
\hline$\circ 2.2$ & Mark IV & $\begin{array}{l}1 \text { top } \\
3 \text { middle } \\
1 \text { bottom }\end{array}$ & $\begin{array}{l}0.95 \text { wt } \% \text { scrap } \\
54 \text { Mark IV } \\
0.95 \text { wt } \% \text { scrap }\end{array}$ & 0.0051 & $\begin{array}{l}1.00 \text { (vault flooded to } \\
\text { half height) }\end{array}$ & 0.3711 & 0.0014 & 0.3823 \\
\hline $\mathrm{oc} 2.2 \mathrm{c}$ & Mark IV & $\begin{array}{l}1 \text { top } \\
3 \text { middle } \\
1 \text { bottom }\end{array}$ & $\begin{array}{l}0.95 \text { wt } \% \text { scrap } \\
54 \text { Mark IV } \\
0.95 \text { wt } \% \text { scrap }\end{array}$ & 0.0051 & $\begin{array}{l}1.00 \text { (vault flooded to } \\
\text { half height, } 0.008 \\
\text { outside MCOs) }\end{array}$ & 0.3808 & 0.0020 & 0.3923 \\
\hline oc2.8 & Mark IV & $\begin{array}{l}1 \text { top } \\
3 \text { middle } \\
1 \text { bottom }\end{array}$ & $\begin{array}{l}0.95 \text { wt } \% \text { scrap } \\
54 \text { Mark IV } \\
0.95 \text { wt } \% \text { scrap }\end{array}$ & 0.0051 & $\begin{array}{l}1.00 \text { (vault flooded to } \\
\text { full height) }\end{array}$ & 0.3348 & 0.0020 & 0.3463 \\
\hline $\mathrm{oc} 2.8 \mathrm{c}$ & Mark IV & $\begin{array}{l}1 \text { top } \\
3 \text { middle } \\
1 \text { bottom }\end{array}$ & $\begin{array}{l}0.95 \text { wt\% scrap } \\
54 \text { Mark IV } \\
0.95 \text { wt } \% \text { scrap }\end{array}$ & 0.0051 & $\begin{array}{l}1.00 \text { (vault flooded to } \\
\text { full height, } 0.008 \\
\text { outside MCOs) }\end{array}$ & 0.3349 & 0.0016 & 0.3462 \\
\hline ocsb05 & Mark IV & $\begin{array}{l}1 \text { top } \\
3 \text { middle } \\
1 \text { bottom }\end{array}$ & $\begin{array}{l}0.95 \text { wt } \% \text { scrap } \\
54 \text { Mark IV } \\
0.95 \text { wt } \% \text { scrap }\end{array}$ & 0.0051 & 0.008 (vapor) & 0.3874 & 0.0008 & 0.3985 \\
\hline
\end{tabular}

Infinite square array.

'Infinite hexagonal array.

"Modeled using 10 by 22 by 2 array of MCOs in CSB storage tubes with concrete walls, floors, and walls. Fuel density corresponds to the actual 10 by 22 by 2 hexagonal array of CSB.

$\mathrm{CSB}=$ Canister Storage Building $\mathrm{MCO}=$ multi-canister overpack . 
Figure 5-4 shows that for water densities greater than $0.008 \mathrm{~g} / \mathrm{cm}^{3}$ in the vault, the reactivity drops to that for a single fully water-reflected $\mathrm{MCO}$. Results presented in this section also show that for flooding of the vault space, the reactivity is always below 0.42 . For this degree of subcriticality, even at optimum intertube water density, no restriction on fire fighting is necessary for criticality control. For CSB calculations, this water content $\left(0.008 \mathrm{~g} / \mathrm{cm}^{3}\right)$ is used as a conservative assumption in calculations. Figure 5-4 shows that at the lower water densities of normal operations, the reactivity of the storage vault will be lower by about 0.02 . These calculations were not reperformed using the revised basket designs nor were similar analyses performed for Mark IA MCOs.

Figure 5-3 shows the $\mathrm{k}_{\text {eff }}$ for a range of water densities between the CSB storage tubes when they are loaded with flooded MCOs containing Mark IV fuel. The curve rises only marginally, to a maximum $\mathrm{k}_{\text {eff }}$ less than 0.93 at a water density of $0.002 \mathrm{~g} / \mathrm{cm}^{3}$. This shows the reactivity for an infinite array of fully flooded Mark IV MCOs in the CSB will be below 0.95 for all values of interspersed moderation between the storage tubes. Flooding the CSB vault containing flooded MCOs is a beyond design basis event. Reactivity is not required to stay below 0.95 for an event such as this, and the information is provided for information only.

\subsubsection{Handling a Flooded Multi-Canister Overpack with the Multi-Canister Overpack Handling Machine}

Should a flooded MCO get to the CSB, it could be loaded into a storage tube. Figure 5-5 shows the configuration of the MCO being lowered by the MHM, and Table 5-9 shows that the reactivity is acceptable for this single contingency event.

\subsubsection{Loading a Multi-Canister Overpack in a Tube with no Intermediate Impact Absorber}

It is possible to load the second $\mathrm{MCO}$ in a storage tube without installing the intermediate impact absorber. For this situation, the CSB array was modeled containing one tube with two MCOs and no intermediate impact absorber. The model used for these calculations was updated to include the lower and intermediate impact absorber, the latest basket and MCO dimensions, correct mass limits for the scrap baskets, and the full length of the MCO. Both the normal array of drained MCOs and the array containing the tube with no impact absorber were analyzed and the results reported in Table 5-10. The results show that the presence of the intermediate impact absorber has no effect on reactivity for drained MCOs. This is because of the space and plug above the top scrap basket, which isolates the top and bottom MCOs from each other. 
Table 5-9. Flooded Multi-Canister Overpacks in the Multi-Canister Overpack Handling Machine and Lowered through the Canister Storage Building Floor.

\begin{tabular}{|c|c|c|c|c|}
\hline Case & MCO initial configuration & $\mathrm{k}_{\text {calc }}$ & $\sigma_{\mathrm{c}}$ & $\mathrm{k}_{\text {eff }}{ }^{*}$ \\
\hline $\mathrm{mhm} 1.0$ & Flooded Mark IA MCO in the MHM & 0.89770 & 0.00101 & 0.90880 \\
\hline $\mathrm{mhm} 1.2$ & $\begin{array}{c}\text { Flooded Mark IA MCO lowered } \\
2.5 \mathrm{ft} \text { through the floor }\end{array}$ & 0.89562 & 0.00093 & 0.90670 \\
\hline $\mathrm{mhm} 1.5$ & $\begin{array}{c}\text { Flooded Mark IA MCO lowered 5 ft } \\
\text { through the floor }\end{array}$ & 0.89726 & 0.00096 & 0.90835 \\
\hline $\mathrm{mhm} 4.1$ & Flooded Mark IV MCO in the MHM & 0.92192 & 0.00086 & 0.93299 \\
\hline $\mathrm{mhm} 4.3$ & $\begin{array}{c}\text { Flooded Mark IV MCO lowered 2.5 ft } \\
\text { through the floor }\end{array}$ & 0.92048 & 0.00090 & 0.93155 \\
\hline $\mathrm{mhm} 4.5$ & $\begin{array}{c}\text { Flooded Mark IV MCO lowered 5 ft } \\
\text { through the floor }\end{array}$ & 0.91996 & 0.00089 & 0.93103 \\
\hline
\end{tabular}

${ }^{*} \mathrm{k}_{\text {off }}=\mathrm{k}_{\text {ealc }}+0.0004+\left((0.01)^{2}+(1.645)^{2}\left(\sigma_{\mathrm{c}}{ }^{2}+0.002083^{2}\right)\right)^{1 / 2}$ as defined in Section 3.2. This value should be less than 0.95 .

$\mathrm{MCO}=$ multi-canister overpack

$\mathrm{MHM}=$ multi-canister overpack handling machine.

Table 5-10. Canister Storage Building Array with Single Storage Tube Containing Two Multi-Canister Overpacks and No Intermediate Impact Absorber.

\begin{tabular}{|c|c|c|c|c|}
\hline Case & MCO initial configuration & $\mathrm{k}_{\text {calc }}$ & $\sigma_{\mathrm{c}}$ & $\mathrm{k}_{\text {off }}$ \\
\hline $\mathrm{csb} 1.0$ & $10 \times 22 \times 2$ array of dry Mark IA MCOs & 0.32167 & 0.00029 & 0.33265 \\
\hline $\mathrm{csb} 1.1$ & $\begin{array}{c}10 \times 22 \times 2 \text { array of dry Mark IA MCOs; one } \\
\text { tube contains no intermediate impact absorber }\end{array}$ & 0.32170 & 0.00028 & 0.33268 \\
\hline csb4.0 & $10 \times 22 \times 2$ array of dry Mark IV MCOs & 0.34860 & 0.00034 & 0.35959 \\
\hline csb4.1 & $\begin{array}{c}10 \times 22 \times 2 \text { array of dry Mark IV MCOs; one } \\
\text { tube contains no intermediate impact absorber }\end{array}$ & 0.34878 & 0.00033 & 0.35976 \\
\hline
\end{tabular}
less than 0.95 .

${ }^{*} \mathrm{k}_{\text {off }}=\mathrm{k}_{\text {calc }}+0.0004+\left((0.01)^{2}+(1.645)^{2}\left(\mathrm{o}_{\mathrm{c}}{ }^{2}+0.002083^{2}\right)\right)^{1 / 2}$ as defined in Section 3.2. This value should be $\mathrm{MCO}=$ multi-canister overpack 


\subsubsection{Flooding the Sampling/Weld Station with Glycol}

The temperature of an MCO in the CSB sampling/weld station is controlled by a cooling system containing propylene glycol. The glycol circulates through the upper shield region that surrounds the upper portion of the MCO. For this scenario, it was assumed that the cooling system failed and the void region along the entire lengths of the MCO was flooded. The composition of the coolant was assumed to be $100 \%$ propylene glycol $\left(\mathrm{C}_{3} \mathrm{H}_{8} \mathrm{O}_{2}\right)$. More than 12 in. of concrete separates the stations from each other, neutronically isolating them, so only one station is modeled. The personnel access area around the top of the MCO was assumed to be concrete to provide maximum reflection. Calculations were performed for both flooded and drained MCOs and the results are listed in Table 5-11.

Table 5-11. Canister Storage Building Sampling/Weld Station Flooded with Propylene Glycol and Containing a Multi-Canister Overpack.

\begin{tabular}{|l|l|c|c|c|}
\hline \multirow{2}{*}{ Case } & \multirow{2}{*}{ Description } & \multicolumn{3}{c|}{ Calculation results } \\
\cline { 3 - 5 } & & $\mathrm{k}_{\text {calc }}$ & $\sigma_{\mathrm{c}}$ & $\mathrm{k}_{\text {off }}$ \\
\hline gly1.0 & Mark IA MCO drained & 0.27052 & 0.00054 & 0.28153 \\
\hline glyl.1 & Mark IA MCO flooded & 0.88571 & 0.00097 & 0.89680 \\
\hline gly4.0 & Mark IV MCO drained & 0.30981 & 0.00073 & 0.32085 \\
\hline gly4.1 & Mark IV MCO flooded & 0.91360 & 0.00094 & 0.92468 \\
\hline
\end{tabular}

${ }^{*} \mathrm{k}_{\text {eff }}=\mathrm{k}_{\text {calc }}+0.0004+\left((0.01)^{2}+(1.645)^{2}\left(\sigma_{\mathrm{c}}{ }^{2}+0.002083^{2}\right)\right)^{1 / 2}$ as defined in Section 3.2. This value should be less than 0.95 .

$\mathrm{MCO}=$ multi-canister overpack

These results show that the cooling system containing propylene glycol for the sampling/weld station does not compromise criticality safety. The models of the MCO were updated to incorporate the most recent design changes to the MCO internals and the fuel and scrap baskets.

\subsection{CRITICALITY INSTRUMENTATION}

This section addresses the need for criticality alarm systems and criticality detection systems. DOE Order 5480.24 references ANSI/ANS-8.3-1997, Criticality Accident Alarm System, for requirements relating to nuclear criticality alarm systems. ANSI/ANS-8.3-1997states that neither a criticality alarm system or criticality detection system is required where the probability of a criticality accident is determined to be less than $1 \times 10^{-6}$ per year. Interpretive guidance on the probability determination (Holten 1993) states: "The use of $10^{-6}$ does not necessarily mean that a PRA [probabilistic risk assessment] has to be performed. Reasonable grounds shall be presented 
on the basis of commonly accepted engineering judgement." Accordingly, the remaining discussion supports the judgement that no criticality alarm or detection systems are required in the CVDF or the CSB.

The MCO is designed to be criticality safe even when fully moderated by water, as it normally is until it is drained at the CVDF. Only one MCO is allowed per process bay at the CVDF. Under normal conditions at the CSB, the MCOs will be dry, and without moderation, the SNF stored at the CSB cannot be made critical. The presence of a significant quantity of water or other neutron moderator in or around the MCOs at the CSB is judged to be an unlikely event. Furthermore, all situations analyzed show that $k_{\text {eff }}$ is less than the criticality safety limit of 0.95 .

These results show that for single MCOs, at least three contingencies (unlikely, independent, and concurrent events) are necessary before $\mathrm{k}_{\text {eff }}$ exceeds 0.95 . An event is classified as unlikely if its expected frequency is greater than $10^{-4}$ per year but less than $10^{-2}$ per year (DOE-STD-3009-94). The probability of three contingencies is then less than $\left(10^{-2}\right)^{3}$ per year or $10^{-6}$ per year. Thus, on the CSB operating deck, where MCOs are handled as single units, the probability of a criticality is less than $10^{-6}$ per year.

The following discussion provides an analysis of the CSB vault. From results reported earlier in this document, the most reactive single-contingency $\mathrm{MCO}$ at the $\mathrm{K}$ Basins contains completely rubblized Mark IV fuel. This MCO is also flooded, which is the normal condition there. At the CSB, where MCOs are normally dry, a flooded and rubblized MCO requires two contingencies. Analysis described in Section 5.7.2 shows that the addition of a significant quantity of water to the vault and storage tubes decreases reactivity.

Another two-contingency case unique to the CSB vault involves a scenario in which a normal (drained) MCO is placed in a storage tube on top of a flooded MCO with no intermediate impact absorber between the two. Calculations described in Section 5.2.9 show that the intermediate impact absorber has an insignificant effect on reactivity. Thus, the $\mathrm{k}_{\text {eff }}$ of an arrangement in which a flooded MCO has a normal MCO directly above or below it would be similar to that of a flooded MCO in a storage tube (see Section 5.2.3).

Thus, any two credible contingencies in the CSB vault will not result in a criticality. A third contingency is required. As with a single $\mathrm{MCO}$ on the operating deck, the probability of a criticality in the vault is then judged to be less than $10^{-6}$ per year. Therefore no criticality alarm system or criticality detection system is required at the CVDF or CSB.

\subsection{SUMMARY}

In summary, conservative assumptions have been made for determining worst-case normal and off-normal conditions for the MCO during processing at the CVDF and storage at the CSB. The analyses assumed unirradiated fuel, optimum size scrap rod diameters and optimum water to fuel volume ratios for the scrap and rubble, and appropriate contingencies of misloading scrap or fuel in an MCO. Many of the analyses performed for this CSER have been redone using the 


\section{HNF-SD-SNF-CSER-005 REV 5}

revised designs of the $\mathrm{MCO}$ and baskets and incorporate the limits on mass in the scrap baskets established by HNF-SD-SNF-CSER-010 (Kessler and Peck 1999). Some analyses were not redone using revised designs, specifically ones pertaining to drained MCOs in the CSB vault because they were conservative in their assumptions. The results are retained in this revision.

The analyses show that the double contingency principle is met. In many cases, the off-normal conditions have gone beyond the double contingency criteria. Scenarios involving misloading an MCO and shipping a flooded MCO from the CVDF to the CSB require the failure of several administrative controls to occur. Flooding of MCOs in storage at the CSB not only requires failure of administrative controls but also failure of CSB design features. In spite of these assumptions, the scenarios are in compliance with the criticality safety requirements.

In conclusion, the possibility that the $\mathrm{k}_{\mathrm{eff}}$ of an $\mathrm{MCO}$ or of an array of MCOs could exceed 0.95 requires not only the failure of design features and the failure of administrative controls but also requires that the fissile material form unfavorable configurations that are not credible. This is especially true for the scrap, which is assumed to be optimized for all calculations. The $\mathrm{k}_{\mathrm{eff}}$ for credible scenarios will be considerably less than 0.95 . 
HNF-SD-SNF-CSER-005 REV 5

Figure 5-1. Drop Analysis Input Model - Mark IA.

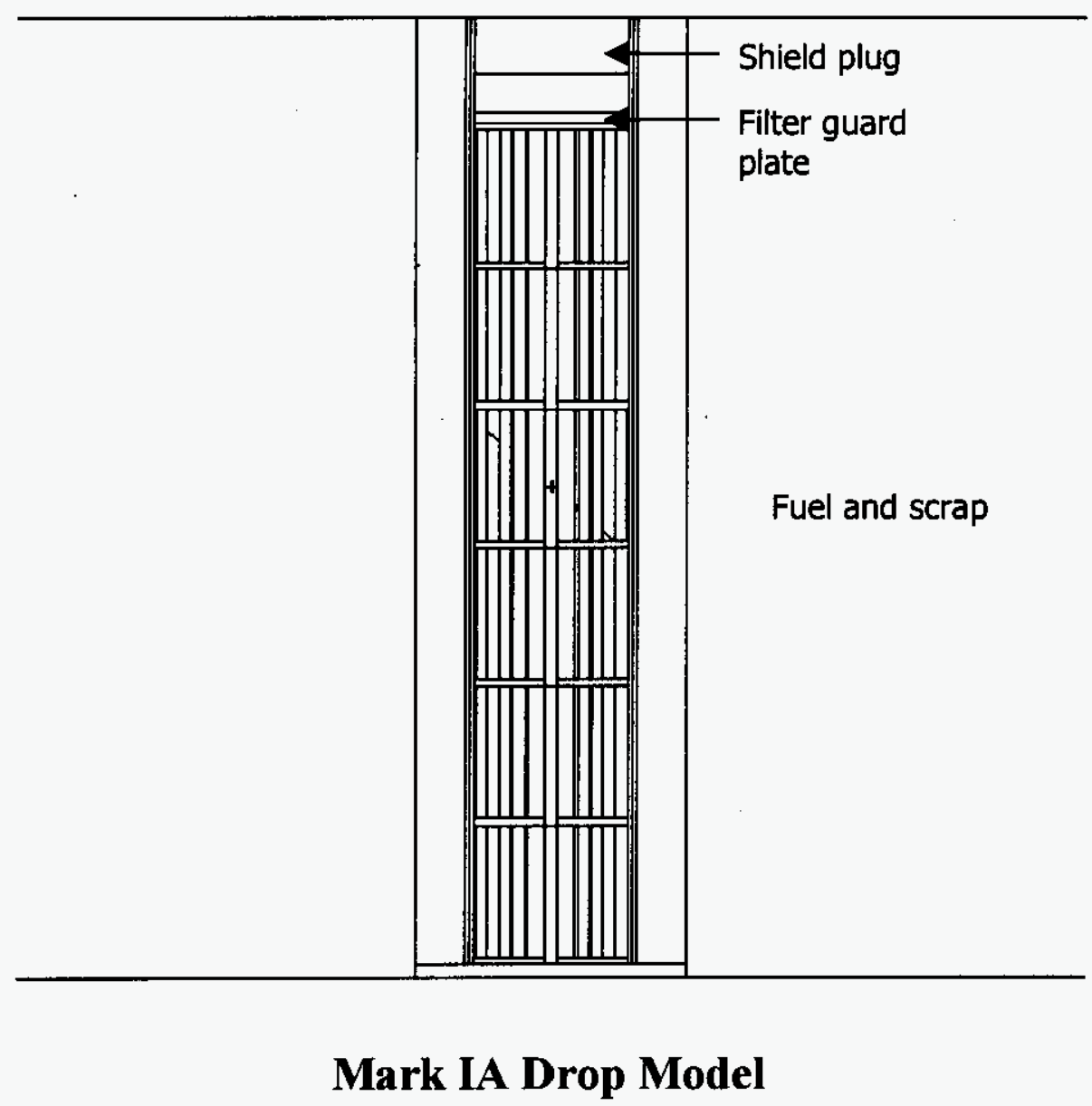




\section{HNF-SD-SNF-CSER-005 REV 5}

Figure 5-2. Drop Analysis Input Model - Mark IV.

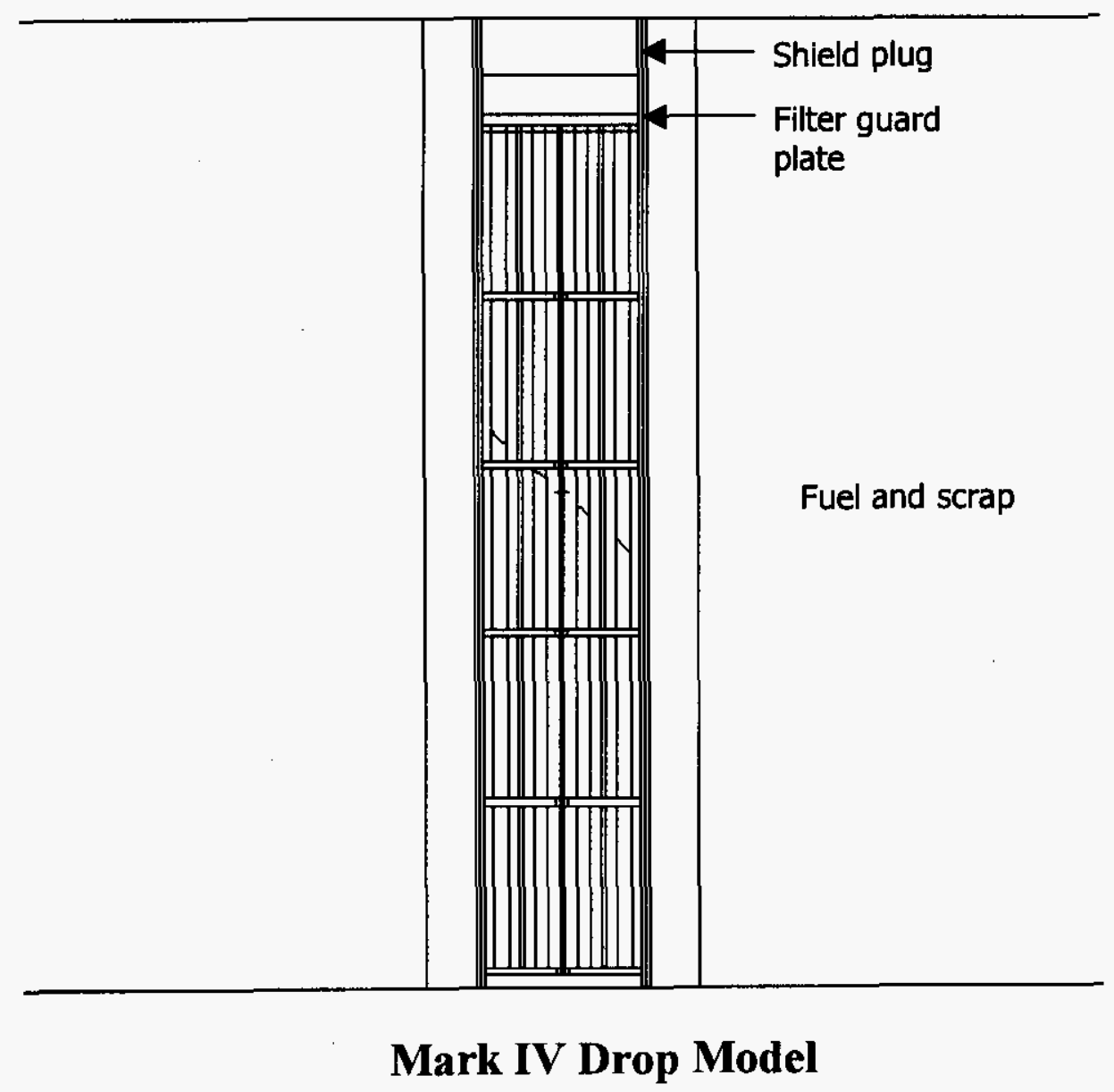




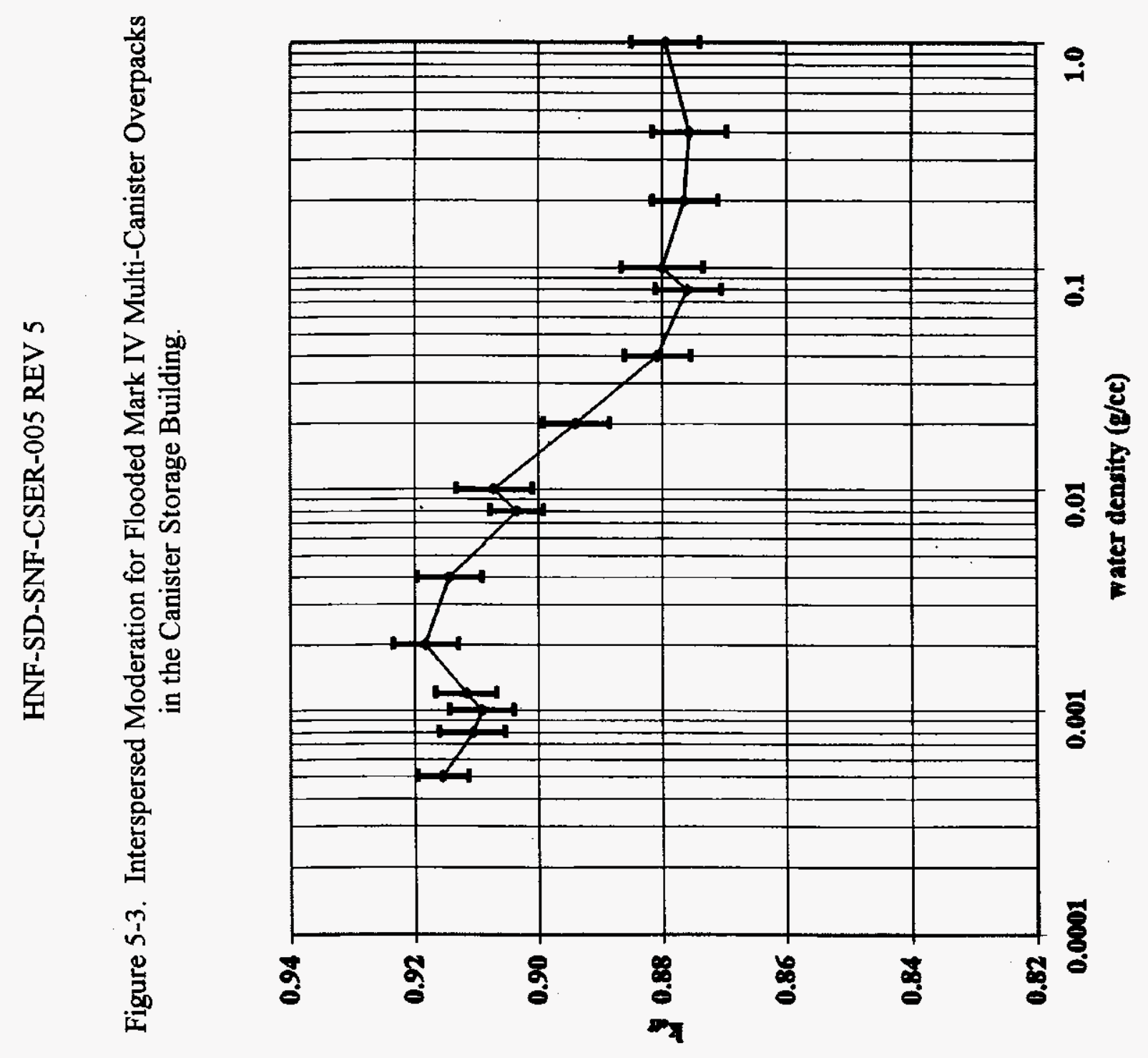

$\frac{2}{2}$ 
Figure 5-4. Interspersed Moderation for Dry Mark IV Multi-Canister Overpacks in the Canister Storage Building.

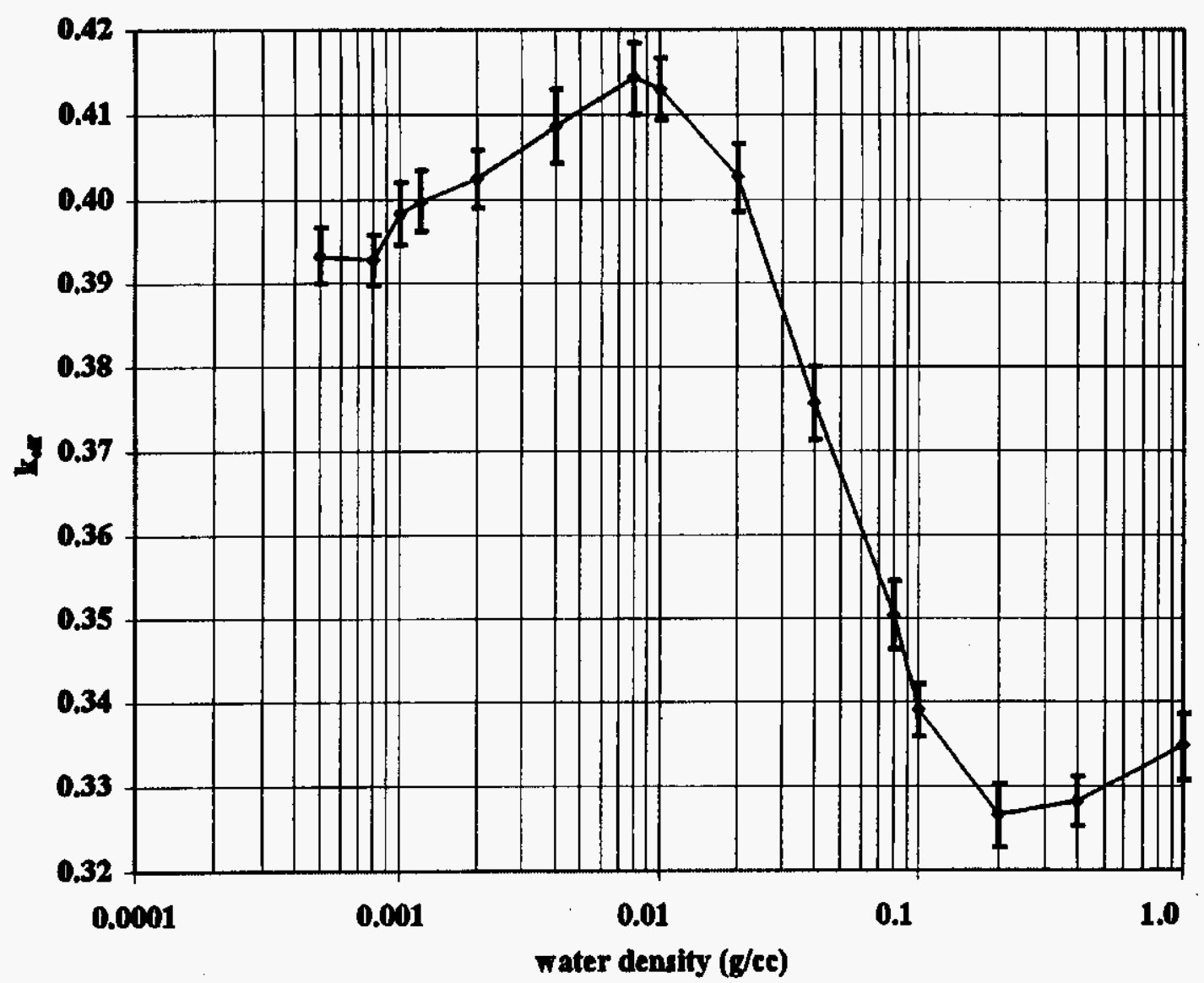


Figure 5-5. Water-Flooded Multi-Canister Overpack Loaded with Mark IV Fuel Being Lowered into a Canister Storage Building Storage Tube.

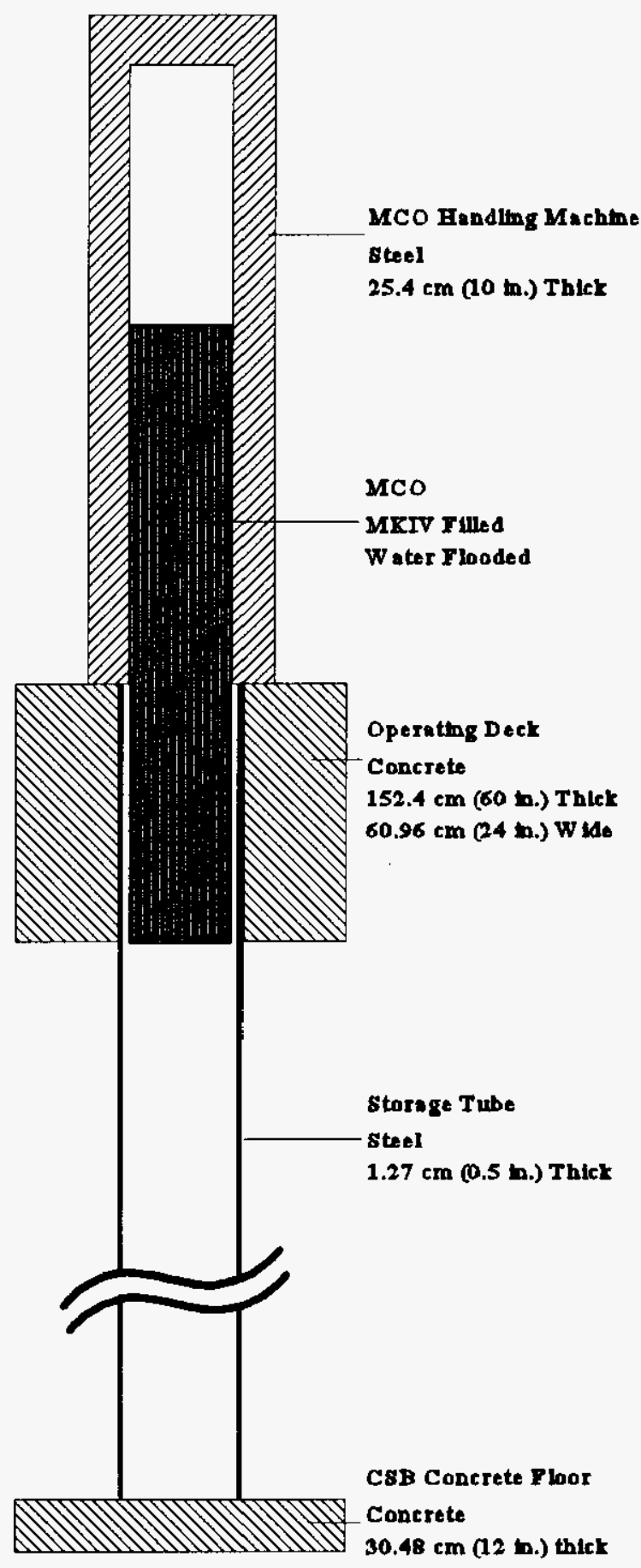


HNF-SD-SNF-CSER-005 REV 5

This page intentionally left blank. 
FLUOR DANLL NORTHWWS

TICERICAL PIRR REVIEWS

\section{CHICKLIST FOR TECENICAL PLER REVIEW}

Document Reviowed: HNF-SD-SNF-CSER-005, Rev, 5

Title: Criticality Safety Evaluation Report for the Multi-Canister Overpack

Author: S. F. Keasler

Date: October 13, 1999

Scope of Roview: Changes made and additions to Rev. 4 that resultod in Rov. 5.

YesNo*NA

[ x] [ ] I ]"Provious reviews complete and cover anslysis, up to scope of this roview, with no gape.

[x] [ ] [ ] Problem completely defined.

[x] [ ] [ ] Accident scenarios developed in a clear and logical manner.

[ x] [ ] [ ] Necessary assumptions explicitly statod and supported.

[x] [ ] [ ] Computer codes and data fles documented.

[x] [ ] [ ] Datn used in calculations explicitly stated in document.

[ x] [ ] [ ] Date checked for consintency with original source informntion as applicable.

[ ] [ ] [ $x$ ] Mathematical derivations checked including dimensional considtency of revalts.

[ x] [ ] [ ] Models appropriate and used within range of validity or use oustide of range of extablished validity justified.

[x] I ] [ ] Hand calculetions checked for errors. Spreadichect results hould be treated exactly the same as hand calculations.

[ x] [ ] [ ] Software input correct and consistent with document reviewed.

[ $x$ ] [ ] [ ] Software output consistent with input and with results reported in document reviewed.

[ x] [ ] [ ] Limits/criteriv/guidelines applied to analyais results are appropriate and referenced. Limits/criteria/guidelines checked against references.

[ x] I ] [ ] Safety margins consistent with good engineering practices.

[x] [ ] [ ] Conclusions consistent with analytical results and applicable limits.

[ x] [ 1 [ ] Results and conclusions address all points required in the problem statement

[x] [ ] [ ] Format consistent with applicable guides or other standards.

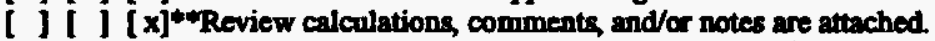

[x] [ ] [ ] Traceability

[x] [ ] [ ] Document approved (for example, the roviewer affirms the technical accuracy of the document).
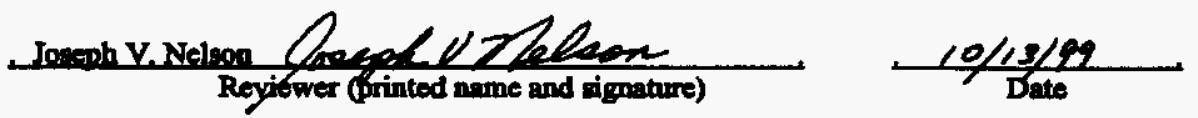

- All "no" responses must be explained below or on an aćl'tionsl freet.

** Any calculations, comments, or notes genernted as part of this roview should be signed, dated, and attached to this checklist. Such materint should be labeled and recorded in such a manner as to be intelligible to a technically qualified third party. 
HNF-SD-SNF-CSER-005 REV 5

This page intentionally left blank. 


\subsection{REFERENCES}

Breismeister, J. F., Editor, 1993, MCNP - A General Monte Carlo N-Particle Transport Code, Version 4A, Rev. 4A, LA-12625, Los Alamos National Laboratory, Los Alamos, New Mexico.

Burnside, R. J., G. H. Meriwether, A. H. Robinson, D. G. Erickson, and S. H. Finfrock, 1987, Procedures, Methods and Models for Neutronic Analysis of N Reactor, UNI-3894, UNC Nuclear Industries, Inc., Richland, Washington.

Carter, L. L., 1996, Certification of MCNP Version $4 A$ for WHC Computer Platforms, WHC-SD-MP-SWD-30001, Rev. 8, Westinghouse Hanford Company, Richland, Washington.

Chenault, D. M., 1998, Seismic Analysis of TN-DE\&SH Cask Transportation Trailer System for the CVD Facility, HNF-2179, Rev. 0, Fluor Daniel Hanford, Incorporated, Richland, Washington.

Edwards, W. S., 1997, Safety Analysis Report for Packaging (Onsite) Multicanister Overpack, HNF-SD-TP-SARP-017, Rev. 0, Fluor Daniel Hanford, Incorporated, Richland, Washington.

Erickson, D. G., 1998, Computer Code Validation Report 97-001: MCNP4B Plutonium Validation, HNF-1905, Rev. 1, Fluor Daniel Hanford, Incorporated, Richland, Washington.

Garvin, L. J., 1997, Spent Nuclear Fuel Project Path Forward Additional NRC Requirements, HNF-SD-SNF-DB-003, Rev. 4, Fluor Daniel Hanford, Incorporated, Richland, Washington.

Goldmann, L. H., 1998, Performance Specification for Spent Nuclear Fuel Multi-Canister Overpack, HNF-S-0426, Rev. 5, Fluor Daniel Hanford, Incorporated, Richland, Washington.

Gubbins, M. E., M. J. Roth, and C. J. Taubman, 1982, A General Introduction to the Use of the WIMS-E Modular Program, AEEW-R 1329, Reactor Physics Division, AEE Winfrith, England.

Hillesland, K. E., and K. N. Schwinkendorf, 1998, Installation Test Verification for MCNP4B, HNF-3317, Rev. 0, Fluor Daniel Hanford, Incorporated, Richland, Washington.

HNF-PRO-537, Criticality Safety Control of Fissionable Material, Fluor Daniel Hanford, Incorporated, Richland, Washington.

HNF-PRO-539, Criticality Safety Evaluations, Fluor Daniel Hanford, Incorporated, Richland, Washington. 
Holten, R. A., 1993, Interpretive Guidance for DOE 5480.24, Nuclear Criticality Safety (Letter to Contractors, Richland, Washington, December 20), Quality, Safety, and Health Programs Division, U.S. Department of Energy, Richland, Washington.

Kessler, S. F., 1998, Criticality Safety Evaluation Report for Multi-Canister Overpack Loading and Handling at the K Basins, HNF-2151, Rev. 0, Fluor Daniel Hanford, Incorporated, Richland, Washington.

Kessler, S. F., and S. H. Peck, 1999, Criticality Safety Evaluation Report for the K Basin Fuel Retrieval Subproject, HNF-SD-SNF-CSER-010, Rev. 0, Fluor Daniel Hanford, Incorporated, Richland, Washington.

Lamarsh, J. R., 1992, Nuclear Reactor Theory, Addison-Wesley Publishing Company, Incorporated, New York, New York.

Lorenz, B. D., 1999, Multi-Canister Overpack Topical Report, HNF-SD-SNF-SARR-005, Rev. 1, Fluor Daniel Hanford, Incorporated, Richland, Washington.

Makenas, B. J., 1998, Analysis of Sludge from Hanford K West Basin Canisters, HNF-1728, Rev. 0, Fluor Daniel Hanford, Incorporated, Richland, Washington.

Nelson, J. V., 1999, Criticality Safety Evaluation Report for the Cold Vacuum Drying Facility's Process Water Handling System, Rev. 2, Fluor Daniel Hanford, Incorporated, Richland, Washington.

Pajunen, A. L., 1998, Spent Nuclear Fuel Product Specification, HNF-SD-SNF-OCD-001, Rev. 2, Fluor Daniel Hanford, Incorporated, Richland, Washington.

Piepho, M. G., and R. D. Crowe, 1998, Thermal Analysis of Cold Vacuum Drying of Spent Nuclear Fuel, HNF-SD-SNF-CN-023, Rev. 1, Fluor Daniel Hanford, Incorporated, Richland, Washington.

Schmittroth, F., and R. Ruben, 1996, MCNP Criticality Validation and Bias for LEU Systems, WHC-SD-SNF-ANAL-013, Rev. 0, Westinghouse Hanford Company, Richland, Washington.

Schwinkendorf, K. N., 1994, Software Certification Package for the GOLF Code, WHC-SD-NR-SWD-024, Rev. 0, Westinghouse Hanford Company, Richland, Washington.

Schwinkendorf, K. N., 1995, Criticality Safety Evaluation Report for 300 Area N Reactor Fuel Fabrication and Storage Facility, WHC-SD-NR-CSER-010, Rev. 1, Westinghouse Hanford Company, Richland, Washington.

Schwinkendorf, K. N., 1998, Software Certification Report for MCNP4B, HNF-3316, Rev. 0, Fluor Daniel Hanford, Incorporated, Richland, Washington. 


\section{HNF-SD-SNF-CSER-005 REV 5}

Wittekind, W. D., 1993, Criticality Safety Evaluation K Basin Storage Rack Seismic Qualification, WHC-SD-NR-CSER-009, Rev. 0, Westinghouse Hanford Company, Richland, Washington. 
HNF-SD-SNF-CSER-005 REV 5

This page intentionally left blank. 
HNF-SD-SNF-CSER-005 REV 5

APPENDIX A

VALIDATION OF CALCULATIONAL METHODS 
HNF-SD-SNF-CSER-005 REV 5

This page intentionally left blank. 


\section{APPENDIX A}

\section{VALIDATION OF CALCULATIONAL METHODS}

\section{A.1 BENCHMARK EXPERIMENTS AND APPLICABILITY}

Benchmark experiments are primarily utilized to confirm two aspects of the neutron transport analysis tool:

- That the computer code has a sound treatment of the neutron transport.

- That the nuclear cross section database used in the transport code is in agreement with the relevant integral experiments.

The MCNP computer code (Breismeister 1993, Carter 1996) is used worldwide and has been extensively tested with its ENDF/B-V-based cross sections. The code development group at Los Alamos National Laboratory, where MCNP was developed, also has a set of 25 calculational benchmarks that extensively test various options within the code. These 25 benchmarks are used to confirm that new versions of the code give answers equivalent to those in previous versions, and that executables for users at other sites give exactly the same answer. Hence, the 25 calculational benchmarks supplement additional calculations made on experimental benchmarks.

MCNP validation efforts specifically appropriate for low-enriched uranium metal systems have been made to cover N Reactor fuel elements in water (Wittekind 1991; Wittekind 1992; Wittekind 1993) and low-enriched uranium solutions (Wittekind 1994). The calculational bias has also been determined (Schmittroth and Ruben 1996). The methodology of applying the bias and uncertainty is discussed in Section 3.2 .

The WIMS-E code (Gubbins et al. 1982) was used in this analysis to illustrate trends while the detailed three-dimensional criticality calculations were performed using MCNP. WIMS-E also has been extensively validated against critical experimental data. Previous validation efforts have covered low-enriched uranium metal billets (Erickson 1992; Schwinkendorf 1985a; Schwinkendorf 1985b), Mark IA fuel assemblies and uranium metal rods (Schwinkendorf 1992a), and low-enriched uranium solutions (Schwinkendorf 1992b; Wittekind 1992).

\section{A1.1 Details of Benchmark Calculations}

\section{MCNP Benchmark Calculations}

MCNP has been tested extensively, but the focus here is on a series of benchmark calculational comparisons (Whalen et al. 1991) with experiments that were made at Los Alamos National Laboratory. The first and second series of the comparisons in MCNP: Neutron Benchmark Problems (Whalen et al. 1991) were made to confirm agreement with experiments for 
fixed source calculations. The third series was for comparison with critical assemblies. These calculations included comparisons for fast neutron systems (Godiva and Jezebel assemblies), for low-enriched uranium systems, for graphite and water-reflected systems, and for interactive (array) units. The powerful geometry features in MCNP were used to model these systems in detail.

\section{WIMS-E Benchmark Calculations}

The uranium metal rods validation included critical experimental data from two sources. The first source (Hellens and Honeck 1962) contained data for $1.0 \mathrm{wt} \%{ }^{233} \mathrm{U}$-enriched rods and included measured boron poison effects. The published results were in the form of bucklings, not critical masses or $k_{\text {eff }}$ In order to compare WIMS-E results to the published results, WIMS-E results were output as two-group lattice-averaged cross sections for each experiment, and an analytical formula was used to calculate buckling for each case. WIMS-E results compared very well with experimental results, both as a function of water-to-uranium volume ratio and as a function of amount of poison added. The second source (Kupinski and Toffer 1970) contained data over a range of rod outside diameters $(0.444 \mathrm{~cm}$ [0.175 in.] outside diameter to $7.62 \mathrm{~cm}$ [3.0 in.] outside diameter) and ${ }^{235} \mathrm{U}$ enrichments $\left(3.0 \mathrm{wt} \%{ }^{235} \mathrm{U}\right.$ to $\left.4.89 \mathrm{wt} \%{ }^{235} \mathrm{U}\right)$. These results were in the form of critical masses in spherical and cylindrical geometry. Validations for the earlier version of the code, WIMS-D, document comparisons with annular uranium metal tubes over a range of enrichments from $0.947-w t \%{ }^{235} \mathrm{U}$ to $2.1-w t \%{ }^{235} \mathrm{U}$ (Schwinkendorf 1985a).

\section{A1.2 Results of Benchmark Calculations}

Agreement between the MCNP code and experiments for $\mathrm{k}_{\text {eff }}$ was within $1 \%$ for all of the critical systems referenced in Whalen et al. (1991). The MCNP N Reactor fuel bias was determined to be $-0.4 \mathrm{mk}$ (Schmittroth 1996). This means that MCNP would calculate $\mathrm{k}_{\text {eff }}$ about $0.4 \mathrm{mk}$ less than experimental measurements would calculate it.

WIMS-E tends to follow critical experimental data more accurately than WIMS-D but is still conservative. Therefore, it has been the practice to neglect the imposition of a bias when using WIMS-E to calculate $k_{\infty}$; buckling, or cross sections that are input to a diffusion theory code (to calculate idealized, finite dimensions). Inclusion of the bias would reduce the degree of conservatism in the result.

\section{A.2 RESULTS OF ROD AND CYLINDER COMPARISONS}

This criticality safety evaluation report treats a random arrangement of scrap as a lattice of uranium rods in water. A series of MCNP calculations have been performed to determine whether a regular lattice in cylindrical geometry will necessarily produce a bounding $\mathrm{k}_{\infty}$ for any arbitrarily shaped chunk of material, whether an explicit spherical lattice will optimize to a higher $\mathbf{k}_{\infty}$ and if it does, then how one would bound irregular lattice geometries. These MCNP calculations compared a hexagonal rod lattice with a three-dimensional lattice based on spheres 
arranged in a face-centered-cubic geometry. The fissionable material assumed was uranium metal with an enrichment equal to $0.95 \mathrm{wt} \%{ }^{235} \mathrm{U}$. For both rods and spheres, a double parameter search was made to find the maximum $\mathrm{k}_{\infty}$ (as the spacing was varied) as a function of uranium chunk diameter. The results indicate that even though the maximum $\mathrm{k}_{\infty}$ may occur for slightly different diameters, the maximized value for $k_{\infty}$ was essentially the same (well within the $1 \sigma$ uncertainty in the calculation). The use of rod lattices to model scrap is therefore considered to be appropriate.

\section{A.3 REFERENCES}

Breismeister, J. F., Editor, 1993, MCNP - A General Monte Carlo N-Particle Transport Code, Version 4A, LA-12625, Los Alamos National Laboratory, Los Alamos, New Mexico.

Carter, L. L., 1996, Certification of MCNP Version 4 A for WHC Computer Platforms, WHC-SD-MP-SWD-30001, Rev. 8, Westinghouse Hanford Company, Richland, Washington.

Erickson, D. G., 1992, WIMS-E Critical Mass Validation for 1.95 wt\% and 3.85 wt\% Uranium Billets, WHC-SD-NR-CSER-004, Rev. 0, Westinghouse Hanford Company, Richland, Washington.

Gubbins, M. E., M. J. Roth, and C. J. Taubman, 1982, A General Introduction to the Use of the WIMS-E Modular Program, AEEW-R 1329, Reactor Physics Division, AEE Winfrith, England.

Hellens, R. L., and H. C. Honeck, 1962, "A Summary and Preliminary Analysis of the BNL Slightly Enriched Uranium, Water Moderated Lattice Measurements," Light Water Lattices, Brookhaven National Laboratory, International Atomic Energy Agency, Vienna, Austria.

Kupinski, A. F., and H. Toffer, 1970, Use of the HAMMER System for Evaluating Light-Water Moderated, Critical Assemblies, DUN-7286, Douglas United Nuclear, Richland, Washington.

Schmittroth, F., and R. Ruben, 1996, MCNP Criticality Validation and Bias for LEU Systems, WHC-SD-SNF-ANAL-013, Rev. 0, Westinghouse Hanford Company, Richland, Washington.

Schwinkendorf, K. N., 1985a, WIMS Critical Mass Validation for 1.95 wt\% and 3.85 wt\% Uranium Billets, UNI-3486, UNC Nuclear Industries, Incorporated, Richland, Washington.

Schwinkendorf, K. N., 1985b, Validation of the WIMS Code for Tubular Uranium Fuel Elements, UNI-SA-142, UNC Nuclear Industries, Incorporated, Richland, Washington. 
Schwinkendorf, K. N., 1992a, Criticality Safety Evaluation Report, 105-KE Basin Fuel Encapsulation, WHC-SD-NR-CSER-007, Rev. 1, Westinghouse Hanford Company, Richland, Washington.

Schwinkendorf, K. N., 1992b, Validation of WIMS-E for Prediction of Uranium, Plutonium Nitrate Solution Critical Masses, WHC-IP-0840-FMEF, Westinghouse Hanford Company, Richland, Washington.

Whalen, D. J., D. A. Cardon, J. L. Uhle, and J. S. Hendricks, 1991, MCNP: Neutron Benchmark Problems, LA-12212, Los Alamos National Laboratory, Los Alamos, New Mexico.

Wittekind, W. D., 1991, N Reactor Spent Fuel Compacted Storage Criticality Calculations, WHC-SD-NR-CSA-004, Westinghouse Hanford Company, Richland, Washington.

Wittekind, W. D., 1992, K Basin Criticality Evaluation for Irradiated Fuel Canisters in Sludge, WHC-SD-NR-CSER-001, Rev. 0, Westinghouse Hanford Company, Richland, Washington.

Wittekind, W. D., 1993, Criticality Safety Evaluation K Basin Storage Rack Seismic Qualification, WHC-SD-NR-CSER-009, Rev. 0, Westinghouse Hanford Company, Richland, Washington.

Wittekind, W. D., 1994, MCNP Calculations of K-Infinity for 100KE Basin Sludge Samples, WHC-SD-NR-CSER-008, Rev. 1, Westinghouse Hanford Company, Richland, Washington. 
HNF-SD-SNF-CSER-005 REV 5

\section{APPENDIX B}

\section{SENSITIVITY STUDIES}


HNF-SD-SNF-CSER-005 REV 5

This page intentionally left blank. 


\section{APPENDIX B}

\section{SENSITIVITY STUDIES}

A number of design variable uncertainties (i.e., an assortment of fuel assembly lengths, unresolved cask dimensions, and degree of fuel corrosion) affect the reactivity of a multi-canister overpack (MCO). These uncertainties are addressed in this appendix.

Base case calculations discussed in Section 4.5 were performed with conservative assumptions, such as long lengths for Mark IV and Mark IA fuel assemblies, extremes of unresolved design dimensions, and optimum or full moderator densities. The following cases show the relationship of MCO reactivity to several design variables.

\section{B.1 FUEL LENGTH}

Both the Mark IA and Mark IV fuel assemblies were manufactured in discrete lengths. The longest Mark IA and Mark IV fuel assemblies are 26.1 in long. Only twelve of the 26.1-in.-long Mark IA assemblies are stored in the $\mathrm{K}$ Basins. For this criticality safety evaluation report, the maximum length of a Mark IA assembly is assumed to be 20.88 in. All the cases in Table B-1 represent flooded MCOs loaded with Mark IA fuel assemblies in the four central baskets, with assembly length varied, and Mark IA scrap in the top and bottom baskets. The cases in Table B-2 represent flooded MCOs loaded with Mark IV fuel assemblies in the three central baskets, with assembly length varied, and Mark IV scrap in the top and bottom baskets. The results show a modest sensitivity to the fuel length variations. The maximum $k_{\text {eff }}$ for a Mark IA-loaded MCO occurs at a fuel length of 19.6 in. Mark IV fuel reactivity decreased for all lengths shorter than $26.1 \mathrm{in}$, with a maximum decrease of about $7 \mathrm{mk}$ for the fuel length corresponding to $23.2 \mathrm{in}$. ( $1 \mathrm{mk}$ is a 0.001 change in $\mathrm{k}_{\text {eff }}$ ).

\section{B.2 MASS CHANGE CAUSED BY FUEL CORROSION}

The next two sets of sensitivity cases involve counteracting situations involving fuel mass lost from the upper baskets because of corrosion and fuel mass added to the lower baskets because of uranium oxide particles dropping from upper baskets. The second set of cases investigates the reactivity effect of fuel mass redistribution, which was modeled as a conservative uniform mass increase in the MCO's central intact fuel baskets.

Fuel mass will be lost from damaged fuel because of corrosion and the removal of that corrosion during cleaning of the fuel in the K Basins before it is loaded into the MCOs. The effect on reactivity of this fuel mass loss is shown in cases ocvd4.11, ocvd4.12, and ocvd4.13 in Table B-3. In these cases, uniform loss of mass in a Mark IV MCO was modeled as density reductions of $10 \%, 20 \%$, and $30 \%$. The reactivities of these cases show a slight and uncertain effect on reactivity for uniform mass loss at and below $20 \%$. The results show a definite decrease of about $9 \mathrm{mk}$ in reactivity corresponding to a decrease in fuel density of $30 \%$. 
Table B-1. Sensitivity Study for Varying Lengths of Mark IA Fuel.

\begin{tabular}{|c|c|c|c|c|}
\hline Case & Fuel length $(\mathrm{cm})$ & $\mathrm{k}_{\text {calc }}$ & $\sigma$ & $\mathrm{k}_{\text {off }}$ \\
\hline ocvd1.1 & 53.08 & 0.8826 & 0.0031 & 0.8933 \\
\hline ocvd4.1 & 49.8 & 0.8877 & 0.0036 & 0.8988 \\
\hline ocvd4.2 & 37.8 & 0.8808 & 0.0031 & 0.8915 \\
\hline
\end{tabular}

Table B-2. Sensitivity Study for Varying Lengths of Mark IV Fuel.

\begin{tabular}{|c|c|c|c|c|}
\hline Case & Fuel length $(\mathrm{cm})$ & $\mathrm{k}_{\text {calc }}$ & $\sigma$ & $\mathrm{k}_{\text {eff }}$ \\
\hline ocvd1.2 & 66.3 & 0.8894 & 0.0023 & 0.8995 \\
\hline ocvd4.3 & 62.5 & 0.8837 & 0.0024 & 0.8939 \\
\hline ocvd4.4 & 58.9 & 0.8817 & 0.0034 & 0.8926 \\
\hline ocvd4.5 & 44.2 & 0.8852 & 0.0028 & 0.8956 \\
\hline
\end{tabular}

Table B-3. Sensitivity Study for Mass Reduction.

\begin{tabular}{|c|l|c|c|c|}
\hline Case & \multicolumn{1}{|c|}{ Mass change } & $\mathrm{k}_{\text {calc }}$ & $\sigma$ & $\mathrm{k}_{\text {eff }}$ \\
\hline ocvd1.2 & Normal load & 0.8894 & 0.0023 & 0.8995 \\
\hline ocvd4.11 & Three baskets of intact fuel mass reduced by $10 \%$ & 0.8891 & 0.0028 & 0.8995 \\
\hline ocvd4.12 & Three baskets of intact fuel mass reduced by $20 \%$ & 0.8883 & 0.0032 & 0.8991 \\
\hline ocvd4.13 & Three baskets of intact fuel mass reduced by $30 \%$ & 0.8808 & 0.0029 & 0.8913 \\
\hline ocvd4.14 & $\begin{array}{l}\text { Three baskets of intact fuel mass increased by } \\
100 \mathrm{~kg} \mathrm{UO}_{2}\end{array}$ & 0.8767 & 0.0029 & 0.8872 \\
\hline ocvd4.15 & $\begin{array}{l}\text { Three baskets of intact fuel mass increased by } \\
200 \mathrm{~kg} \mathrm{UO}_{2}\end{array}$ & 0.8624 & 0.0030 & 0.8730 \\
\hline ocvd4.16 & $\begin{array}{l}\text { Three baskets of intact fuel mass increased by } \\
300 \mathrm{~kg} \mathrm{UO}_{2}\end{array}$ & 0.8582 & 0.0027 & 0.8686 \\
\hline
\end{tabular}


Fuel mass in each of the three baskets of intact fuel was assumed to be increased by uranium oxide dropped from corroded Mark IV fuel and Mark IV fuel scrap in the upper baskets and redistributed in the interstitial regions between the fuel assemblies and in the coolant channels of the fuel assemblies. The effect on reactivity of this fuel mass increase is shown in cases ocvd4.14, ocvd4.15, and ocvd4.16 in Table B-3. In these cases, a uniform mass of $100 \mathrm{~kg}, 200 \mathrm{~kg}$, and $300 \mathrm{~kg}$ of additional $\mathrm{UO}_{2}$ was modeled as being distributed in the central three fuel baskets. The reactivities of these cases show a progressive decrease in $\mathrm{k}_{\text {eff }}$ with increasing $\mathrm{UO}_{2}$ mass when compared with case ocvd1.2.

\section{B.3 SHIPPING CASK ANNULUS THICKNESS}

The effect of cask annulus water thickness on reactivity was investigated. The reactivities were determined in cases ocvd4.17 through ocvd4.21 in Table B-4 for a Mark IV MCO. Case ocvd4.17 assumed no cask annulus gap, and cases ocvd4.18 through ocvd4.21 assumed progressive increments of $0.5 \mathrm{in}$. above the base case thickness of $0.5 \mathrm{in}$. The results in these cases showed that the reactivity progressively decreased with increasing cask annulus thickness.

Table B-4. Sensitivity Study for Change in Cask Annulus Thickness.

\begin{tabular}{|c|l|c|c|c|}
\hline Case & \multicolumn{1}{|c|}{ Cask annulus thickness } & $\mathrm{k}_{\text {calc }}$ & $\sigma$ & $\mathrm{k}_{\text {eff }}$ \\
\hline ocvd1.2 & Normal annulus & 0.8894 & 0.0023 & 0.8995 \\
\hline ocvd4.17 & 0.5 -in. decrease of cask annulus region & 0.8991 & 0.0028 & 0.9095 \\
\hline ocvd4.18 & 0.5 -in. increase of cask annulus region & 0.8829 & 0.0028 & 0.8933 \\
\hline ocvd4.19 & 1.0 -in. increase of cask annulus region & 0.8793 & 0.0030 & 0.8899 \\
\hline ocvd4.20 & 1.5-in. increase of cask annulus region & 0.8776 & 0.0036 & 0.8887 \\
\hline ocvd4.21 & 2.0-in. increase of cask annulus region & 0.8707 & 0.0031 & 0.8814 \\
\hline
\end{tabular}

\section{B.4 WATER LEVEL AND DENSITY}

Several calculations have been performed to address changes in water level within the MCO. Both fully flooded and dry cases have been evaluated, as well as intermediate water densities that span the range from fully flooded to dry. As water density decreases inside the MCO, the $\mathrm{k}_{\text {eff }}$ of the system decreases rapidly, as shown in Figure B-1. In this study, the water density outside the $\mathrm{MCO}$ is held constant at $1.0 \mathrm{~g} / \mathrm{cm}^{3}$.

Figure B-2 shows the sensitivity of $\mathrm{k}_{\text {eff }}$ to changes in water density between MCO containers. As the water between MCO containers is reduced (with water density held constant at $1.0 \mathrm{~g} / \mathrm{cm}^{3}$ inside the $\mathrm{MCO}$ ), the $\mathrm{k}_{\text {eff }}$ does not change significantly. These results indicate that 
$\mathbf{k}_{\text {eff }}$ is far more sensitive to water density inside the MCO than to interspersed water density between MCOs. Without internal flooding, the $\mathrm{k}_{\text {eff }}$ of the MCO will always be less than 0.5 .

\section{B.5 PLUTONIUM DISTRIBUTION}

Optimal scrap is treated as unexposed fuel pieces with no plutonium buildup. One concern has been that plutonium buildup on the exterior surface of a fuel element might preferentially corrode off the element and contribute to more highly reactive scrap pieces in $\mathrm{K}$ Basin sludge. This question was addressed for waste streams sent to the Hanford Site tank farms (Rogers 1996). While enhanced plutonium buildup near the outer surface of nuclear fuel (not just Hanford Site reactor fuel) is well-known, the peaking factor, which may be defined as the plutonium concentration at the surface divided by the average plutonium concentration, is not much greater than a factor of two (see Appendix E).

Enhanced ${ }^{235} \mathrm{U}$ depletion also occurs at the fuel surface. Criticality is affected by both the ${ }^{239} \mathrm{Pu}$ buildup and the ${ }^{235} \mathrm{U}$ depletion. However, fuel corrosion tends to progress axially from damaged ends and not radially inward. Comparison of $1.25 \mathrm{wt} \%$ uranium and U-Pu solutions at optimal hydrogen-to-uranium metal atom ratios $(\mathrm{H} / \mathrm{U})$ illustrates the $\mathrm{U} / \mathrm{Pu}$ ratio required for equivalency. For a $\mathrm{k}_{\text {eff }}$ of 0.98 in hemispherical geometry, the minimum uranium mass required is $2,303 \mathrm{~kg}$ for $1.25 \mathrm{wt} \%$ enriched uranium solutions (Schwinkendorf 1995).

A parametric study was carried out for solutions of uranium and plutonium with varying H/U and U/Pu ratios (Erickson 1994). Table 2 of HNF-SD-NR-CSER-014, Criticality Safety Evaluation Report for the $100 \mathrm{KE}$ Basin Sandfilter Backwash Pit (Erickson 1994), contains calculated minimum masses for $a \mathrm{k}_{\text {eff }}$ of 0.98 as a function of $\mathrm{U} / \mathrm{Pu}$ ratio. These results are minimum because the $\mathrm{H} / \mathrm{U}$ ratio was optimized for each $\mathrm{U} / \mathrm{Pu}$ ratio. Interpolating between the tabulated data points, the U/Pu ratio required is 193 (minimum mass of $2,303 \mathrm{~kg}$ for a $\mathrm{k}_{\text {eff }}$ of 0.98 ), at which point the optimal $\mathrm{H} / \mathrm{U}$ ratio is approximately 7 . Therefore, as long as the $\mathrm{U} / \mathrm{Pu}$ ratio is greater than about 190 , the critical mass of optimized uranium-plutonium solution will be greater (and the solution less reactive) than for the optimized $1.25 \mathrm{wt} \%$ enriched uranium solution.

The uranium and plutonium isotopic breakdown assumed in HNF-SD-NR-CSER-014 (Erickson 1994) was based on measurements taken from the $100 \mathrm{KE}$ Basin sandfilter backwash pit and is considered representative of actual uranium and plutonium concentrations currently in the fuel storage basins. Furthermore, the measured U/Pu ratio was in excess of 300 and is expected, from N Reactor production tables (Hedengren 1987), to be 450, which also is consistent with WIMS-E burnup results shown in Appendix E. Therefore, treating fuel corrosion product sludge as $1.25 \mathrm{wt} \% \mathrm{UO}_{2}$ solution will bound any real corrosion product sludge arising from exposed fuel assemblies. The measured $\mathrm{U} / \mathrm{Pu}$ data indicate that plutonium buildup is insufficient to yield reactivity greater than the assumed $1.25 \mathrm{wt} \%$ enriched solution model. 


\section{B.6 LATTICE SPACING FOR INTACT FUEL ASSEMBLIES}

The MCO analyses reported in this criticality safety evaluation report use a center-to-center hexagonal spacing of 2.8 in. for fuel assemblies. The spacing is established by rings on the bottom of the fuel baskets. Previous analyses have shown that the optimal spacing of $\mathrm{N}$ Reactor fuel in water is around $3.1 \mathrm{in}$. Using a larger spacing than $2.8 \mathrm{in.}$ would make loading the MCO containers easier, but this would increase the reactivity of the lattice because the current design is undermoderated.

The effect of fuel assembly spacing was analyzed using the Monte Carlo n-particle transport code (MCNP) (Breismeister 1993, Carter 1996) for the geometric arrangement in Figure B-3, using various lattice spacings from $2.65 \mathrm{in}$. to $2.90 \mathrm{in}$. The axial arrangement is as shown in CASE1 (Figure B-4) but with both top and bottom scrap baskets replaced with intact fuel so that the effect is not overshadowed by the more reactive scrap material. A lattice spacing of $2.90 \mathrm{in}$. is only possible if the outermost 12 assemblies are removed, or they will impact the inner wall of the MCO. This reduced arrangement is shown in Figure B-5. The CASE1 MCNP model assumes an MCO inner diameter of $23.0 \mathrm{in}$., but the nominal value is only 22.625 in. Assuming this smaller value, the largest possible lattice spacing is just over 2.80 in., which is indicated in Figure B-6. Although an array of intact assemblies with a lattice spacing of 2.85 in. fits inside the MCNP model (with a 23.0-in. inner diameter), it will not fit inside the nominal 22.0625-in. inner diameter. For the 2.90-in. spacing, removal of 12 assemblies is required to fit the array inside the 23.0-in. MCNP model.

The nominal basket diameter is 22.625 in., and the internal diameter of the MCO is 23.25 in. The actual lattice spacing of $2.77 \mathrm{in}$. is conservatively approximated by $2.8 \mathrm{in}$. With the spacing of the bottoms of the fuel at $2.77 \mathrm{in}$., and the unrestrained tops at $2.8 \mathrm{in}$., the average spacing would be 2.785 in. The change in $k_{\text {eff }}$ for this change in lattice spacing ( 0.015 in.) is only 0.004 , derived from examination of the data shown in Figure B-6. This effect of increased fuel element spacing at the unrestrained tops of the intact fuel elements is small and will be neglected. Because decreasing the lattice spacing decreases the $\mathrm{k}_{\text {eff, }}$, ring spacing of less than 2.80-in. on the fuel bottom plates is covered conservatively by this analysis.

\section{B.7 EFFECT OF UNIFORM CHANGE IN LATTICE SPACING (PARTIAL ASSEMBLIES)}

A second set of MCNP calculations was completed to examine the reactivity effect of removing fuel to allow a greater lattice spacing. This set of calculations differs from the set described in the previous section by allowing the unrealistic situation of having partial assemblies in the outer row of the fuel basket. In Section C.6, if a whole assembly did not completely fit into the basket for a given lattice pitch, it was removed from the model. In the calculations described in this section, only that portion of an assembly that would not fit into the basket was removed from the model. 
This model is inherently a lower leakage geometry because fuel pieces and partial assemblies exist near the outer boundary where they can intercept neutrons that would otherwise have leaked out. The $\mathrm{k}_{\text {eff }}$ for the 2.8-in. spacing is therefore somewhat higher (by about $15 \mathrm{mk}$ ) than the Mark IA MCO base case, CASE1. Figures B-7 and B-8 illustrate the trend as lattice spacing is changed for the CASE1 and CASE2 geometries (Mark IV MCO), when the Mark IA and Mark IV intact fuel arrangements are replaced with arrangements that have partial assemblies filling the empty spaces seen in Figure B-5) between the outer row of intact assemblies and the basket boundary. These figures clearly show that $\mathrm{k}_{\text {eff }}$ is not sensitive to lattice spacing (the upper and lower scrap baskets in both of these models are driving the $k_{\text {eff }}$ of the system). If the top and bottom scrap baskets also are filled with the intact fuel lattice, the results are as shown in Figures B-9 and B-10.

MCOs loaded with only intact fuel are less reactive than MCOs loaded with the scrap baskets top and bottom. It is significant that even though Figures B-9 and B-10 show some increased reactivity with partially loaded baskets, when scrap baskets are loaded top and bottom, the reactivity of the system appears to be dominated by the scrap baskets. The increased reactivity attributable to partial fuel basket loading does not contribute significantly to the higher reactivity caused by the scrap baskets.

\section{B.8 REACTIVITY EFFECT OF FUEL TEMPERATURE}

The effect of temperature on reactivity was evaluated for both Mark IV and Mark IA fuel assemblies. The WIMS-E lattice code (Gubbins et al. 1982) was used to calculate lattice $\mathbf{k}_{\infty}$ and change in reactivity for both Mark IV and Mark IA fuel as a function of the temperature coefficient. The temperature coefficient may be approximated between two discrete temperatures using the following relationship:

$$
\left.\left.\alpha_{T} \equiv \frac{\partial \rho}{\partial T}\right|_{T} \approx \frac{\Delta \rho}{\Delta T}\right|_{T}=\frac{10^{5}\left(k_{\infty}(T+\Delta T)-k_{\infty}(T-\Delta T)\right)}{k_{\infty}(T+\Delta T) k_{\infty}(T-\Delta T)(2 \Delta T)} \mathrm{pcm} / \mathrm{K}
$$

The $10^{5}$ multiplier in the equation converts the raw reactivity, $\Delta \rho$, into units of $\mathrm{pcm}$, or percent milli-k. Figure B-11 illustrates the lattice $k_{\infty}$ and temperature coefficients for both of these fuel types. As expected, both $\mathrm{N}$ Reactor fuel types have negative temperature coefficients because they contain large percentages of ${ }^{238} \mathrm{U}$, which has a large negative Doppler coefficient. Mark IV fuel exhibits a slightly more negative temperature coefficient than Mark IA fuel because the ${ }^{238} \mathrm{U}$ content is greater. At room temperature (MCNP calculations reported here were performed at $300 \mathrm{~K}$ ), the temperature coefficients are approximately $-3 \mathrm{pcm} / \mathrm{K}$. As temperature increases, the magnitude of the temperature coefficients become smaller but they remain negative. 


\section{B.9 DIMENSIONAL TOLERANCE}

The effect of dimensional tolerance on reactivity was analyzed parametrically by a series of WIMS-E calculations. Table B-5 contains the radial dimension specifications for Mark IV and Mark IA fuel types (Jack 1988).

Table B-5. Radial Dimension Specifications for N Reactor Mark IV and Mark IA Fuel Assemblies.

\begin{tabular}{|c|c|c|}
\hline & Mark IA & Mark IV \\
\hline $\begin{array}{l}\text { Outer element: } \\
\text { Outer diameter } \\
\text { Inner diameter }\end{array}$ & $\begin{array}{l}2.391 \mathrm{in} \text { to } 2.416 \mathrm{in} . \\
1.754 \mathrm{in} \text {. to } 1.779 \mathrm{in} .\end{array}$ & $\begin{array}{l}2.410 \text { in. to } 2.435 \mathrm{in} . \\
1.691 \mathrm{in} \text {. to } 1.716 \mathrm{in} .\end{array}$ \\
\hline $\begin{array}{l}\text { Inner element: } \\
\text { Outer diameter } \\
\text { Inner diameter }\end{array}$ & $\begin{array}{l}1.237 \mathrm{in} \text { to } 1.256 \mathrm{in} . \\
0.431 \mathrm{in} \text { to } 0.450 \mathrm{in} .\end{array}$ & $\begin{array}{l}1.267 \mathrm{in} \text { to } 1.286 \mathrm{in} . \\
0.473 \mathrm{in} \text { to } 0.492 \mathrm{in} .\end{array}$ \\
\hline
\end{tabular}

Table B-6 shows the variation in lattice $k_{\infty}$ as the radial fuel dimensions are varied. Either minimum or maximum dimensions were selected to arrive at either minimum or maximum uranium fuel region thicknesses. In all cases, the fuel assemblies were placed in an infinite water lattice at optimal spacing. The sensitivity of reactivity to radial dimension tolerances has been shown to be less than $1 \mathrm{mk}$.

Table B 6. Sensitivity of Lattice k-Infinity to Radial Dimension Tolerances.

\begin{tabular}{|l|l|l|}
\hline & Mark IA & Mark IV \\
\hline Minimum uranium thickness & 1.131423 & 1.062878 \\
\hline Nominal uranium thickness & 1.132133 & 1.062349 \\
\hline Maximum uranium thickness & 1.132055 & 1.061646 \\
\hline
\end{tabular}

\section{B.10 ENRICHMENT TOLERANCE}

The effect of enrichment tolerance on reactivity was analyzed parametrically by a series of WIMS-E calculations. The enrichment tolerance for N Reactor fuel was equal to $0.006 \mathrm{wt} \%$ (Gant and Zilar 1977). 
Table B-7 shows the variation in lattice $\mathrm{k}_{\infty}$ as the fuel enrichment was either increased or decreased by $0.006 \mathrm{wt} \%{ }^{235} \mathrm{U}$. In all cases, the fuel assemblies were placed in an infinite water lattice at optimal spacing. The sensitivity of reactivity to enrichment tolerance has been shown to be approximately $\pm 2 \mathrm{mk}$ for a $\pm 0.006 \mathrm{wt} \%$ enrichment variation.

Table B-7. Sensitivity of Lattice k-Infinity to Enrichment Tolerances.

\begin{tabular}{|l|l|l|}
\hline & \multicolumn{1}{|c|}{ Mark IA } & \multicolumn{1}{c|}{ Mark IV } \\
\hline Minimum uranium enrichment & 1.130463 & 1.060261 \\
\hline Nominal uranium enrichment & 1.132133 & 1.062349 \\
\hline Maximum uranium enrichment & 1.133780 & 1.064408 \\
\hline
\end{tabular}

\section{B.11 REACTIVITY EFFECT OF PACKING FRACTION (WATER-TO-FUEL RATIO)}

The packing fraction is the volume fraction of fuel in the unit lattice. An optimal packing fraction was used for scrap, with both size and spacing varied to maximize reactivity. The packing fraction varies according to enrichment but is equal to 0.320 for Mark IV scrap and 0.294 for Mark IA scrap.

\section{B.12 MARK IV BASKET BASEPLATE WEIGHT}

The baseplates are assumed in the MCNP input model to be solid (the holes are not explicitly modeled). CASE4 was modeled assuming that 0.375 -in. stainless steel baseplates formed the bottom of the scrap baskets. Given the diameter of the baseplate, this model includes nearly $50 \mathrm{lb}$ of steel. In reality, the baseplate weighs only $27.13 \mathrm{lb}$ because it is perforated. Therefore, the model was modified by reducing the density of the baseplate material. The results are shown in Table B-8

Table B-8. Sensitivity Study for Baseplate Thickness.

\begin{tabular}{|c|l|c|c|c|}
\hline \multicolumn{1}{|c|}{ Case } & \multicolumn{1}{|c|}{ Basket baseplate weight } & $\mathrm{k}_{\text {calc }}$ & $\sigma$ & $\mathrm{k}_{\text {eff }}$ \\
\hline CASE 4 & $50 \mathrm{lb}$ & 0.9344 & 0.0028 & 0.9448 \\
\hline $\begin{array}{l}\text { CASE 4 } \\
\text { modified }\end{array}$ & $27.13 \mathrm{lb}$ & 0.9329 & 0.0027 & 0.9433 \\
\hline
\end{tabular}


The removal of neutron-absorbing material (reduced steel density in the scrap basket baseplate) from the MCNP model should have increased the $\mathrm{k}_{\text {eff }}$ of the system. However, this change in the model is so slight that MCNP was not able to discern a statistically significant difference in the neutron multiplication constants between the two cases. The difference between the two $\mathrm{k}_{\text {eff }}$ values is only one-third of the 1-sigma statistical uncertainty in the two cases. The conclusion is that, within the statistical uncertainty in the MCNP results, there is no statistically significant difference between modeling the scrap basket baseplates at full density (as if they were not perforated) or at reduced density (to account for the perforations).

\section{B.12 REFERENCES}

Breismeister, J. F., Editor, 1993, MCNP - A General Monte Carlo N-Particle Transport Code, Version 4A, LA-12625, Los Alamos National Laboratory, Los Alamos, New Mexico.

Carter, L. L., 1996, Certification of MCNP Version 4A for WHC Computer Platforms, WHC-SD-MP-SWD-30001, Rev. 8, Westinghouse Hanford Company, Richland, Washington.

Erickson, D. G., 1994, Criticality Safety Evaluation Report for the $100 \mathrm{KE}$ Basin Sandfilter Backwash Pit, WHC-SD-NR-CSER-014, Rev. 1, Westinghouse Hanford Company, Richland, Washington.

Gant, R. G., and J. A. Zilar, 1977, Specifications for Uranium Metal Billets for N Reactor Fuel Elements, UNI-M-22, Rev. 1, United Nuclear Industries, Inc., Richland, Washington.

Gubbins, M. E., M. J. Roth, and C. J. Taubman, 1982, A General Introduction to the Use of the WIMS-E Modular Program, AEEW-R 1329, Reactor Physics Division, AEE Winfrith, England.

Hedengren, D. C., and H. J. Goldberg, 1987, ORIGEN2 Predictions of N Reactor Fuel Actinide Composition, SD-CP-TI-105, Rev. 0, Rockwell Hanford Operations, Richland, Washington.

Jack, M. L., 1988, NUSAR - N Reactor Updated Safety Analysis Report, WHC-EP-0240, Vol. 3, Westinghouse Hanford Company, Richland, Washington.

Rogers, C. A., K. N., Schwinkendorf, and H. Harris, 1996, Criticality Parameters for Tank Waste Evaluation, WHC-SD-SQA-CSA-507, Rev. 0, Westinghouse Hanford Company, Richland, Washington.

Schwinkendorf, K. N., 1995, Criticality Safety Evaluation Report for 300 Area N Reactor Fuel Fabrication and Storage Facility, WHC-SD-NR-CSER-010, Rev. 1, Westinghouse Hanford Company, Richland, Washington. 
Figure B-1. Interspersed Moderation: Water Density Variation Inside Multi-Canister Overpack.

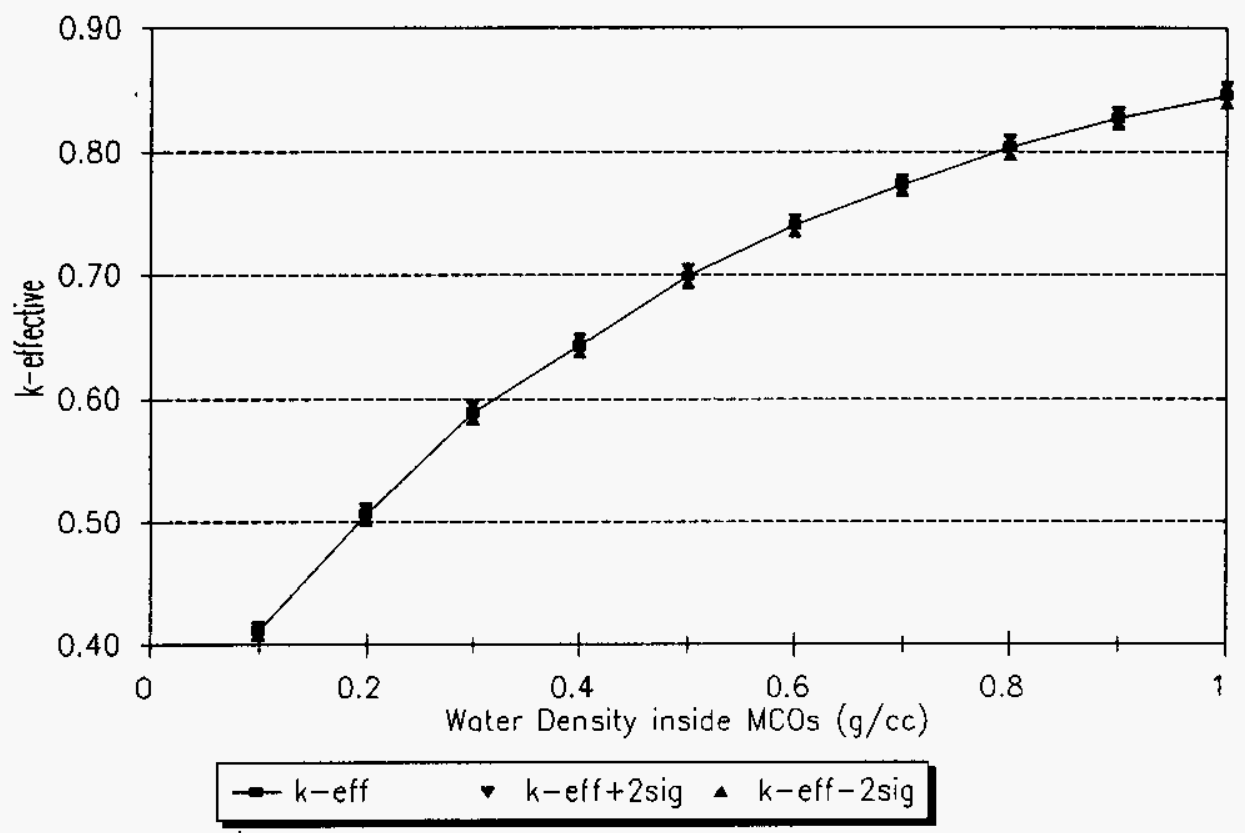

Figure B-2. Interspersed Moderation: Water Density Variation Outside Multi-Canister Overpack.

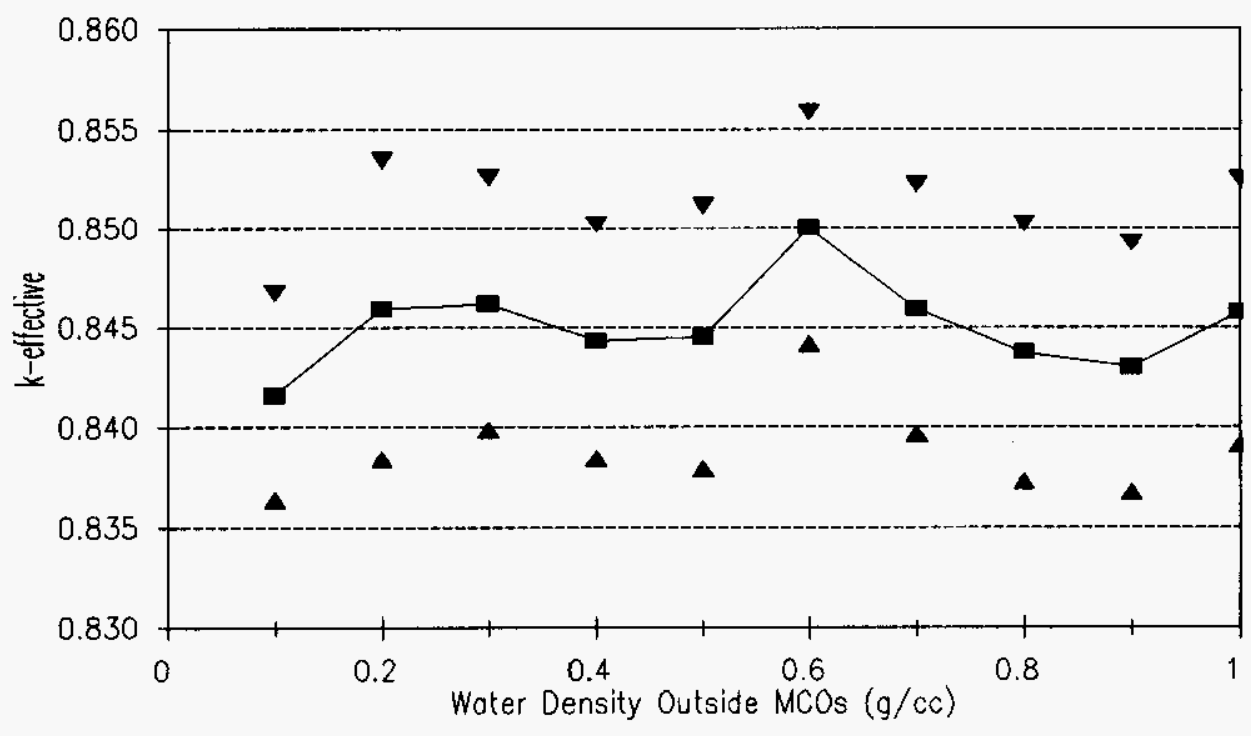

$-k$-eff $\quad \boldsymbol{v}$-eff $+2 \operatorname{sig} \Delta k-e f f-2 \operatorname{sig}$ 


\section{HNF-SD-SNF-CSER-005 REV 5}

Figure B-3. Loading Arrangement for Mark IA Fuel in Multi-Canister Overpack in Cask.

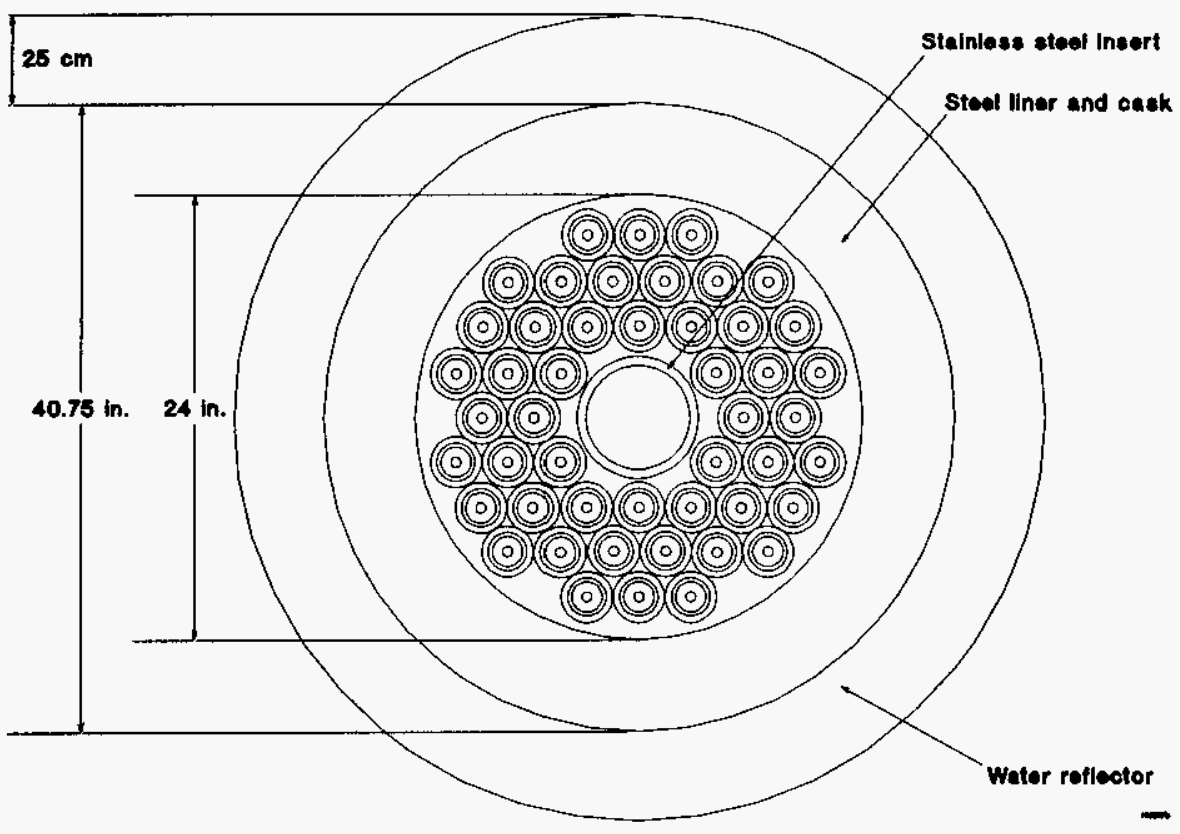


Figure B-4. Input Models CASE 1 and CASE 2: Axial Geometry.
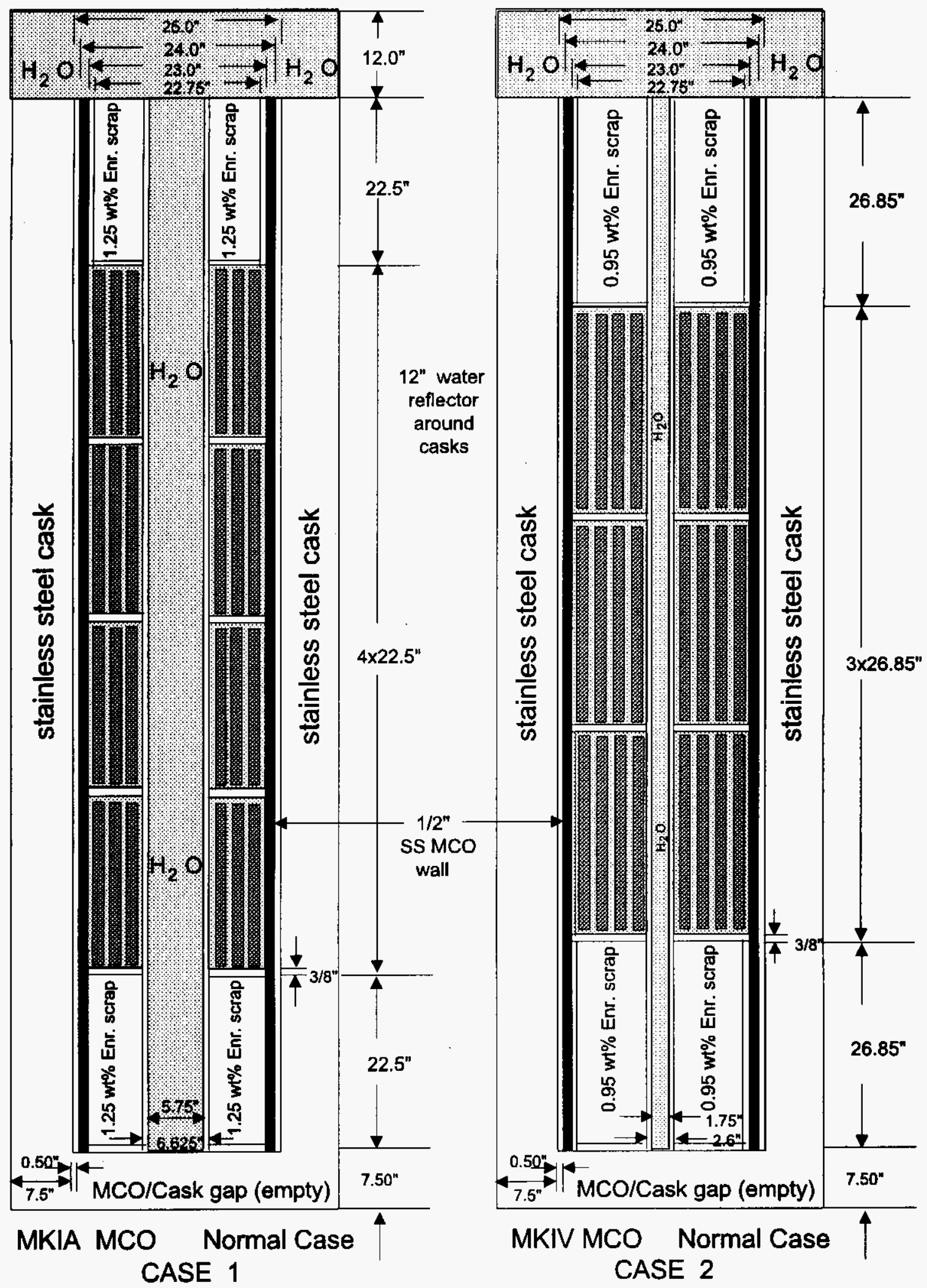


\section{HNF-SD-SNF-CSER-005 REV 5}

Figure B-5. Reduced Loading for Mark IA Fuel in Multi-Canister Overpack (12 Assemblies Removed).

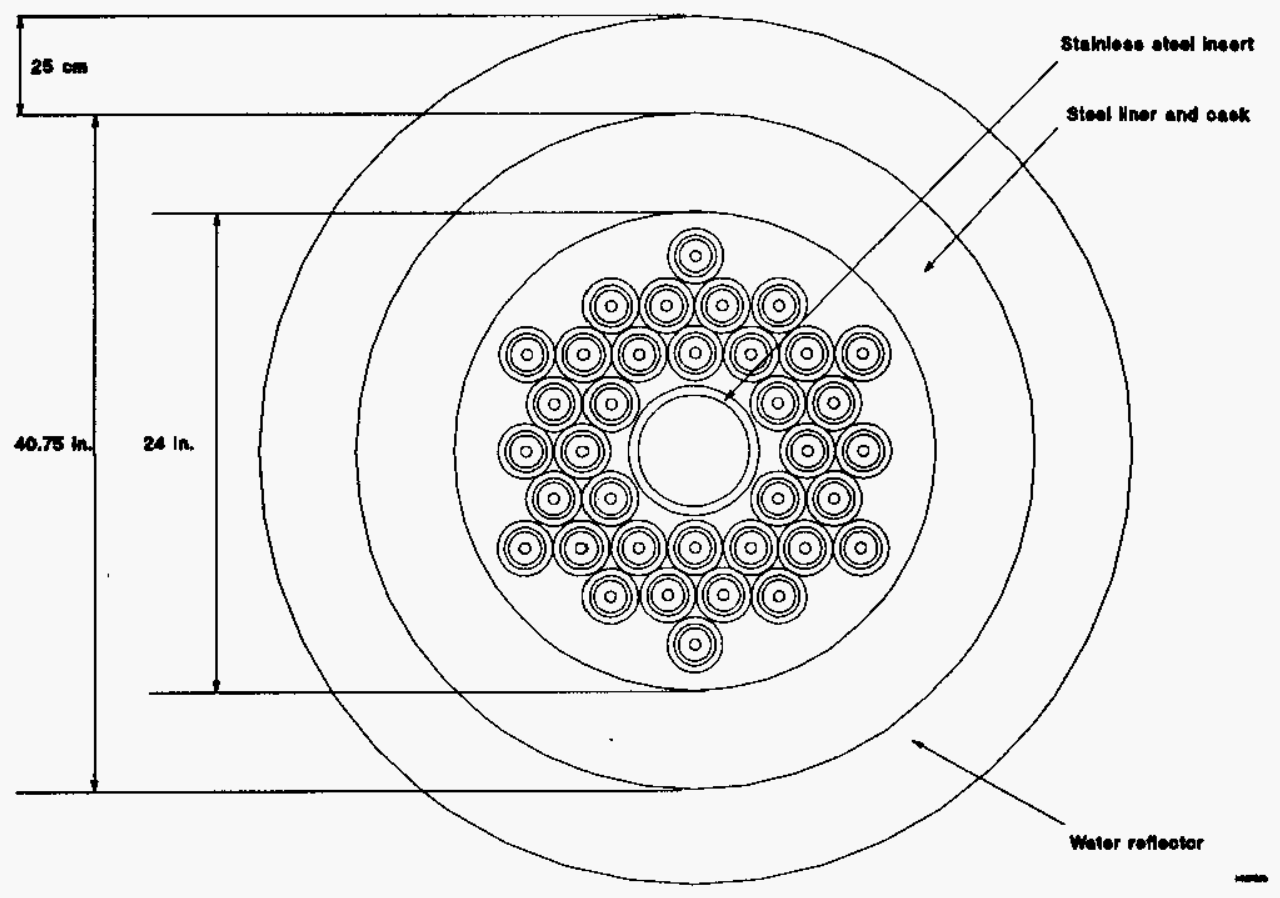

Figure B-6. k-Effective Versus Lattice Spacing for Mark IA Fuel Assemblies.

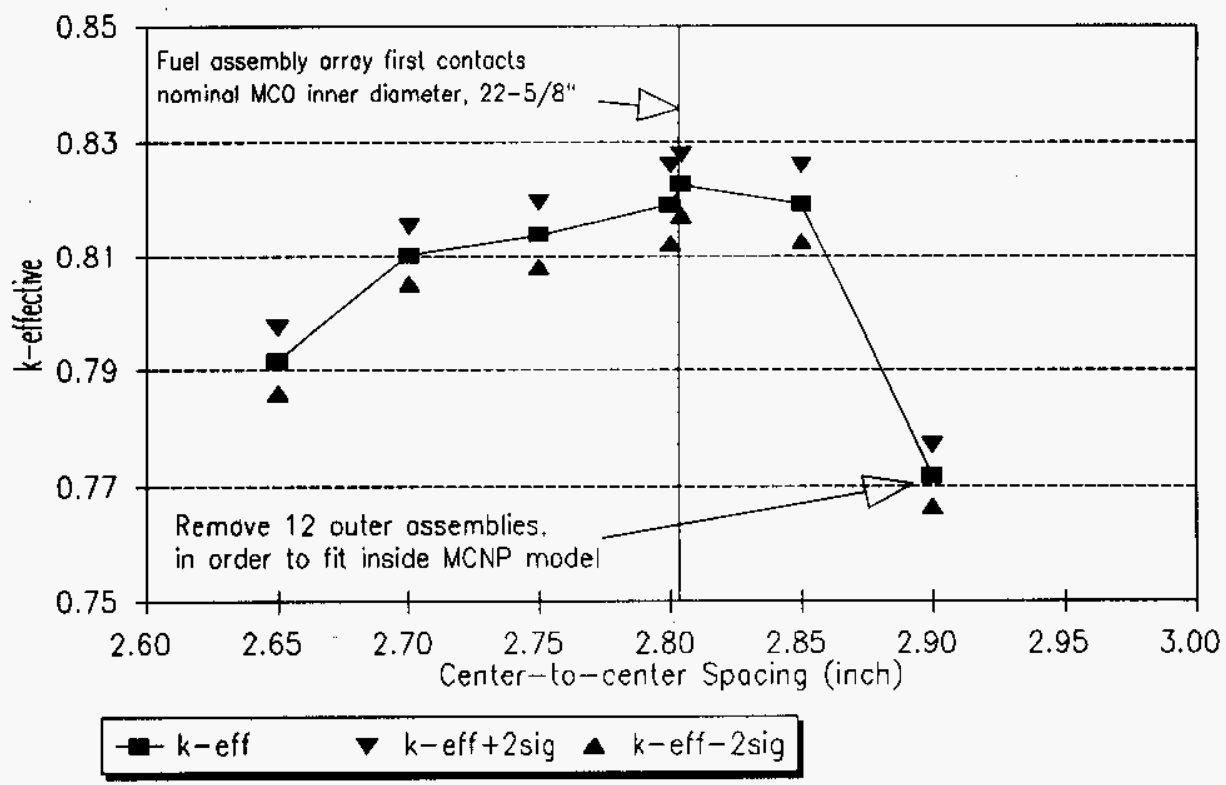

Note: The fuel assembly array first contacts the basket side at a lattice spacing of $2.8041 \mathrm{in}$. The $\mathrm{k}_{\mathrm{off}}$ for this spacing is 0.82268 with an uncertainty of 0.00264 and for a spacing of $2.80 \mathrm{in}$. when the $\mathrm{k}_{\mathrm{off}}$ is 0.81923 with an uncertainty of 0.00342 . 
Figure B-7. Uniform Change of Lattice Spacing for Mark IA Assemblies.

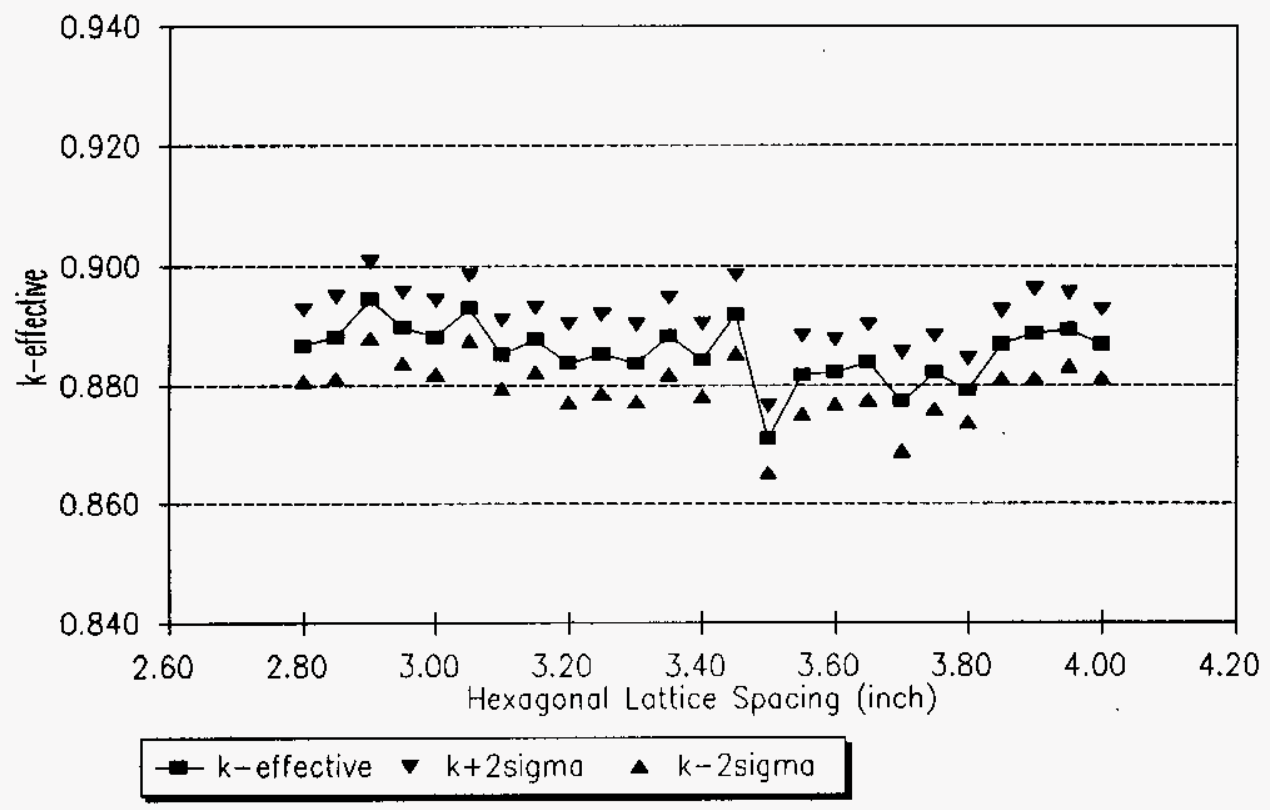

Figure B-8. Uniform Change of Lattice Spacing for Mark IV Assemblies.

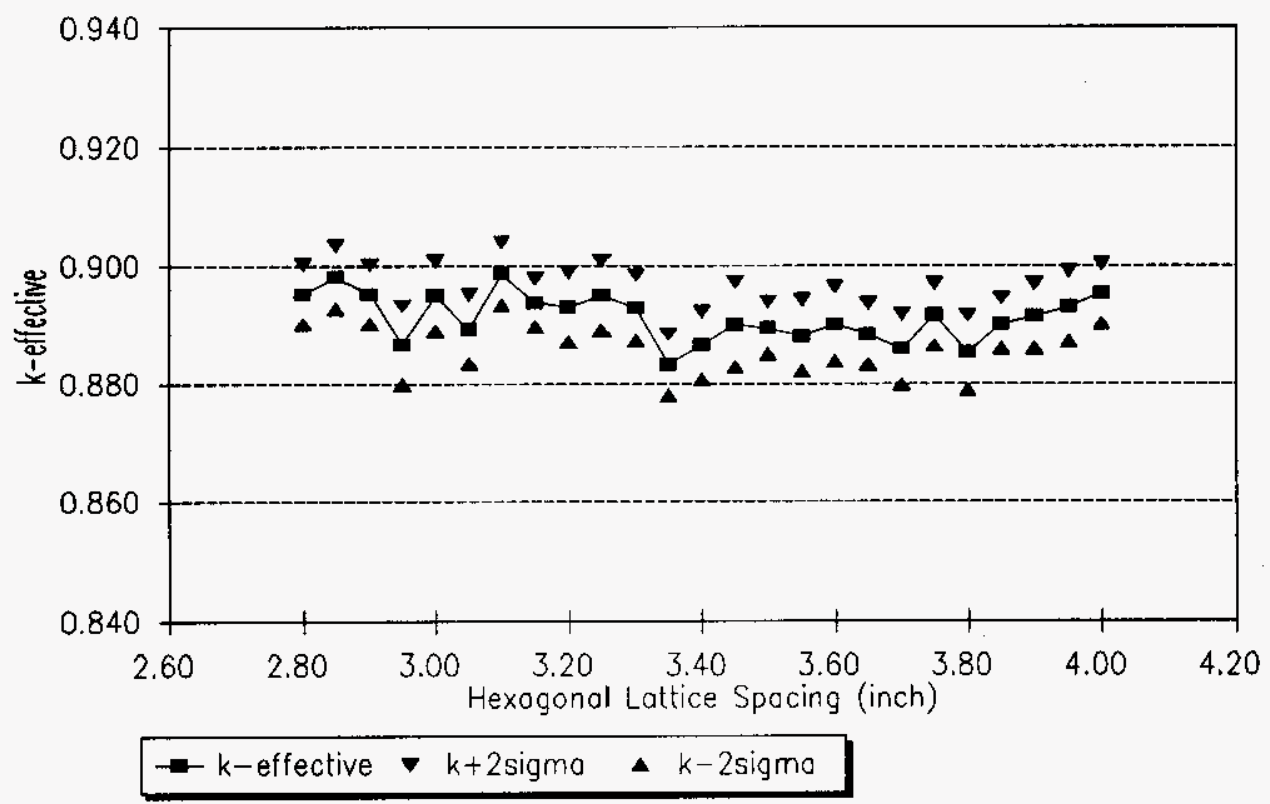


Figure B-9. Uniform Change of Lattice Spacing for Multi-Canister Overpacks Loaded with Mark IA Assemblies and no Scrap Baskets.

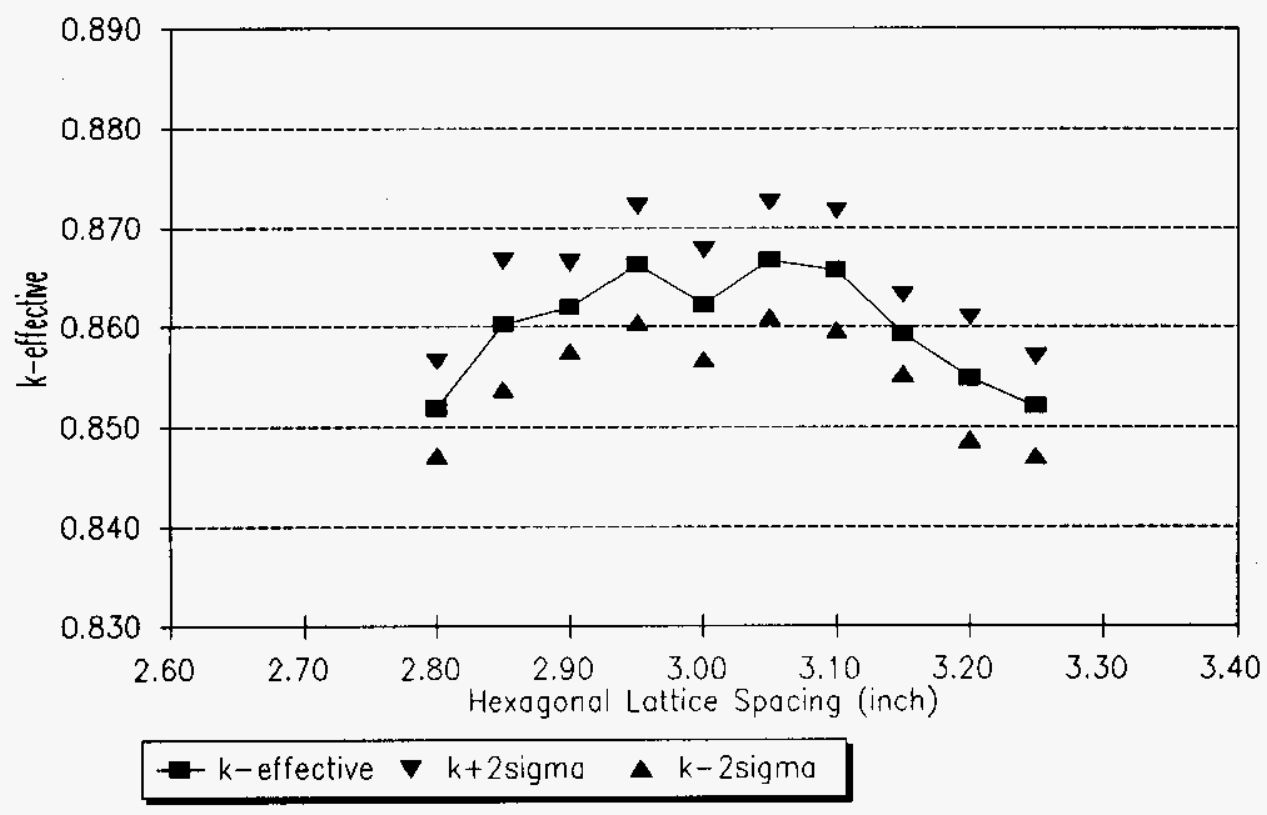

Figure B-10. Uniform Change of Lattice Spacing for Multi-Canister Overpacks Loaded with Mark IV Assemblies and no Scrap Baskets.

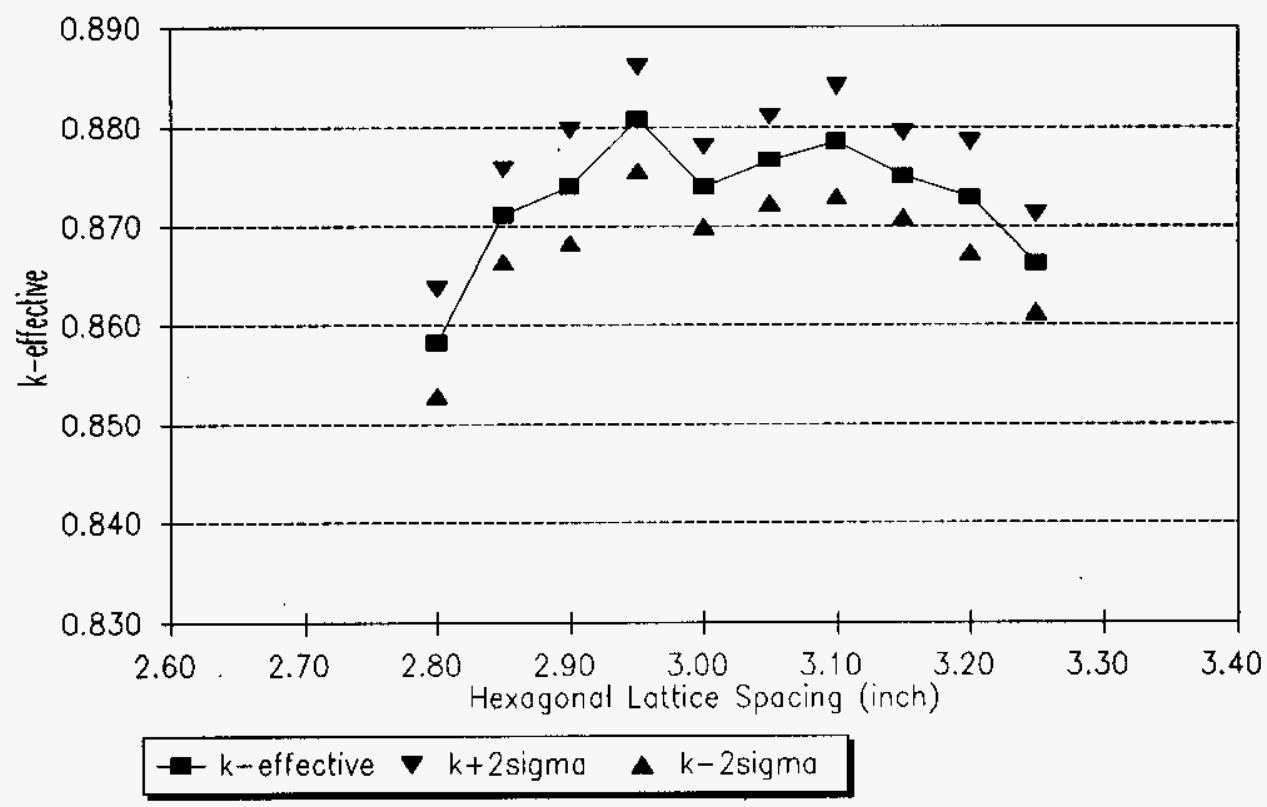


Figure B-11. Lattice k-Infinity and Temperature Coefficients for N Reactor Fuel Assemblies.

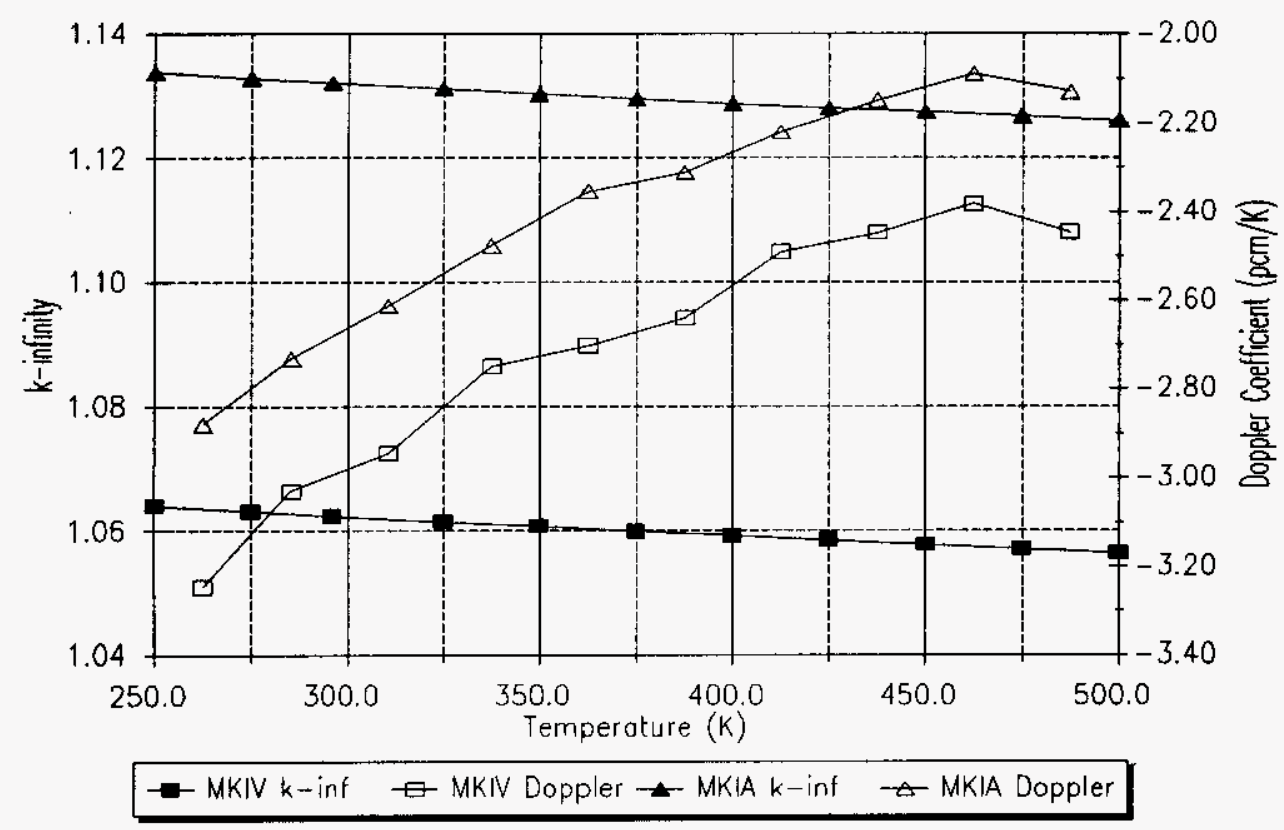


HNF-SD-SNF-CSER-005 REV 5

\section{APPENDIX C}

\section{ROD VERSUS SPHERICAL GEOMETRY}

FOR SCRAP OR RUBBLE MODEL 


\section{HNF-SD-SNF-CSER-005 REV 5}

This page intentionally left blank. 


\section{APPENDIX C}

\section{ROD VERSUS SPHERICAL GEOMETRY FOR SCRAP OR RUBBLE MODEL}

This appendix demonstrates that either spheres or cylinders can be used to find the maximum reactivity of scrap or rubble by optimizing the size and spacing of that shape. By inference, cylinders may then be used to find the maximum reactivity for either rubble or scrap. This demonstrates the applicability of treating a random arrangement of rubble or scrap as a pristine lattice of uranium rods in water. The question to be explored is whether an explicit spherical lattice optimizes to a higher $k_{\infty}$ than a cylindrical one. A comparison between an optimized array of spheres and cylinders was addressed with a series of calculations using a Monte Cario n-particle (MCNP) transport code (Breismeister 1993, Carter 1996) calculations, comparing a hexagonal pitch rod lattice with an explicit, three-dimensional, lattice unit based on spheres arranged in a face-centered-cubic geometry. The fissionable material assumed was uranium metal with an enrichment of $0.95 \mathrm{wt} \%{ }^{235} \mathrm{U}$. For both rods and spheres, a double parameter search was made to find the maximum $k_{\infty}$, as the spacing was varied, as a function of uranium chunk diameter.

Theoretically, the two most important parameters in a heterogeneous lattice cell problem are (1) the degree of self-shielding, and (2) the neutron spectrum, which depends on the degree of neutron moderation. The degree of self-shielding determines the difference between the flux inside and outside the fuel region. Neutrons are born above the ${ }^{238} \mathrm{U}$ resonances and are thermalized by the water to energies below the resonances allowing them to escape much of the ${ }^{238} \mathrm{U}$ resonance parasitic capture in low-enriched uranium metal systems. Lattice calculations of $k_{\infty}$ are greater for optimal heterogeneous systems because the thermalization of neutrons in the water region where there is an absence of strong absorbers (i.e., ${ }^{238} \mathrm{U}$ ) increases the resonance escape probability of neutrons returning into the fuel region. The degree of self-shielding is quantified in neutron transport theory using the concept of the mean chord length. The mean chord length, $\langle\mathrm{R}\rangle$, can be thought of as the average distance a neutron travels through a material region. A simple formula for calculating the mean chord length (Duderstadt and Hamilton 1976) is $<\mathrm{R}>=4 \times$ (volume/area). For a rod, this becomes

$$
\begin{aligned}
<R> & =\frac{4\left(\pi R^{2} L\right)}{2 \pi R L} \quad \text { for a cylinder of length } L \\
& =2 R \\
& =D
\end{aligned}
$$


For a spherical lattice, this becomes

$$
\begin{aligned}
\langle R> & =\frac{4\left(\frac{4}{3} \pi R^{3}\right)}{4 \pi R^{2}} \\
& =\frac{4}{3} R \quad \text { for a sphere } \\
& =\frac{2}{3} D
\end{aligned}
$$

The mean chord length must be the same for the degree of self-shielding to be the same between cylindrical and spherical lattices. This occurs when the diameter of the cylinder is equal to two-thirds of the diameter of the equivalent sphere. Figure C-1 presents the results of the MCNP calculations. Each MCNP $\mathrm{k}_{\text {eff }}$ shown in Figure C-1 is a maximum value, out of ten MCNP calculations that varied the spacing between either the rods or spheres. As expected, the shapes of the two curves are different, but the lattice $\mathrm{k}_{\infty}$ that the two curves maximized themselves to is essentially the same (well within the $2 \sigma$ error of the calculation). The maximum $k_{\infty}$ for the cylinder lattice is $1.09082 \pm 0.00265$, and the maximum $k_{\infty}$ for the spherical lattice is 1.09189 \pm 0.00247 . Finally, the sphere diameter that produces the maximum is about 1.5 times the diameter that produces a maximum for the rods, as predicted by theory.

The foregoing discussion was intended to establish that treating random, irregularly shaped scrap or rubble as either rods or spheres should make no difference in the calculated value of the maximum reactivity of the material. Experimental evidence exists that supports the assertion that a random arrangement of pieces of fissile material will have a lower reactivity than a uniform lattice of the same size pieces, even if the average moderator-to-fuel volume ratio is the same as for the uniform lattice (Lloyd 1957, Lloyd 1958). This provides another layer of conservatism inherent in the way scrap and rubble calculations have been performed for inclusion in this criticality safety evaluation report.

The rod and sphere comparison is in excellent agreement with certain transport theory predictions, and hence greater confidence may be put in the assumption that the primary factors that have significance in determining unit lattice reactivity are the mean (or effective) chord length and the degree of moderation. These factors are not sensitive to the spatial details of the lattice geometry. Therefore, treating scrap material using parametric calculational results obtained from a cylindrical lattice calculation is valid.

\section{REFERENCES}

Breismeister, J. F., Editor, 1993, MCNP - A General Monte Carlo N-Particle Transport Code, Version 4A, LA-12625, Los Alamos National Laboratory, Los Alamos, New Mexico. 


\section{HNF-SD-SNF-CSER-005 REV 5}

Carter, L. L., 1996, Certification of MCNP Version $4 A$ for WHC Computer Platforms, WHC-SD-MP-SWD-30001, Rev. 8, Westinghouse Hanford Company, Richland, Washington.

Duderstadt, J. J., and L. J. Hamilton, 1976, Nuclear Reactor Analysis, pp. 432 - 435, John Wiley \& Sons, Inc., New York, New York.

Lloyd, R. C., 1957, Buckling Measurements of Fuel Elements in a Random Array, Water Moderated, Nuclear Physics Quarterly Report, HW-54591,35.

Lloyd, R. C., 1958, Buckling Measurements of Fuel Elements in a Random Array, Water Moderated, Nuclear Physics Quarterly Report, HW-54879,12. 
Figure C-1. Maximum k-Infinity Versus Outer Diameter for Face-Centered-Cubic Spherical Lattices and for Hexagonal Rod Lattices.

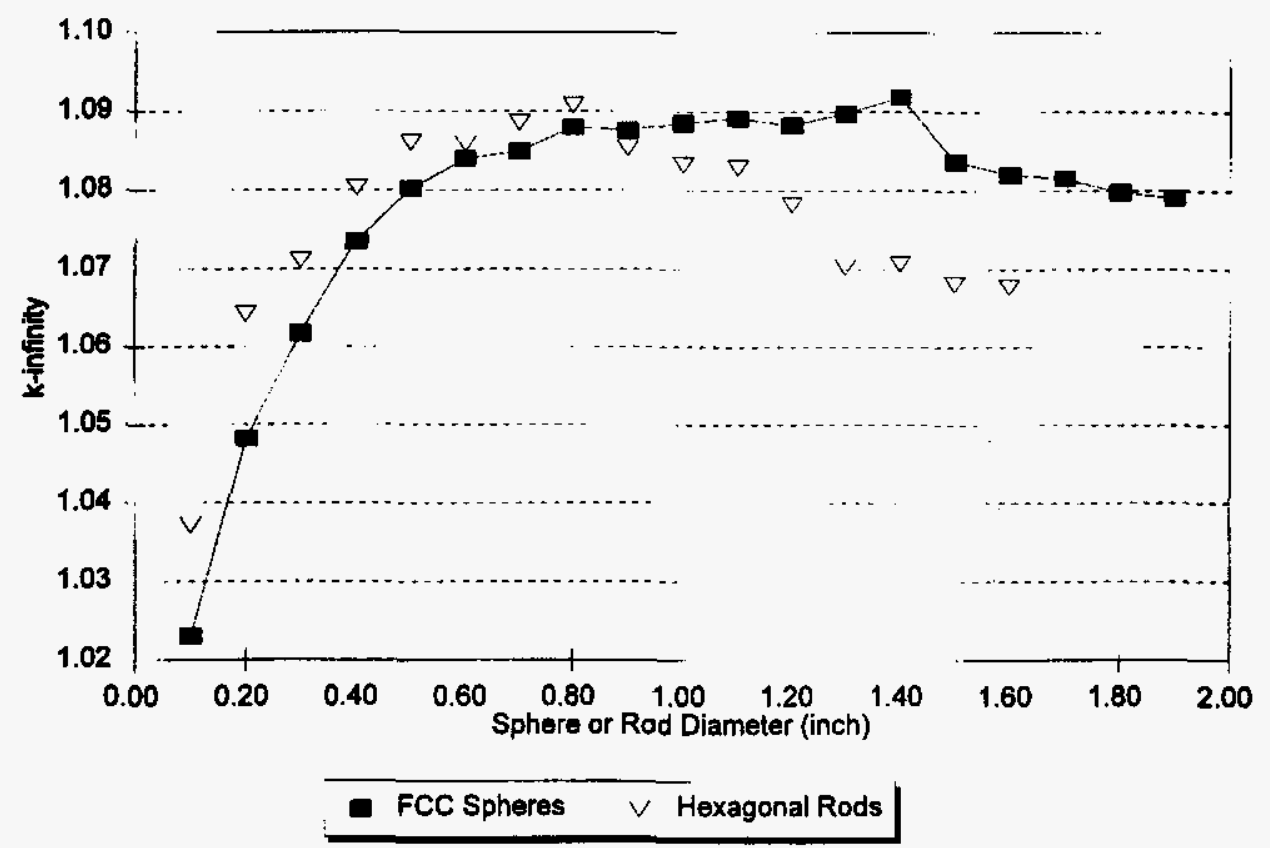


HNF-SD-SNF-CSER-005 REV 5

APPENDIX D

BURNUP EFFECTS ON N REACTOR MARK IV AND MARK IA FUEL 
HNF-SD-SNF-CSER-005 REV 5

This page intentionally left blank. 


\section{APPENDIX D}

\section{BURNUP EFFECTS ON N REACTOR MARK IV AND MARK IA FUEL}

All calculations in this criticality safety evaluation report were based on unirradiated fuel. Fuel burnup credit would provide an additional safety margin. Experimental data exist for Mark IA fuel showing the impact of fuel burnup on nuclear criticality safety parameters. Burnup calculations have been performed for both Mark IV and Mark IA fuel types, using hot operating conditions in the N Reactor lattice.

Figure D-1 shows the reactor lattice $k_{\infty}$ for both Mark IV and Mark IA fuel. The initial drop in reactivity is due to the buildup of equilibrium xenon poisoning. The subsequent behavior of Mark IA fuel shows that reactivity decreases monotonically with exposure. Mark IV fuel, because of its lower initial enrichment, shows an increase in reactivity because of the buildup of ${ }^{239} \mathrm{Pu}$. This behavior has been shown in previous analyses using the HAMMER lattice code (Toffer 1975). The minimum spherical critical mass for unirradiated Mark IA fuel is $1,893 \mathrm{~kg}$. This calculation assumes optimal moderation (hexagonal lattice spacing of 3.1 in. center-tocenter) and full water reflection. With burnup equal to 92 days, which corresponds to $6 \mathrm{wt} \%$ ${ }^{240} \mathrm{Pu}$ in total plutonium, this minimum critical mass increases to $2,419 \mathrm{~kg}$ - an increase of $28 \%$. With burnup equal to 162 days, which corresponds to $9 \mathrm{wt} \%{ }^{240} \mathrm{Pu}$ in total plutonium, this critical mass increases to $2,946 \mathrm{~kg}$ - an increase of $56 \%$ over the unirradiated value. These results are consistent with earlier work (Toffer 1975, Figure 11).

Burnup effects were calculated assuming the isotopic concentrations present at each of the exposure points. Because of its short half-life, ${ }^{135} \mathrm{Xe}$ was eliminated. Figure D-2 shows the variation in calculated lattice $k_{\infty}$ as the spacing in cold water is varied. Figure D-3 shows the corresponding spherical critical mass. As shown in Figures D-2 and D-3, taking credit for burnup to $6 \mathrm{wt} \%{ }^{240} \mathrm{Pu}$ for Mark IA fuel gives approximately $20 \mathrm{mk}$ in reactivity and a $28 \%$ increase in the minimum critical mass. Figures D-4 and D-5 illustrate these same results for the less reactive Mark IV fuel.

The variations in maximum lattice $k_{\infty}$ and minimum critical mass are plotted as functions of exposure in Figures D-6 and D-7. In Figure D-7, this evolution is plotted as the minimum critical mass, as exposure increases, divided by the minimum critical mass with no exposure. Figure D-7 may be compared directly with Figure 11 in DUN-7824 (Toffer 1975). The new and the old figures are in reasonably good agreement, but the results shown Figure D-7 were for lower burnup than those shown in DUN-7824 (Toffer 1975). As before, burnup effects were treated by using the isotopics generated with the WIMS-E lattice code (Gubbins et al. 1982) for the hot operating lattice environment of $\mathrm{N}$ Reactor. These isotopics (except for ${ }^{135} \mathrm{Xe}$, which was set to zero) were then used in a cold water lattice model, in which the spacing between fuel assemblies was adjusted to find maximum $\mathrm{k}_{\infty}$ and minimum critical mass. The first points plotted in Figures D-6 and D-7 are for 2 days. The point plotted in Figure D-7 at zero exposure would be exactly equal to 1.0 . 
There is a significant difference between Figures D-1 and D-6. Figure D-1 shows the change in $\mathbf{k}_{\infty}$ inside the fixed graphite lattice of the $\mathrm{N}$ Reactor, using hot operating conditions. These are the $\mathbf{k}_{\infty}$ values produced by WIMS-E as the burnup calculation proceeds. Figure D-6 shows the maximum $\mathrm{k}_{\infty}$ when the fuel is removed from the reactor, ${ }^{135} \mathrm{Xe}$ is allowed to decay away, and the fuel is immersed and optimally spaced in a light water moderator. The relative shapes of the two curves in Figures D-1 and D-6 are quite similar. Results presented in Figures D-1 through D-7 were generated with the old ' 1986 ' WIMS-E cross section library.

Figure D-8 illustrates the long-term behavior of the maximum lattice $\mathbf{k}_{\infty}$ in cold water as the fuel is allowed to decay over a 100 -year period. This latest burnup evaluation was performed with the new '1994' WIMS-E cross section library, which includes improved treatment of the transuranic burnup chains up through curium. Transuranic isotopic predictions obtained from this new library have been compared to measured $N$ Reactor data (Schwinkendorf et al. 1996). Excellent agreement with measured data is shown for all transuranic isotopes compared. The results indicate a slight reduction in reactivity for both Mark IV and Mark IA fuel as both the fission products and transuranic chains decay. Fission products eventually decay into other isotopes that provide neutron absorption. Figure D-9 depicts only the Mark IV curve shown in Figure D-8, with an expanded vertical scale so that the decrease in reactivity is more easily seen. This curve is, of course, the net result of many isotopes changing simultaneously, but it is worth noting that it closely correlates to the ${ }^{241} \mathrm{Pu}$ half-life of 14.4 years $\left({ }^{241} \mathrm{Pu}\right.$ is fissile and contributes to the reactivity of the system). Figures D-6 and D-8 are similar but are on different time scales and use different WIMS-E cross section libraries.

\section{REFERENCES}

Gubbins, M. E., M. J. Roth, and C. J. Taubman, 1982, A General Introduction to the Use of the WMS-E Modular Program, AEEW-R 1329, Reactor Physics Division, AEE Winfrith, England.

Toffer, H., 1975, Criticality Safety Analysis Report, Subcritical Measurements in the Hanford N Reactor Fuel Storage Basin, DUN-7824, Add. 1, Douglas United Nuclear, Richland, Washington.

Schwinkendorf, K. N., S. P. Roblyer, and S. A. Parra, 1996, Use of the WIMS-E Lattice Code for Prediction of the Transuranic Source Term for Spent Fuel Dose Estimation, the SPECTRUM 96 International Topical Meeting on Nuclear and Hazardous Waste Management, Seattle, Washington, August 18-23, 1996, Vol. 1, pp. 709-713. 
Figure D-1. k-Infinity versus Exposure for N Reactor Hot Operating Conditions.

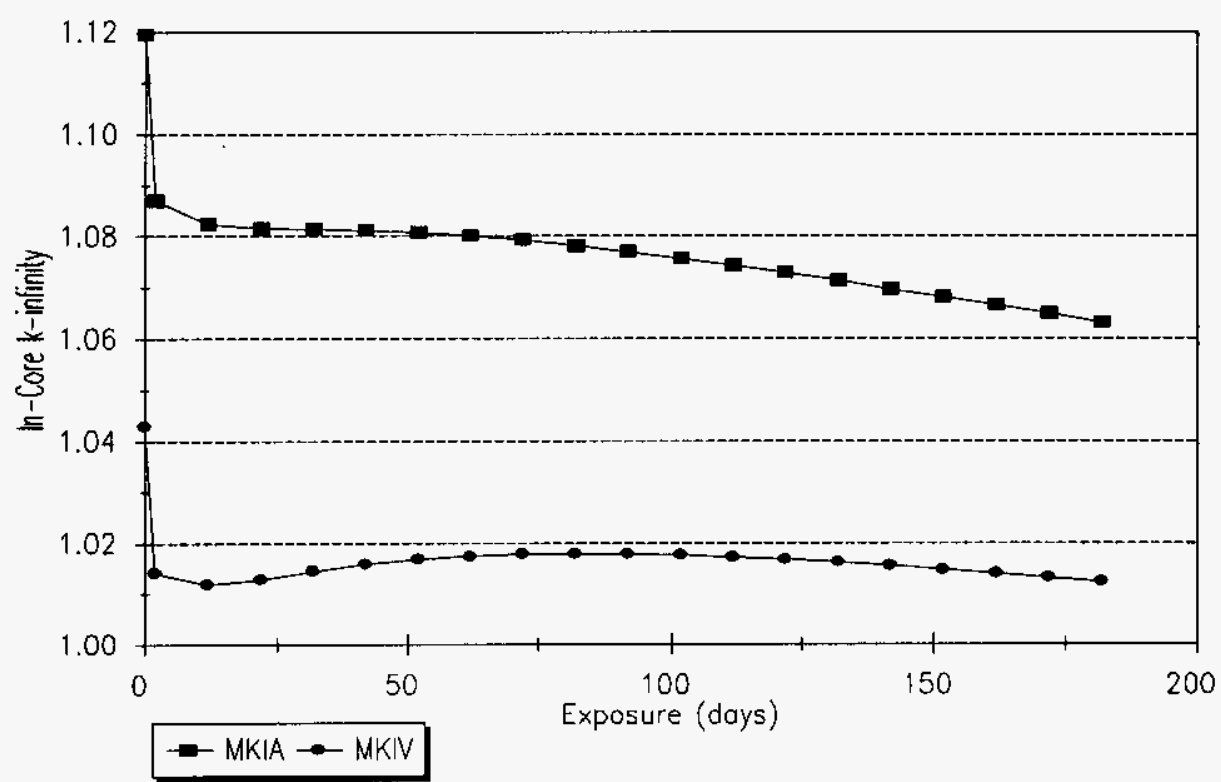

Figure D-2. k-Infinity versus Hexagonal Lattice Spacing for Mark IA Assemblies in Cold Water.

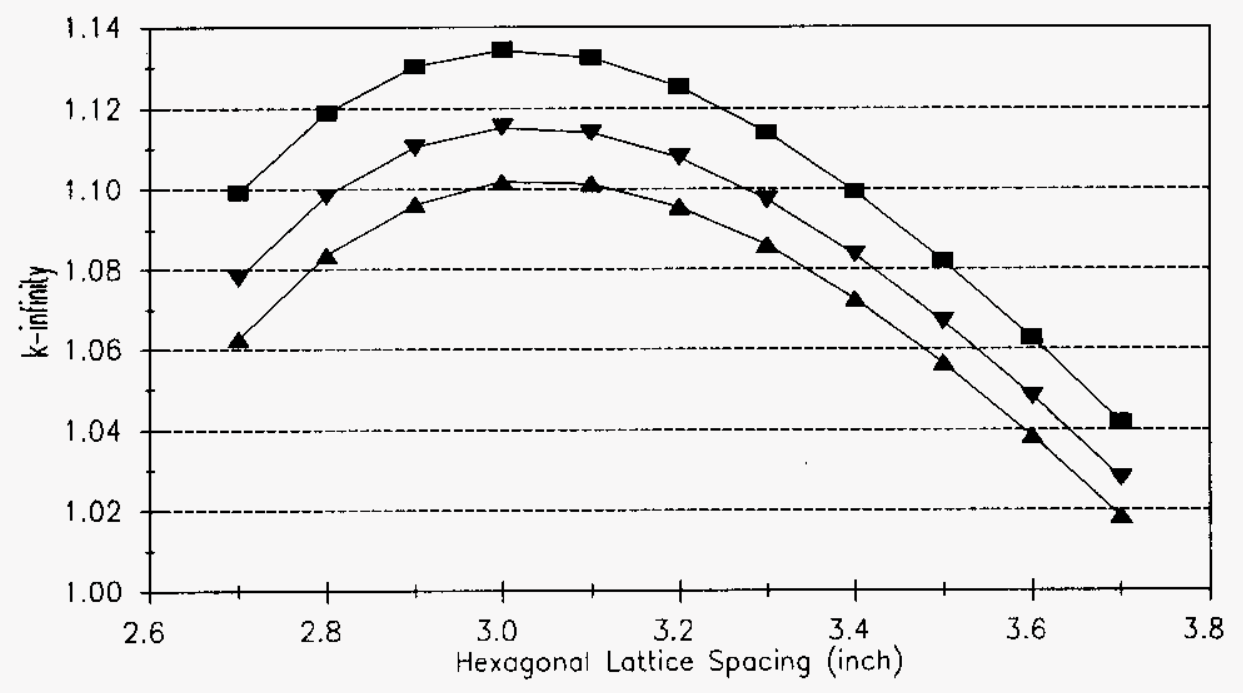


Figure D-3. Critical Mass versus Lattice Spacing for Mark IA Assemblies in Cold Water.

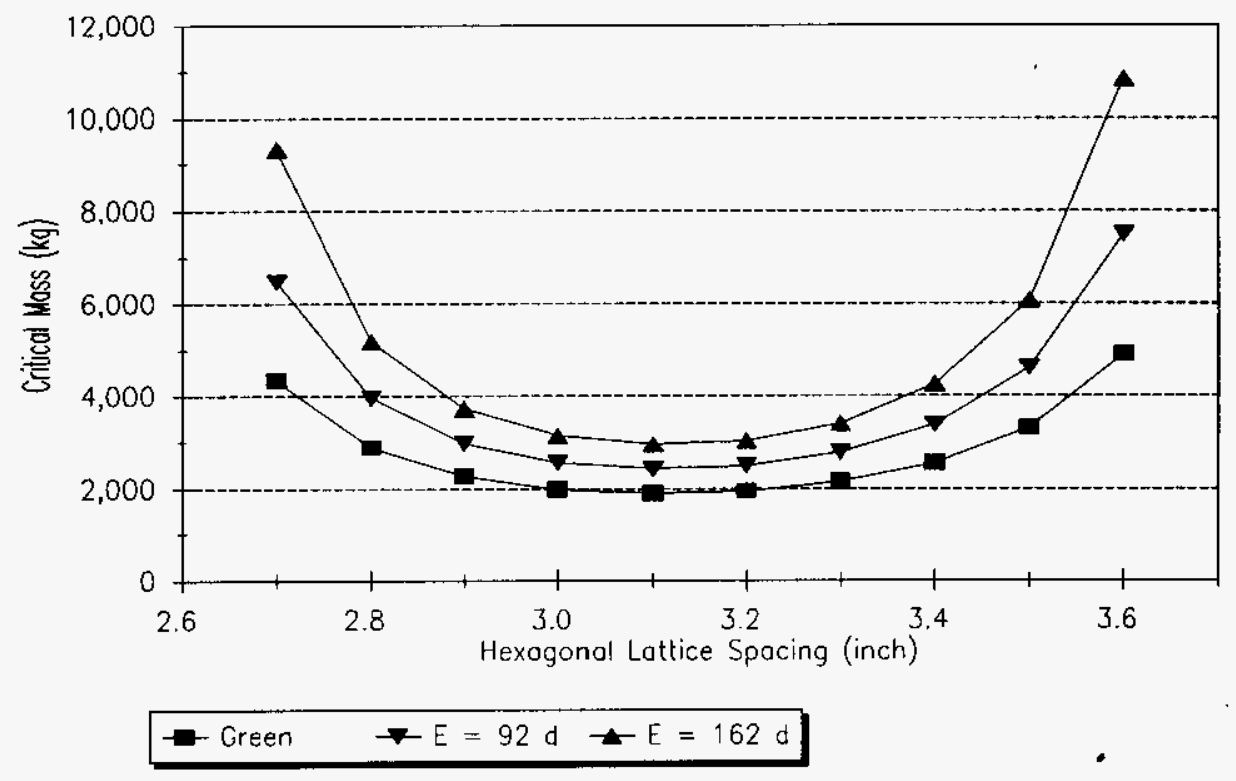

Figure D-4. k-Infinity versus Hexagonal Lattice Spacing for Mark IV Assemblies in Cold Water.

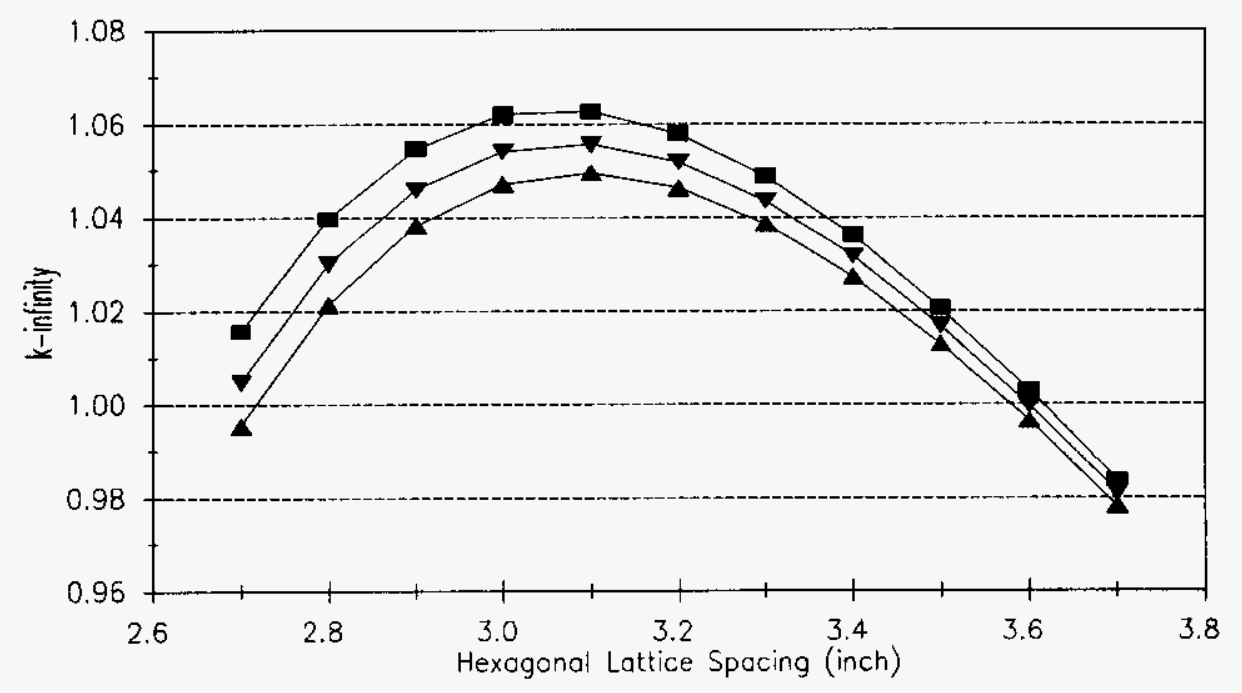


Figure D-5. Critical Mass versus Lattice Spacing for Mark IV Assemblies in Cold Water.

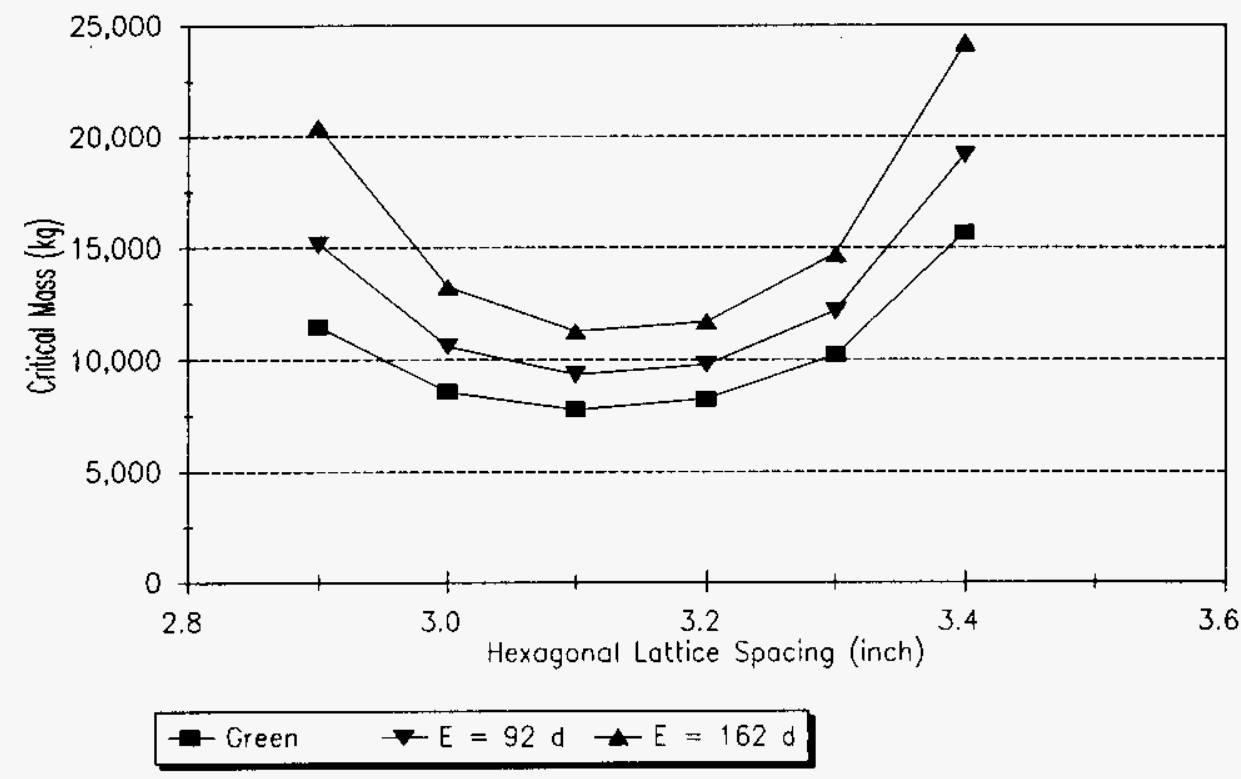

Figure D-6. Maximum Lattice k-Infinity versus Exposure for $\mathrm{N}$ Reactor Fuel in Cold Water.

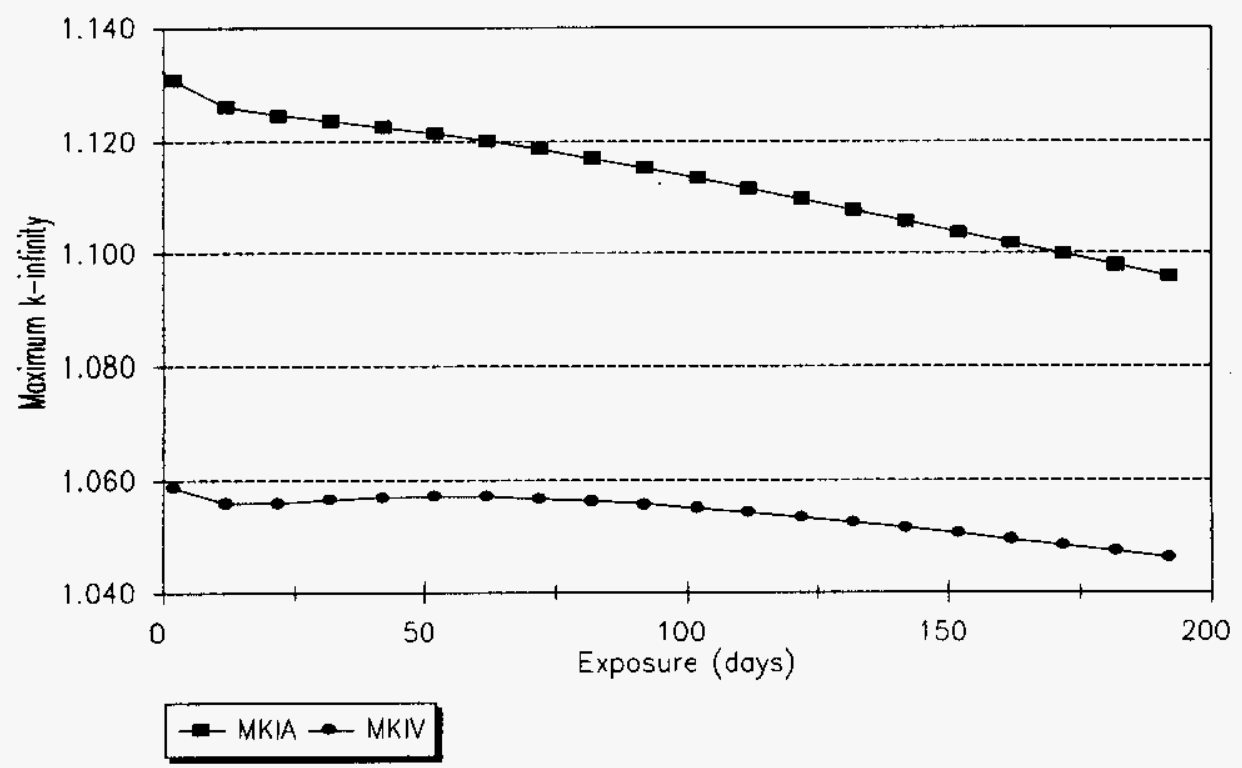


Figure D-7. Minimum Critical Mass Ratio versus Exposure for N Reactor Fuel in Cold Water.

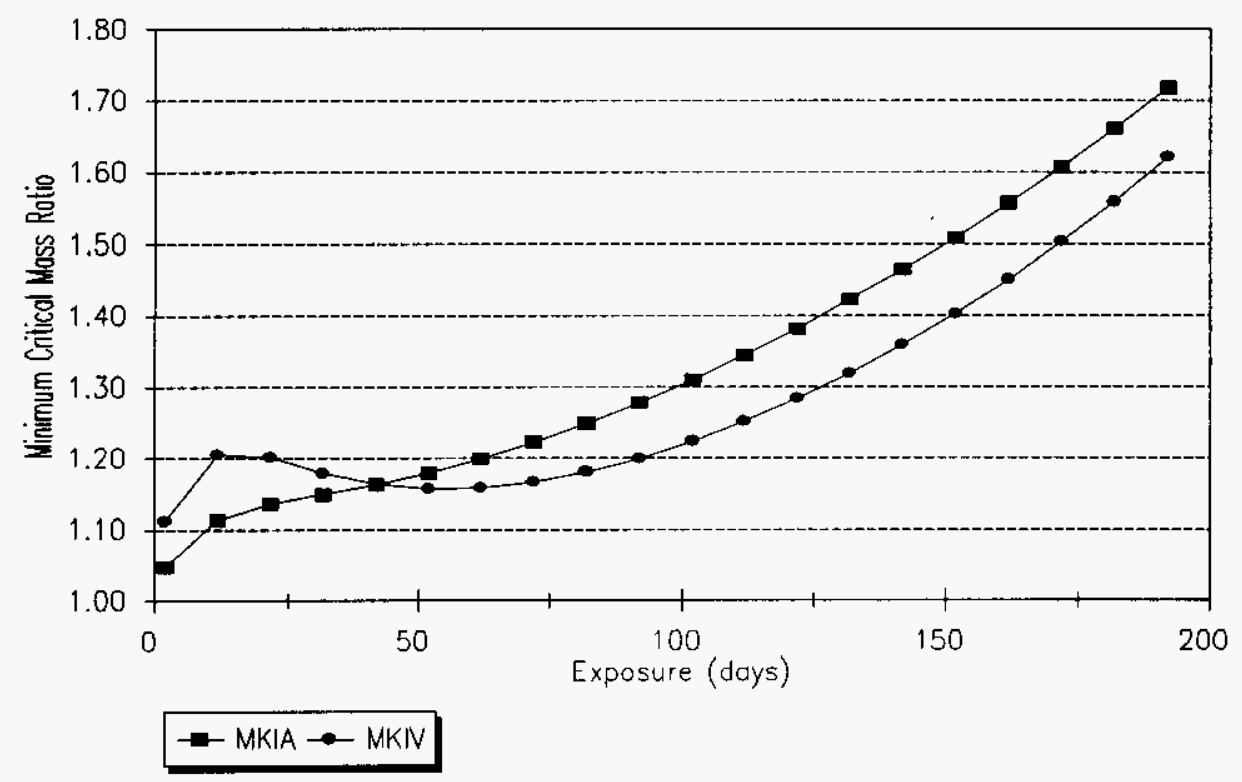

Figure D-8. Maximum Lattice k-Infinity versus One Hundred-Year Decay for N Reactor Fuel.

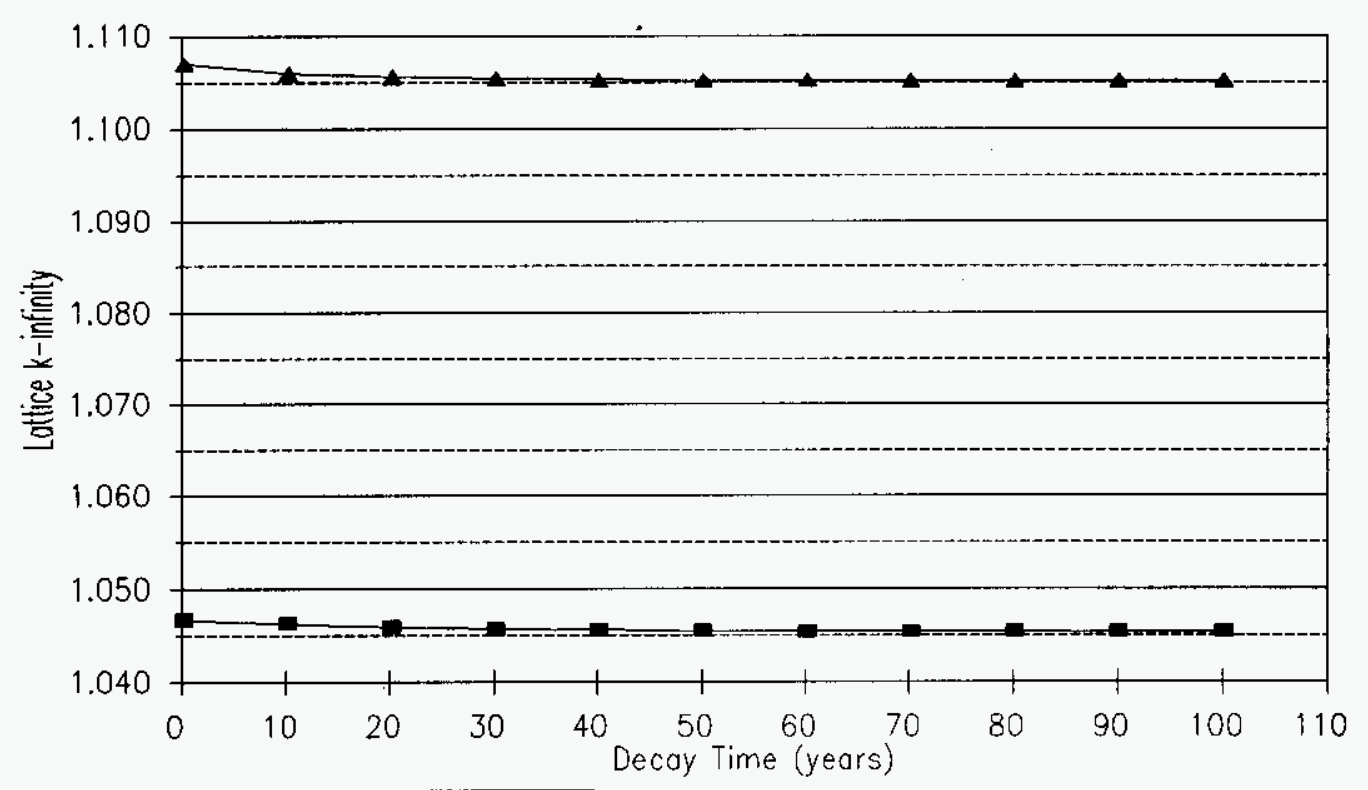

- Mork IV $\rightarrow$ Mark IA 
HNF-SD-SNF-CSER-005 REV 5

Figure D-9. Maximum Lattice k-Infinity versus One Hundred Year Decay for N Reactor Mark IV Fuel.

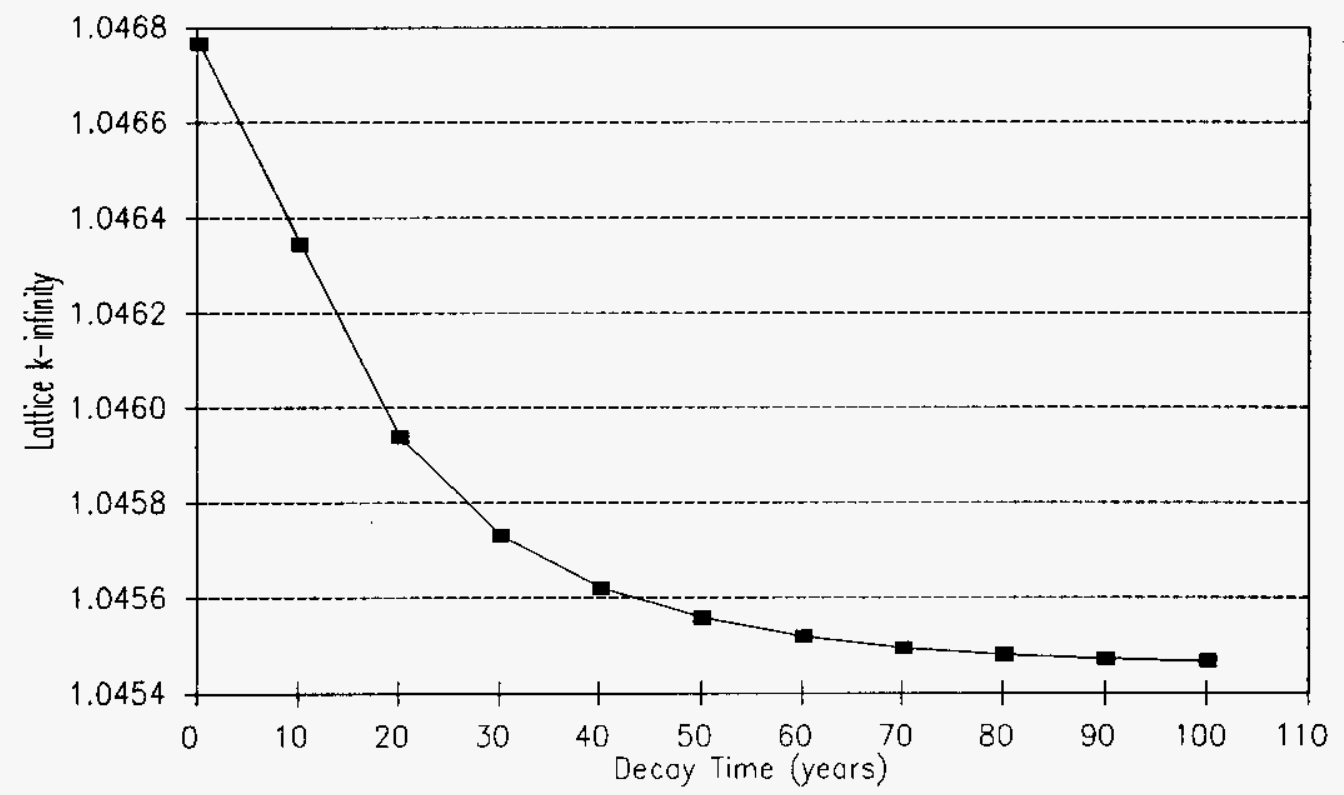


HNF-SD-SNF-CSER-005 REV 5

This page intentionally left blank. 
HNF-SD-SNF-CSER-005 REV 5

\section{APPENDIX E}

RADIAL ISOTOPIC PROFILE EVOLUTION DURING BURNUP 


\section{HNF-SD-SNF-CSER-005 REV 5}

This page intentionally left blank. 


\section{APPENDIX E}

\section{RADIAL ISOTOPIC PROFILE EVOLUTION DURING BURNUP}

Uranium and transuranic isotope buildup in nuclear reactor fuel is a function of both the flux and the neutron spectrum. In a heterogeneous reactor lattice, neutrons born from fission in the fuel will escape into the moderator, where they will undergo collisions with the hydrogen in the water molecules and lose energy in the process (i.e., they will become moderated). For low-enriched uranium metal fuel, a heterogeneous lattice will increase reactivity by increasing the probability that a neutron will moderate to thermal energies without being absorbed by one of the many resonances in ${ }^{238} \mathrm{U}$. This probability is increased by allowing the high energy neutrons to thermalize in the absence of resonance absorbers.

Spatial self-shielding in heterogeneous lattices will produce spatial flux gradients, and the fluxes will have different shapes for different energy ranges throughout the spectrum; the fast, or high energy, flux will have a different spatial shape than will the thermal, or lower energy, neutron flux. This shape function will drive the isotopic burnup equations differently as the radial position within the fuel piece changes. In addition, different nuclear reactions occur at different energies. For example, the depletion of ${ }^{235} \mathrm{U}$ occurs when it absorbs a neutron and either fissions $(80 \%$ of the time) or emits a gamma ray. The absorption of neutrons in ${ }^{235} \mathrm{U}$ is much greater for thermal neutron energies because of the " $1 / \mathrm{v}$ behavior" of the absorption cross section. The depletion reaction of ${ }^{235} \mathrm{U}$ is therefore maximized where the thermal neutron flux is maximized. In contrast, the buildup of ${ }^{239} \mathrm{Pu}$ is an indirect result of the absorption of a neutron in ${ }^{238} \mathrm{U}$. When ${ }^{238} \mathrm{U}$ absorbs a neutron, it is transmuted into ${ }^{239} \mathrm{U}$, which emits a beta particle to become ${ }^{239} \mathrm{~Np}$, which emits another beta particle to become ${ }^{239} \mathrm{Pu}$. These beta decays are not a function of the local flux spectra, but the neutron absorption in ${ }^{238} \mathrm{U}$ is. Significant neutron absorption in ${ }^{238} \mathrm{U}$ occurs in the epithermal or resonance range of the spectrum. Plutonium production is therefore expected to be greater where higher-than-thermal neutron energies are maximized.

The early Hanford Site weapons material production reactors (also called single pass reactors [SPRs] because of their lack of a closed primary coolant loop) used both solid (or "slug") uranium metal rods and annular tubes for fuel. The annular tube fuel designs were used in later years because the central coolant region allowed the reactors to operate at higher power. $\mathrm{N}$ Reactor used a double tube-in-tube fuel assembly design. Various computer design tools have evolved over the years to analyze the performance of these fuel types, including the DCODE code. The DCODE computer code produced the same engineering results for fuel assemblies of the N Reactor design. DCODE also performed neutronics calculations (which determine the power sharing fractions of inner and outer elements) based on an analytical solution to the four-group $P_{3}$ equations.

More modern reactor analysis codes exist for performing these neutronics calculations, such as the British WIMS-E code (Gubbins et al. 1982), which will perform 69-group integral transport theory calculations for any user-defined annular problem geometry. The isotopic burnup chains in WIMS-E are also more detailed than those treated in DCODE. This appendix 
presents the results of WIMS-E calculations of the isotopic burnup profiles inside both SPR and N Reactor fuel. Only the annular fuel type (also called the "I\&E" fuel) was evaluated for the SPRs, but both Mark IV and Mark IA N Reactor fuel types were evaluated.

Most of the SPR I\&E fuel was composed of natural uranium metal. Both the inner and outer elements of the $\mathrm{N}$ Reactor Mark IV fuel contained $0.947 \mathrm{wt} \%$ enriched uranium metal. The Mark IA fuel used a $0.947 \mathrm{wt} \%$ inner and a $1.249 \mathrm{wt} \%$ enriched outer tube. The Mark IA fuel, because of its higher reactivity, was used as "spike" fuel to reduce radial peaking factors in the reactor.

For the SPR I\&E fuel, hot operating conditions were obtained from archived hardcopy printouts (WIMS-E does not perform heat transport calculations, only reactor physics [Gubbins et al. 1982]). These hot operating conditions were used as input for the material and geometry descriptions for WIMS-E. Hot operating conditions for the N Reactor fuel lattices were obtained from old DCODE results. WIMS-E performed the burnup analysis assuming 20 radial subdivisions in the annular fuel regions; the burnup equations were driven locally for each of the radial intervals by the 69-group neutron flux and spectrum for that particular radial interval. Figure E-1 illustrates the ${ }^{235} \mathrm{U}$ depletion as burnup progresses. Figure E-2 presents the ${ }^{239} \mathrm{Pu}$ buildup. Figure E-3 presents the sum of the two profiles, and is intended to be representative of a "total fissile" profile. Higher fissile transuranics (such as ${ }^{241} \mathrm{Pu}$ ) are generated from the WIMS-E burnup chains, but these are not included in Figure E-3. Note the scale in Figure E-3. Even though plutonium buildup is enhanced at the outer periphery of the fuel, fissile uranium depletion partially compensates for this effect. For higher-exposure plutonium, the ${ }^{240} \mathrm{Pu}$ content, which is a thermal-spectrum neutron poison, also increases, as shown in Figure E-4. Figures E-5 through E-8 illustrate the same results for Mark IV fuel from N Reactor, and Figures E-9 through E-12 present the Mark IA results.

The enhancement of plutonium production at the outer periphery of nuclear fuel is documented in the commercial industry (Carlsen and Sah 1980); computer code predictions also are documented (Palmer et al. 1982). In addition to radial profiles generated during irradiation because of neutronic effects, thermochemical migration and vapor transport effects have been considered in mixed oxide fuel (Olander 1976). Because of the co-extrusion process of fuels fabrication of Hanford Site production reactor fuel, the fuel is in intimate contact with the cladding (unlike commercial fuel where there is a fuel-cladding gap). Formation of intermetallic phases of plutonium and cladding, near the fuel-cladding interface, have been suggested as possible concentrating mechanisms for plutonium in Hanford Site production reactors. However, the conclusion has been that formation of intermetallics of this type would not have taken place because of the lower operating temperatures of the fuel. Results reported in this appendix consider only the neutronic factors driving the evolution of radial plutonium profiles.

The N Reactor burnup results indicate a more pronounced ${ }^{239} \mathrm{Pu}$ buildup effect near the outer surfaces of the fuel than do the SPR fuel burnup results. In all cases, there were 20 mesh intervals in the fuel regions. The SPR reactor fuel had thicker fuel annuli; therefore the mesh intervals were also larger. If the SPR burnup calculations had been performed using more radial mesh intervals, the radial plutonium production probably would have more enhancement near the 
fuel surface, just like the $\mathrm{N}$ Reactor results. The $\mathrm{N}$ Reactor results are likely as pronounced as they will get. These profiles look very much like the profiles in Palmer et al. (1982). Palmer et al. (1982) compared two independent codes (WIMS-E and RADAR) for the calculation of these profiles.

In all burnup calculations reported in this appendix, the production of plutonium is enhanced at the outer surfaces of the fuel; there is increased exposure near the surfaces because of self-shielding. However, this effect is at least partially mitigated by the fact that enhanced fissile uranium depletion also occurs near the fuel surfaces. In addition, the increased plutonium production near the surface also has a higher ${ }^{240} \mathrm{Pu}$ content, again, because of the increased exposure at the surface. The number of neutrons produced per fission is higher for ${ }^{239} \mathrm{Pu}$ than for ${ }^{233} \mathrm{U}$, so the plutonium is worth more than the fissile uranium, but this effect is not large. Scrap material composed of the outer skin of the fuel is more reactive than the average fuel, but not to a significant degree.

\section{REFERENCES}

Carlsen, H. and D. N. Sah, 1981, Radial Concentration and Effect on Temperature of Plutonium Formed in $\mathrm{UO}_{2}$ During Irradiation, DK-4000, Risø National Laboratory, Metallurgy Department, Roskilde, Denmark.

Gubbins, M. E., M. J. Roth, and C. J. Taubman, 1982, A General Introduction to the Use of the WIMS-E Modular Program, AEEW-R 1329, Reactor Physics Division, AEE Winfrith, England.

Olander, D. R. 1976, Fundamental Aspects of Nuclear Reactor Fuel Elements, TID-26711-P1, Technical Information Center, Energy Research and Development Administration, reprinted by U.S. Department of Energy, pp. 166-169.

Palmer, I. D., K. W. Hesketh, and P. A. Jackson, 1982, A Model for Predicting the Radial Power Profile in a Fuel Pin, British Nuclear Fuels Ltd., Springfields Works, Salwick, Preston, United Kingdom. 
Figure E-1. Evolution of the Uranium-235 Radial Profile for Annular K Reactor Fuel.

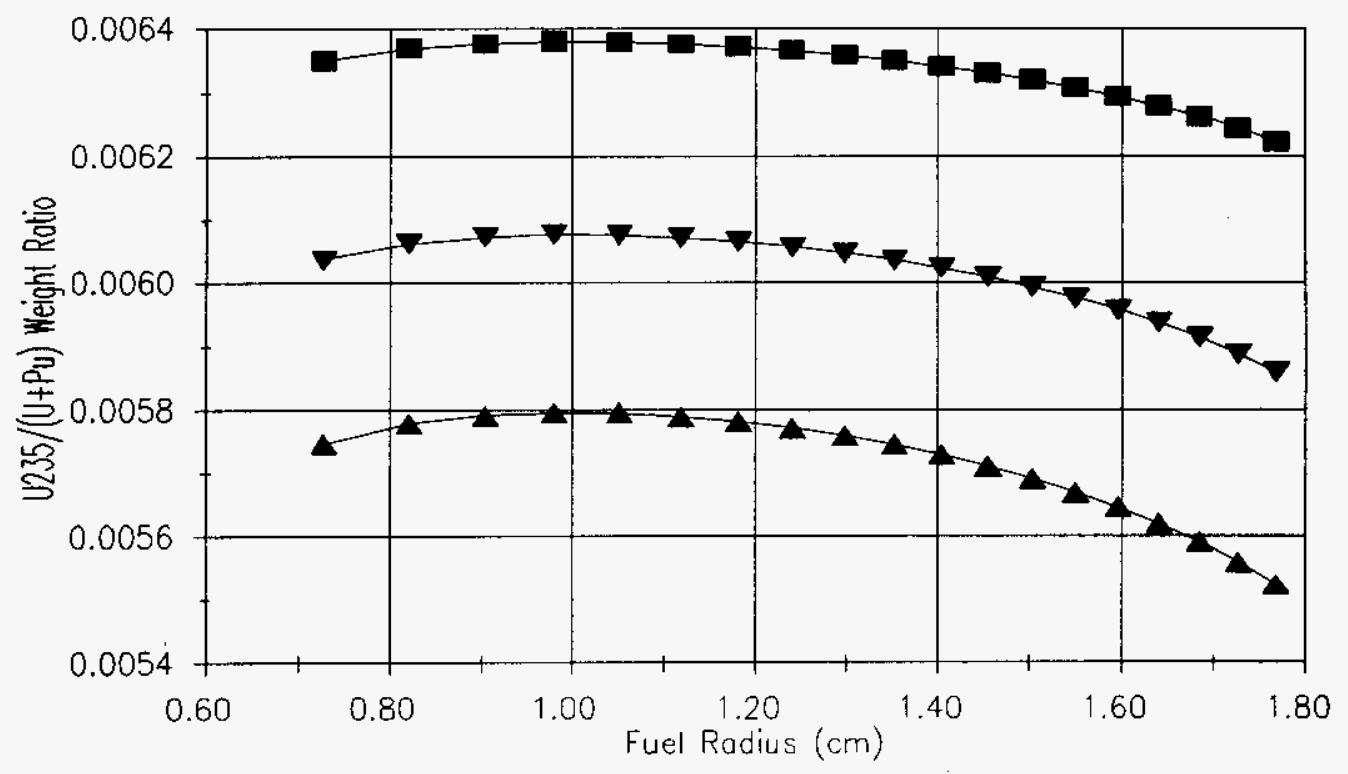

62 Days $\rightarrow 92$ Days $\leftarrow 122$ Days

Figure E-2. Evolution of the Plutonium-239 Radial Profile for Annular K Reactor Fuel.

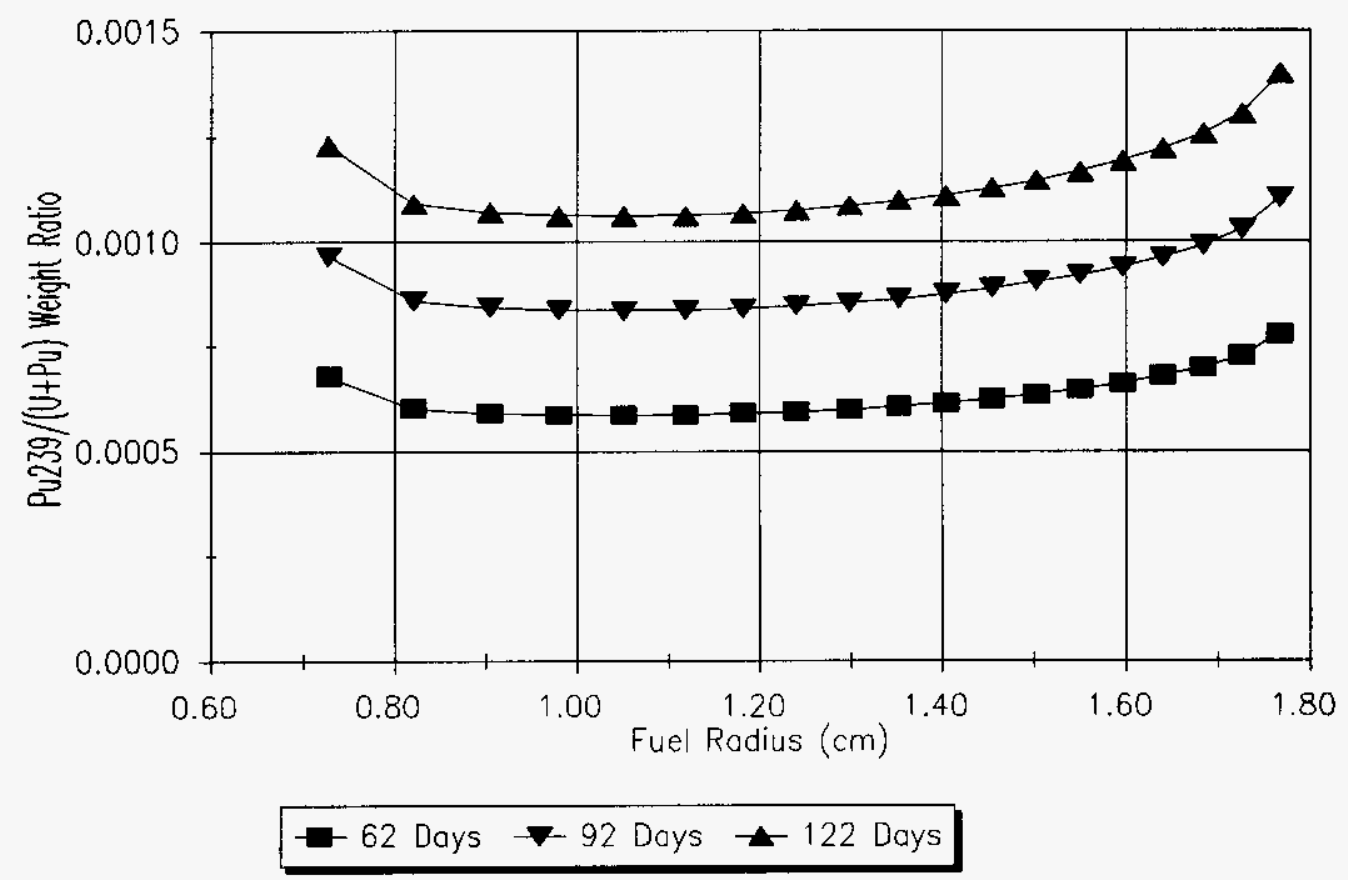




\section{HNF-SD-SNF-CSER-005 REV 5}

Figure E-3. Evolution of the Uranium-235 Plus Plutonium-239 Radial Profile for Annular K Reactor Fuel.

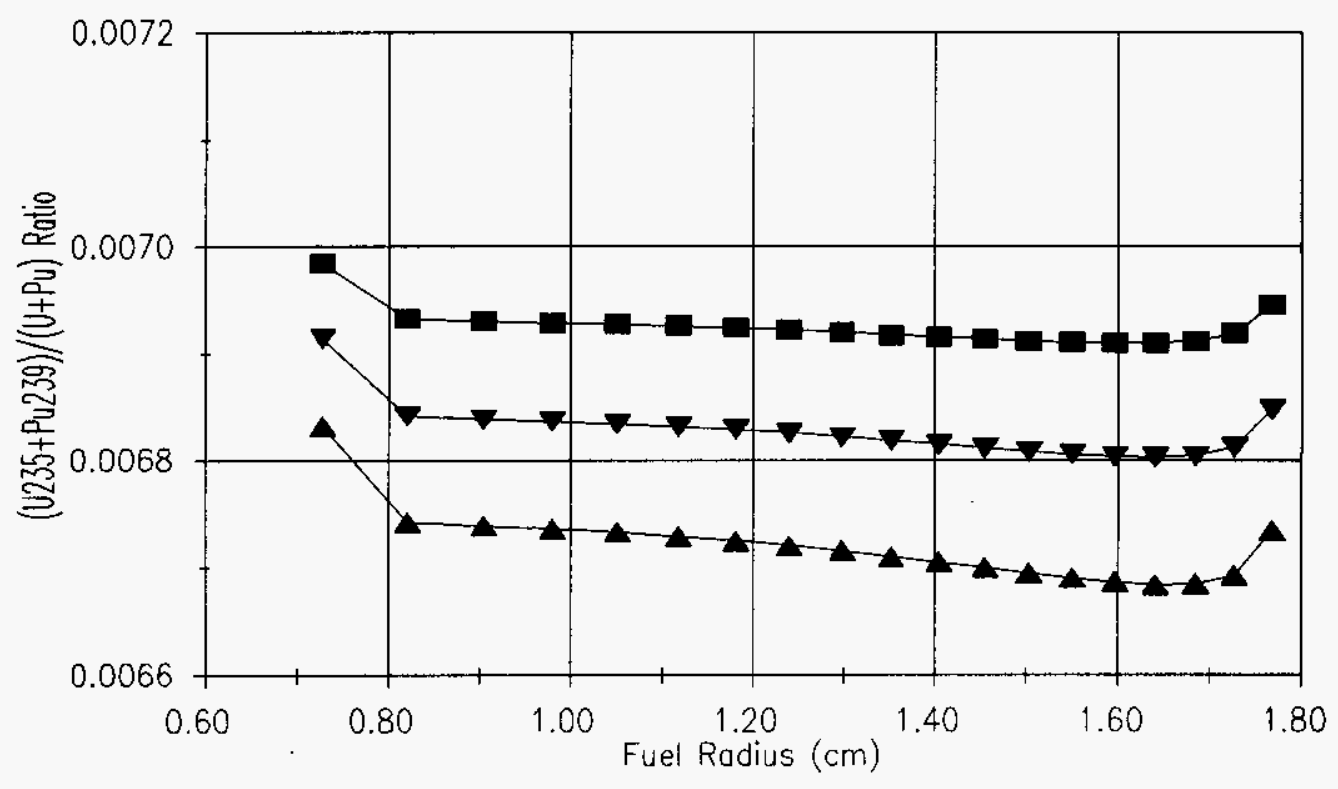

-62 Days $\rightarrow 92$ Days $\_122$ Days

Figure E-4. Evolution of the Weight Percent Plutonium-240 Radial Profile for Annular K Reactor Fuel.

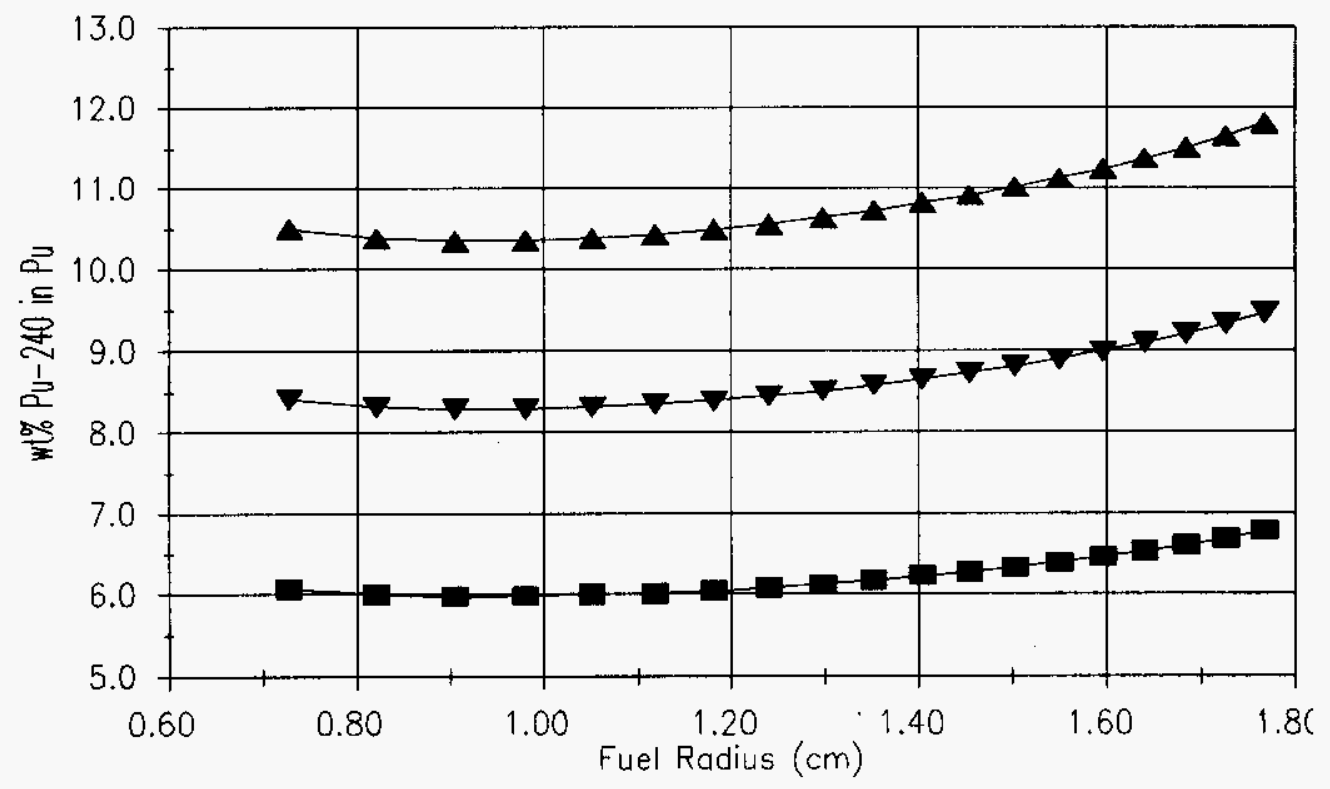

- 62 Days $\rightarrow 92$ Days $\leftarrow 122$ Days 


\section{HNF-SD-SNF-CSER-005 REV 5}

Figure E-5. Evolution of the Uranium-235 Radial Profile for N Reactor Mark IV Fuel.

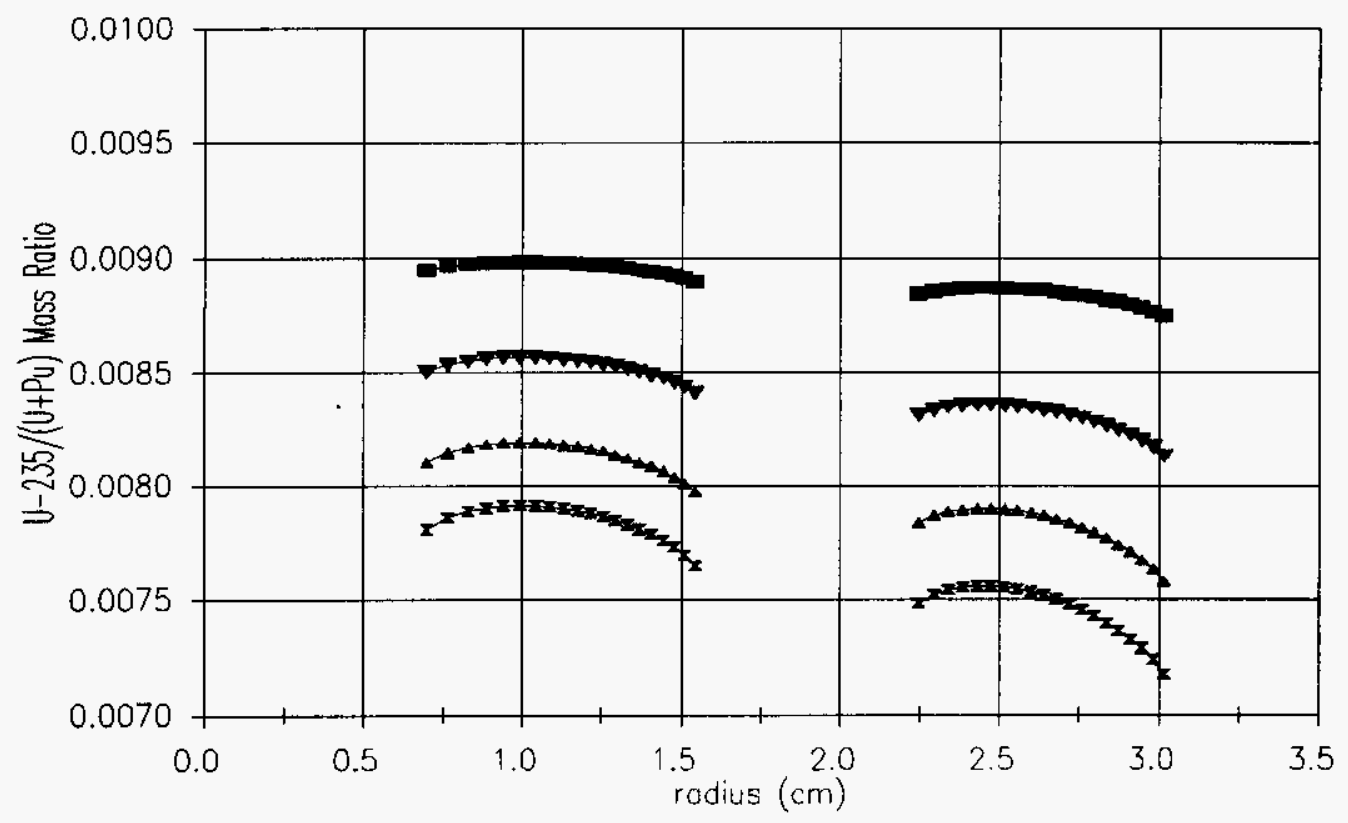

$\rightarrow-52$ days $\rightarrow 102$ days $\rightarrow 152$ days $\rightarrow 192$ days

Figure E-6. Evolution of the Plutonium-239 Radial Profile for N Reactor Mark IV Fuel.

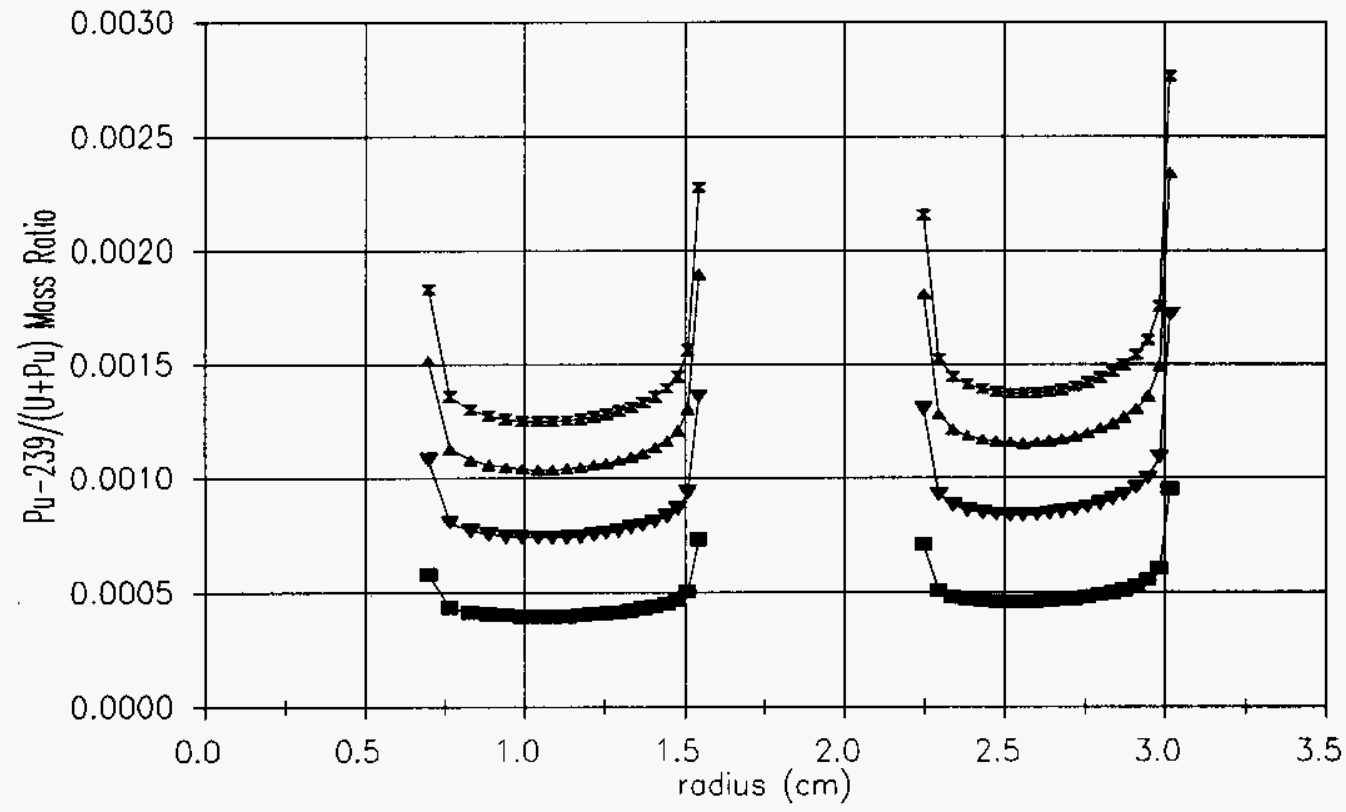

$\rightarrow 52$ days $\rightarrow 102$ days $\rightarrow 152$ days $\rightarrow-192$ days 


\section{HNF-SD-SNF-CSER-005 REV 5}

Figure E-7. Evolution of the Uranium-235 Plus Plutonium-239 Radial Profile for N Reactor Mark IV Fuel.

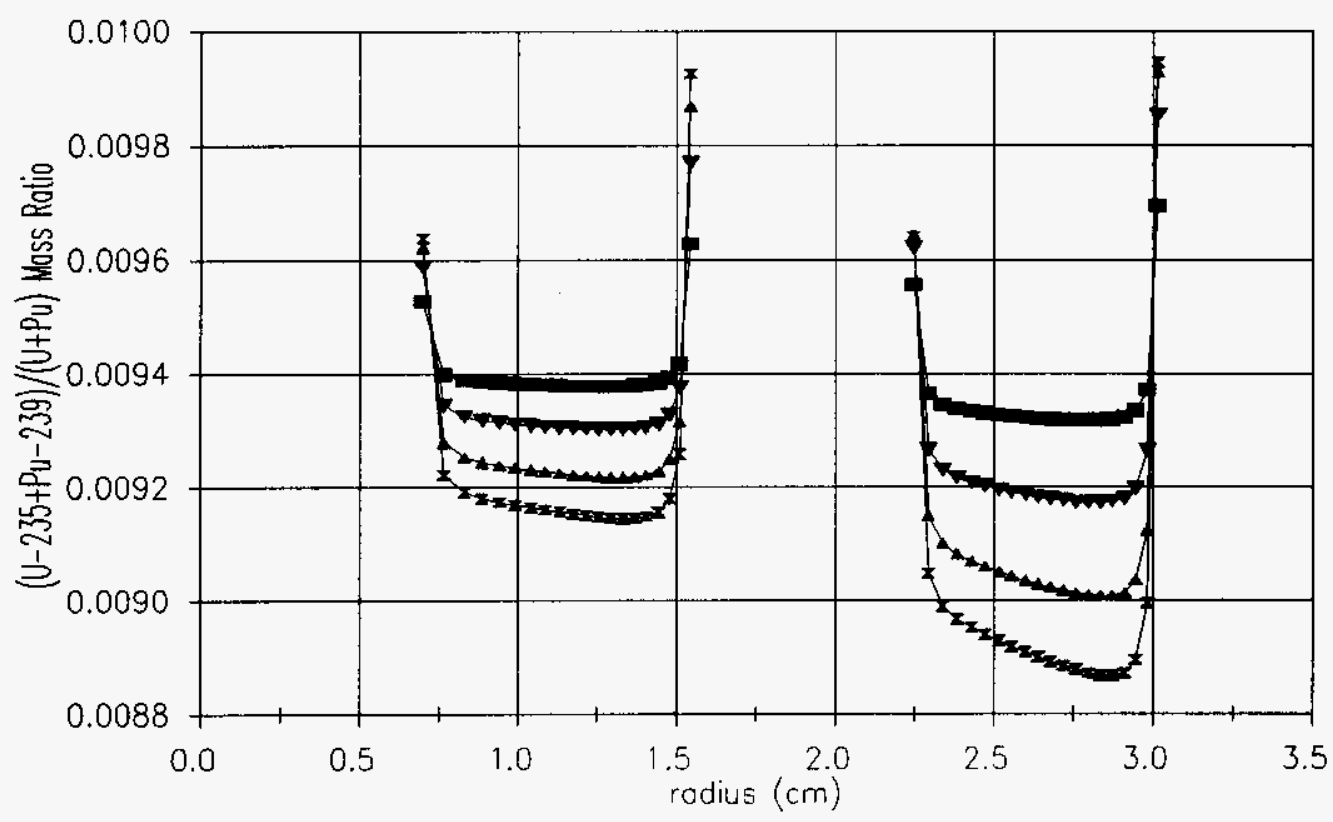

-52 days $\rightarrow 102$ days $\rightarrow 152$ doys $\rightarrow 192$ days

Figure E-8. Evolution of the Weight Percent Plutonium-240 Radial Profile for N Reactor Mark IV Fuel.

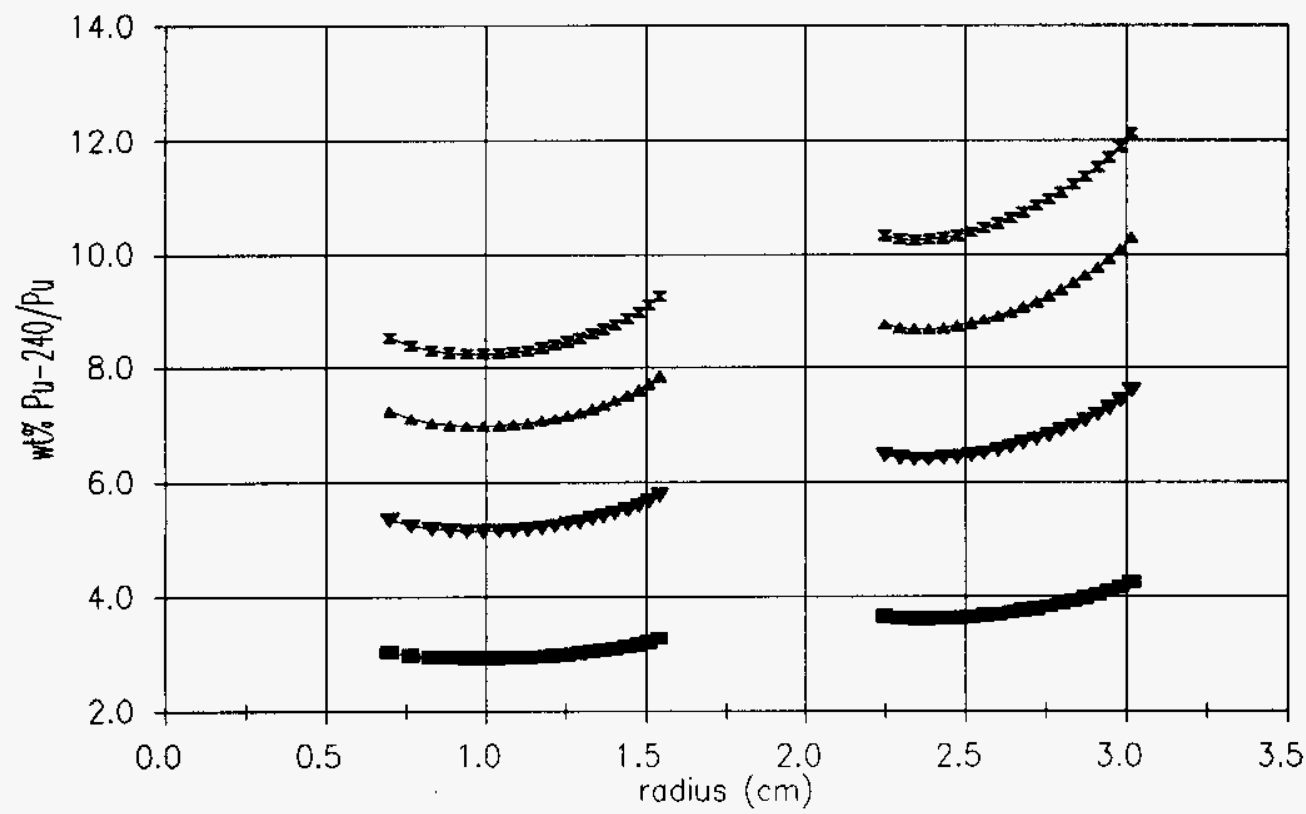

-52 days $\rightarrow 102$ days $\rightarrow 152$ days $\rightarrow 192$ days 


\section{HNF-SD-SNF-CSER-005 REV 5}

Figure E-9. Evolution of the Uranium-235 Radial Profile for N Reactor Mark IA Fuel.

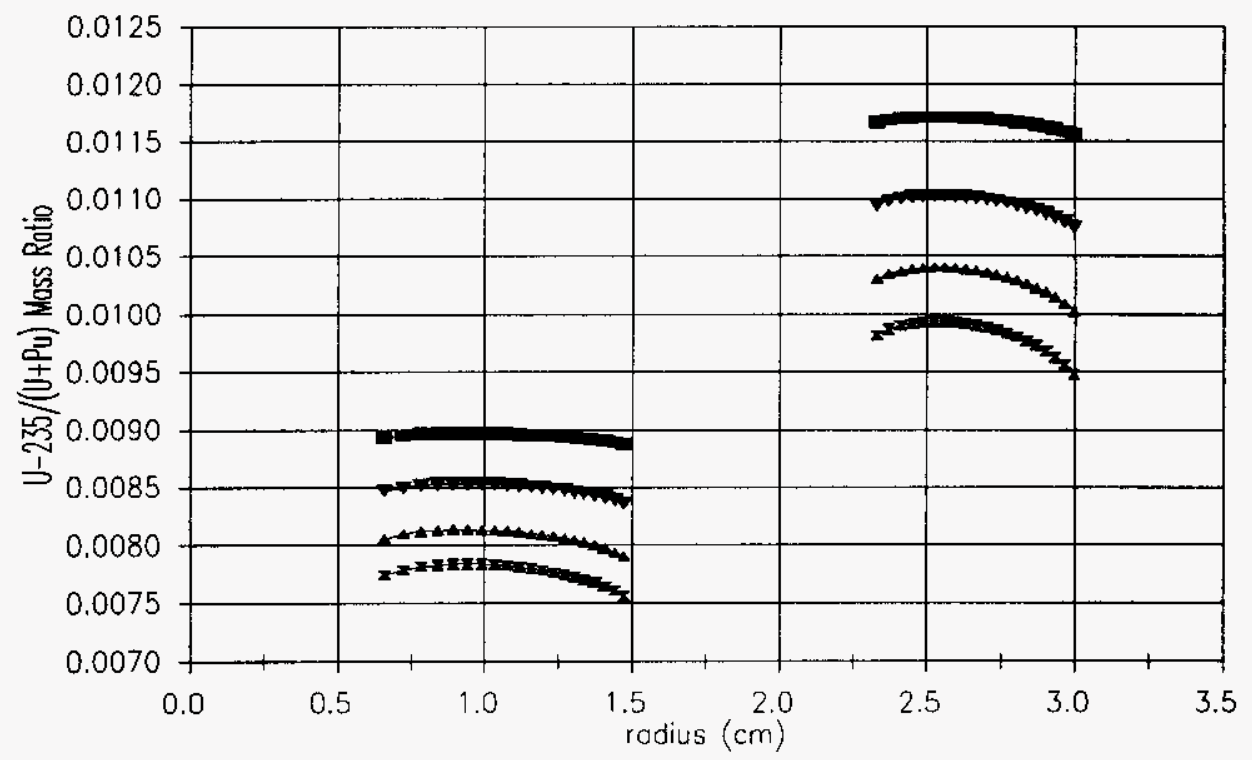

$\rightarrow 52$ days $\rightarrow 102$ days $\_152$ days $\rightarrow 192$ days

Figure E-10. Evolution of the Plutonium-239 Radial Profile for N Reactor Mark IA Fuel.

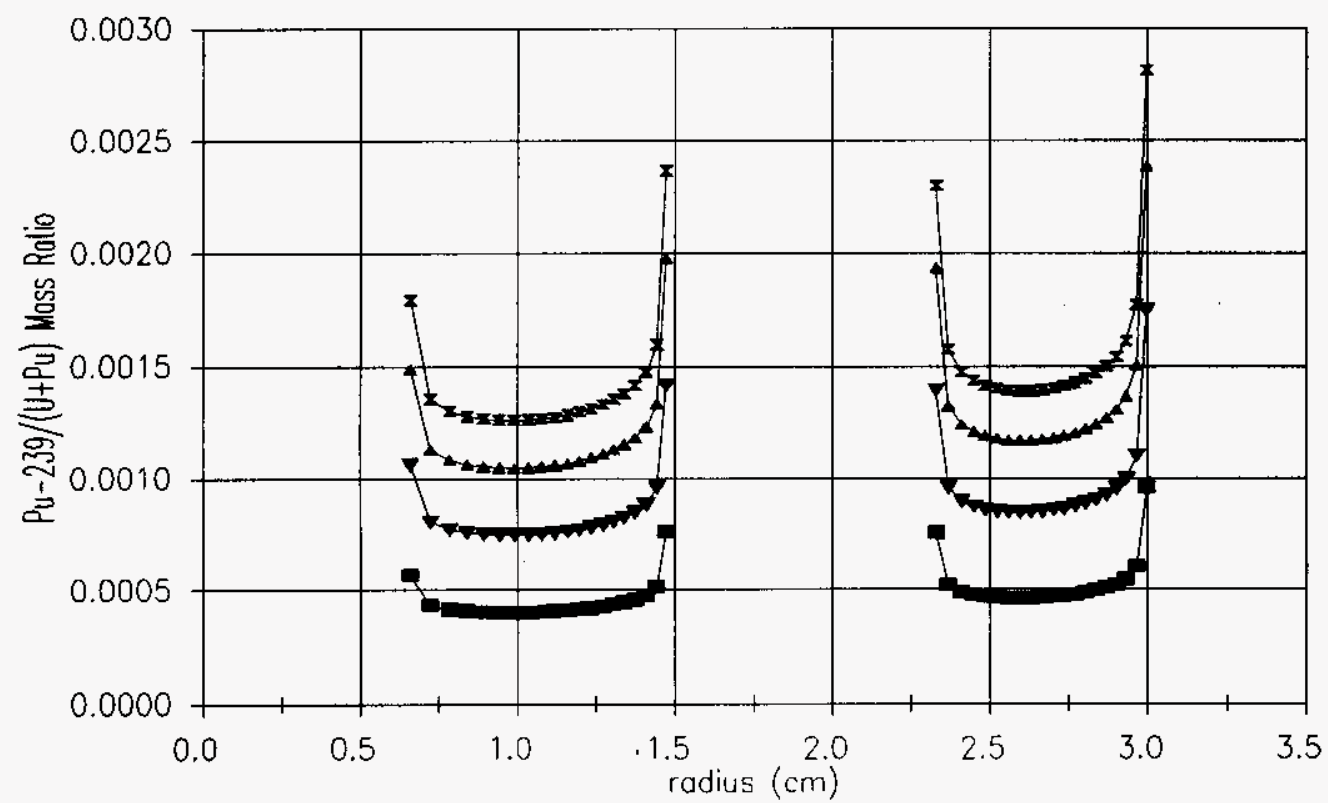

-52 days $\rightarrow 102$ days $\rightarrow 152$ days $\rightarrow 192$ days 
Figure E-11. Evolution of the Uranium-235 Plus Plutonium-239 Radial Profile for N Reactor Mark IA Fuel.

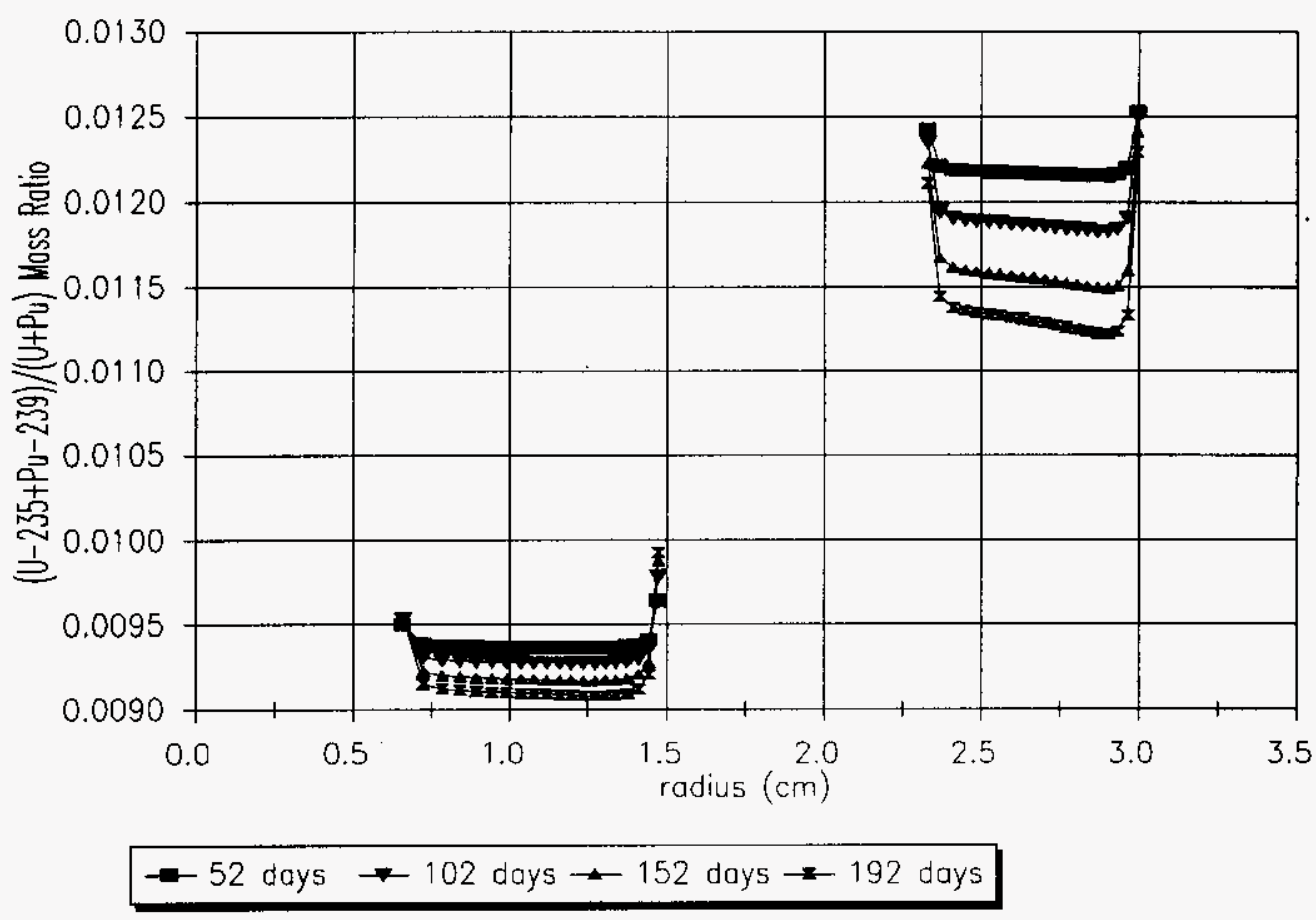

Figure E-12. Evolution of the Weight Percent Plutonium-240 Radial Profile for N Reactor Mark IA Fuel.

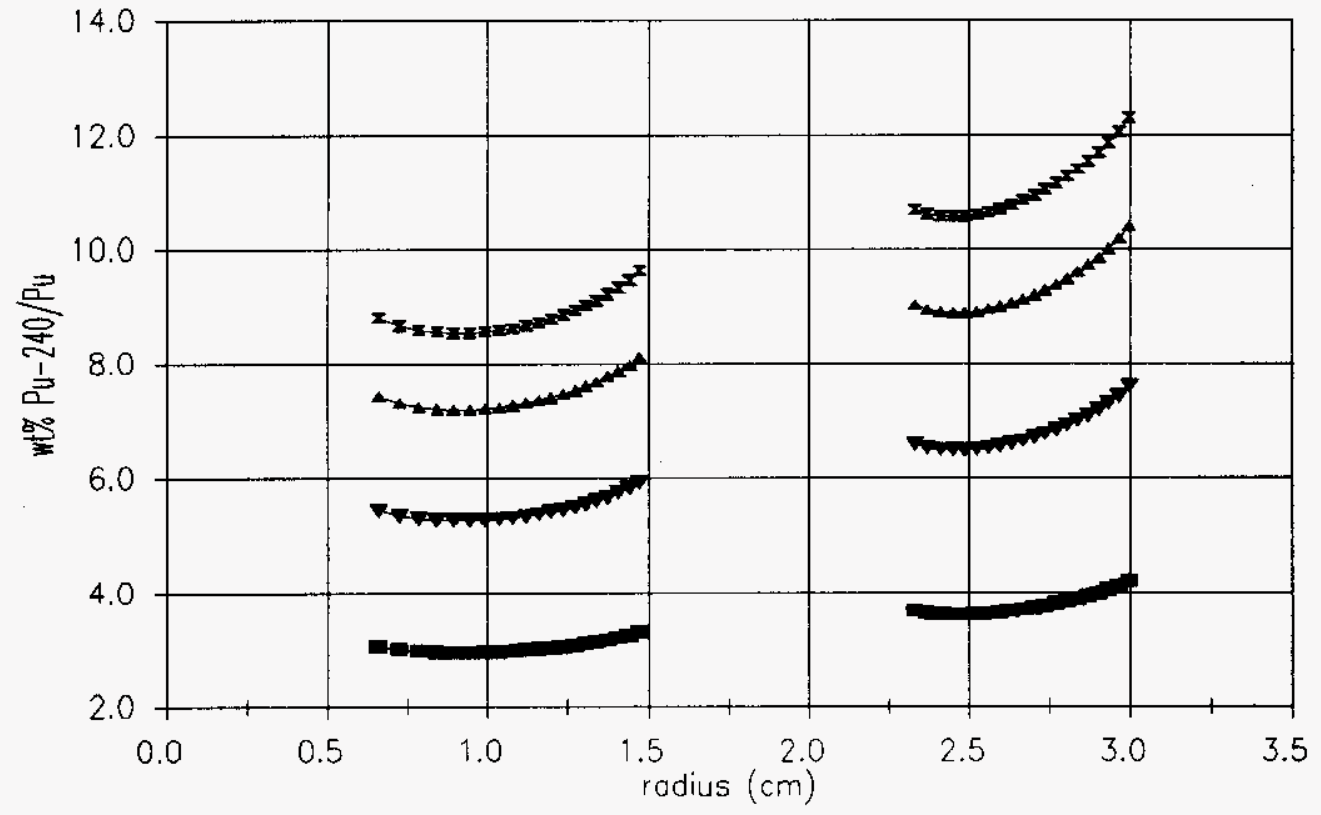

$\rightarrow-52$ days $\rightarrow 102$ days $\rightarrow 152$ days $\rightarrow 192$ days 
HNF-SD-SNF-CSER-005 REV 5

This page intentionally left blank. 
HNF-SD-SNF-CSER-005 REV 5

\section{APPENDIX F}

REPRESENTATIVE MCNP INPUT FILES 


\section{HNF-SD-SNF-CSER-005 REV 5}

This page intentionally left blank. 
HNF-SD-SNF-CSER-005 REV 5

\section{APPENDIX F}

\section{REPRESENTATIVE MCNP INPUT FILES}

\section{F.1 MARK 1A HIGHEST $k_{e f r}$ BASE CASE}

Basic model for MCO loaded with 2 scrap baskets and 4 fuel baskets. Each scrap

c basket filled with $575 \mathrm{~kg} \mathrm{Mk}$ I A scrap, flooded MCO in water

c fuel baskets full. Revised center post ID

c empty location 4,5

c fuel basket containing intact fuel assemblies

$\begin{array}{llllllllll}2 & 0 & -17 & 18 & -19 & 20 & -21 & 22 & \mathrm{u}=8 & \text { lat }=2\end{array}$ fill $=-5: 5 \quad-5: 5 \quad 0: 0$

$\begin{array}{lllllllllllll}2 & 2 & 2 & 2 & 2 & 2 & 2 & 2 & 2 & 2 & 2 & \$ 1\end{array}$

$\begin{array}{lllllllllllll}2 & 2 & 2 & 2 & 2 & 2 & 3 & 3 & 3 & 2 & 2 & \$ & 2\end{array}$

$\begin{array}{lllllllllllll}2 & 2 & 2 & 2 & 3 & 3 & 3 & 3 & 3 & 3 & 2 & \$ 3\end{array}$

$\begin{array}{lllllllllllll}2 & 2 & 2 & 3 & 2 & 3 & 3 & 3 & 3 & 3 & 2 & \$ 4 & 4\end{array}$

$\begin{array}{lllllllllllll}2 & 2 & 3 & 3 & 3 & 2 & 2 & 3 & 3 & 3 & 2 & \$ 5\end{array}$

$\begin{array}{lllllllllllll}2 & 2 & 3 & 3 & 2 & 2 & 2 & 3 & 3 & 2 & 2 & \$ 6 \text { level } 1\end{array}$

$\begin{array}{lllllllllllll}2 & 3 & 3 & 3 & 2 & 2 & 3 & 3 & 3 & 2 & 2 & \$ 7\end{array}$

$\begin{array}{lllllllllllll}2 & 3 & 3 & 3 & 3 & 3 & 3 & 3 & 2 & 2 & 2 & \$ 8\end{array}$

$\begin{array}{lllllllllllll}2 & 3 & 3 & 3 & 3 & 3 & 3 & 2 & 2 & 2 & 2 & \$ 9\end{array}$

$\begin{array}{llllllllllll}2 & 2 & 3 & 3 & 3 & 2 & 2 & 2 & 2 & 2 & 2 & \$ 10\end{array}$

$\begin{array}{llllllllllll}2 & 2 & 2 & 2 & 2 & 2 & 2 & 2 & 2 & 2 & 2 & \$ 11\end{array}$

$\begin{array}{lllllllllllll}c & 1 & 2 & 3 & 4 & 5 & 6 & 7 & 8 & 9 & 10 & 11\end{array}$

c Mark 1A scrap optimized lattice

$50 \quad-1112-1314-1516$ fill=4 $u=1$ lat=2 $\$$ scrap hex

$\begin{array}{lllll}6 & 4 & -18.8200-5 & \mathrm{u}=4 & \$ \text { scrap pin }\end{array}$

$\begin{array}{lllll}7 & 10 & -6.490005-6 & \mathrm{u}=4 & \$ \text { scrap clad }\end{array}$

$8236-1.000006 \quad u=4 \quad \$$ scrap cell

c Scrap basket

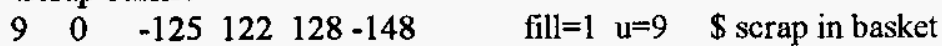

$\begin{array}{llllllll}10 & 236 & -1.00000 & 148 & -125 & 128 & \mathrm{u}=9 & \text { \$ water above scrap }\end{array}$

$\begin{array}{llllll}11 & 236 & -1.00 & -127 & u=9 & \$ \text { pipe interior }\end{array}$

$\begin{array}{llllllll}12 & 20 & -8.03 & 127 & -128 & 122 & u=9 & \$ \text { p pipe wall }\end{array}$

$\begin{array}{lllllll}13 & 20 & -8.03 & -122 & 127 & \mathrm{u}=9 & \$ \text { basket base }\end{array}$

$\begin{array}{lllllll}14 & 20 & -8.03 & 125 & 122 & \mathrm{u}=9 & \$ \text { basket side }\end{array}$

c fictitious water cell for fuel basket lattice

$\begin{array}{lllll}24 & 236 & -1.00 & -144 \quad \mathrm{u}=2 & \$ \text { fictitious cl }\end{array}$

c fuel basket

$\begin{array}{lllllllll}25 & 20 & -8.03 & -128 & 127 & 122 & -123 & \mathrm{u}=7 & \$ \text { tube wall }\end{array}$

$\begin{array}{lllllll}26 & 236 & -1.00 & -127 & -123 & \mathrm{u}=7 & \$ \text { central tube }\end{array}$

$\begin{array}{lllllll}27 & 20 & -8.03 & -122 & 127 & \mathrm{u}=7 & \$ \text { bottom plate }\end{array}$

$\begin{array}{llllllll}28 & 20 & -8.03 & -128 & 127 & 123 & \mathrm{u}=7 & \$ \text { tube wall }\end{array}$

$\begin{array}{lllllll}29 & 236 & -1.00 & -127 & 123 & u=7 & \$ \text { central tube }\end{array}$

$\begin{array}{llllllll}31 & 236 & -1.00 & -125 & 128 & 123 & \mathrm{u}=7 & \$ \text { above fuel }\end{array}$

$\begin{array}{lllll}32 & 20 & -8.03000 & 125122 & \mathrm{u}=7 \quad \$ \text { fuel basket side }\end{array}$

$33 \quad 0-125122 \quad 128-123 \quad$ fill $=8 \mathrm{u}=7 \quad \$$ fuel in basket

c fuel and scrap basket stack

$51 \quad 0 \quad-149 \quad$ fill=9 $\quad \mathrm{u}=11 \quad \$$ bottom scrap basket

$52 \quad 0 \quad 146 \quad-149 \# 51 \quad$ trcl=2 fill=7 $\quad u=11 \quad \$$ fuel basket 


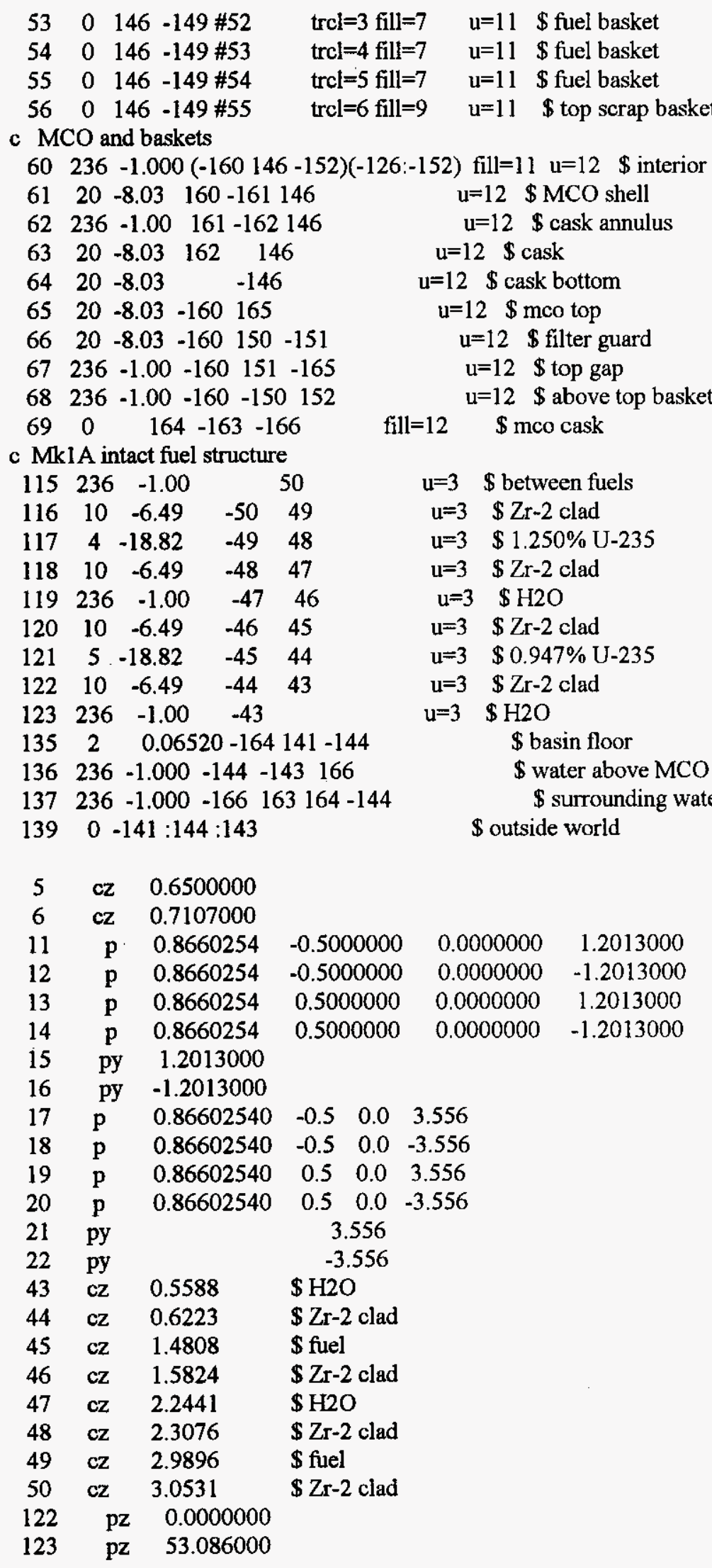




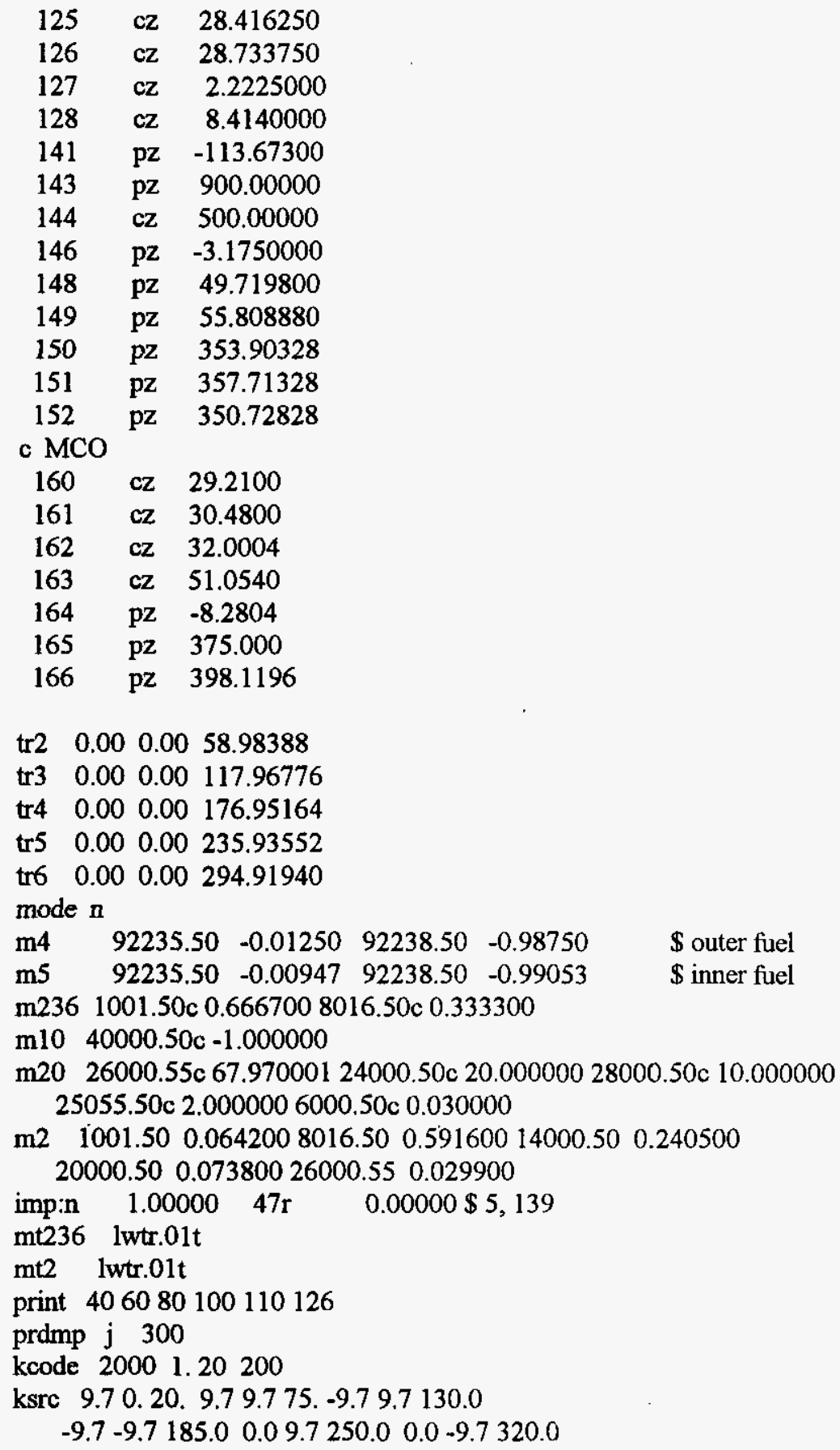




\section{F.2 MARK IV HIGHEST $k_{\text {efr }}$ BASE CASE}

Basic model for MCO loaded with 2 scrap baskets and 3 fuel baskets. Each scrap c basket filled with Mk 4 scrap, flooded MCO in water, no process tube in the c scrap baskets. Revised 1.25 " basket base plates for all baskets.

c Partially loaded fuel baskets, inner only in location 3,6

c fuel basket containing intact fuel assemblies

$\begin{array}{llllllllll}2 & 0 & -17 & 18 & -19 & 20 & -21 & 22 & u=8 & \text { lat }=2\end{array}$ fill $=-5: 5 \quad-5: 5 \quad 0: 0$

$\begin{array}{lllllllllllll}2 & 2 & 2 & 2 & 2 & 2 & 2 & 2 & 2 & 2 & 2 & \$ 1 & 1\end{array}$

$\begin{array}{lllllllllllll}2 & 2 & 2 & 2 & 2 & 2 & 3 & 3 & 3 & 2 & 2 & \$ & 2\end{array}$

$\begin{array}{lllllllllllll}2 & 2 & 2 & 2 & 3 & 15 & 3 & 3 & 3 & 3 & 2 & \$ 3\end{array}$

$\begin{array}{lllllllllllll}2 & 2 & 2 & 3 & 3 & 3 & 3 & 3 & 3 & 3 & 2 & \$ & 4\end{array}$

$\begin{array}{lllllllllllll}2 & 2 & 3 & 3 & 3 & 3 & 3 & 3 & 3 & 3 & 2 & \$ 5\end{array}$

$\begin{array}{llllllllllll}2 & 2 & 3 & 3 & 3 & 2 & 3 & 3 & 3 & 2 & 2 & \$ 6 \\ 6 & \text { level } 1\end{array}$

$\begin{array}{lllllllllllll}2 & 3 & 3 & 3 & 3 & 3 & 3 & 3 & 3 & 2 & 2 & \$ 7\end{array}$

$\begin{array}{lllllllllllll}2 & 3 & 3 & 3 & 3 & 3 & 3 & 3 & 2 & 2 & 2 & \$ 8\end{array}$

$\begin{array}{lllllllllllll}2 & 3 & 3 & 3 & 3 & 3 & 3 & 2 & 2 & 2 & 2 & \$ 9\end{array}$

$\begin{array}{llllllllllll}2 & 2 & 3 & 3 & 3 & 2 & 2 & 2 & 2 & 2 & 2 & \$ 10\end{array}$

$\begin{array}{llllllllllll}2 & 2 & 2 & 2 & 2 & 2 & 2 & 2 & 2 & 2 & 2 & \$ 11\end{array}$

$\begin{array}{lllllllllllll}c & & 1 & 2 & 3 & 4 & 5 & 6 & 7 & 8 & 9 & 10 & 11\end{array}$

c Mark 4 scrap optimized lattice

$50 \quad-1112-1314-1516$ fill=4 $u=1$ lat=2 \$ scrap hex

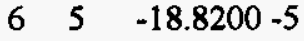

$\begin{array}{lll}7 & 10 & -6.490005-6\end{array}$

$\mathrm{u}=4 \quad \$$ scrap pin

$8236-1.000006$

$u=4 \quad \$$ scrap clad

$\mathrm{u}=4 \quad \$$ scrap cell

c Scrap basket

$\begin{array}{llll}9 & 0 & -125 & 122\end{array}$

$\begin{array}{lllll}11 & 236 & -1.00 & -127 & -122\end{array}$

$\begin{array}{lllll}13 & 20 & -8.03 & -122 & 127\end{array}$

fill=1 $u=9 \quad \$$ scrap in basket

u=9 $\$$ pipe interior

u=9 $\$$ basket base

$\mathrm{u}=9 \quad \$$ basket side

$\begin{array}{lllll}14 & 20 & -8.03 & 125 & 122\end{array}$

c fictitious water cell for fuel basket lattice

$\begin{array}{llllll}24 & 236 & -1.00 & -144 & \mathrm{u}=2 & \$ \text { fictitious } \mathrm{cl}\end{array}$

c fuel basket

$\begin{array}{lllllllll}25 & 20 & -8.03 & -128 & 127 & 122 & -123 & u=7 & \$\end{array}$ tube wall

$\begin{array}{lllllll}26 & 236 & -1.00 & -127 & -123 & \mathrm{u}=7 & \$ \text { central tube }\end{array}$

$\begin{array}{llllll}27 & 20 & -8.03 & -122 & 127-130 & u=7\end{array}$ \$ bottom plate

$\begin{array}{llllllll}28 & 20 & -8.03 & -128 & 127 & 123 & \mathrm{u}=7 & \$ \text { tube wall }\end{array}$

$\begin{array}{llllllll}29 & 236 & -1.00 & -127 & 123 & \mathrm{u}=7 & \$ \text { central tube }\end{array}$

$\begin{array}{llllllll}31 & 236 & -1.00 & -129 & 128 & 123 & \mathrm{u}=7 & \$ \text { above fuel }\end{array}$

$\begin{array}{lllllll}32 & 20 & -8.03000 & 129 & 122 & -130 \quad \mathrm{u}=7 \quad \$ \text { fuel basket side }\end{array}$

$33 \quad 0 \quad-129122 \quad 128-123 \quad$ fill $=8 u=7 \quad \$$ fuel in basket

$\begin{array}{llll}34 & 236 & -1.00 \quad 130\end{array}$

$\mathrm{u}=7 \quad \$$ outside fuel basket

c fuel and scrap basket stack

$\begin{array}{llllll}51 & 0 & -149 \quad \text { fill }=9 \quad \mathrm{u}=11 \quad \text { \$ bottom scrap basket }\end{array}$

$52 \quad 0 \quad 146-149 \# 51 \quad$ trcl=2 fill=7 $u=11 \quad \$$ fuel basket

$53 \quad 0 \quad 146-149 \# 52 \quad$ trcl=3 fill=7 $\quad \mathrm{u}=11 \quad$ \$ fuel basket

$54 \quad 0 \quad 146-149 \# 53 \quad$ trcl=4 fill=7 $\quad \mathrm{u}=11 \quad \$$ fuel basket

$55 \quad 0 \quad 146-149 \# 54 \quad$ trcl=5 fill $=9 \quad \mathrm{u}=11 \quad \$$ top scrap basket

$59 \quad 236-1.000 \quad 152 \# 55 \quad u=11 \quad$ \$ above top basket

c MCO and baskets

$600 \quad(-160146-150)(-126:-150)$ fill $=11 \mathrm{u}=12 \quad \$$ interior

$\begin{array}{lllllll}61 & 20 & -8.03 & 160-161 & 146 \quad u=12 & \$ M C O & \text { shell }\end{array}$ 


\section{HNF-SD-SNF-CSER-005 REV 5}

$$
\begin{aligned}
& \begin{array}{llllll}
62 & 236 & -1.00 & 161 & -162 & 146
\end{array} \\
& \begin{array}{lllll}
63 & 20 & -8.03 & 162 & 146
\end{array} \\
& \begin{array}{llll}
64 & 20 & -8.03 & -146
\end{array} \\
& \begin{array}{lllll}
65 & 20 & -8.03 & -160 & 165
\end{array} \\
& \begin{array}{llllll}
66 & 20 & -8.03 & -160 & 150 & -151
\end{array} \\
& \begin{array}{llllll}
67 & 236 & -1.00 & -160 & 151 & -165
\end{array} \\
& \begin{array}{llllll}
68 & 0 & 164 & -163 & -166
\end{array}
\end{aligned}
$$

c Mk4 inner fuel structure

\begin{tabular}{|c|c|c|c|c|}
\hline 115 & 236 & -1.00 & & 50 \\
\hline 116 & 10 & -6.49 & -50 & 49 \\
\hline 117 & 5 & -18.82 & -49 & 48 \\
\hline 118 & 10 & -6.49 & -48 & 47 \\
\hline 119 & 236 & -1.00 & -47 & 46 \\
\hline 120 & 10 & -6.49 & -46 & 45 \\
\hline 121 & 5 & -18.82 & -45 & 44 \\
\hline 122 & 10 & -6.49 & -44 & 43 \\
\hline 123 & 236 & -1.00 & -43 & \\
\hline 35 & 2 & 0.0652 & $0-164$ & $141-144$ \\
\hline 136 & 236 & -1.000 & $144-1$ & 143166 \\
\hline 37 & 236 & $-1.000-1$ & 16616 & $63164-144$ \\
\hline & 0. & 144 & & \\
\hline
\end{tabular}
$\begin{array}{llll}80 & 236 & -1.00 & 46\end{array}$

$\begin{array}{lllll}81 & 10 & -6.49 & -46 & 45\end{array}$

$\begin{array}{lllll}82 & 5 & -18.82 & -45 & 44\end{array}$

$\begin{array}{lllll}83 & 10 & -6.49 & -44 & 43\end{array}$

$\begin{array}{llll}84 & 236 & -1.00 & -43\end{array}$

c Mk4 intact fuel structure $\mathrm{u}=12 \$$ cask annulus

$\mathrm{u}=12 \$$ cask

$\mathrm{u}=12 \$$ cask bottom

$\mathrm{u}=12 \$$ mco top

$u=12 \$$ filter guard

$\mathrm{u}=12 \$$ top gap

fill=12 \$ mco cask

$$
\begin{array}{cl}
u=15 & \$ \text { between fuels } \\
u=15 & \$ \mathrm{Zr}-2 \text { clad } \\
\mathrm{u}=15 & \$ 0.947 \% \mathrm{U}-235 \\
\mathrm{u}=15 & \$ \mathrm{Zr}-2 \text { clad } \\
\mathrm{u}=15 & \$ \mathrm{H} 2 \mathrm{O} \\
& \\
\mathrm{u}=3 & \$ \text { between fuels } \\
\mathrm{u}=3 & \$ \mathrm{Zr}-2 \text { clad } \\
\mathrm{u}=3 & \$ 0.947 \% \mathrm{U}-235 \\
\mathrm{u}=3 & \$ \mathrm{Zr}-2 \text { clad } \\
\mathrm{u}=3 & \$ \mathrm{H} 2 \mathrm{O} \\
\mathrm{u}=3 & \$ \mathrm{Zr}-2 \text { clad } \\
\mathrm{u}=3 & \$ 0.947 \% \mathrm{U}-235 \\
\mathrm{u}=3 & \$ \mathrm{Zr}-2 \text { clad } \\
\mathrm{u}=3 & \$ \mathrm{H} 2 \mathrm{O} \\
& \$ \text { basin floor } \\
& \$ \text { water above MCO } \\
& \$ \text { surrounding water } \\
& \$ \text { outside world }
\end{array}
$$

$\begin{array}{rr}0.0000000 & 1.3992000 \\ 0.0000000 & -1.3992000 \\ 0.0000000 & 1.3992000 \\ 0.0000000 & -1.3992000\end{array}$

15 py 1.3992000

16 py -1.3992000

$\begin{array}{llllll}17 & \mathrm{p} & 0.86602540 & -0.5 & 0.0 & 3.556\end{array}$

$\begin{array}{llllll}18 & \mathrm{p} & 0.86602540 & -0.5 & 0.0 & -3.556\end{array}$

$\begin{array}{llllll}19 & \mathrm{p} & 0.86602540 & 0.5 & 0.0 & 3.556\end{array}$

$\begin{array}{llllll}20 & \mathrm{p} & 0.86602540 & 0.5 & 0.0 & -3.556\end{array}$

21 py 3.556

22 py -3.556

$43 \mathrm{cz} \quad 0.6095 \quad \$ \mathrm{H} 2 \mathrm{O}$

$44 \mathrm{cz} \quad 0.6605 \quad \$ \mathrm{Zr}-2$ clad

$45 \mathrm{cz} \quad 1.5480 \quad \$$ fuel

$46 \mathrm{cz} \quad 1.6245 \quad \$ \mathrm{Zr}-2 \mathrm{clad}$

$47 \mathrm{cz} \quad 2.1605 \quad \$ \mathrm{H} 2 \mathrm{O}$

$48 \quad \mathrm{cz} \quad 2.2110 \quad \$ \mathrm{Zr}-2$ clad

$49 \mathrm{cz} 3.0165$ \$ fuel

$50 \mathrm{cz} \quad 3.0800 \quad \$ \mathrm{Zr}-2 \mathrm{clad}$

122 pz 0.0000000

$123 \mathrm{pz} 66.294000$

c scrap basket side

$125 \quad$ cz 28.77001997 


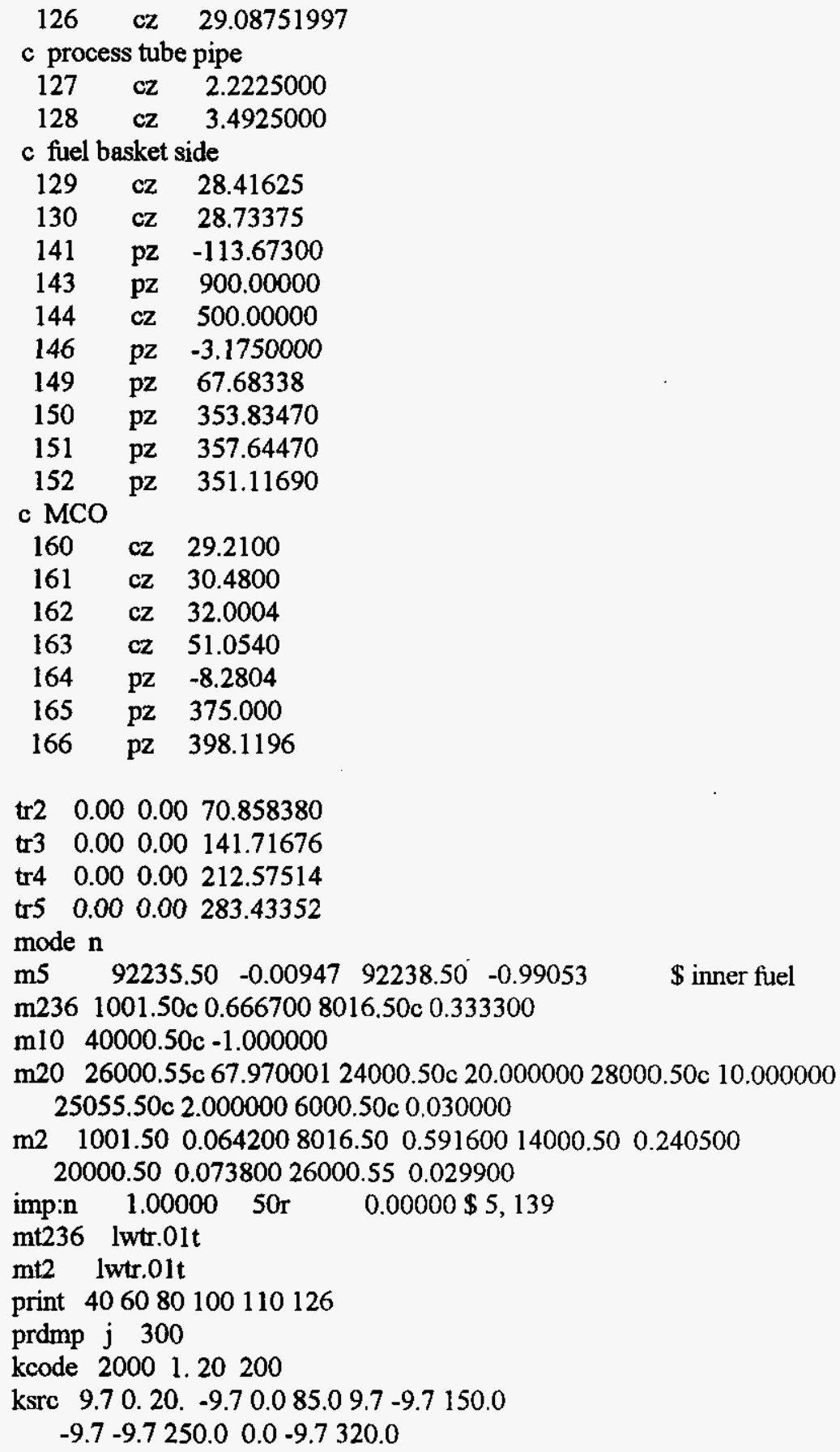




\section{F.3 SPR FUEL}

message:

multiple canister over-pack - RUN 1 - Normal SPR Case c $2.1 \mathrm{wt} \%$ material in the center of the basket
$\begin{array}{lllll}388 & 4 & -1.00 & -427\end{array}$
$\mathrm{u}=2$ imp: $\mathrm{n}=1 \$$ inner water
$\begin{array}{lllll}389 & 2 & -2.70 & 427 & -428\end{array}$
$\begin{array}{lllll}390 & 1 & -18.82 & 428 & -429\end{array}$
$u=2$ imp:n=1 $\$ 0.95$ clad
u=2 imp:n=1 $\$ 0.95$ fuel
$\begin{array}{lllll}391 & 2 & -2.70 & 429 & -430\end{array}$
$\mathrm{u}=2$ imp:n=1 $\$ 0.95 \mathrm{clad}$
$\begin{array}{llll}392 & 4 & -1.00 & 430\end{array}$
$\mathrm{u}=2$ imp: $\mathrm{n}=1$ \$ lattice water

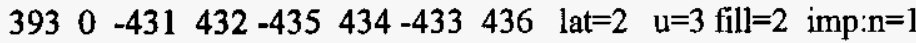
$\begin{array}{llll}394 & 4 & -1.00 & -437\end{array}$
$\mathrm{u}=4$ imp:n=1 $\$$ inner water
$\begin{array}{lllll}395 & 2 & -2.70 & 437 & -438\end{array}$
$\mathrm{u}=4 \mathrm{imp}: \mathrm{n}=1 \$ 2.1 \mathrm{clad}$

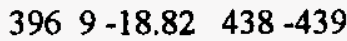
$\mathrm{u}=4$ imp:n=1 $\$ 2.1$ scrap
$\begin{array}{lllll}397 & 2 & -6.55 & 439 & -440\end{array}$
$u=4$ imp: $n=1 \$ 2.1$ clad
$398 \quad 4 \quad-1.00 \quad 440$
$\mathrm{u}=4$ imp: $n=1 \$$ lattice water

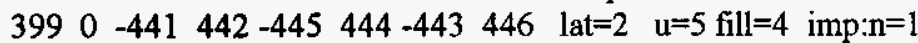

$400 \quad 4 \quad-1.00-404 \quad 405-401$

$\begin{array}{llllll}401 & 0 & -398 & -405 & 406 & 402\end{array}$

imp: $n=1 \$$ top water reflector

$\begin{array}{lllllll}402 & 3 & -8.03 & -405 & 407 & -402 & 403\end{array}$

fill=3 imp:n=1 \$ scrap in basket \#1

$\begin{array}{llllll}403 & 4 & -1.00 & -405 & 407 & -403\end{array}$

$\begin{array}{lllllll}404 & 3 & -8.03 & -406 & 407 & -398 & 402\end{array}$

$\begin{array}{lllllll}405 & 4 & -1.00 & -407 & 408 & -398 & 402\end{array}$

$\begin{array}{llllllllll}406 & 3 & -8.03 & -407 & 408 & -402 & 403\end{array}$

$\begin{array}{llllll}407 & 4 & -1.00 & -407 & 408 & -403\end{array}$

$\begin{array}{llllll}408 & 0 & -398 & -408 & 409 & 402\end{array}$

$\begin{array}{lllllll}409 & 3 & -8.03 & -408 & 409 & -402 & 403\end{array}$

$\begin{array}{llllll}410 & 4 & -1.00 & -408 & 409 & -403\end{array}$

$\begin{array}{lllllll}411 & 3 & -8.03 & -409 & 410 & -398 & 402\end{array}$

$\begin{array}{lllllll}412 & 4 & -1.00 & -410 & 411 & -398 & 402\end{array}$

$\begin{array}{lllllll}413 & 3 & -8.03 & -409 & 411 & -402 & 403\end{array}$

$\begin{array}{llllll}414 & 4 & -1.00 & -409 & 411 & -403\end{array}$

$\begin{array}{llllll}415 & 0 & -398 & -411 & 426 & 412\end{array}$

$\begin{array}{llllll}416 & 0 & -411 & -426 & 412 & 402\end{array}$

$\begin{array}{lllllll}417 & 3 & -8.03 & -411 & 412 & -402 & 403\end{array}$

$\begin{array}{llllll}418 & 4 & -1.00 & -411 & 412 & -403\end{array}$

$\begin{array}{lllllll}419 & 3 & -8.03 & -412 & 413 & -398 & 402\end{array}$

$\begin{array}{lllllll}420 & 4 & -1.00 & -413 & 414 & -398 & 402\end{array}$

$\begin{array}{lllllll}421 & 3 & -8.03 & -412 & 414 & -402 & 403\end{array}$

$\begin{array}{llllll}422 & 4 & -1.00 & -412 & 414 & -403\end{array}$

$\begin{array}{llllll}423 & 0 & -398 & -414 & 415 & 402\end{array}$

$\begin{array}{llllll}424 & 3 & -8.03 & -414 & 415 & -402\end{array}$

$\begin{array}{llllll}425 & 4 & -1.00 & -414 & 415 & -403\end{array}$

$\begin{array}{lllllll}426 & 3 & -8.03 & -415 & 416 & -398 & 402\end{array}$

$\begin{array}{lllllll}427 & 4 & -1.00 & -416 & 417 & -398 & 402\end{array}$

$\begin{array}{lllllll}428 & 3 & -8.03 & -415 & 417 & -402 & 403\end{array}$

$\begin{array}{llllll}429 & 4 & -1.00 & -415 & 417 & -403\end{array}$

$\begin{array}{llllll}430 & 0 & -398 & -417 & 418 & 402\end{array}$

$\begin{array}{llllll}431 & 3 & -8.03 & -417 & 418 & -402\end{array}$

403

$\begin{array}{llllll}432 & 4 & -1.00 & -417 & 418 & -403\end{array}$

$\begin{array}{lllllll}433 & 3 & -8.03 & -418 & 419 & -398 & 402\end{array}$

$\begin{array}{lllllll}434 & 3 & -8.03 & -418 & 419 & -402 & 403\end{array}$ imp:n=1 \$ ss insert in basket \#1 imp:n=1 \$ water inside ss insert imp: $n=1$ \$ ss plate \#1 imp: $n=1$ \$ water in gap \#2 imp:n=1 \$ ss insert in gap \#2 imp: $n=1 \$$ water inside ss insert

fill=3 imp:n=1 \$ scrap in basket \#2 imp:n=1 $\$$ ss insert in basket \#2 imp:n=1 $\$$ water inside ss insert imp:n=1 \$ ss plate \#2 imp:n=1 \$ water in gap \#3 imp:n=1 \$ ss insert in gap \#3 imp:n=1 $\$$ water inside ss insert

fill=3 imp:n=1 \$ scrap in basket \#3

fill=5 imp:n=1 \$ scrap in basket \#3 imp:n=1 \$ ss insert in basket \#3 imp:n=1 $\$$ water inside ss insert imp:n=1 \$ ss plate \#3 imp: $n=1$ \$ water in gap $\# 4$ imp:n=1 \$ ss insert in gap \#4 imp: $n=1 \$$ water inside ss insert

fill=3 imp:n=1 \$ scrap in basket \#4 imp: $n=1 \$$ ss insert in basket \#4 imp:n=1 $\$$ water inside ss insert imp:n=1 \$ ss plate \#4 imp:n=1 \$ water in gap \#5 imp:n=1 \$ ss insert in gap \#5 imp: $n=1 \$$ water inside ss insert

fill=3 imp:n=1 \$ scrap in basket \#5 imp: $n=1 \$$ ss insert in basket \#5 imp: $n=1 \$$ water inside ss insert imp: $n=1 \$$ ss plate \#5 imp:n=1 \$ ss insert in gap \#5 


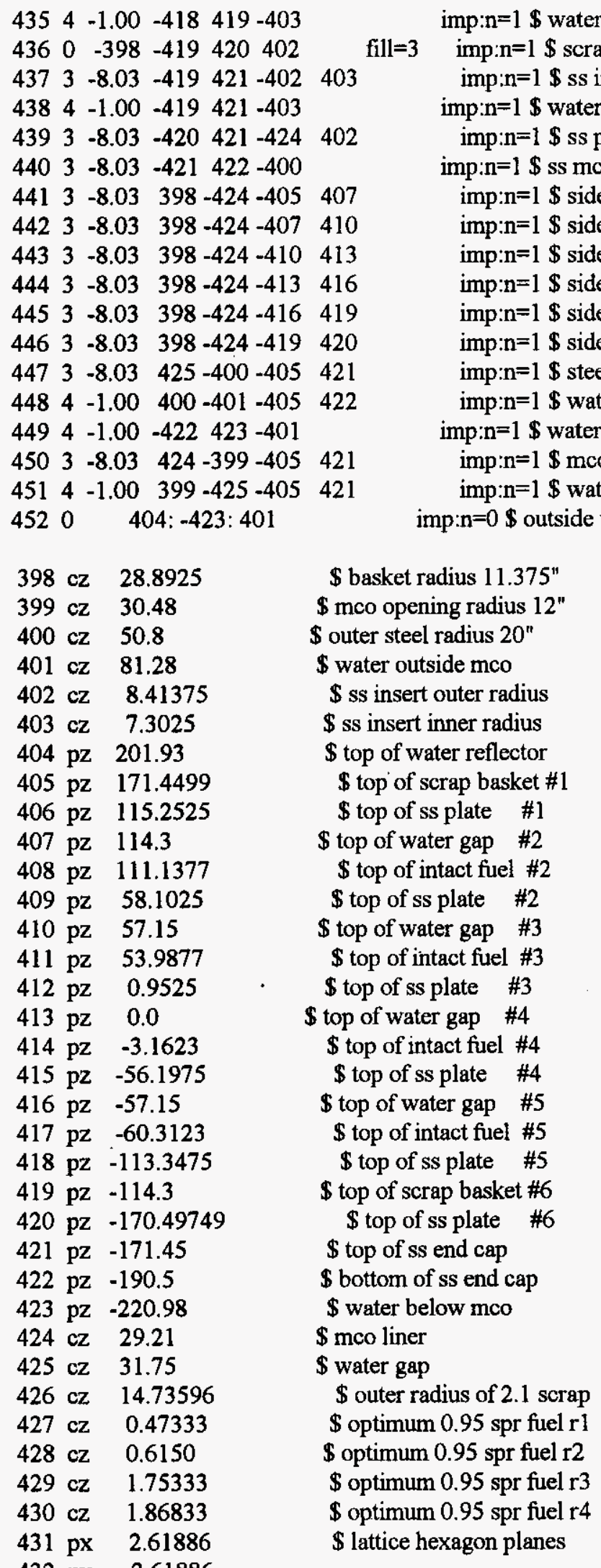




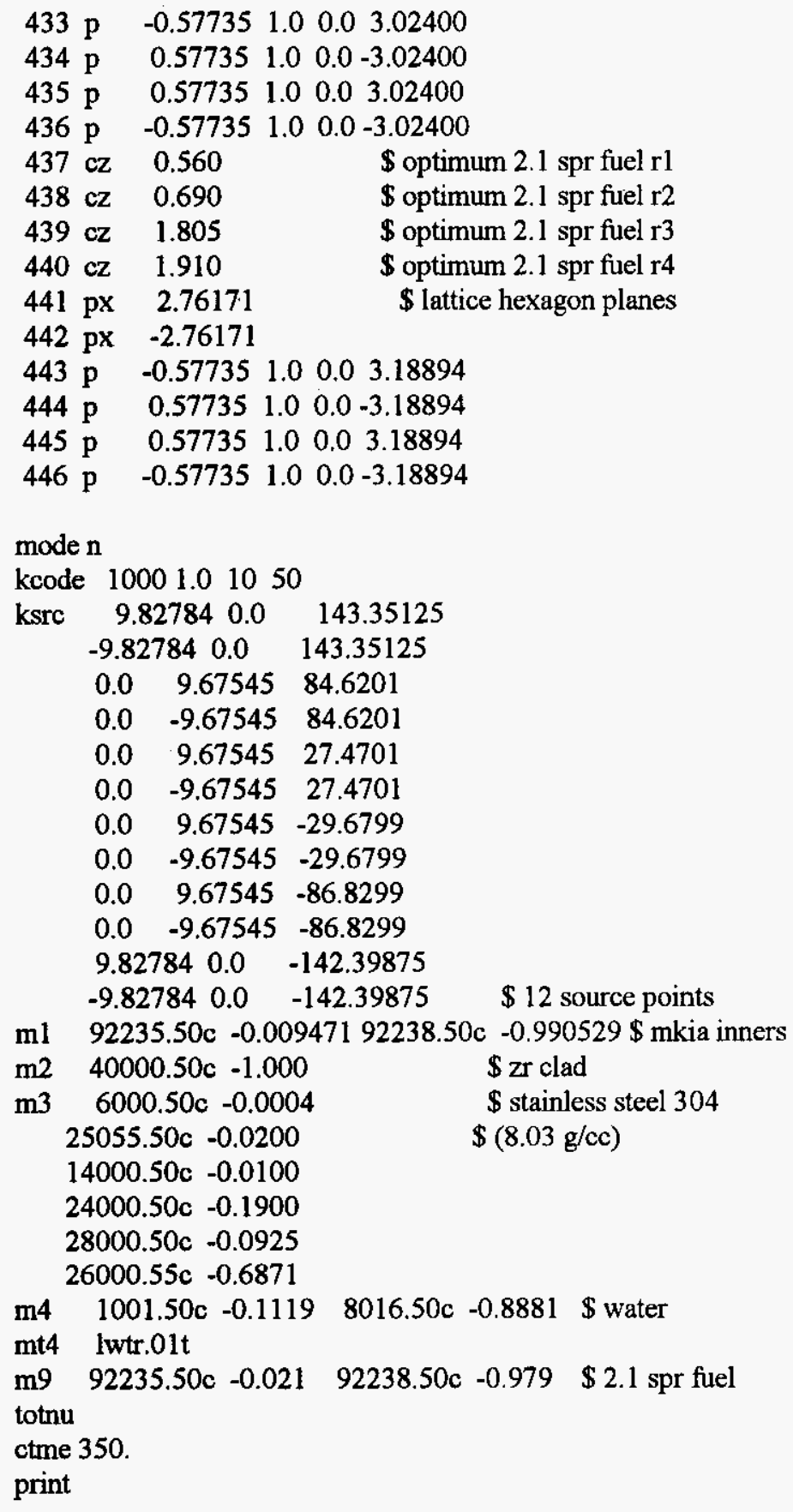




\section{F.4 PARTIALLY DRAINED MCO IN THE CVDF CONTAINING MARK 1A FUEL AND SCRAP}

Basic model for MCO loaded with 2 scrap baskets and 4 fuel baskets. Each scrap

c basket filled with $575 \mathrm{~kg} \mathrm{Mk}$ lA scrap, flooded MCO at CVDF

c fuel baskets full. Revised center post ID

c empty location 4,5

c The top scrap basket and all fuel baskets drained, The bottom

c scrap basket flooded half way.

c fuel basket containing intact fuel assemblies

$\begin{array}{llllllllll}2 & 0 & -17 & 18 & -19 & 20 & -21 & 22 & u=8 & \text { lat }=2\end{array}$

fill=-5:5 $\quad-5: 5 \quad 0: 0$

$\begin{array}{lllllllllllll}2 & 2 & 2 & 2 & 2 & 2 & 2 & 2 & 2 & 2 & 2 & \$ 1\end{array}$

$\begin{array}{lllllllllllll}2 & 2 & 2 & 2 & 2 & 2 & 3 & 3 & 3 & 2 & 2 & \$ & 2\end{array}$

$\begin{array}{lllllllllllll}2 & 2 & 2 & 2 & 3 & 3 & 3 & 3 & 3 & 3 & 2 & \$ & 3\end{array}$

$\begin{array}{lllllllllllll}2 & 2 & 2 & 3 & 2 & 3 & 3 & 3 & 3 & 3 & 2 & \$ & 4\end{array}$

$\begin{array}{lllllllllllll}2 & 2 & 3 & 3 & 3 & 2 & 2 & 3 & 3 & 3 & 2 & \$ 5\end{array}$

$\begin{array}{lllllllllllll}2 & 2 & 3 & 3 & 2 & 2 & 2 & 3 & 3 & 2 & 2 & \$ 6 & \text { level } 1\end{array}$

$\begin{array}{lllllllllllll}2 & 3 & 3 & 3 & 2 & 2 & 3 & 3 & 3 & 2 & 2 & \$ 7\end{array}$

$\begin{array}{lllllllllllll}2 & 3 & 3 & 3 & 3 & 3 & 3 & 3 & 2 & 2 & 2 & \$ 8\end{array}$

$\begin{array}{lllllllllllll}2 & 3 & 3 & 3 & 3 & 3 & 3 & 2 & 2 & 2 & 2 & \$ 9\end{array}$

$\begin{array}{llllllllllll}2 & 2 & 3 & 3 & 3 & 2 & 2 & 2 & 2 & 2 & 2 & \$ 10\end{array}$

$\begin{array}{llllllllllll}2 & 2 & 2 & 2 & 2 & 2 & 2 & 2 & 2 & 2 & 2 & \$ 11\end{array}$

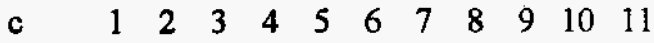

c Mark 1A scrap optimized lattice

$50 \quad-1112-1314-1516$ fill=4 $u=1$ lat=2 \$ scrap hex

$\begin{array}{lllll}6 & 4 & -18.8200-5 & \mathrm{u}=4 \quad \$ \text { scrap pin }\end{array}$

$\begin{array}{lllll}7 & 10 & -6.490005-6 & \mathrm{u}=4 & \$ \text { scrap clad }\end{array}$

$8236-1.000006 \quad u=4 \quad \$$ scrap cell

c Scrap basket

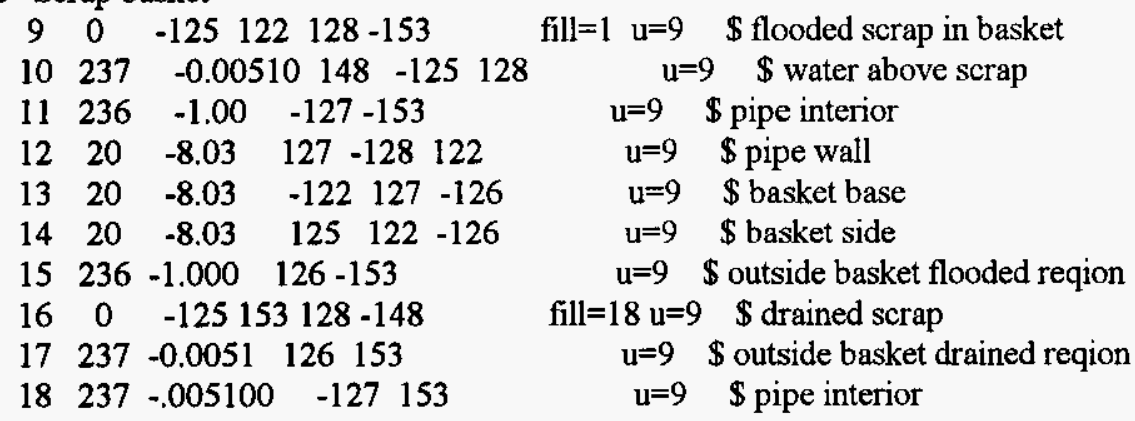

c fictitious water cell for fuel basket lattice

$\begin{array}{lllll}24 & 236 & -1.00 & -144 & \mathrm{u}=2\end{array} \quad \$$ fictitious cl

c fuel basket

$\begin{array}{lllllllll}25 & 20 & -8.03 & -128 & 127 & 122 & -123 & \mathrm{u}=7 & \$ \text { tube wall }\end{array}$

$\begin{array}{lllllll}26 & 236 & -1.00 & -127 & -123 & \mathrm{u}=7 & \$ \text { central tube }\end{array}$

$\begin{array}{lllllll}27 & 20 & -8.03 & -122 & 127 & -126 & \mathrm{u}=7\end{array}$

$\begin{array}{llllllll}28 & 20 & -8.03 & -128 & 127 & 123 & \mathrm{u}=7 & \$ \text { tube wall }\end{array}$

$\begin{array}{lllllll}29 & 236 & -1.00 & -127 & 123 & \mathrm{u}=7 & \$ \text { central tube }\end{array}$

$\begin{array}{llllllll}31 & 236 & -1.00 & -125 & 128 & 123 & \mathrm{u}=7 & \text { \$ above fuel }\end{array}$

$\begin{array}{lllllll}32 & 20 & -8.03000 & 125 & 122 & -126 \quad \mathrm{u}=7 \quad \text { \$ fuel basket side }\end{array}$

$33 \quad 0 \quad-125122128-123 \quad$ fill $=8 \mathrm{u}=7 \quad \$$ fuel in basket

$\begin{array}{lllll}34 & 236 & -1.000 & 126 & \mathrm{u}=7\end{array}$ \$ outside basket

c fuel and scrap basket stack 


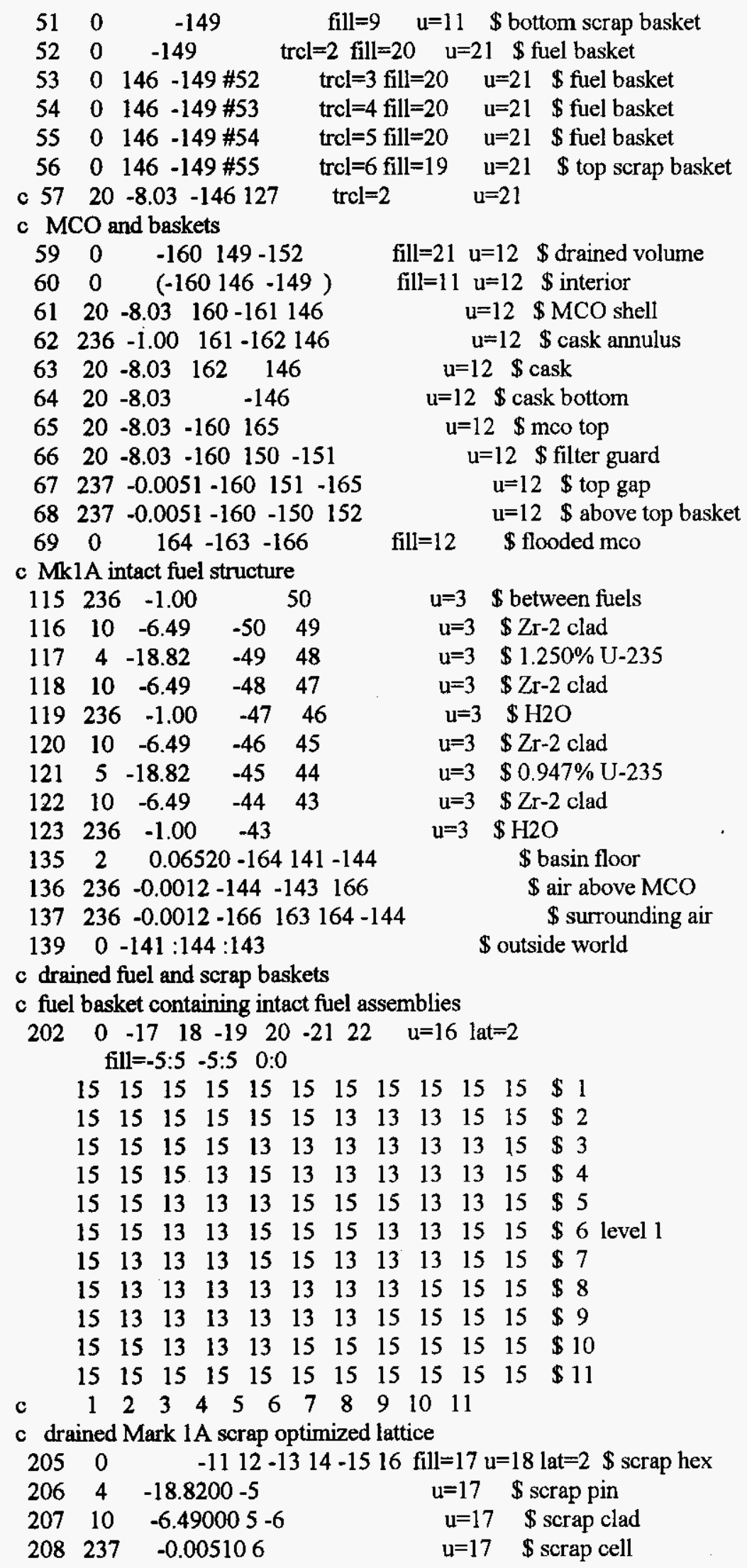


c Drained Scrap basket

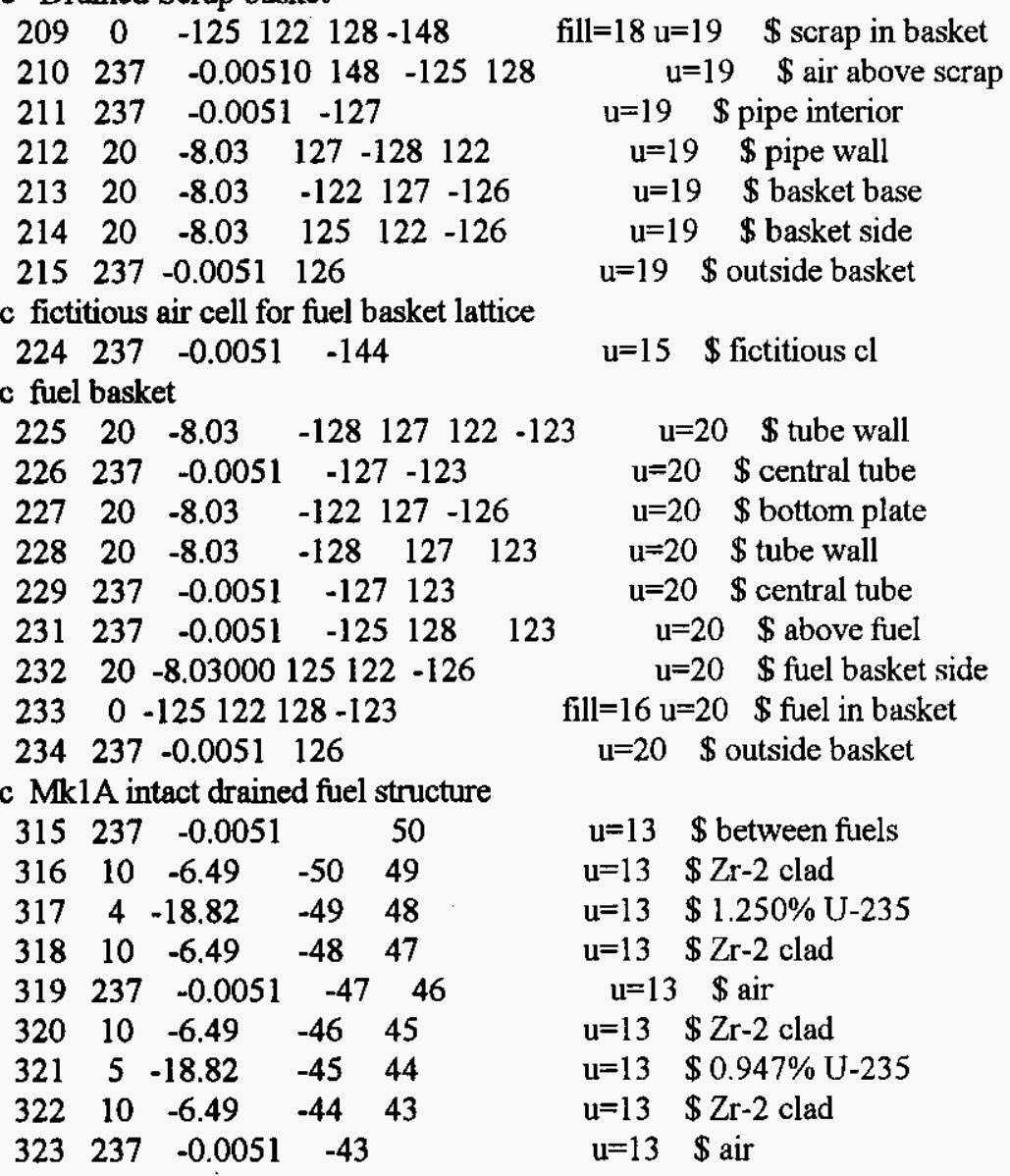

\begin{tabular}{|c|c|c|c|c|c|}
\hline 5 & $\mathrm{cz}$ & 0.6500000 & & & \\
\hline 6 & $\mathrm{cz}$ & 0.7107000 & & & \\
\hline 11 & $\mathrm{p}$ & 0.8660254 & -0.5000000 & 0.0000000 & 1.2013000 \\
\hline 12 & p & 0.8660254 & -0.5000000 & 0.0000000 & -1.2013000 \\
\hline 13 & p & 0.8660254 & 0.5000000 & 0.0000000 & 1.2013000 \\
\hline 14 & $\mathrm{p}$ & 0.8660254 & 0.5000000 & 0.0000000 & -1.2013000 \\
\hline 15 & py & 1.2013000 & & & \\
\hline 16 & py & -1.2013000 & & & \\
\hline 17 & $\mathrm{p}$ & 0.86602540 & $\begin{array}{ll}-0.5 & 0.0\end{array}$ & 3.556 & \\
\hline 18 & $\mathrm{p}$ & 0.86602540 & $\begin{array}{ll}-0.5 & 0.0\end{array}$ & -3.556 & \\
\hline 19 & $\mathrm{p}$ & 0.86602540 & $0.5 \quad 0.0$ & 3.556 & \\
\hline 20 & $\mathrm{p}$ & 0.86602540 & $0.5 \quad 0.0$ & -3.556 & \\
\hline 21 & py & & 3.556 & & \\
\hline 22 & py & & -3.556 & & \\
\hline 43 & cz & 0.5588 & $\$ \mathrm{H} 2 \mathrm{O}$ & & \\
\hline 44 & cz & 0.6223 & $\$ \mathrm{Zr}-2$ clad & & \\
\hline 45 & cz & 1.4808 & $\$$ fuel & & \\
\hline 46 & $\mathrm{cz}$ & 1.5824 & $\$ \mathrm{Zr}-2$ clad & & \\
\hline 47 & cz & 2.2441 & $\$ \mathrm{H} 2 \mathrm{O}$ & & \\
\hline 48 & cz & 2.3076 & $\$ \mathrm{Zr}-2 \mathrm{clad}$ & & \\
\hline 49 & cz & 2.9896 & $\$$ fuel & & \\
\hline 50 & cz & 3.0531 & $\$ \mathrm{Zr}-2$ clad & & \\
\hline 122 & $\mathrm{pz}$ & 0.0000000 & & & \\
\hline
\end{tabular}




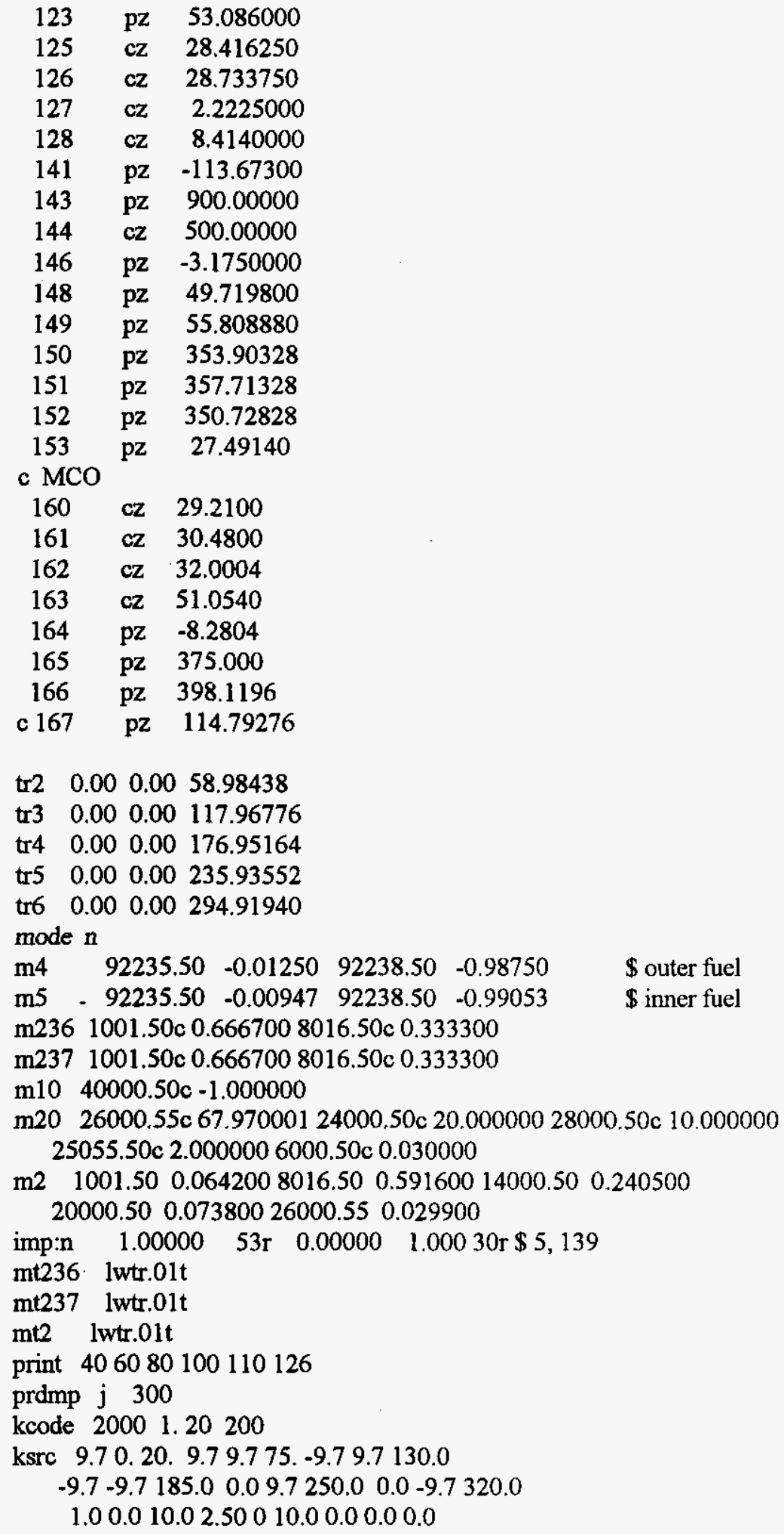




\section{HNF-SD-SNF-CSER-005 REV 5}

\section{F.5 PARTIALLY DRAINED MCO IN THE CVDF CONTAINING MARK IV FUEL AND SCRAP}

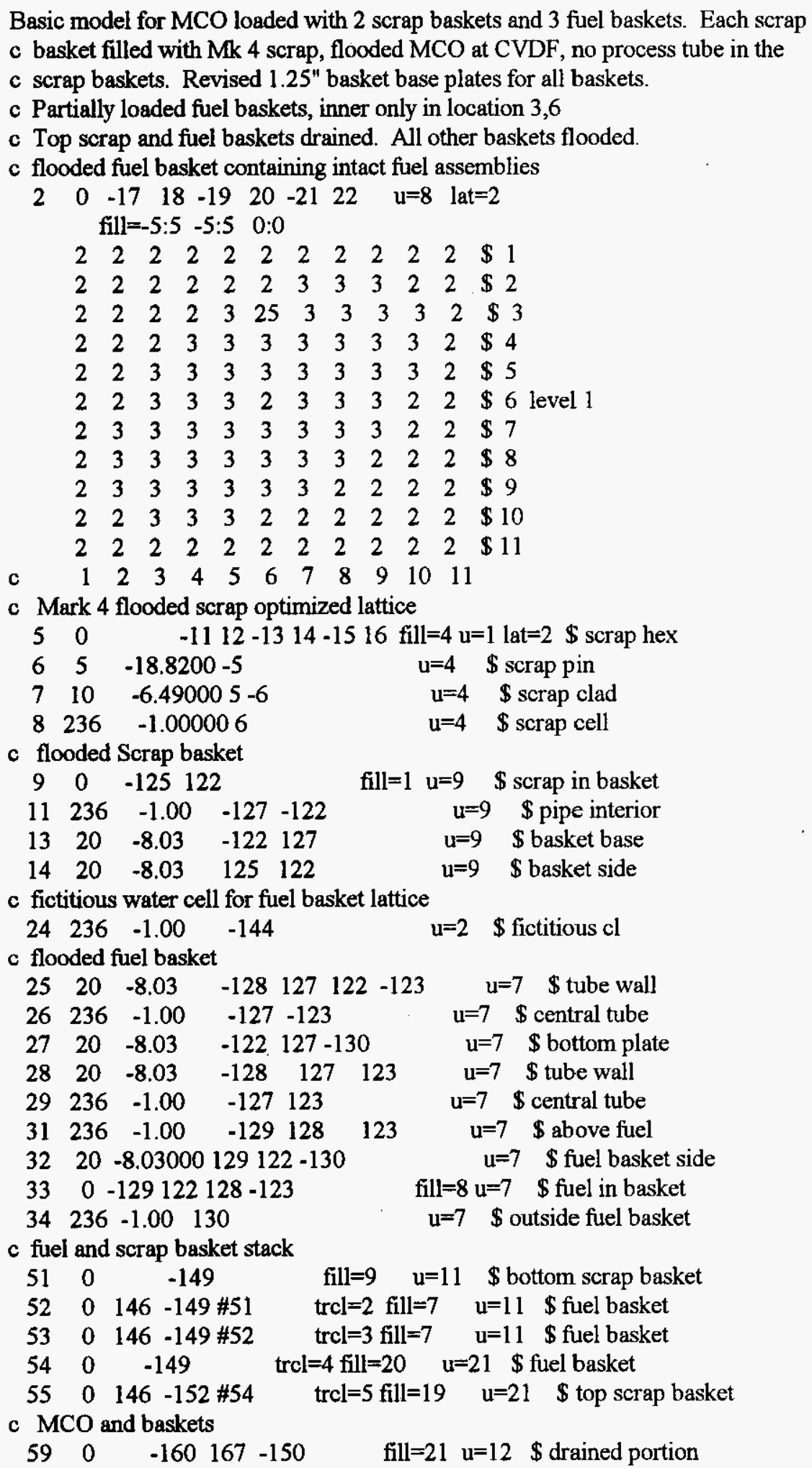




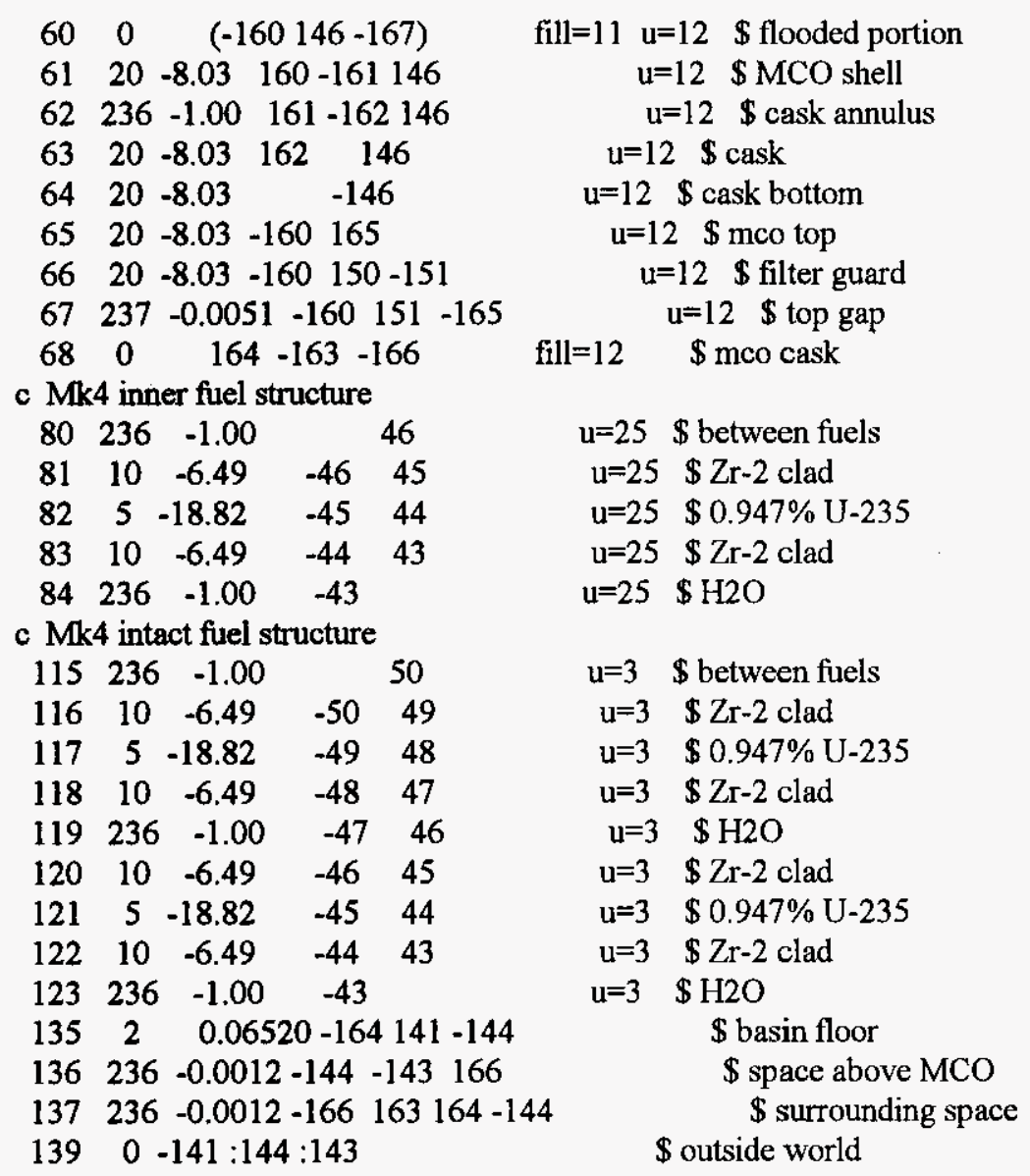

c drained fuel and scrap baskets

c fuel basket containing intact fuel assemblies

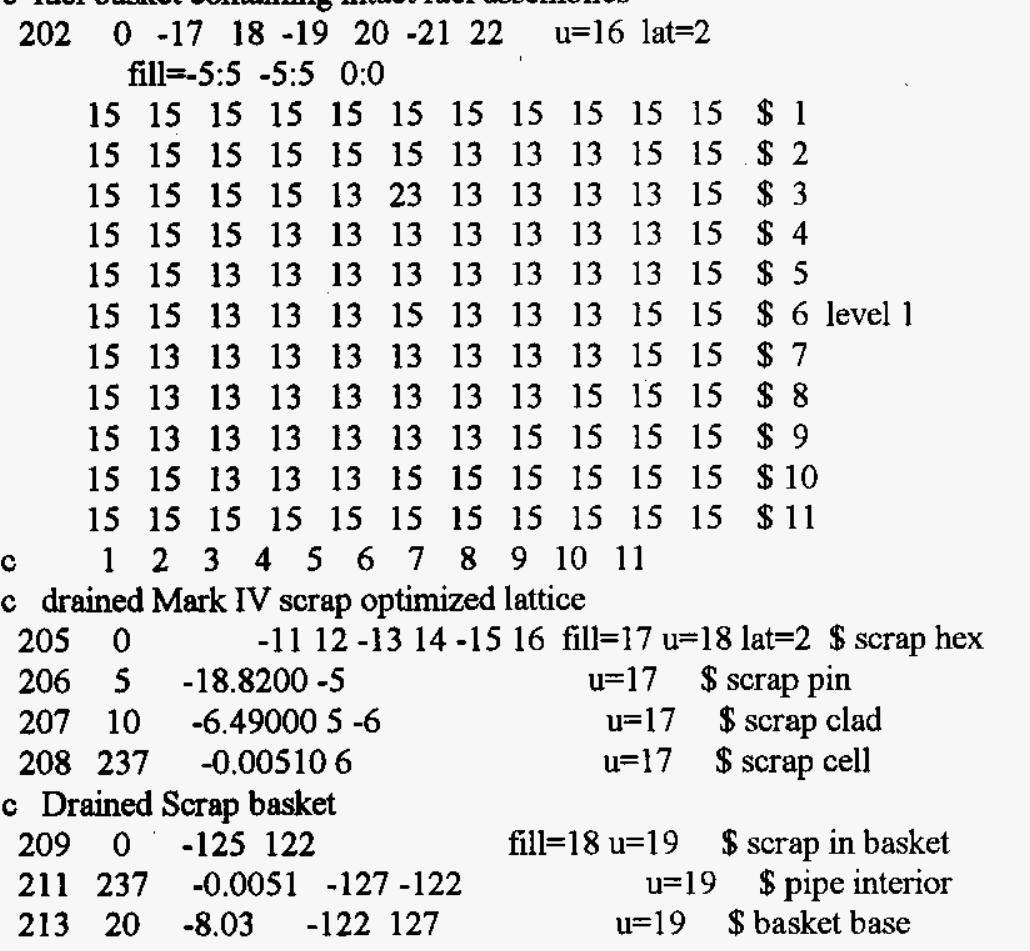


$\begin{array}{lllll}214 & 20 & -8.03 & 125 & 122\end{array}$

c fictitious air cell for fuel basket lattice

$\begin{array}{llll}224 & 237 & -0.0051 & -144\end{array}$

c fuel basket

$\begin{array}{lllllll}225 & 20 & -8.03 & -128 & 127 & 122 & -123\end{array}$

$\begin{array}{lllll}226 & 237 & -0.0051 & -127 & -123\end{array}$

$\begin{array}{llllll}227 & 20 & -8.03 & -122 & 127 & -130\end{array}$

$\begin{array}{llllll}228 & 20 & -8.03 & -128 & 127 & 123\end{array}$

$\begin{array}{lllll}229 & 237 & -0.0051 & -127 & 123\end{array}$

$\begin{array}{llllll}231 & 237 & -0.0051 & -129 & 128 & 123\end{array}$

$\begin{array}{lllllll}232 & 20 & -8.03000 & 129 & 122 & -130\end{array}$

$233 \quad 0 \quad-129 \quad 122 \quad 128-123$

$\begin{array}{llll}234 & 237 & -0.0051 & 130\end{array}$

c MkIV intact drained fuel structure

$\begin{array}{ccccc}315 & 237 & -0.0051 & & 50 \\ 316 & 10 & -6.49 & -50 & 49 \\ 317 & 5 & -18.82 & -49 & 48 \\ 318 & 10 & -6.49 & -48 & 47 \\ 319 & 237 & -0.0051 & -47 & 46 \\ 320 & 10 & -6.49 & -46 & 45 \\ 321 & 5 & -18.82 & -45 & 44 \\ 322 & 10 & -6.49 & -44 & 43 \\ 323 & 237 & -0.0051 & -43 & \end{array}$

c Mk4 drained inner fuel structure

$\begin{array}{lclll}380 & 237 & -0.0051 & 46 \\ 381 & 10 & -6.49 & -46 & 45 \\ 382 & 5 & -18.82 & -45 & 44 \\ 383 & 10 & -6.49 & -44 & 43 \\ 384 & 237 & -0.0051 & -43\end{array}$

$\mathrm{u}=19 \quad \$$ basket side

$\mathrm{u}=15 \quad \$$ fictitious cl

$\mathrm{u}=20 \quad \$$ tube wall

$\mathrm{u}=20 \quad \$$ central tube

$\mathrm{u}=20 \quad \$$ bottom plate

$\mathrm{u}=20 \quad \$$ tube wall

$u=20 \quad \$$ central tube

$\mathrm{u}=20 \quad \$$ above fuel

$\mathrm{u}=20 \quad \$$ fuel basket side

fill $=16 \mathrm{u}=20 \quad \$$ fuel in basket

$\mathrm{u}=20 \quad \$$ outside basket

$\mathrm{u}=13 \quad \$$ between fuels

$\mathrm{u}=13 \quad \$ \mathrm{Zr}-2$ clad

$\mathrm{u}=13 \quad \$ 0.947 \% \mathrm{U}-235$

$\mathrm{u}=13 \quad \$ \mathrm{Zr}-2$ clad

$u=13 \quad \$$ air

$\mathrm{u}=13 \quad \$ \mathrm{Zr}-2$ clad

$\mathrm{u}=13 \quad \$ 0.947 \% \mathrm{U}-235$

$\mathrm{u}=13 \quad \$ \mathrm{Zr}-2$ clad

$\mathrm{u}=13 \quad \$$ air

$\mathrm{u}=23 \quad \$$ between fuels

$\mathrm{u}=23 \quad \$ \mathrm{Zr}-2$ clad

$\mathrm{u}=23 \quad \$ 0.947 \% \mathrm{U}-235$

$\mathrm{u}=23 \quad \$ \mathrm{Zr}-2$ clad

$\mathrm{u}=23 \quad \$ \mathrm{H} 2 \mathrm{O}$

\begin{tabular}{|c|c|c|c|c|c|}
\hline 5 & cz & 0.8000000 & & & \\
\hline 6 & cz & 0.8572000 & & & \\
\hline 11 & $\mathrm{p}$ & 0.8660254 & -0.5000000 & 0.0000000 & 1.3992000 \\
\hline 12 & $\mathrm{p}$ & 0.8660254 & -0.5000000 & 0.0000000 & -1.3992000 \\
\hline 13 & $\mathrm{p}$ & 0.8660254 & 0.5000000 & 0.0000000 & 1.3992000 \\
\hline 14 & $\mathrm{p}$ & 0.8660254 & 0.5000000 & 0.0000000 & -1.3992000 \\
\hline 15 & py & 1.3992000 & & & \\
\hline 16 & py & -1.3992000 & & & \\
\hline 17 & $\mathrm{p}$ & 0.86602540 & $\begin{array}{ll}-0.5 & 0.0\end{array}$ & 3.556 & \\
\hline 18 & $\mathrm{p}$ & 0.86602540 & $\begin{array}{ll}-0.5 & 0.0\end{array}$ & -3.556 & \\
\hline 19 & p & 0.86602540 & $\begin{array}{ll}0.5 & 0.0\end{array}$ & 3.556 & \\
\hline 20 & $\mathrm{p}$ & 0.86602540 & $0.5 \quad 0.0$ & -3.556 & \\
\hline 21 & py & & 3.556 & & \\
\hline 22 & py & & -3.556 & & \\
\hline 43 & $\mathrm{cz}$ & 0.6095 & $\$ \mathrm{H} 2 \mathrm{O}$ & & \\
\hline 44 & cz & 0.6605 & $\$ \mathrm{Zr}-2$ clad & & \\
\hline 45 & cz & 1.5480 & $\$$ fuel & & \\
\hline 46 & $\mathbf{c z}$ & 1.6245 & $\$ \mathrm{Zr}-2$ clad & & \\
\hline 47 & cz & 2.1605 & $\$ \mathrm{H} 2 \mathrm{O}$ & & \\
\hline 48 & cz & 2.2110 & $\$ \mathrm{Zr}-2 \mathrm{clad}$ & & \\
\hline 49 & cz & 3.0165 & $\$$ fuel & & \\
\hline 50 & cz & 3.0800 & $\$ \mathrm{Zr}-2$ clad & & \\
\hline 122 & $\mathrm{pz}$ & 0.0000000 & & & \\
\hline 123 & $\mathrm{pz}$ & 66.294000 & & & \\
\hline
\end{tabular}


c scrap basket side

$125 \quad \mathrm{cz} \quad 28.77001997$

c process tube pipe

$127 \quad \mathrm{cz} \quad 2.2225000$

$128 \mathrm{cz} \quad 3.4925000$

c fuel basket side

$\begin{array}{lll}129 & \mathrm{cz} & 28.41625 \\ 130 & \mathrm{cz} & 28.73375 \\ 141 & \mathrm{pz} & -113.67300 \\ 143 & \mathrm{pz} & 900.00000 \\ 144 & \mathrm{cz} & 500.00000 \\ 146 & \mathrm{pz} & -3.1750000 \\ 149 & \mathrm{pz} & 67.68338 \\ 150 & \mathrm{pz} & 353.83470 \\ 151 & \mathrm{pz} & 357.64470 \\ 152 & \mathrm{pz} & 351.11690 \\ \mathrm{c} \mathrm{MCO} & & \\ 160 & \mathrm{cz} & 29.2100 \\ 161 & \mathrm{cz} & 30.4800 \\ 162 & \mathrm{cz} & 32.0004 \\ 163 & \mathrm{cz} & 51.0540 \\ 164 & \mathrm{pz} & -8.2804 \\ 165 & \mathrm{pz} & 375.000 \\ 166 & \mathrm{pz} & 398.1196 \\ 167 & \mathrm{pz} & 209.40014 \\ & & \end{array}$

tr2 $\quad 0.00 \quad 0.0070 .858380$

$\begin{array}{llll}\text { tr3 } & 0.00 & 0.00 & 141.71676\end{array}$

$\begin{array}{llll}\text { tr4 } & 0.00 & 0.00 & 212.57564\end{array}$

tr5 $0.00 \quad 0.00283 .43352$

mode $\mathrm{n}$

m5 $\quad \begin{array}{lllll}92235.50 & -0.00947 & 92238.50 & -0.99053 \quad \$ \text { inner fuel }\end{array}$

$\mathrm{m} 2361001.50 \mathrm{c} 0.6667008016 .50 \mathrm{c} 0.333300$

$\mathrm{m} 2371001.50 \mathrm{c} 0.6667008016 .50 \mathrm{c} 0.333300$

m10 $40000.50 \mathrm{c}-1.000000$

$\mathrm{m} 2026000.55 \mathrm{c} 67.97000124000 .50 \mathrm{c} 20.00000028000 .50 \mathrm{c} 10.000000$ $25055.50 \mathrm{c} 2.0000006000 .50 \mathrm{c} 0.030000$

m2 $\quad \begin{array}{llllll}1001.50 & 0.064200 & 8016.50 & 0.591600 & 14000.50 & 0.240500\end{array}$

$20000.50 \quad 0.07380026000 .550 .029900$

imp:n $\quad 1.00000 \quad 50 \mathrm{r} \quad 0.000001 .00032 \mathrm{r} \$ 5,139$

$\mathrm{mt236}$ lwtr.01t

mt237 lwtr.01t

mt2 lwtr.01t

print 406080100110126

prdmp j 300

kcode 20001.20200

ksrc 9.70 .20 . $-9.70 .085 .09 .7-9.7150 .0$

$-9.7-9.7250 .0 \quad 0.0-9.7320 .0$

1.00 .010 .02 .50010 .00 .00 .00 .0 
HNF-SD-SNF-CSER-005 REV 5

\section{F.6 18 MARK 1A 26 IN. LONG FUEL ASSEMBLIES IN A MARK IV FUEL BASKET}

Basic model for MCO loaded with 2 scrap baskets and 3 fuel baskets. Each scrap

c basket filled with Mk 4 scrap, flooded MCO at CVDF, no process tube in the

c scrap baskets. Revised 1.25 " basket base plates for all baskets.

c Partially loaded fuel baskets, inner only in location 3,6

c Central fuel basket contains 18 26.1" Mark 1A fuel assemblies

c flooded annulus

c fuel basket containing intact fuel assemblies

$\begin{array}{lllllllllll}2 & 0 & -17 & 18 & -19 & 20 & -21 & 22 & u=8\end{array} \quad$ lat $=2$

fill $=-5: 5 \quad-5: 5 \quad 0: 0$

$\begin{array}{lllllllllllll}2 & 2 & 2 & 2 & 2 & 2 & 2 & 2 & 2 & 2 & 2 & \$ 1 & 1\end{array}$

$\begin{array}{llllllllllll}2 & 2 & 2 & 2 & 2 & 2 & 3 & 3 & 3 & 2 & 2 & \$ 2\end{array}$

$\begin{array}{lllllllllllll}2 & 2 & 2 & 2 & 3 & 15 & 3 & 3 & 3 & 3 & 2 & \$ 3\end{array}$

$\begin{array}{lllllllllllll}2 & 2 & 2 & 3 & 3 & 3 & 3 & 3 & 3 & 3 & 2 & \$ 4 & 4\end{array}$

$\begin{array}{lllllllllllll}2 & 2 & 3 & 3 & 3 & 3 & 3 & 3 & 3 & 3 & 2 & \$ 5\end{array}$

$\begin{array}{lllllllllllll}2 & 2 & 3 & 3 & 3 & 2 & 3 & 3 & 3 & 2 & 2 & \$ 6 & 6 \text { level } 1\end{array}$

$\begin{array}{llllllllllll}2 & 3 & 3 & 3 & 3 & 3 & 3 & 3 & 3 & 2 & 2 & \$ 7\end{array}$

$\begin{array}{lllllllllllll}2 & 3 & 3 & 3 & 3 & 3 & 3 & 3 & 2 & 2 & 2 & \$ 8\end{array}$

$\begin{array}{llllllllllll}2 & 3 & 3 & 3 & 3 & 3 & 3 & 2 & 2 & 2 & 2 & \$ 9\end{array}$

$\begin{array}{llllllllllll}2 & 2 & 3 & 3 & 3 & 2 & 2 & 2 & 2 & 2 & 2 & \$ 10\end{array}$

$\begin{array}{llllllllllll}2 & 2 & 2 & 2 & 2 & 2 & 2 & 2 & 2 & 2 & 2 & \$ 11\end{array}$

$\begin{array}{llllllllllll}c & 1 & 2 & 3 & 4 & 5 & 6 & 7 & 8 & 9 & 10 & 11\end{array}$

c fuel basket containing $18 \mathrm{Mk} 1 \mathrm{~A}$ assemblies

$\begin{array}{llllllllll}3 & 0 & -17 & 18 & -19 & 20 & -21 & 22 & u=21 & \text { lat }=2\end{array}$ fill $=-5: 5 \quad-5: 5 \quad 0: 0$

$\begin{array}{lllllllllllll}2 & 2 & 2 & 2 & 2 & 2 & 2 & 2 & 2 & 2 & 2 & \$ 1\end{array}$

$\begin{array}{llllllllllll}2 & 2 & 2 & 2 & 2 & 2 & 3 & 3 & 3 & 2 & 2 & \$ 2\end{array}$

$\begin{array}{lllllllllllll}2 & 2 & 2 & 2 & 3 & 15 & 3 & 3 & 3 & 3 & 2 & \$ 3\end{array}$

$\begin{array}{lllllllllllll}2 & 2 & 2 & 3 & 3 & 5 & 5 & 3 & 3 & 3 & 2 & \$ 4\end{array}$

$\begin{array}{lllllllllllll}2 & 2 & 3 & 3 & 5 & 5 & 5 & 5 & 3 & 3 & 2 & \$ 5\end{array}$

$\begin{array}{lllllllllllll}2 & 2 & 3 & 5 & 5 & 2 & 5 & 5 & 3 & 2 & 2 & \$ 6 & 6 \text { level } 1\end{array}$

$\begin{array}{llllllllllll}2 & 3 & 3 & 5 & 5 & 5 & 5 & 5 & 3 & 2 & 2 & \$ 7\end{array}$

$\begin{array}{lllllllllllll}2 & 3 & 3 & 3 & 5 & 5 & 5 & 3 & 2 & 2 & 2 & \$ 8\end{array}$

$\begin{array}{lllllllllllll}2 & 3 & 3 & 3 & 3 & 3 & 3 & 2 & 2 & 2 & 2 & \$ 9\end{array}$

$\begin{array}{llllllllllll}2 & 2 & 3 & 3 & 3 & 2 & 2 & 2 & 2 & 2 & 2 & \$ 10\end{array}$

$\begin{array}{lllllllllllll}2 & 2 & 2 & 2 & 2 & 2 & 2 & 2 & 2 & 2 & 2 & \$ 11\end{array}$

$\begin{array}{lllllllllllll}\text { c } & & 1 & 2 & 3 & 4 & 5 & 6 & 7 & 8 & 9 & 10 & 11\end{array}$

c Mark 4 scrap optimized lattice

$50 \quad-1112-1314-1516$ fill=4 u=1 lat=2 \$ scrap hex

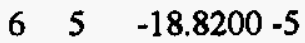

$\begin{array}{llll}7 & 10 & -6.49000 & 5-6\end{array}$

$\mathrm{u}=4 \quad \$$ scrap pin

$u=4 \quad \$$ scrap clad

$8236-1.000006$

$\mathrm{u}=4 \quad \$$ scrap cell

c Scrap basket

$\begin{array}{lllll}9 & 0 & -125 & 122\end{array}$

$\begin{array}{lllll}11 & 236 & -1.00 & -127 & -122\end{array}$

$\begin{array}{lllll}13 & 20 & -8.03 & -122 & 127\end{array}$

$\begin{array}{lllll}14 & 20 & -8.03 & 125 & 122\end{array}$

c MklA intact fuel structure

$\begin{array}{llll}15 & 236 & -1.00 & 30\end{array}$

$\begin{array}{lllll}16 & 10 & -6.49 & -30 & 29\end{array}$

$\begin{array}{lllll}17 & 4 & -18.82 & -29 & 28\end{array}$

$\begin{array}{lllll}18 & 10 & -6.49 & -28 & 27\end{array}$

fill=1 $u=9 \quad \$$ scrap in basket

$\mathrm{u}=9 \quad \$$ pipe interior

$u=9 \quad \$$ basket base

$u=9 \quad \$$ basket side

$\mathrm{u}=5 \quad \$$ between fuels

$\mathrm{u}=5 \quad \$ \mathrm{Zr}-2 \mathrm{clad}$

$\mathrm{u}=5 \quad \$ 1.250 \% \mathrm{U}-235$

$\mathrm{u}=5 \quad \$ \mathrm{Zr}-2 \mathrm{clad}$ 


$\begin{array}{ccccc}19 & 236 & -1.00 & -27 & 26 \\ 20 & 10 & -6.49 & -26 & 25 \\ 21 & 5 & -18.82 & -25 & 24 \\ 22 & 10 & -6.49 & -24 & 23 \\ 23 & 236 & -1.00 & -23 & \end{array}$

c fictitious water cell for fuel basket lattice

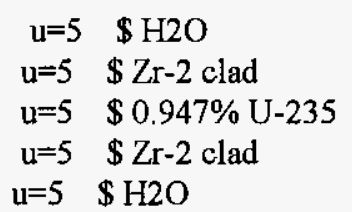

c fuel basket containing Mark $1 \mathrm{~A}$ assemblies

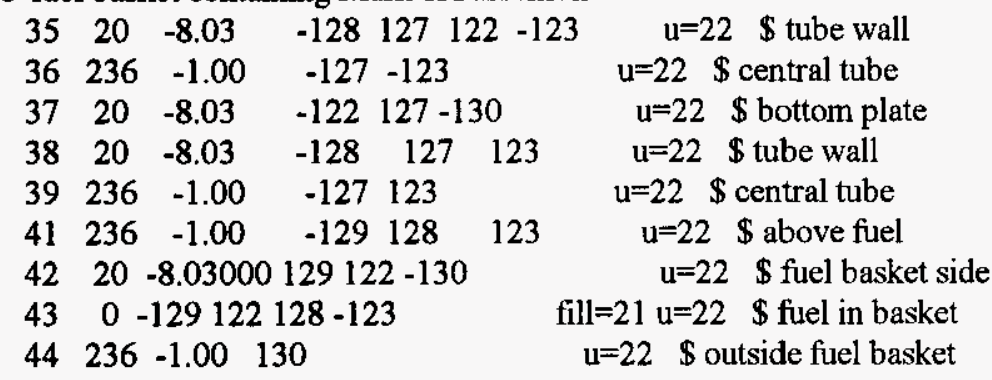

c fuel and scrap basket stack

\begin{tabular}{|c|c|c|c|}
\hline & -149 & fill $=9$ & $\$$ bottom scr \\
\hline 52 & $\begin{array}{llll}0 & 146 & -1\end{array}$ & trcl $=2$ fill $=7$ & $u=11 \$$ fuel basket \\
\hline 5 & $\begin{array}{llll}0 & 146 & -1\end{array}$ & trcl $=3$ fill $=22$ & $u=11 \$$ \\
\hline 5 & $\begin{array}{llll}0 & 146 & -1\end{array}$ & fill $=7$ & $\mathrm{u}=11 \$ \mathrm{f}$ \\
\hline 5 & $0 \quad 146-1$ & $=9$ & $u=11$ \\
\hline & -1.000 & & $=11 \$$ at \\
\hline
\end{tabular}

c MCO and baskets

$60 \quad 0 \quad(-160146-150)$

$\begin{array}{llllll}61 & 20 & -8.03 & 160 & -161 & 146\end{array}$

$\begin{array}{llllll}62 & 236 & -1.00 & 161 & -162 & 146\end{array}$

$\begin{array}{lllll}63 & 20 & -8.03 & 162 & 146\end{array}$

$\begin{array}{llll}64 & 20 & -8.03 & -146\end{array}$

$\begin{array}{lllll}65 & 20 & -8.03 & -160 & 165\end{array}$

$\begin{array}{lllllll}66 & 20 & -8.03 & -160 & 150 & -151\end{array}$

$\begin{array}{llllll}67 & 236 & -1.00 & -160 & 151 & -165\end{array}$

$\begin{array}{lllllll}68 & 0 & 164 & -163 & -166\end{array}$

c Mk4 inner fuel structure

$\begin{array}{llll}80 & 236 & -1.00 & 46\end{array}$

$\begin{array}{lllll}81 & 10 & -6.49 & -46 & 45\end{array}$

$\begin{array}{lllll}82 & 5 & -18.82 & -45 & 44\end{array}$

$\begin{array}{lllll}83 & 10 & -6.49 & -44 & 43\end{array}$

$\begin{array}{llll}84 & 236 & -1.00 & -43\end{array}$

c Mk4 intact fuel structure

$\begin{array}{llll}115 & 236 & -1.00 & 50\end{array}$

$\begin{array}{lllll}116 & 10 & -6.49 & -50 & 49\end{array}$

$\begin{array}{lllll}117 & 5 & -18.82 & -49 & 48\end{array}$

\author{
fill=11 $u=12 \quad \$$ interior \\ $\mathrm{u}=12 \quad \$$ MCO shell \\ $\mathrm{u}=12 \$$ cask annulus \\ $\mathrm{u}=12 \$$ cask \\ $\mathrm{u}=12 \quad \$$ cask bottom \\ $\mathrm{u}=12 \$ \mathrm{mco}$ top \\ $\mathrm{u}=12 \quad \$$ filter guard \\ $u=12 \$$ top gap \\ fill=12 \$ mco cask \\ $\mathrm{u}=15 \quad \$$ between fuels \\ $\mathrm{u}=15 \quad \$ \mathrm{Zr}-2 \mathrm{clad}$ \\ $u=15 \quad \$ 0.947 \%$ U-235 \\ $\mathrm{u}=15 \quad \$ \mathrm{Zr}-2$ clad \\ $\mathrm{u}=15 \$ \mathrm{H} 2 \mathrm{O}$ \\ $\mathrm{u}=3 \quad \$$ between fuels \\ $\mathrm{u}=3 \quad \$ \mathrm{Zr}-2$ clad \\ $\mathrm{u}=3 \quad \$ 0.947 \% \mathrm{U}-235$
}




$$
\begin{aligned}
& \begin{array}{lllll}
118 & 10 & -6.49 & -48 & 47
\end{array} \\
& \begin{array}{lllll}
119 & 236 & -1.00 & -47 & 46
\end{array} \\
& \begin{array}{lllll}
120 & 10 & -6.49 & -46 & 45
\end{array} \\
& \begin{array}{lllll}
121 & 5 & -18.82 & -45 & 44
\end{array} \\
& \begin{array}{lllll}
122 & 10 & -6.49 & -44 & 43
\end{array} \\
& \begin{array}{llll}
123 & 236 & -1.00 & -43
\end{array} \\
& \begin{array}{llllll}
135 & 20 & -8.03 & -164 & 141 & -144
\end{array} \\
& \begin{array}{llllll}
136 & 236 & -0.0012 & -144 & -143 & 166
\end{array} \\
& \begin{array}{lllllll}
137 & 236 & -0.0012 & -166 & 163 & 164 & -144
\end{array} \\
& 139 \quad 0-141: 144: 143
\end{aligned}
$$$$
\begin{array}{lll}
5 & \mathrm{cz} & 0.8000000
\end{array}
$$$$
6 \quad \mathrm{cz} \quad 0.8572000
$$$$
\begin{array}{lll}
11 & \mathrm{p} & 0.8660254
\end{array}
$$$$
12 \quad \mathrm{p} \quad 0.8660254
$$$$
\begin{array}{lll}
13 & \mathrm{p} & 0.8660254
\end{array}
$$$$
14 \quad \mathrm{p} \quad 0.8660254
$$$$
15 \text { py } 1.3992000
$$$$
16 \text { py }-1.3992000
$$$$
\begin{array}{llllll}
17 & \mathrm{p} & 0.86602540 & -0.5 & 0.0 & 3.556
\end{array}
$$$$
\begin{array}{llllll}
18 & \mathrm{p} & 0.86602540 & -0.5 & 0.0 & -3.556
\end{array}
$$$$
\begin{array}{llllll}
19 & \mathrm{p} & 0.86602540 & 0.5 & 0.0 & 3.556
\end{array}
$$$$
\begin{array}{llllll}
20 & \mathrm{p} & 0.86602540 & 0.5 & 0.0 & -3.556
\end{array}
$$$$
21 \text { py }
$$$$
22 \text { py }
$$$$
\text { c Mk } 1 \text { A fuel }
$$$$
\begin{array}{llll}
23 & \mathrm{cz} & 0.5588 & \$ \mathrm{H} 2 \mathrm{O} \\
24 & \mathrm{cz} & 0.6223 & \$ \mathrm{Zr}-2
\end{array}
$$$$
\begin{array}{llll}
25 & \mathrm{cz} & 1.4808 \quad \$ \text { fuel }
\end{array}
$$$$
\begin{array}{llll}
26 & \mathrm{cZ} & 1.5824 & \$ \mathrm{Zr}-2 \mathrm{clad}
\end{array}
$$$$
\begin{array}{llll}
27 & \mathrm{cz} & 2.2441 & \$ \mathrm{H} 2 \mathrm{O}
\end{array}
$$$$
28 \mathrm{cz} \quad 2.3076 \quad \$ \mathrm{Zr}-2 \text { clad }
$$$$
29 \text { cz } 2.9896 \quad \$ \text { fuel }
$$$$
\begin{array}{llll}
30 & \mathrm{cz} & 3.0531 & \$ \mathrm{Zr}-2 \text { clad }
\end{array}
$$

c Mk 4 fuel

$\begin{array}{cccl}43 & \mathrm{cz} & 0.6095 & \text { \$ H2O } \\ 44 & \mathrm{cz} & 0.6605 & \text { \$ Zr-2 clad } \\ 45 & \mathrm{cz} & 1.5480 & \text { \$ fuel } \\ 46 & \mathrm{cz} & 1.6245 & \text { \$ Zr-2 clad } \\ 47 & \mathrm{cz} & 2.1605 & \text { \$ H2O } \\ 48 & \mathrm{cz} & 2.2110 & \text { \$ Zr-2 clad } \\ 49 & \mathrm{cz} & 3.0165 & \text { \$ fuel } \\ 50 & \mathrm{cz} & 3.0800 & \text { \$ Zr-2 clad } \\ 122 & \mathrm{pz} & 0.0000000 & \\ 123 & \mathrm{pz} & 66.294000 & \end{array}$

c scrap basket side
$\begin{array}{lll}125 & \text { cz } & 28.77001997\end{array}$
c $126 \quad$ cz 29.08751997
c process tube pipe
$\begin{array}{rrr}127 & \mathrm{cz} & 2.2225000\end{array}$
$128 \quad \mathrm{cz} \quad 3.4925000$
c fuel basket side
129
cz 28.41625
130
cz 28.73375

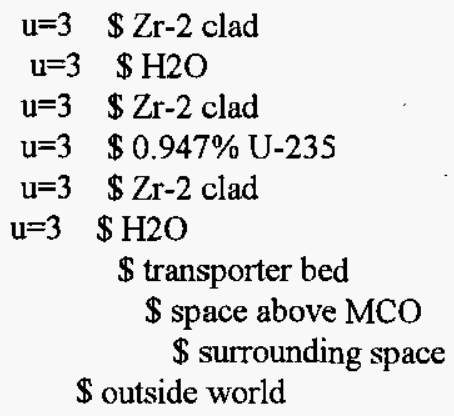

$\mathrm{H} 2 \mathrm{O}$

$\mathrm{r}-2$ clad

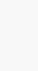

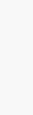




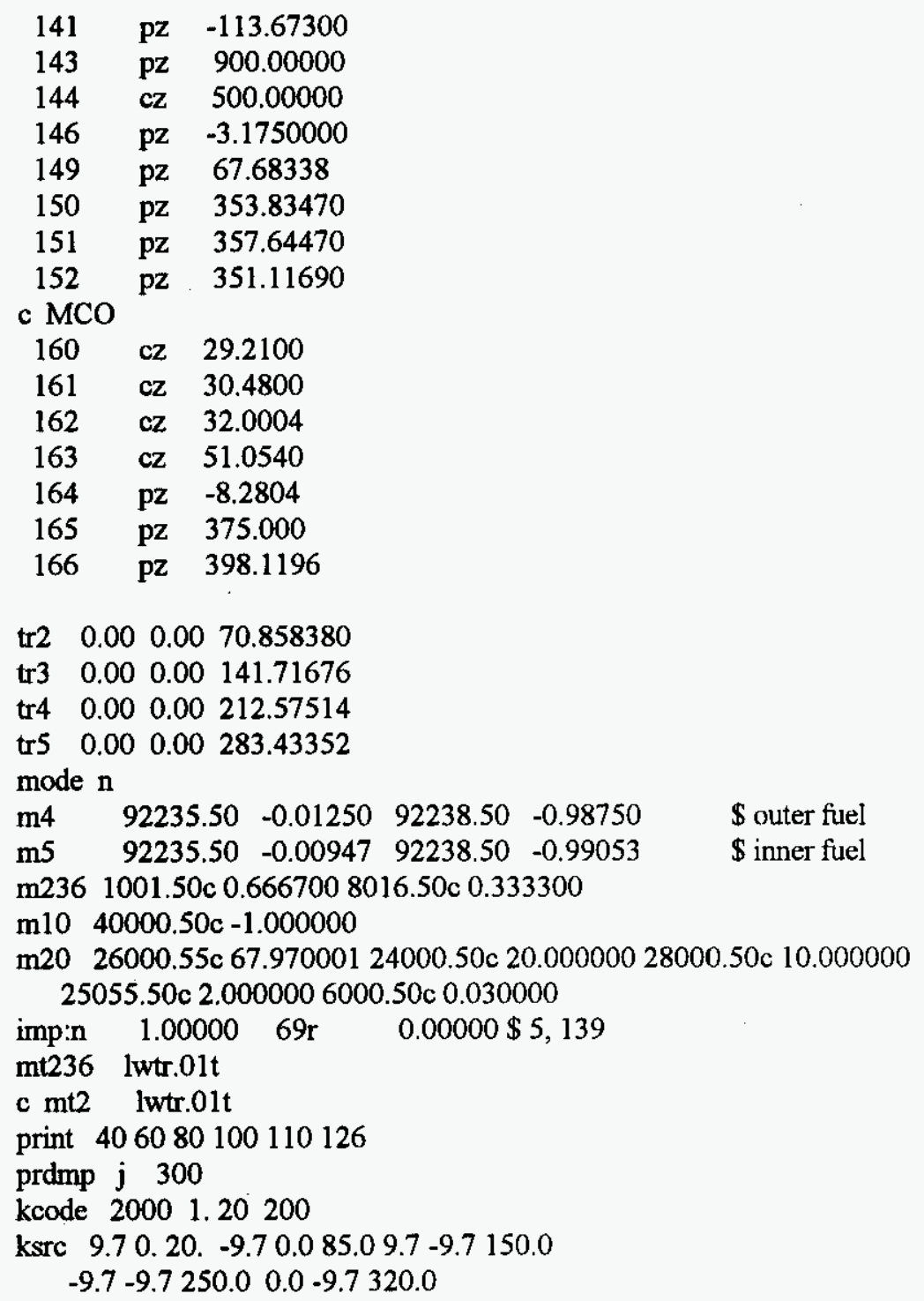




\section{F.7 MARK 1A OUTER FUEL ELEMENTS ONLY LOADED INTO A FUEL BASKET}

Basic model for MCO loaded with 2 scrap baskets and 4 fuel baskets. Each scrap

c basket filled with $575 \mathrm{~kg} \mathrm{Mk} 1 \mathrm{~A}$ scrap, flooded MCO in water

c Partially filled fuel baskets. Revised center post ID

c locations 4,6 and 6,4 containing an outer element only.

c fuel basket containing intact fuel assemblies

$\begin{array}{llllllllll}2 & 0 & -17 & 18 & -19 & 20 & -21 & 22 & \mathrm{u}=8 & \text { lat }=2\end{array}$

fill $=-5: 5 \quad-5: 5 \quad 0: 0$

$\begin{array}{lllllllllllll}2 & 2 & 2 & 2 & 2 & 2 & 2 & 2 & 2 & 2 & 2 & \$ 1 & 1\end{array}$

$\begin{array}{lllllllllllll}2 & 2 & 2 & 2 & 2 & 2 & 3 & 3 & 3 & 2 & 2 & \$ & 2\end{array}$

$\begin{array}{lllllllllllll}2 & 2 & 2 & 2 & 3 & 3 & 3 & 3 & 3 & 3 & 2 & \$ 3 & 3\end{array}$

$\begin{array}{lllllllllllll}2 & 2 & 2 & 3 & 15 & 3 & 3 & 3 & 3 & 3 & 2 & \$ 4\end{array}$

$\begin{array}{lllllllllllll}2 & 2 & 3 & 3 & 3 & 2 & 2 & 3 & 3 & 3 & 2 & \$ 5\end{array}$

$\begin{array}{lllllllllllll}2 & 2 & 3 & 15 & 2 & 2 & 2 & 3 & 3 & 2 & 2 & \$ 6 & 6 \text { level } 1\end{array}$

$\begin{array}{lllllllllllll}2 & 3 & 3 & 3 & 2 & 2 & 3 & 3 & 3 & 2 & 2 & \$ 7\end{array}$

$\begin{array}{lllllllllllll}2 & 3 & 3 & 3 & 3 & 3 & 3 & 3 & 2 & 2 & 2 & \$ 8\end{array}$

$\begin{array}{llllllllllll}2 & 3 & 3 & 3 & 3 & 3 & 3 & 2 & 2 & 2 & 2 & \$ 9\end{array}$

$\begin{array}{llllllllllll}2 & 2 & 3 & 3 & 3 & 2 & 2 & 2 & 2 & 2 & 2 & \$ 10\end{array}$

$\begin{array}{llllllllllll}2 & 2 & 2 & 2 & 2 & 2 & 2 & 2 & 2 & 2 & 2 & \$ 11\end{array}$

$\begin{array}{lllllllllllll}c & 1 & 2 & 3 & 4 & 5 & 6 & 7 & 8 & 9 & 10 & 11\end{array}$

c Mark 1A scrap optimized lattice

$50 \quad-1112-1314-1516$ fill=4 $u=1$ lat=2 \$ scrap hex

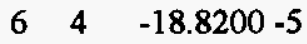

$\begin{array}{lll}7 & 10 & -6.490005-6\end{array}$

$8236-1.000006$

$\mathrm{u}=4 \quad \$$ scrap pin

$\mathrm{u}=4 \quad \$$ scrap clad

$\mathrm{u}=4 \quad \$$ scrap cell

c Scrap basket

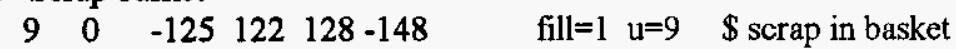

$\begin{array}{llllllll}10 & 236 & -1.00000 & 148 & -125 & 128 & \mathrm{u}=9 & \$ \text { w water above scrap }\end{array}$

$\begin{array}{llllll}11 & 236 & -1.00 & -127 \quad \mathrm{u}=9 \quad \text { \$ pipe interior }\end{array}$

$\begin{array}{llllllll}12 & 20 & -8.03 & 127 & -128 & 122 & u=9 & \$ \text { pipe wall }\end{array}$

$\begin{array}{lllllll}13 & 20 & -8.03 & -122 & 127 & u=9 & \$ \text { basket base }\end{array}$

$\begin{array}{lllllll}14 & 20 & -8.03 & 125 & 122 & u=9 & \$ \text { basket side }\end{array}$

c fictitious water cell for fuel basket lattice

$\begin{array}{llllll}24 & 236 & -1.00 & -144 & \mathrm{u}=2 & \$ \text { fictitious cl }\end{array}$

c fuel basket

$\begin{array}{lllllllll}25 & 20 & -8.03 & -128 & 127 & 122 & -123 & \mathrm{u}=7 & \$ \text { tube wall }\end{array}$

$\begin{array}{lllllll}26 & 236 & -1.00 & -127 & -123 & \mathrm{u}=7 & \$ \text { central tube }\end{array}$

$\begin{array}{lllll}27 & 20 & -8.03 & -122 & 127\end{array}$

$\begin{array}{llllll}28 & 20 & -8.03 & -128 & 127 & 123\end{array}$

$\begin{array}{lllll}29 & 236 & -1.00 & -127 & 123\end{array}$

$\begin{array}{lllll}31 & 236 & -1.00 & -125 & 128\end{array}$

$\mathrm{u}=7 \quad \$$ central tube

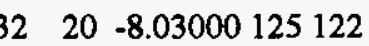

$33 \quad 0-125122128-123$

c fuel and scrap basket stack

$\begin{array}{llllll}51 & 0 & -149 \quad \text { fill }=9 \quad \mathrm{u}=11 \quad \text { \$ bottom scrap basket }\end{array}$

$52 \quad 0 \quad 146 \quad-149 \# 51 \quad$ trcl=2 fill=7 $u=11 \quad \$$ fuel basket

$53 \quad 0 \quad 146-149 \# 52 \quad$ trcl=3 fill=7 $\quad u=11 \quad$ \& fuel basket

$54 \quad 0 \quad 146 \quad-149 \# 53 \quad$ trcl=4 fill=7 $u=11 \quad \$$ fuel basket

$55 \quad 0 \quad 146-149 \# 54 \quad$ trcl=5 fill=7 $\quad u=11 \quad \$$ fuel basket

$56 \quad 0 \quad 146 \quad-149 \# 55 \quad$ trcl=6 fill=9 $u=11 \quad \$$ top scrap basket

c $\mathrm{MCO}$ and baskets

$60236-1.000(-160146-152)(-126:-152)$ fill=11 $u=12 \quad \$$ interior 


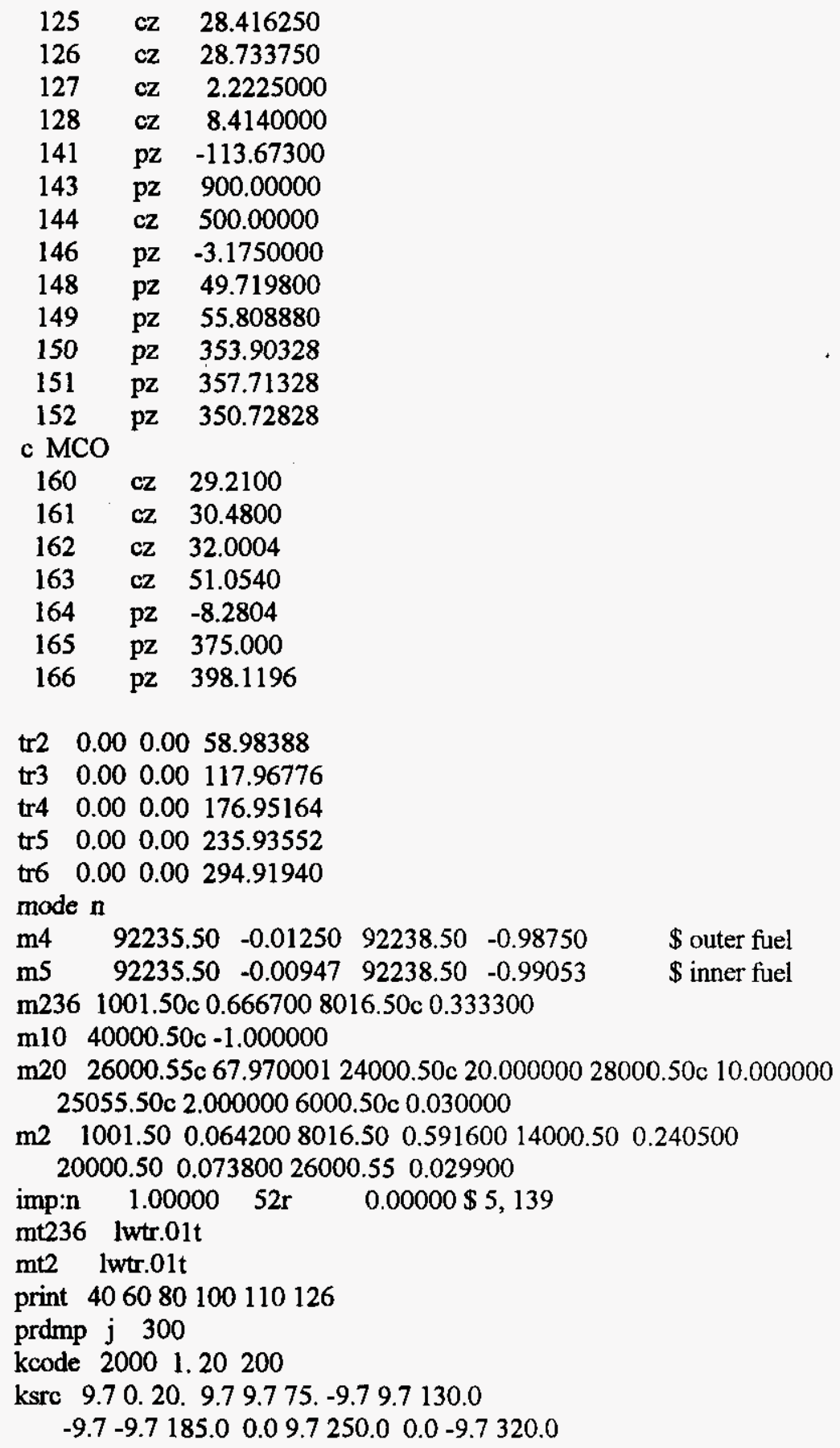




\section{F.8 MARK 1A DROP MODEL}

Basic model for MCO loaded with 6 fuel baskets in a flooded MCO.

c revised center pipe with $1.75^{n} \mathrm{ID}$. Drop model with fuel rubbilized

c and the basket sides destroyed. Spacing maintained by safety class

c central pipe and basket bases.

c Mark 1A fuel rubble optimized lattice

$150 \quad-11 \quad 12-13 \quad 14-15 \quad 16$ fill=3 u=8 lat=2 \$ scrap hex

$16 \quad 6 \quad-18.8200-5 \quad u=3 \quad \$$ scrap pin

$\begin{array}{llll}17 & 10 & -6.490005-6 & \mathrm{u}=3 \quad \text { \$ scrap clad }\end{array}$

$18236 \quad-1.000006 \quad u=3 \quad$ \$ scrap cell

c fuel basket with rubble
$\begin{array}{llllll}25 & 20 & -8.03 & -128 & 127 & 122\end{array}$
$\begin{array}{llll}26 & 236 & -1.00 & -127\end{array}$
$\begin{array}{lllll}27 & 20 & -8.03 & -122 & 127\end{array}$
$\begin{array}{lll}33 & 0 & 122 \\ 128\end{array}$
$\mathrm{u}=7 \quad \$$ tube wall
$\mathrm{u}=7 \quad \$$ central tube
$\mathrm{u}=7 \quad \$$ bottom plate
fill=8 $u=7 \quad \$$ fuel in basket

c fuel and scrap basket stack
$\begin{array}{llll}51 & 0 & -149\end{array}$
$52 \quad 0 \quad 146-149$ \#51
$53 \quad 0 \quad 146-149 \# 52$
$\begin{array}{lllll}54 & 0 & 146 & -149 & \# 53\end{array}$
$\begin{array}{lllll}55 & 0 & 146 & -149 & \# 54\end{array}$
$\begin{array}{llll}56 & 0 & 146 & -149\end{array}$
fill=7 $\quad \mathrm{u}=11 \quad \$$ bottom fuel basket
trcl=2 fill=7 u=11 $\$$ fuel basket
trcl=3 fill=7 $u=11 \quad \$$ fuel basket
trcl=4 fill=7 u=11 \$ fuel basket
trcl=5 fill=7 $u=11 \quad \$$ fuel basket

c MCO and baskets

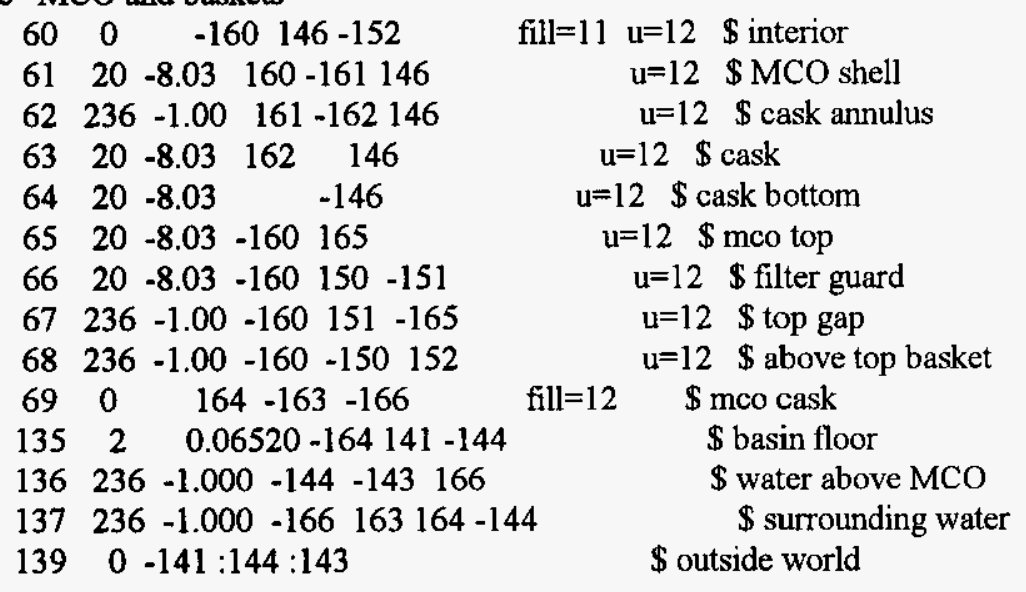

$\begin{array}{ccrrrr}5 & \mathrm{cz} & 0.6500000 & & & \\ 6 & \mathrm{cz} & 0.7107000 & & & \\ 11 & \mathrm{p} & 0.8660254 & -0.5000000 & 0.0000000 & 1.2013000 \\ 12 & \mathrm{p} & 0.8660254 & -0.5000000 & 0.0000000 & -1.2013000 \\ 13 & \mathrm{p} & 0.8660254 & 0.5000000 & 0.0000000 & 1.2013000 \\ 14 & \mathrm{p} & 0.8660254 & 0.5000000 & 0.0000000 & -1.2013000 \\ 15 & \mathrm{py} & 1.2013000 & & & \\ 16 & \mathrm{py} & -1.2013000 & & & \\ 122 & \mathrm{pz} & 0.0000000 & & & \\ 127 & \mathrm{cz} & 2.2225000 & & & \\ 128 & \mathrm{cz} & 8.4140000 & & & \\ 141 & \mathrm{pz} & -113.67300 & & & \\ 143 & \mathrm{pz} & 900.00000 & & & \\ 144 & \mathrm{cz} & 500.00000 & & & \\ & & & & & \end{array}$


HNF-SD-SNF-CSER-005 REV 5

$\begin{array}{ccc}146 & \text { pz } & -3.1750000 \\ 149 & \text { pz } & 55.808880 \\ 150 & \mathrm{pz} & 353.90328 \\ 151 & \mathrm{pz} & 357.71328 \\ 152 & \mathrm{pz} & 350.72828 \\ \mathrm{c} \mathrm{MCO} & & \\ 160 & \mathrm{cz} & 29.2100 \\ 161 & \mathrm{cz} & 30.4800 \\ 162 & \mathrm{cz} & 32.0004 \\ 163 & \mathrm{cz} & 51.0540 \\ 164 & \mathrm{pz} & -8.2804 \\ 165 & \mathrm{pz} & 375.000 \\ 166 & \mathrm{pz} & 398.1196\end{array}$

tr2 $0.00 \quad 0.00 \quad 58.98388$

$\begin{array}{lllll}\text { tr3 } & 0.00 & 0.00 & 117.96776\end{array}$

$\begin{array}{lllllll}\text { tr4 } & 0.00 & 0.00 & 176.95164\end{array}$

$\begin{array}{lllll}\text { tr5 } & 0.00 & 0.00 & 235.93552\end{array}$

tr6 $\quad 0.00 \quad 0.00 \quad 294.91940$

mode $\mathrm{n}$

$\begin{array}{llllll}\text { m4 } & 92235.50 & -0.01250 & 92238.50 & -0.98750 \quad \text { \$ outer fuel }\end{array}$

m6 $\quad 92235.50 \quad-0.01150 \quad 92238.50 \quad-0.98850 \quad$ \$ mixed rubble

$\mathrm{m} 2361001.50 \mathrm{c} 0.6667008016 .50 \mathrm{c} 0.333300$

$\mathrm{m} 10 \quad 40000.50 \mathrm{c}-1.000000$

m20 26000.55c 67.970001 24000.50c $20.00000028000 .50 \mathrm{c} 10.000000$

$25055.50 \mathrm{c} 2.0000006000 .50 \mathrm{c} 0.030000$

$\begin{array}{lllllll}\mathrm{m} 2 & 1001.50 & 0.064200 & 8016.50 & 0.591600 & 14000.50 & 0.240500\end{array}$

$20000.50 \quad 0.07380026000 .55 \quad 0.029900$

$\begin{array}{llll}\text { imp:n } \quad 1.00000 \quad 26 r & 0.00000 \$ 5,139\end{array}$

mt236 lwtr.01t

print 406080100110126

prdmp j 300

kcode 20001.20200

ksrc 9.70 .20 . 


\section{F.9 MARK IV DROP MODEL}

Vertical drop model for a mark $4 \mathrm{MCO}$.

c The MCO is filled with optimized scrap to the filter guard.

c Basket bases included, small pipe region filled with scrap

c Mark 4 scrap optimized lattice
50
$-1112-1314-1516$ fill=4 u=1 lat=2 \$ scrap hex

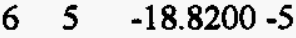
$\begin{array}{llll}7 & 10 & -6.490005 & -6\end{array}$
$\mathrm{u}=4 \quad \$$ scrap pin
$\mathrm{u}=4 \quad \$$ scrap clad
$8236-1.000006$
$\mathrm{u}=4 \quad \$$ scrap cell

c Scrap basket
$\begin{array}{lll}9 & 0 & 122\end{array}$
fill=1 $u=9 \quad \$$ scrap in basket
$\begin{array}{llll}11 & 0 & -127 & -122\end{array}$
$\begin{array}{lllll}13 & 20 & -8.03 & -122 & 127\end{array}$
fill $=1 \quad u=9 \quad \$$ pipe interior
$\mathrm{u}=9 \quad \$$ basket base

c fuel basket containing rubbilized fuel material

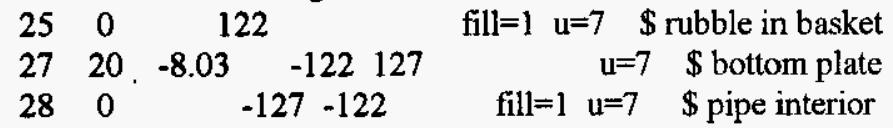

c fuel and scrap basket stack

$\begin{array}{ccccccc}51 & 0 & -149 & \text { fill=9 } u=11 & \$ \text { bottom scrap basket } \\ 52 & 0 & 146 & -149 \# 51 & \text { trcl=2 fill=7 } & u=11 & \$ \text { fuel basket } \\ 53 & 0 & 146 & -149 \# 52 & \text { trcl=3 fill=7 } & u=11 & \$ \text { fuel basket } \\ 54 & 0 & 146 & -149 \# 53 & \text { trcl=4 fill=7 } & u=11 & \$ \text { fuel basket } \\ 55 & 0 & 146 & -149 \# 54 & \text { trcl=5 fill=9 } & u=11 & \$ \text { top scrap basket } \\ 59 & 0 & 152 \# 55 & \text { fill=1 } & u=11 & \$ \text { top of top basket }\end{array}$

c $\mathrm{MCO}$

$\begin{array}{lllll}61 & 20 & -8.03 & 160 & -161\end{array}$

$\begin{array}{lllll}62 & 236 & -1.00 & 161 & -162\end{array}$

$\mathrm{u}=12 \$ \mathrm{MCO}$ shell

$\mathrm{u}=12 \$$ cask annulus

$\begin{array}{lllll}63 & 20 & -8.03 & 162\end{array}$

$\begin{array}{lllll}64 & 20 & -8.03 & -160 & -146\end{array}$

$\mathrm{u}=12 \quad \$$ cask

$\mathrm{u}=12 \$$ cask bottom

$\mathrm{u}=12 \$$ mco top

$\mathrm{u}=12 \$$ filter guard

$\begin{array}{llllll}66 & 20 & -8.03 & -160 & 150 & -151\end{array}$

$\begin{array}{llllll}67 & 236 & -1.00 & -160 & 151 & -165\end{array}$

$\begin{array}{lllllll}68 & 0 & 164 & -163 & -166\end{array}$

$\mathrm{u}=12 \$$ top gap

$\begin{array}{lll}135 & 2 & 0.06520-164141-144\end{array}$

$136 \quad 236-1.000-144-143 \quad 166$

$\begin{array}{lllllll}137 & 236 & -1.000 & -166 & 163 & 164 & -144\end{array}$

$139 \quad 0-141: 144: 143$

fill $=12 \quad \$$ mco cask

$\$$ basin floor

$\$$ water above $\mathrm{MCO}$

$\$$ surrounding water

$\$$ outside world

$\begin{array}{ccrcrr}5 & \mathrm{cz} & 0.8000000 & & & \\ 6 & \mathrm{cz} & 0.8572000 & & & \\ 11 & \mathrm{p} & 0.8660254 & -0.5000000 & 0.0000000 & 1.3992000 \\ 12 & \mathrm{p} & 0.8660254 & -0.5000000 & 0.0000000 & -1.3992000 \\ 13 & \mathrm{p} & 0.8660254 & 0.5000000 & 0.0000000 & 1.3992000 \\ 14 & \mathrm{p} & 0.8660254 & 0.5000000 & 0.0000000 & -1.3992000 \\ 15 & \mathrm{py} & 1.3992000 & & & \\ 16 & \mathrm{py} & -1.3992000 & & & \\ 122 & \mathrm{pz} & 0.0000000 & & & \\ 127 & \mathrm{cz} & 2.2225000 & & & \\ 141 & \mathrm{pz} & -113.67300 & & & \\ 143 & \mathrm{pz} & 900.00000 & & & \\ 144 & \mathrm{cz} & 500.00000 & & & \end{array}$




$$
\begin{array}{lll}
146 & \mathrm{pz} & -3.1750000 \\
149 & \mathrm{pz} & 67.68338 \\
150 & \mathrm{pz} & 353.83470 \\
151 & \mathrm{pz} & 357.64470 \\
152 & \mathrm{pz} & 351.11690 \\
\mathrm{c} \mathrm{MCO} & & \\
160 & \mathrm{cz} & 29.2100 \\
161 & \mathrm{cz} & 30.4800 \\
162 & \mathrm{cz} & 32.0004 \\
163 & \mathrm{cz} & 51.0540 \\
164 & \mathrm{pz} & -8.2804 \\
165 & \mathrm{pz} & 375.000 \\
166 & \mathrm{pz} & 398.1196
\end{array}
$$

tr2 $\quad 0.00 \quad 0.00 \quad 70.858380$

$\begin{array}{lllll}\text { tr3 } & 0.00 & 0.00 & 141.71676\end{array}$

$\begin{array}{lllll}\text { tr4 } & 0.00 & 0.00 & 212.57514\end{array}$

tr5 $0.00 \quad 0.00283 .43352$

mode $n$

$\begin{array}{llllll}\text { m5 } & 92235.50 & -0.00947 & 92238.50 & -0.99053 & \text { \$ inner fuel }\end{array}$

$\mathrm{m} 2361001.50 \mathrm{c} 0.6667008016 .50 \mathrm{c} 0.333300$

$\mathrm{m} 10 \quad 40000.50 \mathrm{c}-1.000000$

$\mathrm{m} 2026000.55 \mathrm{c} 67.97000124000 .50 \mathrm{c} 20.00000028000 .50 \mathrm{c} 10.000000$

$25055.50 \mathrm{c} 2.0000006000 .50 \mathrm{c} 0.030000$

$\begin{array}{lllllll}\mathrm{m} 2 & 1001.50 & 0.064200 & 8016.50 & 0.591600 & 14000.50 & 0.240500\end{array}$

$20000.50 \quad 0.07380026000 .550 .029900$

imp:n $\quad 1.00000 \quad 27 \mathrm{r} \quad 0.00000 \$ 5,139$

mt236 lwtr.01t

print 406080100110126

prdmp j 300

kcode 20001.20400

ksrc 9.70 .20 . 


\section{F.10 CSB MODEL}

Basic model for the CSB. Each MCO loaded with 2 scrap and 4 fuel baskets. c Each scrap basket filled with Mk 1A scrap. Vault surrounded by concrete. c empty location 4,5 in the fuel baskets. Revised center post ID

c fuel basket containing intact fuel assemblies

$\begin{array}{llllllllll}2 & 0 & -17 & 18 & -19 & 20 & -21 & 22 & \mathrm{u}=8 & \mathrm{lat}=2\end{array}$

fill $=-5: 5 \quad-5: 5 \quad 0: 0$

$\begin{array}{lllllllllllll}5 & 5 & 5 & 5 & 5 & 5 & 5 & 5 & 5 & 5 & 5 & \$ & 1\end{array}$

$\begin{array}{lllllllllllll}5 & 5 & 5 & 5 & 5 & 5 & 3 & 3 & 3 & 5 & 5 & \$ 2 & 2\end{array}$

$\begin{array}{lllllllllllll}5 & 5 & 5 & 5 & 3 & 3 & 3 & 3 & 3 & 3 & 5 & \$ 3 & 3\end{array}$

$\begin{array}{lllllllllllll}5 & 5 & 5 & 3 & 5 & 3 & 3 & 3 & 3 & 3 & 5 & \$ 4 & 4\end{array}$

$\begin{array}{lllllllllllll}5 & 5 & 3 & 3 & 3 & 5 & 5 & 3 & 3 & 3 & 5 & \$ 5\end{array}$

$\begin{array}{lllllllllllll}5 & 5 & 3 & 3 & 5 & 5 & 5 & 3 & 3 & 5 & 5 & \$ 6 & 6 \text { level } 1\end{array}$

$\begin{array}{lllllllllllll}5 & 3 & 3 & 3 & 5 & 5 & 3 & 3 & 3 & 5 & 5 & \$ 7\end{array}$

$\begin{array}{lllllllllllll}5 & 3 & 3 & 3 & 3 & 3 & 3 & 3 & 5 & 5 & 5 & \$ 8\end{array}$

$\begin{array}{lllllllllllll}5 & 3 & 3 & 3 & 3 & 3 & 3 & 5 & 5 & 5 & 5 & \$ 9 & 9\end{array}$

$\begin{array}{llllllllllll}5 & 5 & 3 & 3 & 3 & 5 & 5 & 5 & 5 & 5 & 5 & \$ 10\end{array}$

$\begin{array}{llllllllllll}5 & 5 & 5 & 5 & 5 & 5 & 5 & 5 & 5 & 5 & 5 & \$ 11\end{array}$

$\begin{array}{lllllllllllll}\text { c } & & 1 & 2 & 3 & 4 & 5 & 6 & 7 & 8 & 9 & 10 & 11\end{array}$

c Mark 1A scrap optimized lattice

$50 \quad-11 \quad 12-13 \quad 14-1516$ fill=4 $u=1$ lat=2 $\$$ scrap hex

$\begin{array}{lllll}6 & 4 & -18.8200-5 & \mathrm{u}=4 \quad \$ \text { scrap pin }\end{array}$

$\begin{array}{lllll}7 & 10 & -6.490005-6 & \mathrm{u}=4 & \$ \text { scrap clad }\end{array}$

$8236-0.005106 \quad u=4 \quad \$$ scrap cell

c Scrap basket

$\begin{array}{llllll}9 & 0 & -125 & 122 & 128 & -148 \quad \text { fill }=1 \quad u=9 \quad \$ \text { scrap in basket }\end{array}$

$\begin{array}{lllllllll}10 & 236 & -0.00510 & 148 & -125 & 128 & u=9 & \$ \text { vapor above scrap }\end{array}$

$\begin{array}{llll}11 & 236 & -0.0051 & -127\end{array}$

$\begin{array}{llllll}12 & 20 & -8.03 & 127 & -128 & 122\end{array}$

$\begin{array}{lllllll}13 & 20 & -8.03 & -122 & 127 & -126\end{array}$

$\begin{array}{llllll}14 & 20 & -8.03 & 125 & 122 & -126\end{array}$

$\begin{array}{llll}15 & 236 & -0.0051 & 126\end{array}$

$\mathrm{u}=9 \quad \$$ pipe interior

$\mathrm{u}=9 \quad \$$ pipe wall

$\mathrm{u}=9 \quad \$$ basket base

u=9 $\$$ basket side

c fictitious cell for fuel basket lattice

$$
\begin{array}{lllll}
24 & 236 & -0.0051 & -144 & \mathrm{u}=5
\end{array} \quad \text { fictitious } \mathrm{cl}
$$

$u=9 \quad \$$ outside basket

c fuel basket

$$
\begin{array}{lllllll}
25 & 20 & -8.03 & -128 & 127 & 122 & -123
\end{array}
$$

$\begin{array}{lllll}26 & 236 & -0.0051 & -127 & -123\end{array}$

$\begin{array}{llllll}27 & 20 & -8.03 & -122 & 127 & -126\end{array}$

$\begin{array}{llllll}28 & 20 & -8.03 & -128 & 127 & 123\end{array}$

$\begin{array}{lllll}29 & 236 & -0.0051 & -127 & 123\end{array}$

$\begin{array}{lllll}31 & 236 & -0.0051 & -125 & 128\end{array}$

$\begin{array}{llllll}32 & 20 & -8.03000 & 125 & 122 & -126\end{array}$

$\begin{array}{llllll}33 & 0 & -125 & 122 & 128 & -123\end{array}$

$34 \quad 236-0.0051 \quad 126$

c fuel and scrap basket stack
$\begin{array}{lll}51 & 0 & -149\end{array}$
$\begin{array}{lllll}52 & 0 & 146 & -149 & \# 51\end{array}$
$\begin{array}{lllll}53 & 0 & 146 & -149 & \# 52\end{array}$
$\begin{array}{lllll}54 & 0 & 146 & -149 & \# 53\end{array}$
$\begin{array}{lllll}55 & 0 & 146 & -149 & \# 54\end{array}$
$\begin{array}{lllll}56 & 0 & 146 & -149 & \# 55\end{array}$
fill=9 $\quad u=11 \quad \$$ bottom scrap basket
trcl=2 fill=7 $u=11 \quad \$$ fuel basket
trcl=3 fill=7 $u=11 \quad \$$ fuel basket
trcl=4 fill=7 $u=11 \quad \$$ fuel basket
trcl=5 fill=7 u=11 \$ fuel basket
trcl=6 fill=9 $\quad u=11 \quad \$$ top scrap basket

$\mathrm{u}=7 \quad \$$ tube wall

$\mathrm{u}=7 \quad \$$ central tube

$\mathrm{u}=7 \quad \$$ bottom plate

$\mathrm{u}=7 \quad \$$ tube wall

$u=7 \quad \$$ central tube

$u=7 \quad \$$ above fuel

$u=7 \quad \$$ fuel basket side

fill=8 $u=7 \quad \$$ fuel in basket

$\mathrm{u}=7 \quad \$$ outside basket

c MCO and baskets 


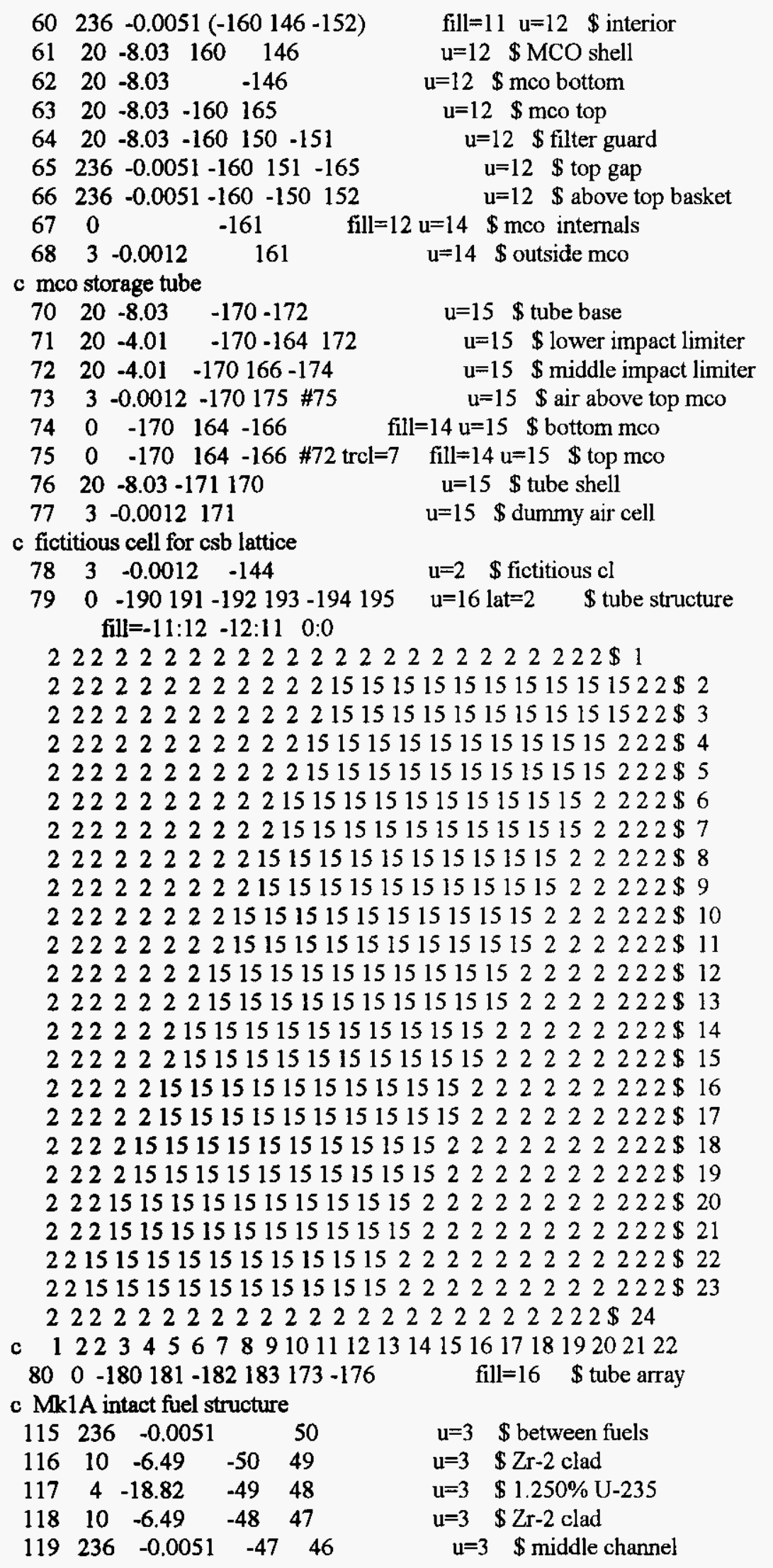




\section{HNF-SD-SNF-CSER-005 REV 5}

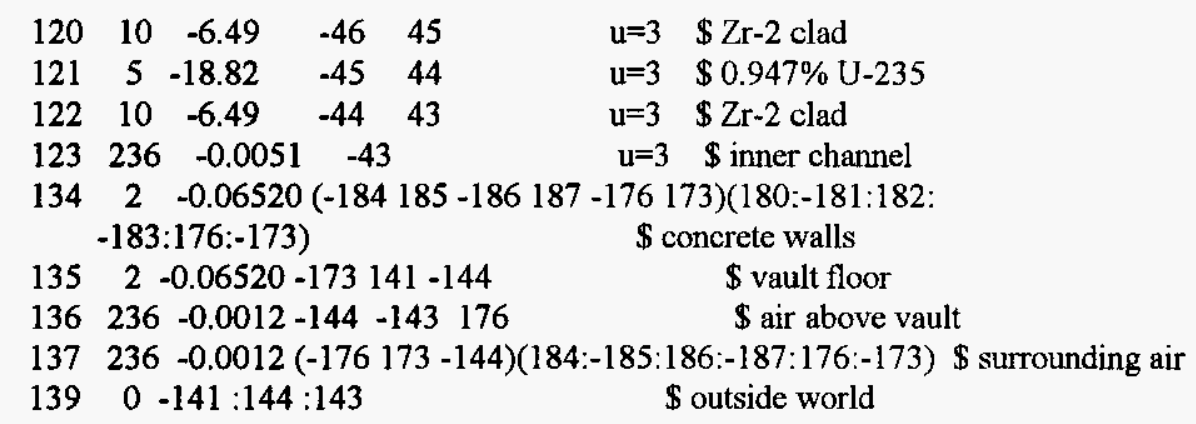

\begin{tabular}{|c|c|c|c|c|c|}
\hline 5 & $\mathrm{cz}$ & 0.6500000 & & & \\
\hline 6 & cz & 0.7107000 & & & \\
\hline 11 & $\mathrm{p}$ & 0.8660254 & -0.5000000 & 0.0000000 & 1.2013000 \\
\hline 12 & $\mathrm{p}$ & 0.8660254 & -0.5000000 & 0.0000000 & -1.2013000 \\
\hline 13 & $\mathrm{p}$ & 0.8660254 & 0.5000000 & 0.0000000 & 1.2013000 \\
\hline 14 & $\mathrm{p}$ & 0.8660254 & 0.5000000 & 0.0000000 & -1.2013000 \\
\hline 15 & py & 1.2013000 & & & \\
\hline 16 & py & -1.2013000 & & & \\
\hline 17 & $\mathrm{p}$ & 0.86602540 & $-0.5 \quad 0.0$ & 3.556 & \\
\hline 18 & $\mathrm{p}$ & 0.86602540 & $\begin{array}{ll}-0.5 & 0.0\end{array}$ & -3.556 & \\
\hline 19 & $\mathrm{p}$ & 0.86602540 & $0.5 \quad 0.0$ & 3.556 & \\
\hline 20 & $\mathrm{p}$ & 0.86602540 & $0.5 \quad 0.0$ & -3.556 & \\
\hline 21 & py & & 3.556 & & \\
\hline 22 & py & & -3.556 & & \\
\hline 43 & cz & 0.5588 & $\$$ inner chan & nnel & \\
\hline 44 & cz & 0.6223 & $\$ \mathrm{Zr}-2$ clad & & \\
\hline 45 & cz & 1.4808 & $\$$ fuel & & \\
\hline 46 & cZ & 1.5824 & $\$ \mathrm{Zr}-2$ clad & & \\
\hline 47 & $c z$ & 2.2441 & $\$$ middle ch & lannel & \\
\hline 48 & cz & 2.3076 & $\$ \mathrm{Zr}-2$ clad & & \\
\hline 49 & cz & 2.9896 & $\$$ fuel & & \\
\hline 50 & cz & 3.0531 & $\$ \mathrm{Zr}-2 \mathrm{clad}$ & & \\
\hline 122 & $\mathrm{pz}$ & 0.0000000 & & & \\
\hline 123 & $\mathrm{pz}$ & 53.086000 & & & \\
\hline 125 & $c z$ & 28.416250 & & & \\
\hline 126 & cz & 28.733750 & & & \\
\hline 127 & cz & 2.2225000 & & & \\
\hline 128 & cz & 8.4140000 & & & \\
\hline 141 & pz & -195.58800 & & & \\
\hline 143 & $\mathrm{pz}$ & 2000.00000 & & & \\
\hline 144 & cz & 3000.0000 & & & \\
\hline 146 & pz & -3.1750000 & & & \\
\hline 148 & $\mathrm{pz}$ & 49.719800 & & & \\
\hline 149 & pz & 55.808880 & & & \\
\hline 150 & pz & 353.90328 & & & \\
\hline 151 & pz & 357.71328 & & & \\
\hline 152 & $\mathrm{pz}$ & 350.72828 & & & \\
\hline $\mathrm{MCO}$ & & & & & \\
\hline 160 & cz & 29.2100 & & & \\
\hline 161 & cz & 30.4800 & & & \\
\hline 164 & pz & -8.2804 & & & \\
\hline 165 & pz & 375.000 & & & \\
\hline 166 & pz & 398.1196 & & & \\
\hline
\end{tabular}


c storage tubes

$\begin{array}{lll}170 & \text { cz } & 35.56 \\ 171 & \text { cz } & 36.83 \\ 172 & \text { pz } & -79.375 \\ 173 & \text { pz } & -81.915 \\ 174 & \text { pz } & 443.8396 \\ 175 & \text { pz } & 850.2391 \\ 176 & \text { pz } & 1205.230 \\ \text { c tube array boundaries } \\ 180 & \text { px } & 800.000 \\ 181 & \text { px } & -750.000 \\ 182 & \text { py } & 1400.00 \\ 183 & \text { py } & -1500.00 \\ \text { c concrete walls } \\ 184 & \text { px } & 891.44 \\ 185 & \text { px } & -841.44 \\ 186 & \text { py } & 1491.44 \\ 187 & \text { py } & -1591.44\end{array}$

c csb hex element

\begin{tabular}{lllllr}
190 & px & \multicolumn{2}{l}{68.0800} & & \\
191 & px & \multicolumn{2}{l}{-68.0800} & & \\
192 & p & 0.5 & 0.8660254 & 0.0 & 71.12 \\
193 & p & 0.5 & 0.8660254 & 0.0 & -71.12 \\
194 & p & -0.5 & 0.8660254 & 0.0 & 71.12 \\
195 & p & -0.5 & 0.8660254 & 0.0 & -71.12
\end{tabular}

$\begin{array}{llll}\operatorname{tr} 2 & 0.00 & 0.00 & 58.98388 \\ \text { tr3 } & 0.00 & 0.00 & 117.96776 \\ \text { tr4 } & 0.00 & 0.00 & 176.95164 \\ \text { tr5 } & 0.00 & 0.00 & 235.93552 \\ \text { tr6 } & 0.00 & 0.00 & 294.91940 \\ \text { tr7 } & 0.00 & 0.00 & 452.12000\end{array}$

mode $\mathbf{n}$

$\begin{array}{lrllll}\text { m4 } & 92235.50 & -0.01250 & 92238.50 & -0.98750 & \text { \$ outer fuel } \\ \text { m5 } & 92235.50 & -0.00947 & 92238.50 & -0.99053 & \text { \$ inner fuel } \\ \text { m236 } & 1001.50 \mathrm{c} 0.666700 & 0.6016 .50 \mathrm{c} 0.333300 & \text { \$ water }\end{array}$

$\begin{array}{ll}\mathrm{m} 236 & 1001.50 \mathrm{c} 0.6667008016 .50 \mathrm{c} 0.333300 \quad \text { \& zirc clad } \\ \mathrm{m} 1040000.50 \mathrm{c}-1.000000 & \end{array}$

m20 26000.55c 67.970001 24000.50c 20.000000 28000.50c 10.000000 \$steel $25055.50 \mathrm{c} 2.0000006000 .50 \mathrm{c} 0.030000$

m2 $1001.50 \quad 0.0642008016 .50 \quad 0.59160014000 .50 \quad 0.240500 \quad \$$ concrete $20000.50 \quad 0.07380026000 .550 .029900$

m3 $1001.50 \mathrm{c} 0.6667008016 .50 \mathrm{c} 0.333300 \quad$ \$ air space

imp:n $\quad 1.00000 \quad 60 \mathrm{r} \quad 0.00000 \$ 5,139$

$\mathrm{mt236}$ lwtr.01t

$\mathrm{mt3}$ lwtr.01t

mt2 lwtr.01t

print 406080100110126

prdmp j 300

kcode 20001.20500

ksrc 9.7 0. 20. 9.7 9.7 75. -9.79 .7130 .0$

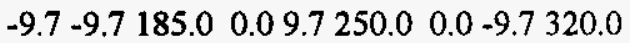

9.7 0. 470. $9.79 .7525 .-9.79 .7580 .0$

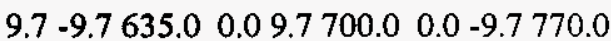




\section{F.11 AN MCO IN THE SAMPLING/WELD STATION}

Basic model for MCO loaded with 2 scrap baskets and 3 fuel baskets. Each scrap

c basket filled with Mk 4 scrap, drained MCO, no process tube in the

c scrap baskets. Revised $1.25^{\prime \prime}$ basket base plates for all baskets.

c Partially loaded fuel baskets, inner only in location 4,5

c MCO in the CSB sample or weld pit flooded with glycol

c fuel basket containing intact fuel assemblies

$\begin{array}{lllllllllll}2 & 0 & -17 & 18 & -19 & 20 & -21 & 22 & u=8 & \text { lat }=2\end{array}$ fill $=-5: 5 \quad-5: 5 \quad 0: 0$

$\begin{array}{lllllllllllll}2 & 2 & 2 & 2 & 2 & 2 & 2 & 2 & 2 & 2 & 2 & \$ 1\end{array}$

$\begin{array}{lllllllllllll}2 & 2 & 2 & 2 & 2 & 2 & 3 & 3 & 3 & 2 & 2 & \$ 2 & 2\end{array}$

$\begin{array}{lllllllllllll}2 & 2 & 2 & 2 & 3 & 3 & 3 & 3 & 3 & 3 & 2 & \$ & 3\end{array}$

$\begin{array}{lllllllllllll}2 & 2 & 2 & 3 & 15 & 3 & 3 & 3 & 3 & 3 & 2 & \$ 4 & 4\end{array}$

$\begin{array}{llllllllllll}2 & 2 & 3 & 3 & 3 & 3 & 3 & 3 & 3 & 3 & 2 & \$ 5\end{array}$

$\begin{array}{lllllllllllll}2 & 2 & 3 & 3 & 3 & 2 & 3 & 3 & 3 & 2 & 2 & \$ 6 \text { level } 1\end{array}$

$\begin{array}{lllllllllllll}2 & 3 & 3 & 3 & 3 & 3 & 3 & 3 & 3 & 2 & 2 & \$ 7\end{array}$

$\begin{array}{lllllllllllll}2 & 3 & 3 & 3 & 3 & 3 & 3 & 3 & 2 & 2 & 2 & \$ 8\end{array}$

$\begin{array}{lllllllllllll}2 & 3 & 3 & 3 & 3 & 3 & 3 & 2 & 2 & 2 & 2 & \$ 9 & 9\end{array}$

$\begin{array}{llllllllllll}2 & 2 & 3 & 3 & 3 & 2 & 2 & 2 & 2 & 2 & 2 & \$ 10\end{array}$

$\begin{array}{lllllllllllll}2 & 2 & 2 & 2 & 2 & 2 & 2 & 2 & 2 & 2 & 2 & \$ 11\end{array}$

$\begin{array}{lllllllllllll}\text { c } & & 1 & 2 & 3 & 4 & 5 & 6 & 7 & 8 & 9 & 10 & 11\end{array}$

c Mark 4 scrap optimized lattice

$50 \quad-11 \quad 12-13 \quad 14-1516$ fill=4 $u=1$ lat=2 $\$$ scrap hex

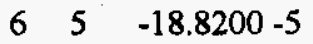

$\begin{array}{llll}7 & 10 & -6.490005-6\end{array}$

$\mathrm{u}=4 \quad \$$ scrap pin

$\mathrm{u}=4 \quad \$$ scrap clad

$8236-0.005106$

$\mathrm{u}=4 \quad \$$ scrap cell

c Scrap basket

\begin{tabular}{|c|c|c|c|c|}
\hline 9 & -125122 & & fill $=1 \quad u=9$ & $\$$ scrap in basket \\
\hline 11236 & -0.0051 & $-127-122$ & $u=9$ & $\$$ pipe interior \\
\hline 20 & -8.03 & $-122 \div 127$ & $u=9$ & $\$$ basket base \\
\hline 1420 & -8.03 & $125 \quad 122$ & $u=9$ & $\$$ basket side \\
\hline
\end{tabular}

c fictitious water cell for fuel basket lattice

$\begin{array}{lllll}24 & 236 & -0.0051 & -144 \quad \mathrm{u}=2 \quad \$ \text { fictitious cl }\end{array}$

c fuel basket

$\begin{array}{llllllll}25 & 20 & -8.03 & -128 & 127 & 122 & -123\end{array}$

$\begin{array}{llllll}26 & 236 & -0.0051 & -127 & -123\end{array}$

$\begin{array}{llllll}27 & 20 & -8.03 & -122 & 127 & -130\end{array}$

$\begin{array}{llllll}28 & 20 & -8.03 & -128 & 127 & 123\end{array}$

$\begin{array}{lllll}29 & 236 & -0.0051 & -127 & 123\end{array}$

$\begin{array}{lllll}31 & 236 & -0.0051 & -129 & 128\end{array}$

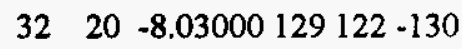

123

$\mathrm{u}=7 \quad \$$ tube wall

$\mathrm{u}=7 \quad \$$ central tube

$\mathrm{u}=7 \quad \$$ bottom plate

$\mathrm{u}=7 \quad \$$ tube wall

$u=7 \quad \$$ central tube

$\mathrm{u}=7 \quad \$$ above fuel

$\mathrm{u}=7 \quad \$$ fuel basket side

$33 \quad 0 \quad-129122128-123$

$34 \quad 236-0.0051130$

c fuel and scrap basket stack

$51 \quad 0 \quad-149 \quad$ fill=9 $u=11 \quad \$$ bottom scrap basket

$52 \quad 0 \quad 146-149 \# 51 \quad$ trcl=2 fill=7 $\quad \mathrm{u}=11 \quad$ \& fuel basket

$53 \quad 0 \quad 146 \quad-149$ \#52 trcl=3 fill=7 u=11 \$ fuel basket

$54 \quad 0 \quad 146-149 \quad \# 53 \quad$ trcl=4 fill=7 $\quad u=11 \quad \$$ fuel basket

$55 \quad 0 \quad 146-149 \# 54 \quad$ trcl=5 fill $=9 \quad \mathrm{u}=11 \quad \$$ top scrap basket

$\begin{array}{llllll}59 & 236 & -1.000 & 152\end{array}$ \#55 u=11 \$ above top basket

c $\mathrm{MCO}$ and baskets

$600 \quad(-160146-150) \quad$ fill $=11 \quad u=12 \quad \$$ interior 


$$
\begin{array}{lccccc}
61 & 20 & -8.03 & 160 & -161 & 146 \\
62 & 236 & -0.0012 & 161 & -162 & 146 \\
63 & 20 & -8.03 & 162 & -167 & 146 \\
64 & 20 & -8.03 & -167 & 169 & -146 \\
65 & 20 & -8.03 & -160 & 165 & \\
66 & 20 & -8.03 & -160 & 150 & -151 \\
67 & 236 & -0.0051 & -160 & 151 & -165 \\
68 & 0 & 164 & -163 & -166 \\
70 & 240 & -1.0327 & 167 & -168 & 169 \\
71 & 20 & -8.03 & 168 & 169 \\
72 & 20 & -8.03 & & -169
\end{array}
$$

\begin{tabular}{|c|c|c|c|c|}
\hline 115 & 236 & -0.0051 & & 50 \\
\hline 116 & 10 & -6.49 & -50 & 49 \\
\hline 117 & 5 & -18.82 & -49 & 48 \\
\hline 118 & 10 & -6.49 & -48 & 47 \\
\hline 119 & 236 & -0.0051 & -47 & 46 \\
\hline 120 & 10 & -6.49 & -46 & 45 \\
\hline 121 & 5 & -18.82 & -45 & 44 \\
\hline 122 & 10 & -6.49 & -44 & 43 \\
\hline 123 & 236 & -0.0051 & -43 & \\
\hline 135 & 2 & 0.06520 & -164 & $141-144$ \\
\hline 136 & 236 & $-0.0012-$ & $144-$ & $143 \quad 166$ \\
\hline 137 & 236 & $-0.0012-$ & 1661 & $63164-144$ \\
\hline 13 & $0-$ & $-141: 144$ : & 143 & \\
\hline
\end{tabular}

\begin{tabular}{|c|c|c|c|c|c|}
\hline 5 & $\mathrm{cz}$ & 0.8000000 & & & \\
\hline 6 & $\mathrm{cz}$ & 0.8572000 & & & \\
\hline 11 & p & 0.8660254 & -0.5000000 & 0.0000000 & 1.3992000 \\
\hline 12 & $\mathbf{p}$ & 0.8660254 & -0.5000000 & 0.0000000 & -1.3992000 \\
\hline 13 & p & 0.8660254 & 0.5000000 & 0.0000000 & 1.3992000 \\
\hline 14 & $\mathrm{p}$ & 0.8660254 & 0.5000000 & 0.0000000 & -1.3992000 \\
\hline 15 & py & 1.3992000 & & & \\
\hline 16 & py & -1.3992000 & & & \\
\hline 17 & p & 0.86602540 & $\begin{array}{ll}-0.5 & 0.0\end{array}$ & 3.4925 & \\
\hline 18 & p & 0.86602540 & $\begin{array}{ll}-0.5 & 0.0\end{array}$ & -3.4925 & \\
\hline 19 & p & 0.86602540 & $\begin{array}{ll}0.5 & 0.0\end{array}$ & 3.4925 & \\
\hline 20 & $\mathrm{p}$ & 0.86602540 & $0.5 \quad 0.0$ & -3.4925 & \\
\hline 21 & py & & 3.4925 & & \\
\hline 22 & py & & -3.4925 & & \\
\hline 43 & cz & 0.6095 & $\$ \mathrm{H} 2 \mathrm{O}$ & & \\
\hline 44 & cz & 0.6605 & $\$ \mathrm{Zr}-2$ clad & & \\
\hline 45 & cz & 1.5480 & $\$$ fuel & & \\
\hline 46 & cz & 1.6245 & $\$ \mathrm{Zr}-2$ clad & & \\
\hline 47 & cz & 2.1605 & $\$ \mathrm{H} 2 \mathrm{O}$ & & \\
\hline 48 & cz & 2.2110 & $\$ \mathrm{Zr}-2$ clad & & \\
\hline 49 & cz & 3.0165 & $\$$ fuel & & \\
\hline 50 & cz & 3.0800 & $\$ \mathrm{Zr}-2 \mathrm{clad}$ & & \\
\hline
\end{tabular}

c Mk4 inner fuel structure

$\begin{array}{lclll}80 & 236 & -0.0051 & & 46 \\ 81 & 10 & -6.49 & -46 & 45 \\ 82 & 5 & -18.82 & -45 & 44 \\ 83 & 10 & -6.49 & -44 & 43 \\ 84 & 236 & -0.0051 & -43 & \end{array}$

c Mk4 intact fuel structure

$\mathrm{u}=12 \quad \$$ MCO shell

$\mathrm{u}=12 \quad \$$ cask annulus

$\mathrm{u}=12 \quad \$$ cask

$\mathrm{u}=12 \quad \$$ cask bottom

$\mathrm{u}=12 \$$ mco top

$\mathrm{u}=12 \quad \$$ filter guard $\mathrm{u}=12 \$$ top gap

fill=12 \$ mco cask

$\mathrm{u}=12 \$$ cooling cavity

$\mathrm{u}=12$ \$ shield

$\mathrm{u}=12 \$$ cell bottom

$\mathrm{u}=15 \quad \$$ between fuels

$\mathrm{u}=15 \quad \$ \mathrm{Zr}-2$ clad

$\mathrm{u}=15 \quad \$ 0.947 \% \mathrm{U}-235$

$\mathrm{u}=15 \quad \$ \mathrm{Zr}-2 \mathrm{clad}$

$\mathrm{u}=15 \$ \mathrm{H} 2 \mathrm{O}$

$\mathrm{u}=3 \quad \$$ between fuels

$\mathrm{u}=3 \quad \$ \mathrm{Zr}-2 \mathrm{clad}$

$\mathrm{u}=3 \quad \$ 0.947 \% \mathrm{U}-235$

$\mathrm{u}=3 \quad \$ \mathrm{Zr}-2$ clad

$\mathrm{u}=3 \quad \$ \mathrm{H} 2 \mathrm{O}$

$\mathrm{u}=3 \quad \$ \mathrm{Zr}-2 \mathrm{clad}$

$\mathrm{u}=3 \quad \$ 0.947 \% \mathrm{U}-235$

$\mathrm{u}=3 \quad \$ \mathrm{Zr}-2 \mathrm{clad}$

$\mathrm{u}=3 \quad \$ \mathrm{H} 2 \mathrm{O}$

$\$$ basin floor

$\$$ space above $\mathrm{MCO}$

$\$$ surrounding space

$\$$ outside world

MCO
ing space




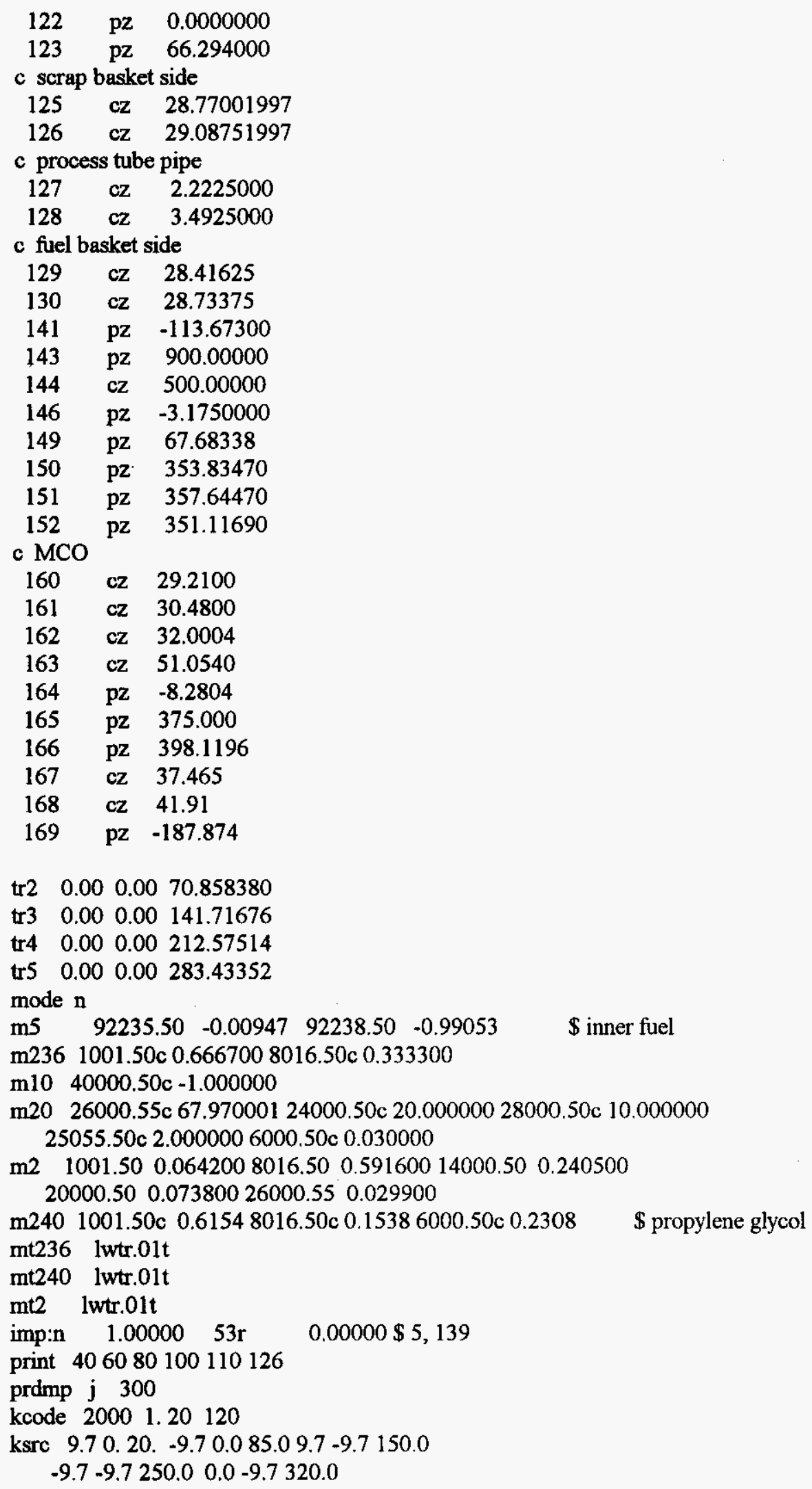




\section{F.12 AN MCO IN THE MHM}

Basic model for MCO loaded with 2 scrap baskets and 4 fuel baskets. Each scrap c basket filled with $575 \mathrm{~kg} \mathrm{Mk} 1 \mathrm{~A}$ scrap, drained $\mathrm{MCO}$ in the MHM

c fuel baskets full. Revised center post ID

c empty location 4,5

c flooded fuel and scrap baskets

c fuel basket containing intact fuel assemblies

$\begin{array}{lllllllllll}2 & 0 & -17 & 18 & -19 & 20 & -21 & 22 & u=8 & \text { lat }=2\end{array}$ fill $=-5: 5 \quad-5: 5 \quad 0: 0$

$\begin{array}{lllllllllllll}2 & 2 & 2 & 2 & 2 & 2 & 2 & 2 & 2 & 2 & 2 & \$ 1\end{array}$

$\begin{array}{lllllllllllll}2 & 2 & 2 & 2 & 2 & 2 & 3 & 3 & 3 & 2 & 2 & \$ & 2\end{array}$

$\begin{array}{lllllllllllll}2 & 2 & 2 & 2 & 3 & 3 & 3 & 3 & 3 & 3 & 2 & \$ 3 & 3\end{array}$

$\begin{array}{lllllllllllll}2 & 2 & 2 & 3 & 2 & 3 & 3 & 3 & 3 & 3 & 2 & \$ & 4\end{array}$

$\begin{array}{lllllllllllll}2 & 2 & 3 & 3 & 3 & 2 & 2 & 3 & 3 & 3 & 2 & \$ 5 & 5\end{array}$

$\begin{array}{lllllllllllll}2 & 2 & 3 & 3 & 2 & 2 & 2 & 3 & 3 & 2 & 2 & \$ 6 \text { level } 1\end{array}$

$\begin{array}{lllllllllllll}2 & 3 & 3 & 3 & 2 & 2 & 3 & 3 & 3 & 2 & 2 & \$ 7\end{array}$

$\begin{array}{lllllllllllll}2 & 3 & 3 & 3 & 3 & 3 & 3 & 3 & 2 & 2 & 2 & \$ 8\end{array}$

$\begin{array}{lllllllllllll}2 & 3 & 3 & 3 & 3 & 3 & 3 & 2 & 2 & 2 & 2 & \$ 9\end{array}$

$\begin{array}{llllllllllll}2 & 2 & 3 & 3 & 3 & 2 & 2 & 2 & 2 & 2 & 2 & \$ 10\end{array}$

$\begin{array}{lllllllllllll}2 & 2 & 2 & 2 & 2 & 2 & 2 & 2 & 2 & 2 & 2 & \$ 11\end{array}$

$\begin{array}{lllllllllllll}c & & 1 & 2 & 3 & 4 & 5 & 6 & 7 & 8 & 9 & 10 & 11\end{array}$

c Mark 1A scrap optimized lattice

$50 \quad-11 \quad 12-13 \quad 14-15 \quad 16$ fill=4 $u=1$ lat=2 $\$$ scrap hex

$\begin{array}{lll}6 & 4 & -18.8200-5\end{array}$

$\begin{array}{lll}7 & 10 & -6.490005-6\end{array}$

$\mathrm{u}=4 \quad \$$ scrap pin

$8236-0.005106$

$\mathrm{u}=4 \quad \$$ scrap clad

$\mathrm{u}=4 \quad \$$ scrap cell

c Scrap basket

$9 \quad 0 \quad-125 \quad 122 \quad 128-148 \quad$ fill=1 $u=9 \quad \$$ scrap in basket

$\begin{array}{llllllll}10 & 236 & -0.00510 & 148 & -125 & 128 & u=9 & \$ \text { space above scrap }\end{array}$

$\begin{array}{lllll}11 & 236 & -0.0051 & -127 \quad \mathrm{u}=9 \quad \text { \$ pipe interior }\end{array}$

$\begin{array}{lllllll}12 & 20 & -8.03 & 127 & -128 & 122 & u=9\end{array} \quad \$$ pipe wall

$\begin{array}{lllllll}13 & 20 & -8.03 & -122 & 127 & -126 & u=9\end{array}$ \$ basket base

$\begin{array}{llllllll}14 & 20 & -8.03 & 125 & 122 & -126 & u=9 & \$ \text { basket side }\end{array}$

$\begin{array}{llllll}15 & 236 & -0.0051 & 126 & \mathrm{u}=9 & \text { \$ outside basket }\end{array}$

c fictitious water cell for fuel basket lattice

$\begin{array}{lllll}24 & 236 & -0.0051 & -144 & u=2\end{array} \quad$ fictitious cl

c fuel basket

$\begin{array}{lllllllll}25 & 20 & -8.03 & -128 & 127 & 122 & -123 \quad u=7 & \$ \text { tube wall }\end{array}$

$\begin{array}{llllll}26 & 236 & -0.0051 & -127 & -123 & \mathrm{u}=7\end{array}$ \$ central tube

$\begin{array}{llllllll}27 & 20 & -8.03 & -122 & 127 & -126 & \mathrm{u}=7 & \$ \text { bottom plate }\end{array}$

$\begin{array}{llllllll}28 & 20 & -8.03 & -128 & 127 & 123 & \mathrm{u}=7 & \$ \text { tube wall }\end{array}$

$\begin{array}{lllllll}29 & 236 & -0.0051 & -127 & 123 & u=7 & \$ \text { central tube }\end{array}$

$\begin{array}{lllllllll}31 & 236 & -0.0051 & -125 & 128 & 123 & \mathrm{u}=7 & \$ \text { above fuel }\end{array}$

$\begin{array}{lllllll}32 & 20 & -8.03000 & 125 & 122 & -126 & \mathrm{u}=7\end{array} \quad \$$ fuel basket side

$33 \quad 0-125122128-123 \quad$ fill=8 $u=7 \quad \$$ fuel in basket

$\begin{array}{lllll}34 & 236 & -0.0051 & 126 & u=7\end{array}$ \$ outside basket

c fuel and scrap basket stack

$\begin{array}{llllll}51 & 0 & -149 & \text { fill=9 } & \mathrm{u}=11 \quad \$ \text { bottom scrap basket }\end{array}$

$52 \quad 0 \quad 146-149 \# 51 \quad$ trcl=2 fill=7 $u=11 \quad \$$ fuel basket

$53 \quad 0 \quad 146 \quad-149 \# 52 \quad$ trcl=3 fill=7 $\quad \mathrm{u}=11 \quad \$$ fuel basket

$54 \quad 0 \quad 146-149 \# 53 \quad$ trcl=4 fill=7 $\quad \mathrm{u}=11 \quad \$$ fuel basket

$55 \quad 0 \quad 146-149 \# 54 \quad$ trcl=5 fill=7 $u=11 \quad \$$ fuel basket 


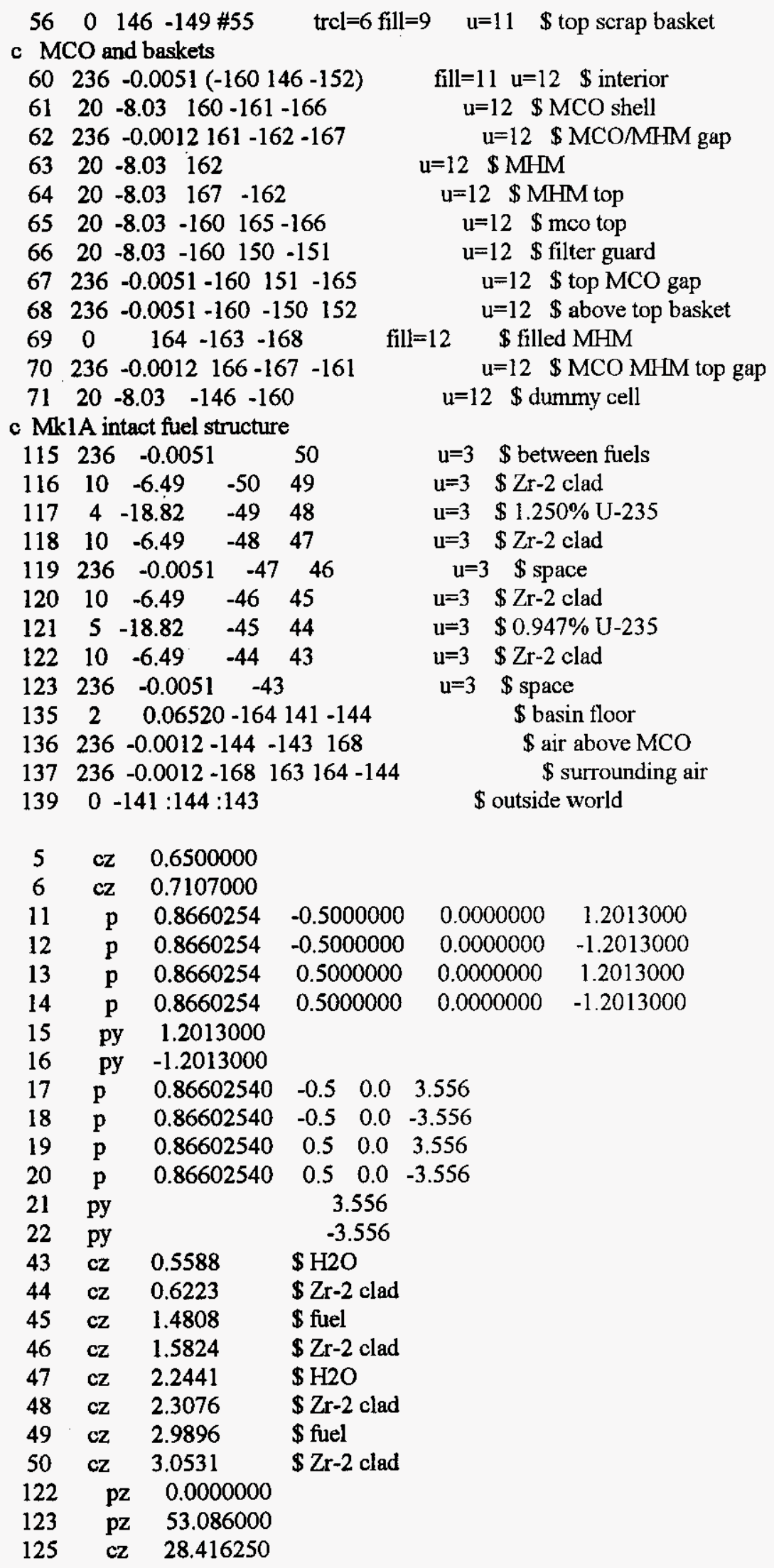


HNF-SD-SNF-CSER-005 REV 5

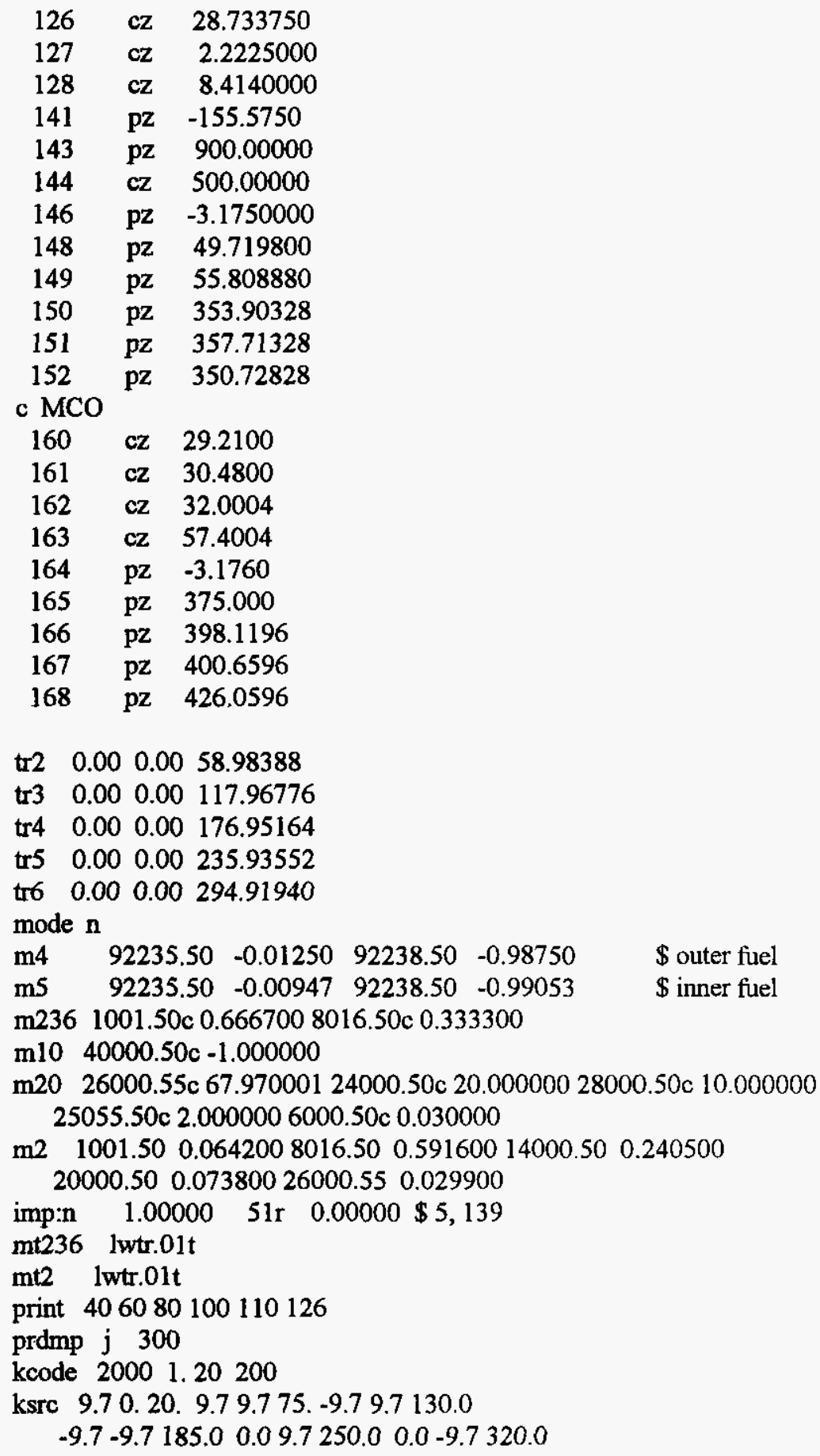

